Organizadores

Breno Trajano de Almeida Rosana de Oliveira Sá

\title{
Discursos Interdisciplinares \\ por uma Educação Transformadora
}


Breno Trajano de Almeida

Rosana de Oliveira Sá

\section{Discursos Interdisciplinares por uma Educação Transformadora}


Copyright $\odot 2020$

TODOS OS DIREITOS RESERVADOS À FACULDADE METROPOLITANA NORTE RIO-GRANDENSE - FAMEN. De acordo com a Lei n. 9.610, de 19/2/1998, nenhuma parte deste livro pode ser fotocopiada, gravada, reproduzida ou armazenada num sistema de recuperação de informações ou transmitida sob qualquer forma ou por qualquer meio eletrônico ou mecânico sem o prévio consentimento do detentor dos direitos autorais. O conteúdo desta publicação é de inteira responsabilidade dos autores.

Projeto Gráfico: Faculdade Metropolitana Norte Rio-grandense - FAMEN

Editoração Eletrônica: Alexsandra Santana dos Santos Melo.

Design de Capa e Diagramação: Daniel Aguiar da Silva Oliveira Carvalho.

\author{
Conselho Editorial \\ Prof. Manuel Tavares, \\ Prof. ${ }^{a}$ Dr. ${ }^{a}$ Antônia Dalva França Carvalho \\ Prof. ${ }^{a}$ Dr. ${ }^{a}$ Karla Cristina Silva Sousa, \\ Prof. ${ }^{a}$ Dr. ${ }^{a}$ Márcia Adelino da Silva Dias \\ Prof. Dr. Adir Luiz Ferreira \\ Prof. ${ }^{\text {a }}$ Dr. ${ }^{\text {a }}$ Elda Silva do Nascimento Melo \\ Prof. ${ }^{a}$ Dr. ${ }^{\text {a }}$ Leila Salim Leal \\ Prof. ${ }^{a}$ Dr. ${ }^{a}$ Christiane Mylena Tavares de Menezes Gameleira \\ Prof. ${ }^{a}$ Dr. ${ }^{a}$ Giovana Carla Cardoso Amorim, \\ Prof. Dr. José Rodolfo Lopes de Paiva Cavalcanti, \\ Prof. ${ }^{a}$ Dr. ${ }^{a}$ Kadydja Karla Nascimento Chagas \\ Prof. Dr. Avelino de Lima Neto \\ Prof. Dr. Sérgio Luiz Bezerra Trindade \\ Prof. Dr. Eduardo Henrique Cunha de Farias \\ Prof. Dr. João Maria de Lima \\ Editores-chefes \\ Prof. ${ }^{a}$ Dr. ${ }^{a}$ Andrezza M. B. do N. Tavares. \\ Prof. Dr. Fábio Alexandre Araújo dos Santos \\ Catalogação da Publicação na Fonte / \\ Bibliotecária Alexsandra Santana dos Santos Melo CRB-15/530
}

D611 Discursos Interdisciplinares por uma Educação Transformadora /

Breno Trajano de Almeida, Rosana de Oliveira Sá. - Natal:

Editora FAMEN, 2020.

205 p.

ISBN 978-65-87028-01-9

DOI https://doi.org/10.36470/famen.2020.14

1. Educação. 2. Discursos Interdisciplinares. 3. Transformação na Educação. 4. Aprendizagem. 5. Estratégia de aprendizagem. I. - Almeida, Breno Trajano de. II. - Sá, Rosana de Oliveira. Org. III. Título.

CDU 37

FACULDADE METROPOLITANA NORTE RIO-GRANDENSE - FAMEN

Rua São Severino, 18 - Bom Pastor, Natal - RN, 59060-040

(84) 3653-6770. 
Sempre acreditei que após mais de oitenta anos de vida e bem mais de duzentos livros publicados no Brasil e traduzidos para outras línguas, nada mais de novo, em Educação, seria possível esperar. Estava errado!

Recebi os originais da obra "Discursos interdisciplinares por uma educação transformadora" de um coletivo de professores e, ao ler os seus pensamentos e conclusões, assim como um velho marinheiro que se encanta ao descobrir terras novas, me renovei com as ideias e ideais compartilhados. Foi maravilhoso degustar das novas aprendizagens adquiridas com a riqueza das afirmações presentes neste $e$-book, plenas de sabedoria.

A convicção da importância desse trabalho se apoia em três fundamentos. O primeiro é que, quanto mais autores se debruçam sobre temas diversos, maior a oportunidade de produção de conhecimento. O segundo fundamento é que os assuntos abordados se justificam porque todos os autores vislumbram a educação como uma ferramenta essencial e alavanca imprescindível para o futuro do país. E, finalmente, o terceiro e o mais importante fundamento é que o presente $e$-book propõe práticas e ações para a educação dentro e fora da escola.

Mas, com tantos especialistas com perfis tão diversificados, não seria este um trabalho ambicioso? A resposta é afirmativa. Ambicioso não porque define, mas sugere; não porque aponta soluções, mas estimula a reflexão.

Prefaciar este livro não representa mero gesto de cortesia, mas saborosa sensação de deslumbramento. Aos autores, para além dos elogios, os meus sinceros agradecimentos e votos por novas e auspiciosas aventuras e descobertas criativas.

Com admiração e irrestrita sinceridade,

\section{Celso Antunes}

Mestre em Educação pela Universidade de São Paulo (USP) Membro da Associação Internacional pelos Direitos da Criança Brincar (UNESCO) Autor de livros na área de Educação 


\section{Apresentação}

O e-book "Discursos interdisciplinares por uma educação transformadora" ressalta o valor das dinâmicas de práxis interdisciplinares em espaços escolares e não escolares. Propõe a superação de dispositivos de manipulação, como ocorre na transmissão cumulativa da educação conservadora, em detrimento da formação para o pensamento crítico, a curiosidade e a diversidade. Interdisciplinaridade e pensamento integrador são ideias presentes nos capítulos. Estes conceitos pedagógicos propõem a eliminação da separação artificial do conhecimento em áreas disciplinares estanques com base no pressuposto do desenvolvimento humano que requer amplitude do pensamento.

De forma orquestrada, os capítulos do livro - cada um ao seu modo e de acordo com a dinâmica de cada área - revelam pesquisas e relatos de experiências em diferentes espaços de aprendizagem do Brasil. Ademais, defendem a educação para além do enciclopedismo; a educação impulsionadora da dinâmica social renovadora, descentralizada, democrática e participativa; assim como, valorizam a sociedade plural construída e ressignificada a partir da diversidade socioeconômica e dos conhecimentos advindos de vivências além dos muros escolares.

Os capítulos também apontam para a interdisciplinaridade como abordagem integradora que permite a formação do discente, a partir da reflexão sobre temas e problemas cotidianos de sua vida social e profissional, visando motivar os docentes para o ensino por meio de práticas pedagógicas que proporcionem o pleno exercício da cidadania, bem como coloquem o discente como protagonista do processo de ensino e aprendizagem. Nesta direção, corrobora o pensamento da educação transformadora, que possibilita adquirir saberes para se humanizar, emancipar, libertar (FREIRE, 1974; 1996); que privilegia formas inovadoras de conexão de conhecimentos contextualizados, em oposição à mera transmissão alienadora de dados e informações descontextualizadas.

No que concerne à estruturação, este $e$-book apresenta temáticas que abordam: a formação de professores e práxis pedagógicas; política e gestão da educação; ensino e currículo; psicologia da educação, psicopedagogia, neuropedagogia e inclusão escolar. Percorre diferentes níveis e modalidades de ensino, isto é, lugares de atuação do professor: contexto de Educação de Jovens e Adultos; de Ensino Médio; de Ensino Superior; de Educação Especial; e de Formação Docente. Toda essa diversidade de 


\section{Apresentação}

temáticas, práticas e atores dão materialidade às reflexões, descrições e avaliações de diferentes metodologias que envolvem o processo de ensino e aprendizagem dentro e fora dos ambientes educacionais.

No tocante aos autores deste $e$-book, além da motivação individual de divulgar suas pesquisas, têm o interesse coletivo de apresentar caminhos que promovam uma educação de qualidade para os discentes em formação, assim como disseminar ações didáticas exitosas que possam servir aos mais variados contextos de aprendizado.

Boa leitura!

\section{Breno Trajano de Almeida}

\section{Rosana de Oliveira Sá}


1

Percepções sobre os desafios da docência e atuação dos estudantes como gestores da aprendizagem: um estudo de caso

Rebeca Sá do Nascimento Carrazzoni e Patrícia Lacerda de Carvalho

Juventude, drogas e racismo: redução de danos e combate ao
genocídio da juventude negra

Francisco José Pires

3

Utilização de modelos táteis sustentáveis como alternativa no ensino

de Química para alunos com deficiência visual

Leonardo Rafael Medeiros

O canto coral como contribuição na formação humana no IFRN: um relato dos Campi Ipanguaçu e Nova Cruz

Artur Fabiano Araújo de Albuquerque e Luciana Real Limeira

Educação e saúde: práxis de aprendizagem no ambiente escolar

Francisco Marcos da Silva Figueiredo e Hellyegenes de Oliveira

Maria José Rocha Lima

O exercício da cidadania na sociedade Brasileira: reflexão a partir

das ocupações das escolas estaduais Paulistas em 2015

Roseli Trevisan Marques de Souza

Experiências de formação docente em contextos socioculturais

diversos a partir da obra de Teresa Vergani

Louize Gabriela Silva de Souza 
Edna Oliveira da Paz

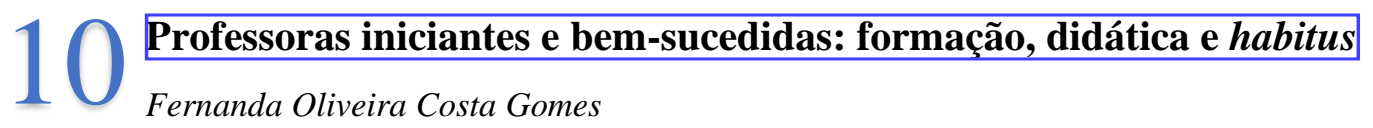

Fernanda Oliveira Costa Gomes

\section{Psicometria: limitações e avanços}

12 Recursos didáticos: conceito e implicações pedagógicas no processo de ensino-aprendizagem

Tuesla Bezerra Santos, Karina de Oliveira Lima e Kleber Kroll de Azevedo Silva

13

O processo da formação de professores em Educação Especial e a práxis pedagógica no atual contexto educacional brasileiro

Hellyegenes de Oliveira e Francisco Marcos da Silva Figueiredo

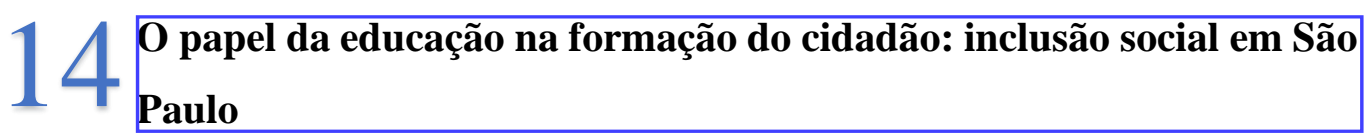

Francisco José Pires

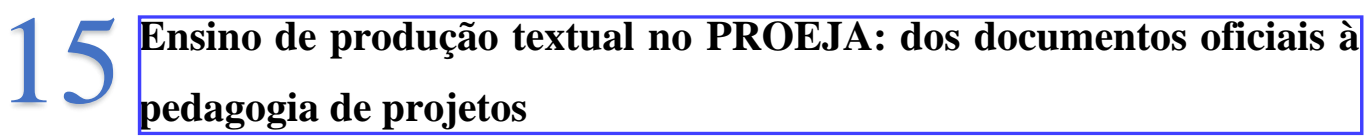

Rosana de Oliveira Sá e Linduarte Pereira Rodrigues

$16 \begin{aligned} & \text { Os Institutos Federais e o direito à Educação Especial no Ensino } \\ & \text { Superior }\end{aligned}$ 


\title{
PERCEPÇÕES SOBRE OS DESAFIOS DA DOCÊNCIA E ATUAÇÃO DOS ESTUDANTES COMO GESTORES DA APRENDIZAGEM: UM ESTUDO DE CASO
}

\author{
Rebeca Sá do Nascimento Carrazzoni ${ }^{1}$ \\ Patrícia Lacerda de Carvalho ${ }^{2}$
}

\begin{abstract}
RESUMO
A educação no Ensino Superior enfrenta novos formatos que conferem novos papéis para os atores envolvidos no processo de ensino-aprendizagem, o docente e o discente. Assumir os desafios enfrentados, transformando a postura da educação tradicional passiva pela postura ativa na busca pelo conhecimento, autonomia e protagonismo do aprendiz tornou-se uma discussão recorrente no ambiente educacional. Sendo assim, este capítulo se propôs a analisar o papel desempenhado pelo docente e pelo discente na nova configuração do ensino superior, a partir da aplicação da metodologia ativa Caso para Ensino para 32 alunos do curso de Administração. A pesquisa aplicada de abordagem qualitativa utilizou a observação participante e o estudo de caso único para analisar o contexto. $\mathrm{O}$ caso para ensino foi o método para identificar as possibilidades das metodologias ativas na transformação do conhecimento. O relato da experiência, a reflexão crítica sobre os papéis assumidos e a aprendizagem na ação foram pautas da análise. Conclui-se que a educação mudou e os papéis também mudaram, sendo necessária uma nova configuração na educação superior, cuja sugestão do capítulo enfatiza as metodologias de ensino como caminho aplicável.
\end{abstract}

Palavras-chave: Docência. Aprendizagem. Metodologias Ativas. Caso para Ensino.

\section{INTRODUÇÃO}

O conhecimento é um aspecto imprescindível para o desenvolvimento humano e da sociedade. As formas de adquirir o conhecimento foram se transformando ao longo da história a partir da evolução das interações e interesses dos seres humanos. Essas modificações, cada vez mais ágeis e impactantes, geram obsolescência de estruturas e sistemáticas comumente utilizadas, mudando assim, o modo de aprender. Nesse contexto, o conhecimento não é algo estático, mas dinâmico, que atualmente vem exigindo competências dos professores e alunos para que o ambiente educacional seja criativo, inovador e promova a colaboração para resultar no aprendizado (BITTENCOURT, 2016).

O debate atual acerca da educação superior em conjunto com o ambiente educacional levanta questões importantes, já que é sabido que o mercado de trabalho exige uma postura ativa e dinâmica dos profissionais, orientados para as constantes mudanças e disposição para

\footnotetext{
${ }^{1}$ Mestra e Doutoranda em Administração no Programa de Pós-Graduação em Administração da UFPB. E-mail: rebecasa.nascimento@gmail.com

${ }^{2}$ Mestra e Doutoranda em Administração no Programa de Pós-Graduação em Administração da UFPB. E-mail: patricialacerdac@gmail.com
} 
buscar o aprendizado continuamente. Dessa forma, torna-se incoerente o conteúdo engessado baseado na tradicionalidade. Isto conduz o ensino a integração do aprofundamento técnicocientífico e teórico com a prática e aprendizagem dinâmica, preparando o aluno para situações reais após a formação (ESCRIVÃO FILHO; RIBEIRO, 2008).

Diante das novas exigências da educação, questiona-se o papel do professor e do aluno, ambos com suas novas funções ante aos novos formatos de discussão dos saberes para sedimentação do conhecimento. A visão antiga de que o professor é o centro da sala, colocado em um degrau acima porque é detentor do conhecimento, perde espaço para a desafiadora percepção de que os alunos possuem uma atuação ativa e autônoma para proporcionar seu próprio aprendizado, sendo este mediado pela experiência (ARAÚJO et al., 2014).

O ensino superior demanda uma preparação do docente, muitas vezes, ausente nas formações de pós-graduação, a didática e o contato com novas metodologias de ensino exigem um esforço pessoal deste profissional. Buscar aliar a teoria e prática é um assunto recorrente que, segundo Araújo et al. (2014), está sujeito à premissa de um aprendizado direcionado ao processo experiencial e a ação na formação docente. Ademais, os autores ressaltam a importância de estratégias de ensino que estimulem o ambiente propício ao pensamento reflexivo e senso crítico para a evolução dos conhecimentos e aprendizagem.

Com base no exposto, o capítulo se propõe a analisar o papel desempenhado pelo docente e pelo discente na nova configuração do ensino superior, a partir da aplicação da metodologia ativa Caso para Ensino. Diversos estudos demonstram essas ressignificações no modo de ensinar e aprender, novos papéis dos atores e resultados melhores (SONAGLIO; GODOI; LIMA; SILVA, 2013; ARAÚJO, 2014; BITTENCOURT, 2016; SALVADOR; IKEDA, 2019).

\section{ENSINO SUPERIOR: OS PAPÉIS ASSUMIDOS}

O ambiente da docência é desafiador, nesse sentido o professor precisa estar atendo às mudanças na sociedade, tanto em dimensões técnicas como humanas, visando estar apto a construir conhecimento em cada circunstância que a profissão irá lhe exigir, visto que atualmente a ênfase está na formação permanente com o foco no ensino-aprendizagem do aluno.

Em se tratando de ensino, o centro é o docente, já na aprendizagem o centro é o aluno. Diante disso, busca-se que não exista um "centro", mas sim que ambos atuem como coautores na construção do ensino-aprendizagem. Dessa forma, o docente deixa de centralizar e transmitir as informações que os alunos devem conhecer para tornar-se um elemento que contribui para a construção do conhecimento. 
Segundo Bittencourt (2016), o ensino superior sustentou a tradicionalidade do conhecimento dissociado da realidade mercadológica por muito tempo. Nesse contexto, "em quatro situações são perceptíveis as mudanças no ensino superior: no processo de ensino, no incentivo à pesquisa, na parceria e coparticipação entre professor e aluno no processo de aprendizagem, e no perfil docente. Assim, se exige cada vez mais do docente. A competência pedagógica do docente de ensino superior transcorre pela formação simultânea com o mundo do trabalho, teoria e a prática, com o objetivo de fazer da sala de aula um ambiente vivo e real (MASETTO, 2012, p. 23).

A educação se transformou por meio do emprego de diferenciadas técnicas e metodologias de ensino, divergindo do processo tradicional que preconiza a memorização. A necessidade de aulas baseadas em métodos e dinâmicas de aprendizagem distintas do modelo de aulas expositivas e passivas demanda do docente e do discente uma nova postura frente ao conhecimento, a partir de processos de ensino-aprendizagem mais colaborativos, reflexivos, críticos, criativos e inovadores (BITTENCOURT, 2016; SALVADOR; IKEDA, 2019).

O espaço educacional exige que o docente detenha competência na área do conhecimento que leciona, domínio na área pedagógica, propriedade na área política, desenvolvimento de habilidades na área afetivo-emocional e, ainda, habilidades humanas e profissionais. Sendo assim, “o ofício do professor só acontece quando exercemos nossa docência com profissionalismo, isto é, de forma competente e cidadã" (GAETA; MASETTO, 2013, p. 103).

Nesse contexto, Masetto (2012, p. 55) apresenta quatro integrantes do processo de aprendizagem no ensino superior: "os professores, os alunos, o monitor e a direção". O professor pode atuar de várias maneiras no processo, unindo-se a seus pares, objetivando dar maior significado aos assuntos selecionados a serem ministrados em determinada disciplina, observando o que os alunos já tiveram oportunidade de estudar, priorizando os assuntos que serão novidades para turma, mesclando assuntos de várias disciplinas que se complementam, ajudando em um melhor entendimento, entre outros mecanismos. Enfim, o professor exerce um papel de ponte entre o aprendiz e o aprendizado, operando como mediador pedagógico, trabalhando junto com os alunos.

O monitor vem fortalecer a interação "professor - aluno" e "aluno - professor", sendo um importante colaborador para o diálogo existente entre as partes e atuando como um facilitador na disciplina em questão. O aluno vem atuar na interaprendizagem, sendo fundamental nesse processo. Muitos alunos têm dificuldade de aprender com o professor e aprendem com os colegas, por meio de atividades em grupo ou grupos de estudos. 
Por fim, a direção, que atua apoiando, possibilitando recursos e cobrando resultados dos outros participantes, buscando gerenciar se o processo de aprendizagem de fato está acontecendo, geralmente por meio de indicadores como nota, avaliação dos professores, necessidades dos alunos, entre outros. Sendo importante destacar que existem outros participantes nesse processo, como: servidores técnicos, colaboradores, entre outros.

De fato, a educação dinâmica e inovadora mostra-se necessária para o aprendizado e desenvolvimento de capacidades e habilidades. Segundo Bittencourt (2016), a aprendizagem ativa acompanha a rapidez das mudanças na sociedade do conhecimento e refere-se ao processo de análise, síntese e solução de problemas para gerar conhecimento ativamente de forma colaborativa. Esse tipo de envolvimento é proporcionado por atividades experimentais, solução de problemáticas, colaboração e aprendizagem experiencial.

\section{APRENDIZAGEM EXPERIENCIAL: CASO PARA ENSINO COM METODOLOGIA ATIVA}

Existem pessoas que se sentem mais produtivas observando, enquanto outras preferem teorizar e/ou experimentar, o que define os estilos de aprendizagem individuais. Entretanto, esse processo de seleção pode ocorrer com o docente que acaba priorizando o estilo de sua preferência. No entanto, ao focalizar em um único método específico de aprendizagem, o docente não é capaz de atuar como facilitador para os aprendizes. Faz-se necessário compreender as múltiplas linguagens utilizadas para alcançar a utilização das distintas metodologias disponíveis para contribuir para o aprendizado efetivo. Desse modo, o docente poderá, verdadeiramente, assumir o papel de mediador e aprendiz no processo, colaborando com a aprendizagem de forma direta.

Ressalta-se que o processo de aprendizagem precisa dos múltiplos fatores para se concretizar, a exemplo do planejamento, atuação, postura, empatia e colaboração, que são etapas essenciais para construção do alicerce da aprendizagem. Portanto, torna-se fundamental conhecer e compreender quais as metodologias ativas de ensino e como se aplicam, conforme elencadas no Quadro 1.

Quadro 1 - Exemplos de Metodologias Ativas e suas características

\begin{tabular}{|c|l|c|}
\hline $\begin{array}{c}\text { Metodologias } \\
\text { Ativas }\end{array}$ & \multicolumn{1}{c|}{ Características das Metodologias Ativas } & Referências \\
\hline $\begin{array}{c}\text { Aprendizagem } \\
\text { baseada em } \\
\text { problemas }\end{array}$ & $\begin{array}{l}\text { Pressupõe a cooperação em pequenos grupos, conduzida } \\
\text { por um tutor, com um estudo autodirigido, para } \\
\text { proporcionar uma educação multidisciplinar e } \\
\text { avaliações progressivas. }\end{array}$ & $\begin{array}{c}\text { Neto, } \text { et al. } \\
(2017)\end{array}$ \\
\hline Casos para ensino & $\begin{array}{l}\text { Abrange um relato de uma situação vivenciada por um } \\
\text { profissional, uma organização, ou ainda um projeto }\end{array}$ & $\begin{array}{c}\text { Alberton e } \\
\text { Silva (2018) }\end{array}$ \\
\hline
\end{tabular}




\begin{tabular}{|c|c|c|}
\hline & $\begin{array}{l}\text { específico de natureza prática e/ou social, que apresenta } \\
\text { um dilema a ser analisado no contexto do ensino. }\end{array}$ & \\
\hline Estudo de caso & $\begin{array}{l}\text { Os estudantes aprendem à medida que analisam as } \\
\text { situações apresentadas nos casos e desenvolvem um } \\
\text { plano de ação para resolver as causas fundamentais dos } \\
\text { problemas expostos. }\end{array}$ & $\begin{array}{l}\text { Machado e } \\
\text { Callado } \\
\text { (2008) }\end{array}$ \\
\hline Estudo dirigido & $\begin{array}{l}\text { Tem como enfoque a participação ativa dos alunos, tais } \\
\text { como: leitura, interpretação, comparação, avaliação, } \\
\text { análise e elaboração de textos construídos a partir do } \\
\text { contexto estudantil. }\end{array}$ & $\begin{array}{l}\text { Gabriel, Silva } \\
\text { e Freire } \\
\text { (2018) }\end{array}$ \\
\hline $\begin{array}{l}\text { Estudo do } \\
\text { meio/campo }\end{array}$ & $\begin{array}{l}\text { Consiste no estudo direto do contexto natural e social no } \\
\text { qual o aluno se insere. Auxilia na realidade, observação } \\
\text { e comunicação, como também ressalta uma realidade } \\
\text { para além da sala de aula. }\end{array}$ & $\begin{array}{l}\text { Lestinge e } \\
\text { Sorrentino } \\
\quad(2008)\end{array}$ \\
\hline Estudo do texto & $\begin{array}{l}\text { Como desenvolver? Análise textual; Análise Temática; } \\
\text { Análise Interpretativa; Problematização; ou, Síntese } \\
\text { (reelaboração da mensagem com base na reflexão } \\
\text { pessoal). }\end{array}$ & $\begin{array}{l}\text { Gabriel, Silva } \\
\text { e Freire } \\
\text { (2018) }\end{array}$ \\
\hline $\begin{array}{l}\text { Explosão de } \\
\text { ideias } \\
\text { (brainstorming) }\end{array}$ & $\begin{array}{l}\text { Técnica de geração de ideias, que pode ser utilizada de } \\
\text { uma maneira disciplinada de geração de novas ideias a } \\
\text { partir de discussão entre os participantes; onde a } \\
\text { liberdade é dada a todos os integrantes do grupo. }\end{array}$ & $\begin{array}{l}\text { Tobias, } \\
\text { Faleiro e } \\
\text { Mello Braga } \\
\text { (2017) }\end{array}$ \\
\hline Fórum & $\begin{array}{l}\text { Debate livre de ideias, apresentações esquematizadas, } \\
\text { presença de um coordenador/moderador cuja parte final } \\
\text { é a das perguntas. O Fórum promove construções } \\
\text { colaborativas com valorização da subjetividade no } \\
\text { diálogo efetivado. }\end{array}$ & $\begin{array}{l}\text { Gonçalves, } \\
\text { Cunha e Sales } \\
\quad(2016)\end{array}$ \\
\hline $\begin{array}{l}\text { História em } \\
\text { quadrinho }\end{array}$ & $\begin{array}{l}\text { Os processos de codificação e decodificação que os } \\
\text { alunos experimentam na criação e interpretação de } \\
\text { quadrinhos se tornam elementos facilitadores do } \\
\text { aprendizado, porque há uma necessidade de } \\
\text { concentração. }\end{array}$ & $\begin{array}{l}\text { Silva, Santos } \\
\text { e Bispo } \\
\text { (2017) }\end{array}$ \\
\hline Júri simulado & $\begin{array}{l}\text { Apresenta-se com o formato de uma sessão do tribunal } \\
\text { de júri, com algumas adaptações para o desenvolvimento } \\
\text { enquanto atividade pedagógica de forma que favoreça o } \\
\text { entendimento dos alunos e o desenvolvimento da } \\
\text { argumentação no aluno. }\end{array}$ & $\begin{array}{l}\text { Real e } \\
\text { Menezes } \\
(2007)\end{array}$ \\
\hline Mapa conceitual & $\begin{array}{l}\text { Ampliam a possibilidade de os estudantes se valerem de } \\
\text { recursos pessoais favoráveis para refletir e compreender } \\
\text { seus percursos de aprendizagem. }\end{array}$ & $\begin{array}{c}\text { Souza e } \\
\text { Burochovitch } \\
(2010)\end{array}$ \\
\hline Música & $\begin{array}{l}\text { Esse recurso implica considerar aspectos como a letra, a } \\
\text { melodia, o estilo, o ritmo, o volume, entre outros. A } \\
\text { música pode provocar a imaginação, a reflexão, } \\
\text { associações, pensamentos metafóricos. }\end{array}$ & $\begin{array}{l}\text { Vergara } \\
(2003)\end{array}$ \\
\hline $\begin{array}{l}\text { Produção de } \\
\text { vídeo-aula }\end{array}$ & $\begin{array}{l}\text { Os vídeos pedagógicos atraem os alunos, aproximando a } \\
\text { sala de aula do cotidiano e das linguagens de } \\
\text { aprendizado e comunicação da sociedade. A produção } \\
\text { de vídeos é uma ótima forma de expressão e } \\
\text { comunicação. }\end{array}$ & $\begin{array}{l}\text { Silva e } \\
\text { Oliveira } \\
(2018)\end{array}$ \\
\hline $\begin{array}{l}\text { Seminário } \\
\text { dinâmico }\end{array}$ & $\begin{array}{l}\text { Seminário em que todos os alunos se envolvem visando } \\
\text { oportunizar o desenvolvimento de vários papéis, como } \\
\text { avaliador, questionador, crítico, apresentador, entre } \\
\text { outros. }\end{array}$ & $\begin{array}{l}\text { Santos, Bastos } \\
\text { e Coelho } \\
\text { (2016) }\end{array}$ \\
\hline Stop motion & $\begin{array}{l}\text { Técnica de animação na qual o animador trabalha } \\
\text { fotografando objetos, fotograma por fotograma, em } \\
\text { outras palavras quadro a quadro. Entre um fotograma e } \\
\text { outro, o animador muda a posição do objeto, da forma } \\
\text { mais minuciosa possível, para que o filme nos dê a ilusão } \\
\text { de que o objeto está se movimento. }\end{array}$ & $\begin{array}{l}\text { Kaminski } \\
(2010)\end{array}$ \\
\hline
\end{tabular}

Fonte: Elaborado pelas autoras. 
A discussão a respeito da aprendizagem deriva de diversas correntes filosóficas com bases ontológicas e epistemológicas distintas, demonstrando a construção do seu conhecimento. A aprendizagem experiencial se direciona a implantar na educação tradicional os dados práticos da profissão, ultrapassando o sentido do "aprender fazendo" para enfatizar a utilização de processos cognitivos, motivacionais e emocionais, no qual os alunos executam atividades reflexivas sobre o que estão realizando e que tenha significado (BITTENCOURT, 2016).

Para o autor supracitado, a visão da aprendizagem ativa envolve o processo de ensino centrado na aprendizagem, métodos ativos para proporcionar a prática, transformação no papel assumido pelo docente e pelo discente, a metacognição e autorregulação da aprendizagem e a autonomia. Nesse contexto, a aprendizagem experiencial está inserida na aprendizagem ativa como um braço de suas possibilidades.

De acordo com Kolb (1984, p.41), a aprendizagem experiencial se refere ao "processo pelo qual o conhecimento é criado através da transformação da experiência". O ambiente real é o pano de fundo para a reflexão do aprendiz sobre a situação posta, de modo que ao final o mesmo tenha gerado experiências e significados emancipatórios. Com base nisso, a aprendizagem em ação preconiza o livre engajamento no delineamento de soluções de problemas instigantes que não possuem decisões programadas, propiciando o desenvolvimento pessoal por meio do processo reflexivo sobre a ação (O’NEIL; MARSICK, 2007).

Desse modo, o método de caso para ensino apresenta-se como uma metodologia ativa que pode proporcionar a aprendizagem experiencial, visto que este é tido como a junção de técnicas e ferramentas para acelerar experiências e por meio de sua resolução o conhecimento é construído (ALBERTON; SILVA, 2018). De acordo com os autores, a aprendizagem experiencial para o caso para ensino ocorre pela aprendizagem em ação, auxiliando no processo educacional de gestão e promovendo as estratégias ativas para uso pelos docentes. Para Ikeda, Veludo-de-Oliveira e Campomar (2006, p. 147), método do caso "é uma estratégia de ensino baseada na apresentação de circunstâncias factíveis e/ou verídicas com o objetivo de levar os alunos a refletirem sobre decisões para o episódio estudado".

O caso para ensino constitui-se em uma descrição de uma situação gerencial detalhada que demonstra a complexidade real das organizações para posterior tomada de decisão em ambiente controlado (ALBERTON; SILVA, 2018). O dilema apresentado pelo caso promove aprendizagem a partir das discussões em colaboração em busca de uma resposta que não é 
predeterminada. De acordo com os autores, esse método enfoca em uma situação real que pode ser vivenciada na profissão, em qualquer tipo de organização.

Sendo assim, percebe-se que o método pode gerar experiências enriquecedoras para o discente permitindo o desenvolvimento por meio das decisões tomadas, interação com outros aprendizes e reflexão sobre a ação. Com isso, o processo de ensino aprendizagem é modificado por meio das transformações exigidas pelos métodos ativos, tornando o discente protagonista da construção do seu conhecimento e ressignificação dos conteúdos e conceitos a partir de uma situação real. O docente assume uma nova postura mais moderadora e a este compete o esforço de se preparar para os novos desafios.

\section{METODOLOGIA}

O trabalho caracteriza-se como uma pesquisa de natureza aplicada e abordagem qualitativa, por meio da utilização do método de observação participante e estudo de caso único (YIN, 2015), com o objetivo de analisar o papel desempenhado pelo docente e pelo discente na nova configuração do ensino.

O meio escolhido para verificação no campo constitui-se no método de caso para ensino, cujo planejamento e aplicação eram de domínio das pesquisadoras e autoras. Para tanto, foi realizada a aplicação do caso em uma turma do curso de Administração, de uma instituição privada de ensino superior em João Pessoa, na Paraíba, considerando o livre acesso às turmas devido ao vínculo de trabalho de uma das pesquisadoras.

A disciplina que serviu de campo para esta pesquisa foi a de "Empreendedorismo", no $3^{\circ}$ período do curso no ano 2018 , segundo semestre, entre os meses de agosto e dezembro e era formada por 32 discentes. A referida disciplina exigia uma visão mais ampla dos alunos quanto a organização, esclarecendo que o empreendedor necessitava treinar a sua percepção sistêmica e agir com inovação e diferenciação no mercado.

Com o intuito de operacionalizar o método, um planejamento foi elaborado por meio do plano de aula. Em seguida, de acordo com o tema específico da aula, selecionou-se um caso para ensino "CASA FLOR. UM CASO DE EMPREENDEDORISMO EM PEQUENO NEGÓCIO”, publicado na Revista de Administração e Inovação, elaborado por Souza e Fracasso (2008).

A aplicação ocorreu em um dia comum de aula, dentro do horário de duas horas, com a participação de todos os alunos por ser uma atividade avaliativa. A experiência está relatada na próxima seção com base na observação e participação das pesquisadoras e a partir dos relatos 
voluntários promulgados pelos discentes. A experiência foi gravada (com consentimento dos discentes) e revisitada para análise e descrição da aplicação do caso.

\section{DISCUSSÃO DOS RESULTADOS}

A seguir, o relato da experiência da aplicação do método de caso para ensino será descrito divido em fases, com base nas percepções das pesquisadoras participantes, destacando as interações, reflexões e ressignificação vivenciada pelos docentes e discentes no processo de ensino e aprendizagem experiencial.

\section{Fase 1 - Planejamento da aplicação do método}

Inicialmente, houve a elaboração de um plano de aula para organização da aplicação do referido caso. A distribuição do tempo e delimitação das atividades e entregas era essencial para o alcance do objetivo final. A intenção era proporcionar uma experiência que se aproximasse da realidade, promovendo a discussão dos pontos chaves e relacionando-os com a teoria discutida em sala de aula. Além disso, a reflexão deveria ser incentivada a partir da ação. $\mathrm{O}$ plano está exposto no Quadro 2.

Quadro 2-Plano de aula

\begin{tabular}{|l|}
\hline Disciplina: Empreendedorismo \\
Tema da aula: O empreendedorismo e o negócio: conceitos gerais sobre empreendedorismo \\
e empreendedor, características atitudes empreendedoras, oportunidades de \\
negócios e classificação do empreendedorismo.
\end{tabular}




\begin{tabular}{|c|c|}
\hline 30 minutos & $\begin{array}{l}\text { - Os alunos discutem em pequenos grupos de } 4 \text { alunos as suas percepções } \\
\text { quanto ao caso e a situação apresentada. }\end{array}$ \\
\hline 5 minutos & $\begin{array}{l}\text { - As professoras fazem uma análise do caso, destacando conceitos vistos } \\
\text { em sala para estimular o pensamento crítico. }\end{array}$ \\
\hline 60 minutos & $\begin{array}{l}\text { - Com base nas questões disponibilizadas e respondidas pelos alunos, as } \\
\text { professoras iniciam a discussão no grande grupo. Na mesma posição na } \\
\text { qual se encontravam em grupo, é solicitado que os mesmos expliquem o } \\
\text { que observaram no grupo, se houve divergências e quais as opiniões. } \\
\text { - As professoras procuram não responder nada e pedir que os próprios } \\
\text { alunos discutam as visões dos colegas. }\end{array}$ \\
\hline 15 minutos & $\begin{array}{l}\text { - Fechamento da discussão, relacionando as observações com a teoria; } \\
\text { - Percepção e opinião dos alunos quanto a aplicação e aprendizagem. }\end{array}$ \\
\hline \multicolumn{2}{|l|}{ 3. Conteúdo } \\
\hline \multicolumn{2}{|c|}{$\begin{array}{l}\text { 1. Empreendedorismo: conceitos gerais, configurações e tipos; } \\
\text { 2. Empreendedor: conceitos, características e comportamento; }\end{array}$} \\
\hline \multicolumn{2}{|c|}{ 4. Avaliação da aprendizagem } \\
\hline \multicolumn{2}{|c|}{$\begin{array}{l}\text { Instrumento } \\
\text { - } \quad \text { Caso para ensino; } \\
\text { - } \quad \text { Folha de respostas. }\end{array}$} \\
\hline \multicolumn{2}{|c|}{ 5. $\quad$ Recursos Didáticos } \\
\hline \multicolumn{2}{|c|}{$\begin{array}{l}\text { - Folhas de resposta; } \\
\text { - Lápis para quadro branco e apagador; }\end{array}$} \\
\hline \multicolumn{2}{|c|}{ 6. Referências } \\
\hline \multicolumn{2}{|c|}{$\begin{array}{l}\text { DORNELAS, J. C. A. Empreendedorismo: Transformando Ideias em Negócios. } 2 \text { ed. Rio de } \\
\text { Janeiro: Campus, } 2014 . \\
\text { SCHNEIDER, Elton Ivan. A caminhada empreendedora: a jornada de transformação de } \\
\text { sonhos em realidade. Editora Curitiba: InterSaberes, } 2012 \text {. }\end{array}$} \\
\hline
\end{tabular}

Fonte: Elaborado pelas autoras, 2018.

Orientadas pelo plano, as pesquisadoras buscaram por casos que expressassem o conteúdo de maneira clara e objetiva, retratando-o com base em uma situação problema factível e solucionável pelos alunos.

Para a escolha do caso Casa Flor, em análise, percebeu-se que este era escrito em forma de diálogo, mas também apresenta seções de explicação e descrição. Faz-se importante destacar a facilidade da leitura e número de páginas suficiente e adequado (pontos destacados como positivo pelos alunos). A preocupação com receptividade do caso era persistente devido ao fato de ser a primeira experiência dos alunos com aquela metodologia, portanto a intenção era de compreensão e estímulo à discussão.

Nesse sentido, o dilema a ser resolvido pelos alunos era claro, a trama simples e de fácil entendimento proporcionaria uma associação instantânea com os temas abordados. O interesse foi concretizado ao perceber as possibilidades que o caso dispunha, pois em suas entrelinhas existiam escolhas que levariam a rumos diferentes e isso poderia gerar discussões mais ricas e não programadas.

Para ser um bom caso, Alberton e Silva (2018) explicam que é necessário que as notas de ensino devem estar bem estruturadas de modo a orientar o professor na condução. A crítica 
está nesse ponto, tendo em vista que as notas de ensino eram pouco instrutivas de modo que as discussões não eram aprofundadas e direcionadas a reflexão. Além disso, as questões muito simples e mal formuladas foi um ponto, posteriormente, destacado pelos próprios alunos. Apesar da constatação prévia da fragilidade das questões, as mesmas foram testadas e atestouse que deveriam ser reformuladas, mas isso foi positivo na experiência considerando que provocou uma reflexão nos alunos ao ler e compreender o contexto do caso.

Enquanto papel assumido pelo professor, as pesquisadoras se prepararam para serem mediadoras da experiência e estimular a reflexão por meio de perguntas e não respostas. Assim, o caso fio repassado e segmentado com pontos importantes, momentos de intervenção e questões provocativas em torno da discussão embasadas na teoria.

\section{Fase 2 - Preparação dos discentes}

A preparação se inicia nas duas aulas que antecedem a aplicação do caso. Primeiramente, a sensibilização dos alunos é uma fase primordial para entusiasmá-los e esclarecer que será uma dinâmica diferente que necessita da participação ativa de todos. Nesse momento, a necessidade de leitura é enfatizada, destacando que é preciso que estejam aptos a compartilharem suas opiniões e criticidade quanto a situação apresentada.

O caso foi disponibilizado com antecedência de 15 dias para conclusão da leitura e reflexão das respostas. Aos alunos era solicitado que respondessem, individualmente, as 6 questões propostas pelas autoras do caso e as levassem respondidas no dia da aplicação. Na semana seguinte, que antecedia a aplicação do caso, foi explicada a dinâmica do método com explanações sobre a participação e pontuações associadas ao desempenho. Nesse momento, foi acordado que a atividade seria gravada para análise da aplicação da metodologia, cuja aceitação foi unânime.

\section{Fase 3 - A aplicação do caso}

No dia da aplicação, as pesquisadoras foram previamente a sala para preparar o local para interação e, após distribuir as cadeiras em grupos de 4 alunos, a entrada foi liberada. Os alunos foram divididos por numeração, com o intuito de separar os grupos de afinidades naturalmente formados. Os alunos se mostraram eufóricos e ansiosos para compartilhar suas respostas. Dessa forma, o plano de aula foi seguido à risca em tempo e em ações.

O papel a ser assumido aparece nesse momento, quando o aluno se torna protagonista da sua experiência, decide quando e como interagir e explicar aos demais o seu ponto de vista. A observação era primordial nesse momento, pois eles conversavam e refletiam sobre a 
percepção diferente de seus colegas. Alguns tentavam indagar as professoras sobre a dúvida, mas as pesquisadoras não se pronunciavam quanto a resposta, apenas contribuíam com outra pergunta ou direcionando a fala para outro aluno presente no mesmo grupo. Em alguns momentos, os alunos diziam que iriam mudar suas respostas (o que era permitido), visto que haviam compreendido de outra maneira após a discussão com o grupo.

Nesse contexto, vale ressaltar que a pergunta mais recorrente foi " $\mathrm{O}$ empreendedorismo contido no caso é por necessidade e ou por oportunidade?". Posteriormente a aplicação do caso, essa pergunta foi respondida por eles quando compreenderam que os conceitos existem para refletirmos, mas que na realidade do empreendedor as "caixinhas" que sistematizam o conteúdo podem se misturar e demostrar a real situação do momento, podendo esta ser diferente da situação do momento seguinte. Essa ressignificação foi concluída pelos alunos, sem intervenção, apenas mediação da distribuição de falas entre eles.

O aprendizado é perceptível, por vezes parece que o tempo é curto, mas é suficiente para consolidar a reflexão na ação e gerar estímulo para novas descobertas. O procedimento foi operacionalizado, sendo 30 minutos no pequeno grupo de 4 alunos, em seguida as pesquisadoras professoras explanaram pontos primordiais no caso em consonância com a teoria e, por fim, 60 minutos de discussão com toda a turma em um grande círculo. As pesquisadoras mediavam as discussões e davam a palavra para os alunos, pois alguns participavam mais.

Um episódio em especial merece ser destacado, um aluno compreendeu que uma personagem (a mãe) era causadora da desistência das protagonistas (as filhas), sendo isso contrário ao caso. Como o aluno vinha participando da discussão, compreendeu-se que houve uma assimilação errada por parte dele. Entretanto, as professoras pesquisadoras não precisaram interferir porque os próprios alunos começaram a dizer passagens do caso (sem estarem com ele impresso) que atestavam que a participação da personagem (mãe) não era primordial para a ação, mas era um apoio emocional e financeiro que não tinha poder de decisão. Isso comprovou que a metodologia proporciona o desenvolvimento dos alunos e a posição ativa diante de situações.

Ademais, o entusiasmo dos alunos para responderem aos questionamentos e, em alguns casos, as colocações tão estruturadas envolvidas em teorias fizeram com que as pesquisadoras percebessem que, enquanto professoras, por vezes, podem subestimar o potencial e a capacidade de atuar enquanto protagonista do seu próprio conhecimento devido à visão tradicional da educação passiva. Isso se deu em decorrência da ativa participação e agradecimentos pela experiência de aprendizado e colaboração, bem como pela compreensão da teoria em situações reais (ressignificação dos seus conhecimentos). 
O docente se depara com uma nova configuração, um novo local e uma nova maneira de agir, exigindo preparação e disposição para permanecer na metodologia. A mediação não desmerece o professor, enaltece sua condição de facilitador e o protagonismo do aluno necessários para construções mais efetivas dos saberes. A sensação sentida pelas professoras foi de transformação na educação e coerência com as novas necessidades da educação superior.

Ao final da experiência, os alunos pediram para compartilhar sua percepção sobre o método de caso para ensino. Eles relataram que o fato de poder vivenciar a experiência por meio do caso, os proporcionou uma visão mais ampla do que havia sido discutido em sala, além disso, explicaram que a mistura entre os colegas tinha sido muito interessante, pois puderam ver outras opiniões e se integrarem mais. De fato, os alunos relataram que mudaram suas opiniões a partir das visões dos colegas e dos questionamentos provocativos ditos pelas professoras pesquisadoras, enfim, afirmaram que se fossem responder novamente as 6 questões, responderiam de maneira diferente baseados em seus conhecimentos construídos de forma ativa e reflexiva.

A partir da aplicação do caso, as professoras pesquisadoras perceberam que são as condutoras das experiências dos alunos, mas que não possuem o controle sobre a reação de cada um deles. Nesse caso, a orientação para a autonomia e a postura ativa contribuem mais significativamente do que o derramamento desenfreado de conteúdos em caixinhas, o contato com a realidade transforma a experiência do docente e do discente, gerando um processo de ensino-aprendizagem mais efetivo. Fazendo mister destacar que, na experiência no ensino superior, uns três alunos foram embora, sendo necessária a reflexão: "Será que os discentes estão abertos para metodologias ativas de aprendizagem?".

\section{CONSIDERAÇÕES FINAIS}

Este capítulo se propôs a analisar o papel desempenhado pelo docente e pelo discente na nova configuração do Ensino Superior, a partir da aplicação da metodologia ativa Caso para Ensino, em uma instituição privada de ensino superior, no curso de graduação em Administração, dentro da disciplina de Empreendedorismo. Buscou-se fomentar uma reflexão crítica a respeito dos papéis assumidos, da ressignificação do conhecimento e da receptividade da experiência como prática de ensino no nível superior.

A urgência da transformação da educação superior, abandonando a exposição passiva de conteúdos engessados e assumindo a autonomia do aluno como gerador do seu conhecimento, 
é demonstrada nesse contexto analisado, a partir das experiências de aplicação de metodologias ativas de ensino.

O docente de carreira precisa enfrentar uma nova realidade de mudanças constantes e de um público discente desconectado com a tradicionalidade própria do método antigo de ensino. As novas metodologias representam a nova configuração necessária para atingir o interesse e incentivar os discentes a buscarem seu próprio aprendizado de maneira autônoma, colaborativa, criativa e efetiva, solucionando problemas, agindo a partir de desafios e refletindo para assimilação do conhecimento adquirido.

Nesse contexto, os papéis se transformam para proporcionar o ambiente adequado para geração de novas construções do saber. $\mathrm{O}$ docente assume o papel de mediador e incentivador da busca, reflexão e colaboração. O discente, por sua vez, torna-se protagonista e proporciona sua maior compreensão por meio de competências adquiridas no processo de ensinoaprendizagem.

$\mathrm{Na}$ verdade, não se deve correr na contramão do desenvolvimento. Os papéis mudam e a forma de aprender também, assim como tudo no mundo, a educação demonstra sua evolução. Cabem aos atores desse processo buscarem suas atuações e se moldarem às novas configurações, priorizando o conhecimento e a formação dos profissionais.

\section{REFERÊNCIAS}

ALBERTON, A.; SILVA, A. B. Como escrever um bom caso para ensino? Reflexões sobre o método. Revista de Administração Contemporânea, v. 22, n. 5, p. 745-761, 2018.

ARAÚJO, G. D. et al. Currículo e vínculos teoria-prática: reflexões no processo ensinoaprendizagem em um curso de graduação em Administração. Desenvolve Revista de Gestão do Unilasalle, v. 3, n. 2, p. 09-31, 2014.

BITTENCOURT, J. P. Arquiteturas pedagógicas inovadoras nos mestrados profissionais em administração. 2016. Tese (Doutorado). Universidade de São Paulo.

ESCRIVÃO FILHO, E.; RIBEIRO, L. R. C. Inovando no ensino de administração: uma experiência com a aprendizagem baseada em problemas (PBL). Cadernos EBAPE. BR, v. 6, n. SPE, p. 01-09, 2008.

FRACASSO, E. M. et al. Casa flor. Um caso de empreendedorismo em pequeno negócio. Revista de Administração e Inovação-RAI, v. 5, n. 3, 2008.

GABRIEL, A.; DA SILVA, J. S.; FREIRE, E. J. A utilização da investigação, do estudo dirigido e do estudo de texto como estratégias de ensino: um caso particular numa instituição de ensino superior (IES) no município de alta Floresta - MT. Pedagogia em Foco, v. 13, n. 9, p. 112-129, 2018. 
GAETA, C; MASETTO, M. Ofício de professor. In: . O professor iniciante no ensino superior: aprender, atuar e inovar. São Paulo: Senac São Paulo, 2013.

GONÇALVES, A. J.; CUNHA, J. L. L.; SALES, G. L. Concepção do fórum p\&rlv: avaliação formativa da aprendizagem. RENOTE-Revista Novas Tecnologias na Educação, v. 14, n. 1, 2016.

IKEDA, A. A.; VELUDO DE OLIVEIRA, T. M.; CAMPOMAR, M. C. O caso como estratégia de ensino na área de Administração. Revista de Administração, v. 41, n. 2, p. 147-157, 2006.

LESTINGE, S.; SORRENTINO, M. As contribuições a partir do olhar atento: Estudos do meio e a educação para a vida. Ciência \& Educação. Brasília, DF. 14, n. 3, p. 601-19, 2008.

LIMA, T. B.; SILVA, A. B. da. Difusão das perspectivas teóricas da aprendizagem na formação de administradores. Revista Iberoamericana sobre Calidad, Eficacia y Cambio em Educación, v. 11, n. 3, p. 5-30, 2013.

MACHADO, A. G. C.; CALLADO, A. A. C. Precauções na adoção do método de estudo de caso para o ensino de administração em uma perspectiva epistemológica. Cad. EBAPE.BR, Rio de Janeiro, v. 6, n. spe, p. 01-10, ago. 2008.

MASETTO, M. T. Docência universitária com profissionalismo: Competência pedagógica do professor universitário. São Paulo: Summus, 2012, p. 23-41.

NETO, J. O. R. et al. Aprendizagem baseada em problemas: o mito e a realidade. Cadernos UniFOA, v. 6, n. 16, p. 79-84, 2017.

O'NEIL, J.; MARSICK, V. Understanding action learning. Nova York: AMACOM; Div American MgmtAssn, 2007.

REAL, L. M. C.; MENEZES, C. Júri simulado: possibilidade de construção de conhecimento a partir de interações em um grupo. In: NEVADO, R. A.; CARVALHO, M. J. S.; MENEZES, C. S. (Orgs.). Aprendizagem em rede na Educação a Distância. Porto Alegre: Ricardo Lenz, 2007.

SALVADOR, A. B.; IKEDA, A. A. O uso de metodologias ativas de aprendizagem em MBA de marketing. Cadernos EBAPE.BR, v. 17, n. 1, p. 129-143, 2019.

SANTOS, G. T.; BASTOS, A. F. V.; COELHO, A. L. A. L. Contribuições do Seminário Dinâmico no processo de aprendizagem pela ótica dos graduandos de contabilidade da UFPB. Anais. XL ANPAD, Costa do Sauipe- BA, 2016.

SILVA, A. B.; SANTOS, G. T. D.; BISPO, A. C. K. A. The Comics as Teaching Strategy in Learning of Students in an Undergraduate Management Program. Revista de Administração Mackenzie, v. 18, n. 1, p. 40-65, 2017.

SILVA, R. V.; OLIVEIRA, E. M. As possibilidades do uso do vídeo como recurso de aprendizagem de aula do $5^{\circ}$ ano. Pesquisa em educação: Desenvolvimento, ética e responsabilidade social, 2010. 
SONAGLIO, A. L. B.; GODOI, C. K.; DA SILVA, A. B. Estilos de aprendizagem experiencial e aquisição de habilidades: um estudo com discentes de graduação em administração em instituições de ensino superior. Administração: ensino e pesquisa, v. 14, n. 1, p. 123-159, 2013.

SOUZA, N. A.; BORUCHOVITCH, E. Mapas conceituais: estratégias de ensino/aprendizagem e ferramenta avaliativa. Educação em Revista, v. 26, n. 3, p. 195-218, 2010 .

TOBIAS, O. P.; FALEIRO, F. S.; DE MELLO BRAGA, L. B. Proposta de aumento da eficácia e eficiência no processo de usinagem de eixos ferroviários. Revista Petra, v. 3, n. 1, 2017.

VERGARA, S. Constant. Repensando a relação ensino aprendizagem em administração: argumentos teóricos, práticas e recursos. Organizações \& Sociedade, v. 10, n. 28, p. 131-142, 2003.

YIN, R. K. Estudo de caso: planejamento e métodos. 5. ed. Porto Alegre: Bookman, 2015. 


\title{
JUVENTUDE, DROGAS E RACISMO: REDUÇÃO DE DANOS E COMBATE AO GENOCÍDIO DA JUVENTUDE NEGRA
}

\author{
Francisco José Pires ${ }^{1}$
}

\section{RESUMO}

Este relato de experiência procura diagnosticar, analisar e vivenciar os problemas enfrentados pela Juventude negra em relação às drogas, ao racismo, à redução de danos e ao combate ao genocídio da juventude negra, como recursos didáticos pedagógicos. As Tecnologias da Informação e da Comunicação (TICs) apontam para a importância da internet, web, inteligência coletiva e blog como recursos e estratégias pedagógicas. Para efetivar a pesquisa, realizamos uma oficina com os alunos da disciplina Sociologia Jurídica, em uma comunidade da Zona Leste de São Paulo, tornando-os protagonistas, interagindo com os jovens da comunidade, no intuito de esclarecer sobre o perigo das drogas, como também para combater o racismo. A presente pesquisa culminou com um Júri Simulado em uma universidade em São Paulo. O trabalho empírico foi realizado para valorizar o ponto de vista do cidadão na avaliação dos serviços oferecidos pelos equipamentos públicos. Após as reflexões e a materialização da atividade, ficou evidente que a questão racial ainda não é encarada naturalmente pelos estudantes.

Palavras-chave: Educação. Inclusão Social. Juventude Negra. Racismo.

\section{INTRODUÇÃO}

O presente relato de experiências tem como tema Juventude, Drogas e Racismo: redução de danos e combate ao genocídio da juventude negra. Procura-se analisar a questão das condições em que vive essa população no Brasil e as políticas públicas implantadas neste contexto, que podem definir o tipo de cidadão que ocupa os espaços das grandes cidades.

As inquietações que nos impulsionaram à escolha do tema que subjaz à pesquisa provêm da constatação de que a questão das políticas públicas para redução de danos e combate ao genocídio dessa parcela da população ainda é incipiente. E as condições precárias da juventude negra se converteram, na década de 1990 e na primeira década do século XXI, em problemas emergentes carentes de soluções por parte do poder público.

Diante disso, este relato pretende levantar as políticas públicas implantadas pelo Governo brasileiro com vistas à melhoria da qualidade de vida da juventude negra, a partir de 1990, com investigação centrada nas cidades do Rio de Janeiro e de São Paulo.

As pesquisas apontam que com um processo de globalização desigual, a incerteza global torna-se ainda mais angustiante pela ausência de processos educativos e projetos sociais

\footnotetext{
1 Doutor e Mestre em Integração da América Latina, Jornalista, Geógrafo e Pedagogo. E-mail: fco.pires@hotmail.com
} 
consistentes que possam reduzir danos e qualificar o jovem negro para o exercício da cidadania e para o mercado de trabalho, atendendo a demanda educacional e profissional que se faz necessária para as exigências do mundo atual.

Nesse sentido este relato procura diagnosticar, analisar e vivenciar os problemas enfrentados pela Juventude negra em relação às drogas e ao racismo, utilizando como recurso didático- pedagógico as Tecnologias da Informação e da Comunicação (TICs), apontando a importância da internet, web, inteligência coletiva e blog, enquanto recursos e estratégias pedagógicas.

O presente trabalho objetiva: 1) estudar a qualidade de vida da juventude negra na Zona Leste da cidade de São Paulo; 2) analisar as condições e os contextos sociopolítico, econômico e cultural em que se materializam o cotidiano dos jovens negros, a partir das políticas públicas empreendidas; e 3) identificar pontos de interesses comuns para a realização de estudos conjuntos entre pesquisadores ou centros de pesquisas.

Para materializar esses objetivos, partimos de uma caracterização global dos processos de exclusão da juventude negra, ocorridos a partir dos anos 90, contextualizando as particularidades do objeto de estudo, o que contribuiu para se desenhar o perfil dos jovens negros. Além disso, foram selecionadas informações que permitem apreciar a magnitude das condições em que vive a juventude negra, o uso de drogas e o genocídio, precisando variáveis comparativas da intervenção do Estado no processo de redução de danos da juventude negra, identificando as principais limitações que levam o tratamento estatístico oficial a uma compreensão do foco deste trabalho.

Por fim, foi realizado um levantamento da produção de destaque dos últimos anos, especialmente, sem detrimento de trabalhos significativos realizados anteriormente, identificando as tendências centrais das abordagens conceituais vigentes e predominantes, pressupostos teóricos, temáticas privilegiadas, preocupações centrais e principais lacunas do conhecimento sobre o papel do Estado na redução de danos da juventude negra.

As considerações colocadas ao longo do trabalho têm seu conteúdo referenciado ao contexto brasileiro, especialmente no Rio de Janeiro e em São Paulo, no que se refere à relação entre as políticas públicas e exclusão/inclusão da juventude negra. Contudo, trata-se de um esforço de compreensão de uma temática posta para discussão, sem pretensão de esgotar o assunto, dada a abrangência e complexidade de que se reveste.

Em consequência, avançar na pesquisa sobre a relação entre políticas públicas e exclusão/inclusão da juventude negra no Rio de Janeiro e em São Paulo significa aprofundar a 
compreensão das transformações dos espaços dessas cidades, o que equivale a um melhor entendimento da organização da sociedade e de suas estruturas no passado e no presente.

Esta pesquisa é justificada pelo fato de que as produções científicas sobre a relação existente entre políticas públicas e exclusão/inclusão da juventude negra no Rio de Janeiro e em São Paulo ainda são incipientes. Interessa neste trabalho resgatar instrumentos que possam contribuir para a ciência no contexto de um mundo globalizado, uma vez que se faz necessário o registro de novas formas de atuação do Estado, considerando as transformações das relações sociais que se dão dentro de um processo global amplo, apontando processos sociais relevantes na atualidade.

Nesse sentido, pretende-se discutir questões, como: que medidas poderiam desencadear um processo de recuperação da Educação para redução de danos da juventude negra? Qual o papel das universidades no atual cenário mundial? Qual a contribuição das Tecnologias da Informação e da Comunicação na construção do conhecimento? Como perceber no processo de modernização aspectos das relações sociais capitalistas e seu impacto no conjunto da sociedade?

Com isso, pretende-se contribuir para a compreensão de como se deu a intervenção do Estado a partir dos anos 90 no Brasil, reelaborando aspectos da própria vida social. A relação políticas públicas e exclusão/inclusão da juventude negra é o paradigma com o qual se espera responder tais indagações.

Neste estudo, o relato de experiências e materializa a partir do plano de aula e do uso das ferramentas de interatividade como recursos e estratégias pedagógicas, no intuito de refletir acerca da relevância das tecnologias no processo de ensino-aprendizagem. Para tanto, foi realizada uma oficina intitulada Juventude, drogas e racismo: redução de danos e combate ao genocídio da juventude negra, com recursos didático-pedagógicos convencionais e com as Tecnologias da Informação e da Comunicação.

Busca-se, portanto, uma abordagem que considera a crise de paradigma como uma questão social, com destaque para inclusão/exclusão da Juventude negra, drogas e racismo e o papel do Estado na consecução de uma política pública que seja capaz de resolver o problema da violência urbana com a redução de danos.

\section{FUNDAMENTAÇÃO TEÓRICA}

Vale ressaltar que o período objeto desta reflexão é especialmente a década de 90 do século XX e o início do século XXI, por serem momentos em que se registram inúmeros casos 
de agressão e racismo contra a juventude negra. Ademais, apesar das políticas públicas implantadas nos últimos 12 anos, verifica-se que a exclusão social, provocada especialmente pelo racismo e pelo uso de entorpecentes, é alarmante.

Isso significa que as gestões anteriores aos anos 90 começaram em um momento ainda nebuloso, no bojo do processo de redemocratização do país, e concluíram seus governos em um contexto de redesenhar um mapa social das condições de vida da juventude negra, especialmente no Rio de Janeiro e em São Paulo. Nesses termos, os objetivos e o perfil da pesquisa foram atravessados por uma onda de transformações culturais, políticas e econômicas que será necessariamente considerada.

Rodrigues (1957, p. 35) já denunciava que,

[...] é preciso romper com os silêncios e as ausências produzidos pelo racismo brasileiro, que elege jovens negros como alvo privilegiado de suspeição e como representantes da violência, negando a esses sujeitos direitos sociais básicos e o reconhecimento da positividade e da legitimidade de suas trajetórias.

O escritor, insatisfeito com a questão da discriminação racial contra os jovens no Brasil, acrescenta:

[...] Não caçamos pretos, no meio da rua, a pauladas, como nos Estados Unidos. Mas fazemos o que talvez seja pior. A vida do preto brasileiro é toda tecida de humilhações. Nós tratamos com uma cordialidade que é o disfarce pusilânime de um desprezo que fermenta em nós, dia e noite (RODRIGUES,1957, p. 36).

Comungando com essas ideias, é possível afirmar que as políticas públicas urbanas empreendidas no Brasil em tempos de globalização aprofundam a desigualdade social, especialmente da juventude negra se comparada aos demais componentes da sociedade brasileira, pois ao mesmo tempo em que aparentemente proporciona a construção e execução de um projeto de inclusão, impulsiona verdadeiro estado de exclusão social para a maioria absoluta da população, especialmente os jovens negros.

Nesse sentido, o procedimento de identificar características das políticas públicas em relação às drogas, racismo, redução de danos e combate ao genocídio da juventude negra, recursos investidos e resultados obtidos, permite formular parâmetros de avaliação e também o estabelecimento de referenciais para padrões mínimos de investimentos.

Nessa perspectiva, busca-se identificar nas políticas públicas implantadas sobre a problemática posta para discussão, alguns indicadores que permitam medir resultados na 
melhoria da média e também na melhoria do patamar inferior da sociedade, ou seja, capacidade de promover a inclusão social.

Ao analisar a literatura sobre o racismo, observa-se que, de um modo geral, existe um ponto de convergência entre os pesquisadores, pois a maioria se preocupa em estudar os danos provocados pelo uso de drogas e o racismo contra a juventude negra. Sobre essa temática, Ribeiro (1995) afirma que:

[...] somos um povo estruturalmente marcado, portanto, por uma histórica cultura autoritária, classista e racista [...]a mais terrível de nossas heranças é esta de levar sempre conosco a cicatriz de torturador impressa na alma e pronta a explodir na brutalidade racista e classista (RIBEIRO, 1995, p.120).

Essa cultura racista e discriminatória que separa os direitos entre ricos e pobres, entre pretos e brancos aprofundando a desigualdade social é potencializada em violência, muitas vezes de maneira camuflada gerando uma grande diferença entre aparência e essência. Sobre essa questão, Odália (1993, p.22-23) enfatiza que "nem sempre a violência se apresenta como um ato, como uma relação, como um fato, que possua estrutura facilmente identificável”. E prossegue,

$\mathrm{O}$ ato violento se insinua, frequentemente, como um ato natural, cuja essência passa despercebida. Perceber um ato como violento demanda do homem um esforço para superar sua aparência de ato rotineiro, natural e como que inscrito na ordem das coisas (ODÁLIA, 1993, p.22-23).

Diante do exposto, observa-se que os danos causados pela violência, especialmente contra a juventude negra, é frequentemente camuflada, sendo revelada nas comunidades carentes na vivência cotidiana.

Ainda, vale mencionar as dificuldades enfrentadas para levantar material teórico para sobre o tema deste estudo. Tal quadro se registra, devido à escassez de publicações. $\mathrm{O}$ que se encontra com mais facilidade são os registros oficiais publicados pelas Secretarias de Estado e organismos estatais.

\section{METODOLOGIA}

A presente pesquisa define-se como um estudo de cunho qualitativo, interdisciplinar e teórico-bibliográfico como itinerário para compreender alguns problemas enfrentados pelos jovens negros. Acerca das pesquisas qualitativas, Patton (1986) explicita: 
A principal característica das pesquisas qualitativas é o fato de que estas seguem a tradição compreensiva ou interpretativa. Isto significa que essas pesquisas partem do pressuposto de que as pessoas agem em função de suas crenças, percepções, sentimentos e valores e que seu comportamento tem sempre um sentido, um significado que não se dá a conhecer de modo imediato (PATTON, 1986 apud MAZZOTTI; GEWANDSZNAJDER, 1988, p.131).

A reflexão constrói-se a partir de um trabalho de recopilação, revisão bibliográfica e análise de dados, que tomam dimensão à medida que se compara as políticas públicas implantadas na perspectiva da inclusão social da juventude negra.

Para se estabelecer estreita relação entre a teoria e a prática, assim como constatar os fatos, realizou-se uma pesquisa empírica com os alunos do curso de Direito de uma Universidade em São Paulo, na disciplina de Sociologia Jurídica, em uma comunidade da Zona Leste, na perspectiva de esclarecer a juventude que ali reside sobre o perigo das drogas e o combate ao racismo, com vistas à redução de danos e combate ao genocídio dessa população.

\section{RELATO DA EXPERIÊNCIA APLICADA}

Foram desenvolvidas duas aulas, conforme plano a seguir:

- Objetivo: Realização de uma oficina em uma comunidade, utilizando-se de diferentes ferramentas de interatividade;

- Conteúdos: Introdução e conceitos de Juventude, drogas e racismo: redução de danos e combate ao genocídio da juventude negra;

- Metodologia de Ensino: Exposição oral do tema, explicando os objetivos da atividade, métodos e avaliação. Em seguida, aula teórico-prática no laboratório de informática; aula prática na praça com uma palestra a partir de uma roda de conversa, seguida de uma oficina sobre o tema e de uma pesquisa com a juventude daquela comunidade. $\mathrm{O}$ fechamento das ações didáticas foi marcado com um Júri Simulado.

- Recursos de Apoio: Data Show, utilização da internet, vídeo, web e pesquisa em blog sobre o tema, texto de apoio.

Após uma visita técnica na comunidade, formou-se um Júri iniciado com uma discussão da situação apresentada, a saber: o caso da Joana Elisa da Silva Cesário, que se sente discriminada pelo patrão. Posta a questão para discussão, não houve consenso.

Para o Júri, os participantes da pesquisa foram divididos em 2 grupos, denominados A e B. O Grupo A defendia a ideia de ter havido discriminação, levantando a questão acerca dos patrões terem sugerido que a estagiária esticasse o cabelo. Os participantes argumentaram que 
desde a escravidão o negro sofre com a violência do preconceito; que o preconceito é uma questão ideológica, pois está arraigado na mente das pessoas desde a formação do povo brasileiro; e que os cidadãos não poupam a oportunidade de tratar o negro como inferior.

Já o Grupo B defendeu que não houve situação de preconceito, argumentando que o Colégio só estava protegendo a estagiária e que a imagem é muito importante, principalmente numa instituição na qual a relação com o público externo é direta. Segundo o grupo, a Instituição de Ensino objetivou colocá-la em uma situação de igualdade social.

Após o debate, os participantes assistiram ao vídeo "Manifesto Porta na Cara - Flagrante na agência bancária", estabelecendo uma relação entre a situação apresentada no vídeo e o contexto da realidade em que vivem os jovens negros na Zona Leste de São Paulo. Grande parte dos alunos da Universidade e os adolescentes da comunidade ficaram indignados com o pouco caso que se faz, em geral, com a situação do negro no Brasil.

Cabe registrar que a turma levou a atividade muito a sério e, em nenhum momento, houve intenção explícita de julgar, no sentido de condenar ou livrar alguém de uma situação. Foi uma atividade muito prazerosa, já que os estudantes ficaram empolgados em discutir o tema em outras aulas de Sociologia Jurídica, inclusive deram a ideia de pesquisar sobre os direitos específicos do negro no Brasil hoje e fazer um painel no Hall de entrada da Universidade, além de disponibilizar o conteúdo no blog criado para este curso. Por fim, foram selecionadas as informações e extraídas algumas conclusões para redigir o relatório final com os resultados da experiência.

\section{CONSIDERAÇÕES FINAIS}

Conforme assinalado no início deste trabalho, a preocupação a priori foi analisar e entender a problemática que intitulamos Juventude negra, drogas e racismo: redução de danos e combate ao genocídio da juventude negra. Ao longo da trajetória, surgiram diferentes ideias, pensamentos e reflexões que paulatinamente tomaram dimensão no corpo do trabalho, elencadas a seguir.

As energias despendidas no esforço de compreensão do processo de exclusão/inclusão nas cidades do Rio de Janeiro e São Paulo, e a configuração do atual desenho do perfil dos jovens negros, fluíram, à medida que se tomou contato direto com a literatura que discute a questão. Inicialmente, interessava entender o problema da violência entre representações e 
realidade, uma vez que esse tema é recorrente na vida cotidiana das pessoas, especialmente da juventude negra.

Nesse sentido, entender as políticas públicas de geração de redução de danos nesse contexto foi o viés que se delineou no sentido de contribuir para o debate desta problemática, assim como para pensar alternativas possíveis para o enfrentamento da violência e da discriminação racial, face às ocorrências que se fazem presentes no cotidiano das pessoas.

Quando se examina os conceitos, as teorias sobre a temática posta para discussão, e as pesquisas realizadas, observa-se que em São Paulo e no Rio de Janeiro existe uma singularidade no processo de exclusão social, visto que, de um modo geral, a reprodução do capital se dá em bases desiguais, gerando uma periferia muito pobre nas grandes cidades. Periferia que nem sempre usufrui dos bens e serviços produzidos pela sua própria força de trabalho. Todavia, essa periferia que se forma, contribui para a formação das áreas metropolitanas, assim como à medida que as camadas pobres e médias se afastam do centro, liberam a reorganização do espaço com a criação de novos bens e serviços que vão surgindo no cotidiano das cidades.

Uma vez colocadas inúmeras questões suscitadas pelas políticas públicas em vigor no Brasil a partir de 1980 e especialmente na década de 1990, tomando como referencial as Regiões Metropolitanas do Rio de Janeiro e de São Paulo, algumas questões são consideradas importantes e merecem destaque: os resultados do estudo não pretendem ser taxativos, assumindo o risco de "não estar tudo o que é ou, ainda, de não ser tudo o que está"; e as reflexões acerca do conhecimento do espaço estudado, por ter uma finalidade social, apenas intencionam que futuros pesquisadores possam avaliá-las, acrescentá-las, aprofundá-las ou refutá-las, de acordo com a flexibilidade, a provisoriedade e a relatividade do próprio conhecimento.

Após as reflexões e a materialização da atividade proposta, ficou evidente que a questão racial não é encarada naturalmente pelos estudantes. A sociedade brasileira ainda continua com certa nebulosidade em relação à percepção do racismo. Esta é uma questão velada por grande parte da população, visto que muitas pessoas têm preconceito, mas não assumem.

A maior parte dos jovens entende que a diversidade racial é normal e que a cada dia que passa a sociedade avança, porém em passos lentos. Percebem que a desigualdade existe, mas não admitem que seja somente por ser negro. Segundo suas concepções, a desigualdade é aparente em todas as etnias.

No tocante à questão da democracia racial, foi tratada com muita cautela no debate, pois ficou evidente que os discentes a aceitam quando é com os outros, é como se eles olhassem por 
uma ótica, de longe, mas quando se aproxima da situação, argumentam: "Peraí, agora é diferente".

Acreditam que no cotidiano existe o preconceito, mas dão uma contrapartida argumentando que o negro também tem preconceito contra brancos, querem todos os direitos, se reservam em grupos segregados e quando estão no poder agem de maneira discriminatória contra os brancos, como se fosse uma revanche. A branquitude se coloca como superiora de maneira camuflada, não admitida.

Durante o Júri, os alunos agiram muito bem, foi uma atividade em perfeita interação, até por ser uma turma do curso de Direito, eles já têm essa prática de Júri Simulado. No caso do debate, a turma reagiu dentro dos padrões de normalidade, sem piada nem risadas desagradáveis.

Cabe ressaltar que o Estado insiste na tese do país paraíso das raças, porem não é o que apontam as pesquisas. Em resposta a uma consulta feita pelo Comitê para a eliminação da Discriminação Racial - CEDR, os dados oficiais apresentam a imagem do descaso com os jovens negros no Brasil, quando o Estado assim se manifesta:

Tenho a honra de informar-lhe que, uma vez que a discriminação racial não existe no Brasil o Governo brasileiro não vê necessidade de adotar medidas esporádicas de natureza legislativa, judicial e administrativa a fim de assegurar a igualdade das raças (SILVA, 2008, p.94).

Em contraponto a essa resposta, o Brasil é apresentado nas estatísticas como um dos países com maior quantidade de casos de homicídios no mundo. Os registros apontam que "56 mil pessoas foram mortas em 2012". Nesse sentido, no que se refere aos dados reais, há verdadeiros estereótipos negativos associados à juventude, notadamente aos jovens negros que vivem em comunidades alijadas do processo de inclusão, especialmente nos Estados do Rio de Janeiro e de São Paulo, contribuindo para a banalização e a naturalização da violência.

Na perspectiva de destacar esses fatos, é possível afirmar que:

Em 2012, mais de 50\% de todas as vítimas de homicídios tinham entre 15 e 29 anos e, destes, 77\% eram negros. [...] Em um período de dez anos (20052014), foram registrados 8.466 casos de homicídio decorrente de intervenção policial no estado do Rio de Janeiro; 5.132 casos apenas na capital. Apesar da tendência de queda observada a partir de 2011, um aumento de quase 39,4\% foi verificado entre 2013 e 2014. O número de pessoas mortas pela Polícia representa parcela significativa do total de homicídios. Em 2014, por exemplo, os homicídios praticados por policiais em serviço corresponderam a $15,6 \%$ do número total de homicídios na cidade do Rio de Janeiro. (ANISTIA INTERNACIONAL, 2015). 
Se compararmos os dados do Rio de Janeiro com São Paulo em relação às taxas de homicídios, levando em conta um total de 100 mil habitantes, há de se considerar que a diferença é pouco significativa, pois de acordo com dados do SIM/SVS/MS, em 1998 o Estado do Rio de Janeiro era responsável por 55,3, ocupando o $3^{\circ}$ lugar no ordenamento nacional e em 2012 28,3, ocupando o $18^{\circ}$ lugar, enquanto São Paulo foi responsável por 39,7 e o $5^{\circ}$ na classificação e 15,1 e $26^{\circ}$ respectivamente no período observado.

Finalizando as ideias expostas em função dessa análise, incorpora-se o pensamento de Santos (2003):

\footnotetext{
A velocidade e o tempo real não podem ser distribuídos e usados igualmente por todos. A promessa de que as técnicas contemporâneas pudessem melhorar a existência de todos cai por terra. Observa-se a expansão da escassez, atingindo as classes médias e criando mais pobres (SANTOS, 2003, p.86).
}

Assim, há de se considerar que a questão da exclusão deverá ser discutida no âmbito das políticas públicas, especialmente da educação, pois os saberes escolares e seu relacionamento com outros saberes socialmente produzidos podem contribuir para a inserção do sujeito no mercado de trabalho e, consequentemente, para o exercício da cidadania.

Acredita-se que a globalização viabilizou uma enorme difusão de informações. O grande resultado é a comunicação que realmente está sem limites físicos de manipulação. Nesse sentido, a escola se tornou anacrônica à medida que não conseguiu acompanhar a concorrência dos meios de comunicação, principalmente as Tecnologias da Informação e da Comunicação no processo ensino e aprendizagem.

Talvez seja um sonho, uma utopia, mas é preciso acreditar e impulsionar essa humanidade para a felicidade individual e coletiva em um contexto social justo, na luta pela equidade social desejada. Por fim, fica a seguinte reflexão: será que a pós-modernidade vai resolver o problema da educação, da discriminação, do racismo e da violência contra a juventude negra?

\section{REFERÊNCIAS}

ABRAMOVAY, Miriam; CASTRO, Mary. Drogas nas escolas. Brasília: UNESCO; Rede Pitágoras, 2002.

ANISTIA INTERNACIONAL. Você matou meu filho: homicídios cometidos pela polícia militar na cidade do Rio de Janeiro. Rio de Janeiro: Anistia Internacional, 2015. Disponível em: 
https://anistia.org.br/wp-content/uploads/2015/07/Voce-matou-meu-filho_AnistiaInternacional-2015.pdf. Acesso em: 29 de janeiro de 2020.

ASSOCIAÇÃO BRASILEIRA DE NORMAS TÉCNICAS. NBR - 6023.Informação e documentação: elaboração: referências. Rio de Janeiro, 2002.

BRASIL. Diretrizes para projetos de redução de danos. Brasília: Ministério da Saúde; Secretaria de Projetos Especiais de Saúde; Coordenação Nacional de Doenças Sexualmente Transmissíveis.

FREIRE, Paulo. Pedagogia do Oprimido. 7. ed. Rio de Janeiro: Paz e Terra,1987, p. 39.

GUIMARÃES, Antonio Sérgio Alfredo. Racismo e antiracismo no Brasil. São Paulo: Editora 34, 2005.

MAZZOTTI, Alda Judith Alves ; GEWANDSZNAJDER, Fernando. O Método nas Ciências Naturais e Sociais: Pesquisa Quantitativa e Qualitativa. São Paulo: Pioneira, 1988.

ODÁliA, N. O Que é Violência. Coleção Primeiros Passos. São Paulo: Brasiliense, 1993.

RIBEIRO, Darcy. O Povo brasileiro: a formação e o sentido do Brasil. São Paulo: Companhia das Letras, 1995.

RIBEIRO, Janaína de Oliveira Nunes. Uso Pedagógico das Ferramentas de Interatividade. Juiz de Fora: Universidade Federal de Juiz de Fora, 2015.

RODRIGUES, Nelson. Abdias: o negro autêntico. In: Nascimento, Abdias. Última Hora. Rio de Janeiro: [S.1.: s.n.], 1957. p. 157- 158.

SANTOS, Milton. Por uma outra globalização: do pensamento único à consciência universal. 10. ed. Rio de Janeiro: Record, 2003.

SILVA, Silvio José Albuquerque E. Combate ao racismo. Brasília: Fundação Alexandre de Gusmão, 2008. 

COMO ALTERNATIVA NO ENSINO DE QUíMICA PARA ALUNOS COM DEFICIÊNCIA VISUAL

\author{
Leonardo Rafael Medeiros ${ }^{1}$
}

\begin{abstract}
RESUMO
As escolas enfrentam grandes desafios para promover a inclusão de estudantes com deficiência visual. Esses alunos precisam transpor, diariamente, diversas barreiras de ordem arquitetônica, comunicacional, atitudinal e pedagógica para obterem acesso, permanência e êxito nas escolas. No ensino de química, as dificuldades se intensificam, uma vez que assuntos abstratos provocam professores a utilizarem metodologias mais atraentes e adaptadas para poder ensinar alunos com deficiência visual. Dessa maneira, é importante que os professores em formação conheçam alternativas para ensinar tais conteúdos. Nessa perspectiva, este relato de experiência teve por objetivo proporcionar reflexões acerca da importância de se promover a inclusão de alunos com deficiência visual a partir da construção de modelos táteis sustentáveis como alternativa para o ensino de química com estudantes de licenciatura. Os alunos vivenciaram, a partir de uma experiência sensorial, o cotidiano de pessoas que apresentam cegueira e construíram tecnologias assistivas de baixo custo, utilizando recursos reutilizados e/ou recicláveis. O presente estudo evidenciou que a sensibilização dos futuros professores foi possível e que esses profissionais em formação perceberam que é factível a construção de materiais didáticos adaptados e eficientes para ensinar assuntos abstratos de química, sem a necessidade de grandes recursos financeiros. Essa sensibilização é um importante passo para que a construção de uma escola mais inclusiva e transformadora.
\end{abstract}

Palavras-chave: Inclusão. Tecnologias assistivas. Recursos grafo-táteis. Sustentabilidade.

\title{
INTRODUÇÃO
}

O paradigma da inclusão surgiu em meados da década de 1990 após um histórico extenso de preconceitos, práticas excludentes e atitudes segregadoras em relação às pessoas com deficiência. Esse histórico, porém, é também marcado por superações de desafios e avanços. Discussões a respeito da inclusão se intensificaram nas últimas décadas, em resposta às conquistas das pessoas com deficiência na sociedade como um todo, em especial no âmbito escolar.

Atualmente, difunde-se a ideia de promover que todas as pessoas sejam tratadas com igualdade, respeitando suas diferenças e assegurando-lhes seus direitos. Isso acontece porque compreende-se que a beleza e a riqueza de uma sociedade são pautadas na sua complexidade, que pode ser alcançada com uma maior heterogeneidade entre as pessoas (MANTOAN, 2003). Lutar pelos direitos de pessoas com deficiência é também lutar pelo direito de todos, o que

\footnotetext{
1 Mestre em Ecologia pela Universidade Federal do Rio Grande do Norte (UFRN). E-mail: leonardo.rafael@ifrn.edu.br
} 
contribui para a construção do caráter abrangente da inclusão, tendo em vista que ela não é focada apenas nas pessoas com deficiência, mas em todos os indivíduos na sociedade (MATOS, 2003).

Um dos grandes desafios enfrentados pelos professores é saber lidar com a grande heterogeneidade em uma sala de aula. Isso acontece porque cada indivíduo apresenta suas peculiaridades, maneiras diferentes de aprender e preferências metodológicas. Na práxis cotidiana, conseguir desenvolver metodologias que sejam eficientes para alunos tão diversificados é intrigante e ao mesmo tempo instigador (SAGRILO; PAIM, 2009). Quando o assunto é inclusão, professores muitas vezes precisam se utilizar da criatividade para poder desenvolver instrumentos pedagógicos e estratégias em sala de aula que visem contribuir para um melhor processo de ensino-aprendizagem, bem como a quebra de barreiras atitudinais.

Utilizar metodologias diferenciadas e inclusivas são ainda mais necessárias em disciplinas que requerem um nível maior de abstracionismo. A química, por exemplo, é uma ciência que estuda a matéria e suas transformações a nível molecular e, como consequência, muitos alunos apresentam dificuldades em entender os conceitos da matéria, suas propriedades, estrutura e reações (ROCHA; VASCONCELOS, 2016). Como consequência, é de fundamental importância que estratégias didáticas que abordem assuntos abstratos de forma mais concreta sejam utilizadas para melhorar sua compreensão e permitir uma aprendizagem mais significativa (MARQUES, 2018). Essas estratégias beneficiam não somente os alunos com deficiência, mas todos em sala de aula.

Para alunos com deficiência visual, uma alternativa para trazer para o concreto assuntos mais abstratos é a utilização de materiais grafo-táteis, uma vez que esses alunos podem utilizar o tato para facilitar a aprendizagem de conteúdos que são corriqueiramente ensinados com estímulos visuais.

\footnotetext{
A aprendizagem do aluno deficiente visual é mediada, essencialmente, pelo tato, juntamente com os demais sentidos remanescentes (audição, paladar e olfato). Essa característica de aprendizagem faz com que o aluno utilize esses sentidos na transformação do abstrato em conceito concreto, que deverá ser incorporado no seu desenvolvimento cognitivo. (CERQUEIRA; FERREIRA, 1996).
}

Verifica-se, portanto, que é importante sensibilizar os professores desde a sua formação para a necessidade de se trabalhar com recursos didáticos táteis em sala de aula, com o intuito de promover a acessibilidade pedagógica de deficientes visuais. Nesse sentido, é fundamental que as instituições de ensino superior sejam estruturadas na tentativa de se incentivar o desenvolvimento de práticas pedagógicas inovadoras e acessíveis. Além disso, é imprescindível 
que essas instituições apresentem um corpo docente consciente e mais preparado para receber alunos com deficiência e utilizar materiais didáticos acessíveis (CASTRO; ALMEIDA, 2014).

Diante da importância de se possibilitar uma formação de professores mais conscientes e sensíveis para atuar com deficientes visuais em sala de aula, o presente trabalho apresenta um relato de experiência com alunos do Curso Superior de Licenciatura em Química do Instituto Federal de Educação, Ciência e Tecnologia do Rio Grande do Norte - IFRN, campus Ipanguaçu. O objetivo desta pesquisa foi proporcionar reflexões acerca da importância de se promover a inclusão de alunos com deficiência visual a partir da construção de modelos táteis sustentáveis como alternativa para o ensino de química.

\section{ACESSIBILIDADE E ESTRATÉGIAS PEDAGÓGICAS}

Durante várias décadas, os alunos com necessidades educacionais especiais apresentaram grandes dificuldades de acompanhar os demais alunos e o professor em sala de aula, reforçando, assim, a prática da exclusão. Para mudar essa realidade, a inclusão escolar trouxe à tona discussões acerca da importância e necessidade de se proporcionar, aos alunos com limitações, maneiras de se adaptarem à escola comum. Para isso, é fundamental que haja meios de se implementar a acessibilidade no âmbito escolar (SASSAKI, 1997).

Segundo a Lei 13.146/2015, conhecida como o Estatuto da Pessoa com Deficiência, acessibilidade é entendida como a "possibilidade e condição de alcance para utilização, com segurança e autonomia, de espaços, mobiliários, equipamentos urbanos, edificações, transportes, informação e comunicação, inclusive seus sistemas e tecnologias" (BRASIL, 2015). Portanto, a acessibilidade e a implementação da inclusão na prática somente são possíveis se uma série de barreiras forem eliminadas, a fim de garantir o livre acesso, permanência e êxito de pessoas com deficiência na escola.

$\mathrm{Na}$ perspectiva da integração, bastante difundida na segunda metade do século XX e que antecedeu o paradigma da inclusão, os entraves existentes no ambiente escolar precisavam ser superados pelos próprios alunos. Porém, muitos deles apresentavam limitações que não lhes permitiam transpor esses obstáculos e, portanto, não conseguiam usufruir dos seus direitos e ter uma educação de qualidade. Portanto, é imprescindível que as mais diversas barreiras sejam eliminadas pela instituição escolar, garantindo, assim, igualdade de oportunidades aos alunos (SASSAKI, 1997).

A acessibilidade escolar trabalha na perspectiva de extinguir as barreiras existentes nas mais diversas ordens, sejam elas arquitetônicas, comunicacionais, atitudinais, pedagógicas, 
entre outras (SASSAKI, 2002). As barreiras arquitetônicas são aquelas de ordem física, que, muitas vezes, impedem o ir e vir de alunos no ambiente escolar. Como os deficientes visuais se utilizam dos outros sentidos para poderem se deslocar, então pisos táteis, rampas de acesso, corrimões e elevadores são elementos da infraestrutura que possibilitam maior autonomia desses alunos ao circularem nos espaços comuns da escola.

Barreiras comunicacionais para deficientes visuais envolvem, sobretudo, a comunicação escrita, pois a utilização do Braille ainda não é bastante difundida entre as instituições de ensino. As barreiras atitudinais, por outro lado, são muitas vezes difíceis de serem eliminadas, pois não são facilmente identificadas e envolvem mudanças de postura e comportamento de todos os indivíduos que frequentam o âmbito escolar. Atitudes discriminatórias e bullying ainda estão presentes no dia-a-dia de alunos com deficiência, uma vez que muitos jovens têm dificuldades em conviver com as diferenças, por puro desconhecimento ou falta de sensibilidade para compreender o outro (PONTE; SILVA, 2015).

Além de todos esses entraves, as barreiras no aspecto pedagógico são uma das que mais dificultam a compreensão dos conteúdos pelos alunos com necessidades educacionais especiais em sala. No tocante aos alunos com deficiência visual, os materiais táteis podem ser utilizados como estratégia pedagógica inclusiva, favorecendo o aprendizado de diversos conteúdos (SÁ et al., 2007). Apesar de simples, esses recursos podem ser bastante inovadores por conferirem mais dinamismo e motivação ao processo de ensino-aprendizagem, tornando-o mais significativo (AUSUBEL, 1982).

\section{TECNOLOGIAS ASSISTIVAS E SUSTENTABILIDADE}

No século XXI, a tecnologia trouxe avanços cada vez mais expressivos para área educacional, sempre na tentativa de ampliar a qualidade de práticas de ensino e proporcionar experiências mais inclusivas para os discentes (HONORA, 2017). No tocante à inclusão escolar, a tecnologia assistiva é definida pelo Comitê de Ajudas Técnicas do Brasil como:

(...) uma área do conhecimento, de característica interdisciplinar, que engloba produtos, recursos, metodologias, estratégias, práticas e serviços que objetivam promover a funcionalidade, relacionada à atividade e participação de pessoas com deficiência, incapacidades ou mobilidade reduzida, visando sua autonomia, independência, qualidade de vida e inclusão social. (BRASIL Comitê de Ajudas Técnicas - ATA VII, 2007).

Compreende-se, portanto, que quaisquer instrumentos ou práticas que têm como objetivo proporcionar a inclusão de pessoas com necessidades especiais são consideradas 
tecnologias assistivas. De uma maneira geral, esses recursos contribuem para ampliar habilidades funcionais dos alunos com deficiência e são importantes para a promoção da sua independência e inclusão (BERSCH, 2017).

Muito embora a compreensão de tecnologias assistivas possa trazer concepções equivocadas, uma vez que muitos podem entender que os materiais assistivos envolvem apenas equipamentos eletrônicos e de alta tecnologia, percebe-se que o conceito engloba desde a utilização de uma prancha de comunicação alternativa a um computador com leitor de tela. No caso dos materiais táteis, eles são incluídos dentro da categoria das tecnologias assistivas que envolvem auxílios para qualificação da habilidade visual e recursos que ampliam a informação às pessoas com deficiência visual (BERSCH, 2017).

Apesar de existir um grande despreparo dos professores para saber ensinar a alunos com deficiência visual e muitos alegarem que não existe incentivo ou recursos para a compra de materiais inclusivos, o conceito abrangente de tecnologias assistivas evidencia uma ideia interessante. Percebe-se que existem alternativas de baixo custo e até mesmo sustentáveis que podem ser utilizadas em sala e que apresentam bastante eficácia.

Como os deficientes visuais constroem seu conhecimento e adquirem sua subjetividade através dos sentidos remanescentes, a citar o tato, usar materiais reutilizados ou recicláveis de diferentes texturas para confeccionar recursos grafo-táteis são uma excelente maneira de proporcionar que alunos cegos visualizem com maior facilidade os assuntos vistos em sala de aula (SÁ et al., 2007). Essa opção é interessante por diversos motivos, seja do ponto de vista da economia - pelo seu baixo custo -, da criatividade - por proporcionar enriquecimento profissional - e da sustentabilidade - por promover a reutilização de resíduos sólidos.

Neste exato momento, o meio ambiente está sofrendo com a problemática do descarte incorreto de bilhões de toneladas de lixo, provenientes do consumo de diversos produtos, resultado das atividades humanas (POLLI; SOUZA, 2013). Entretanto, frequentemente a palavra lixo é utilizada como sinônimo de resíduo. Lixo pode ser entendido como todo material descartado pelo homem, porém, ao realizarmos a separação desse lixo, os materiais que podem ser reutilizados como matéria-prima para confecção de outros produtos são chamados de resíduos sólidos (CINQUETTI, 2004).

Observa-se, portanto, que o lixo pode ser fonte de matéria-prima para confecção de diversos produtos, diminuindo os impactos que ele poderia causar no ambiente, caso seu descarte fosse feito de maneira inadequada. A prática de reutilização de resíduos sólidos, destinando parte do lixo para construção de algo com grande valor utilitário, e nesse caso pedagógico, possibilita ressignificar o lixo (ASSAD, 2016). Além disso, esse processo de 
ressignificação propicia, inclusive, uma reflexão individual sobre as atitudes humanas perante o planeta.

Desenvolver tecnologias assistivas de baixo custo a partir de resíduos sólidos também se configura como uma possibilidade de enriquecimento profissional. Atitudes como essa oportunizam que professores se desafiem cotidianamente, aperfeiçoando sua práxis e utilizando da criatividade e inovação. Grandes ideias surgem no momento em que o professor se reinventa e se permite pensar de forma diferente, na tentativa de contribuir para vencer as barreiras impostas pelas limitações dos alunos com deficiência, sendo compensador e positivo para os alunos e docentes (SAGRILO; PAIM, 2009).

A reinvenção da práxis docente é, inclusive, um dos grandes benefícios que a inclusão traz para os profissionais de educação, uma vez que a busca por essa reinvenção é possibilitada pelo contato com alunos com deficiência e se caracteriza como um grande crescimento profissional. Os desafios trazidos pela implementação da inclusão mobilizam os docentes a reavaliar e consequentemente recriar suas próprias práticas educativas, trazendo novas possibilidades e perspectivas metodológicas. Essas transformações na escola comum trazem dinamismo e benefícios não somente para os alunos com deficiência, mas para todos (MANTOAN, 2011).

\section{METODOLOGIA}

O presente estudo se caracteriza como uma pesquisa de cunho qualitativo, desenvolvida ao longo do ano de 2019 em duas turmas da disciplina de Educação Inclusiva do Curso Superior de Licenciatura em Química do Instituto Federal de Educação, Ciência e Tecnologia do Rio Grande do Norte - IFRN, campus Ipanguaçu. Ao longo da disciplina, diversas características da inclusão foram discutidas, desde o histórico da educação inclusiva, legislação, seus benefícios e dificuldades de implementação, além de estratégias pedagógicas a serem utilizadas em sala de aula com alunos com necessidades educacionais especiais.

As atividades propostas envolvendo a deficiência visual, foco desta pesquisa, foram divididas nas seguintes etapas metodológicas:

i) Experiência sensorial: A primeira etapa tinha o objetivo de proporcionar aos alunos uma vivência sobre o dia-a-dia de um aluno cego no ambiente escolar. Para tanto, todos os alunos foram vendados e cada um recebeu uma missão (por exemplo, ir até a cantina e comprar um salgado, ir à coordenação do curso e pedir uma caneta ou ir à biblioteca 
e pegar um livro emprestado). Em seguida, foi feita uma roda de conversa em que os alunos socializaram suas emoções sobre a experiência.

ii) Discussão das estratégias pedagógicas: Na segunda etapa, foi feita uma discussão geral sobre os aspectos da deficiência visual, enfatizando as diversas adequações metodológicas e de material didático a serem utilizadas em sala de aula. Nesse momento, foi discutida a importância da confecção de materiais grafo-táteis.

iii) Elaboração da tecnologia assistiva: Os alunos confeccionaram um material didático assistivo tátil, que possibilitasse a ampliação das habilidades funcionais de alunos cegos. Os recursos desenvolvidos deveriam obrigatoriamente servir de auxílio para qualquer disciplina do Curso Superior de Licenciatura em Química. Os alunos foram instigados a identificar os assuntos que os professores do curso teriam mais dificuldade em lecionar a um aluno cego. Os materiais grafo-táteis foram confeccionados com a utilização de materiais reutilizados e/ou recicláveis de diferentes texturas e formas, em alto relevo ou tridimensionais e de fácil manuseio.

iv) Apresentação dos materiais produzidos: Cada grupo realizou uma exposição dos recursos táteis, bem como fizeram uma breve explanação e demonstração sobre como eles seriam utilizados em sala de aula. Para isso, três alunos foram vendados e o material tátil foi testado. Ao final, foram realizadas discussões acerca da experiência, em que foram relatadas as dificuldades e os esforços que cada grupo apresentou para elaboração do produto tátil, além de como a vivência contribuiu para a sua formação como futuros professores de química.

\section{RESULTADOS E DISCUSSÃO}

Ao longo do desenvolvimento desta pesquisa, constatou-se que essa vivência foi bastante transformadora e contribuiu positivamente para a formação dos futuros profissionais na área da educação. Verificou-se que os alunos foram sensibilizados como resultado do contato que eles tiveram com as limitações e barreiras que os deficientes visuais precisam transpor no dia-a-dia. Esse conhecimento permitiu uma reflexão sobre os desafios que esses alunos apresentam diariamente, possibilitando, assim, uma maior empatia.

Os relatos socializados após a vivência sensorial incluíram sensações de medo, angústia, agonia e tristeza. Indagados sobre os motivos que os levaram e terem esses sentimentos, os alunos discutiram que, como o ser humano é muito dependente da visão para se deslocar, eles se sentiam incapazes de realizar as ações de forma autônoma. Muitos relataram receio de 
tropeçar, cair ou se machucar com algum obstáculo, bem como a dificuldade em se obter uma percepção espacial do ambiente. Esses sentimentos são comuns em cegos, sobretudo aqueles com perda visual adquirida, cuja condição do não ver tem implicações na saúde mental dessas pessoas, principalmente durante a vivência das fases iniciais do processo de luto, em decorrência da perda sensorial (AMORIM, 2016).

Essa experiência foi interessante, pois os alunos público-alvo desse estudo vivenciaram os desafios enfrentados pelos deficientes visuais cotidianamente. Além disso, eles puderam identificar algumas estratégias utilizadas para possibilitar sua locomoção, bem como os recursos da infraestrutura que promovem a acessibilidade arquitetônica e comunicacional do campus. Dentre eles, os alunos citaram a importância do piso-tátil, da identificação das salas em Braille e de corrimão, uma vez que esses recursos estavam ausentes na instituição ou estavam instalados de forma inadequada. Dessa forma, a principal maneira que eles encontraram para se locomover foi com o auxílio dos estudantes que não estavam vendados.

No segundo momento, durante as discussões acerca das estratégias pedagógicas a serem utilizadas para ensinar alunos com baixa visão e cegueira, diversas metodologias adaptadas, assim como mudanças de comportamento e de postura do professor em sala de aula, foram amplamente discutidas. As tecnologias assistivas que foram apresentadas compreenderam os recursos ópticos (e.g., lupa, telelupa monocular), recursos didáticos ampliados, o sistema Braille, além de exemplos variados de materiais táteis.

Após terem conhecimento sobre como é o cotidiano de uma pessoa com deficiência visual e as diversas alternativas para se promover sua inclusão no ambiente escolar, os alunos conseguiram confeccionar materiais táteis envolvendo os assuntos de química orgânica (Figura 1), soluções e misturas, distribuição eletrônica, níveis de energia e lógica computacional (Figura 2). 
Figura 1. Material tátil de química orgânica, com a representação espacial das ligações químicas entre os átomos de hidrocarbonetos e legenda em Braille.

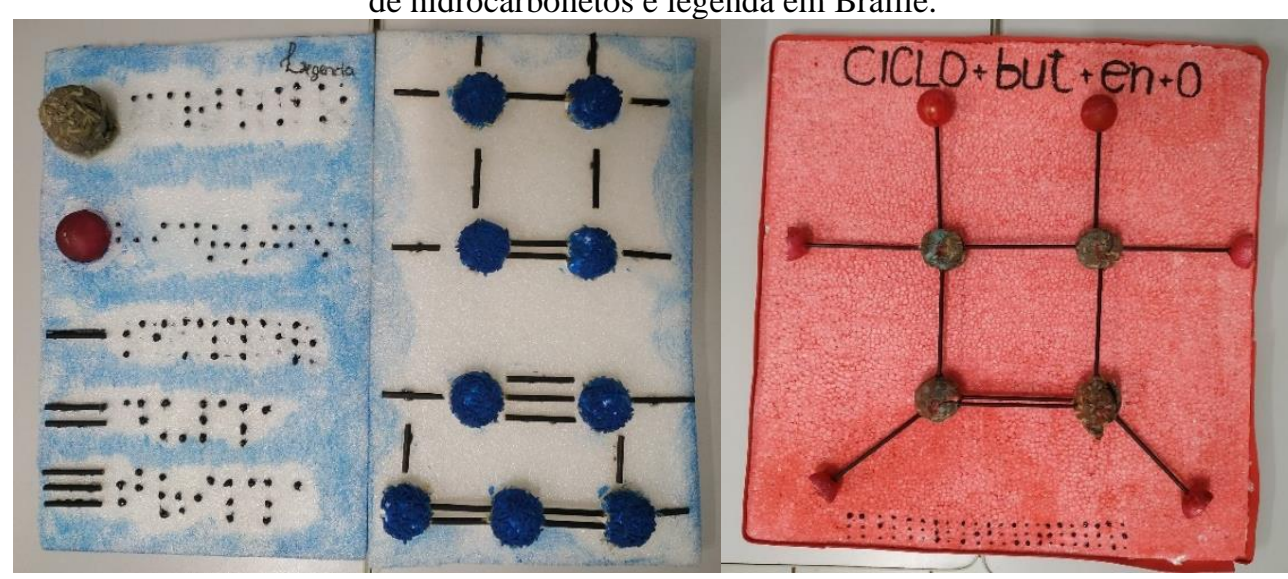

Fonte: Elaborado pelo pesquisador.

A maioria dos materiais utilizados foram aproveitados de outros trabalhos acadêmicos e eram recicláveis ou de baixo custo. No momento das apresentações das tecnologias assistivas produzidas, os alunos propuseram a utilização de tais recursos durante a explicação dos conteúdos, para facilitar a resolução de atividades ou até mesmo como instrumentos avaliativos. Essa ideia está de acordo com o proposto por Sá e colaboradores (2007), os quais expõem a importância da utilização do bom senso e criatividade para selecionar, confeccionar ou adaptar recursos utilizando material de baixo custo e sucata, inclusive para a avaliação.

Figura 2. Jogo de tabuleiro tátil para o ensino de lógica computacional. Estão representadas as funções de

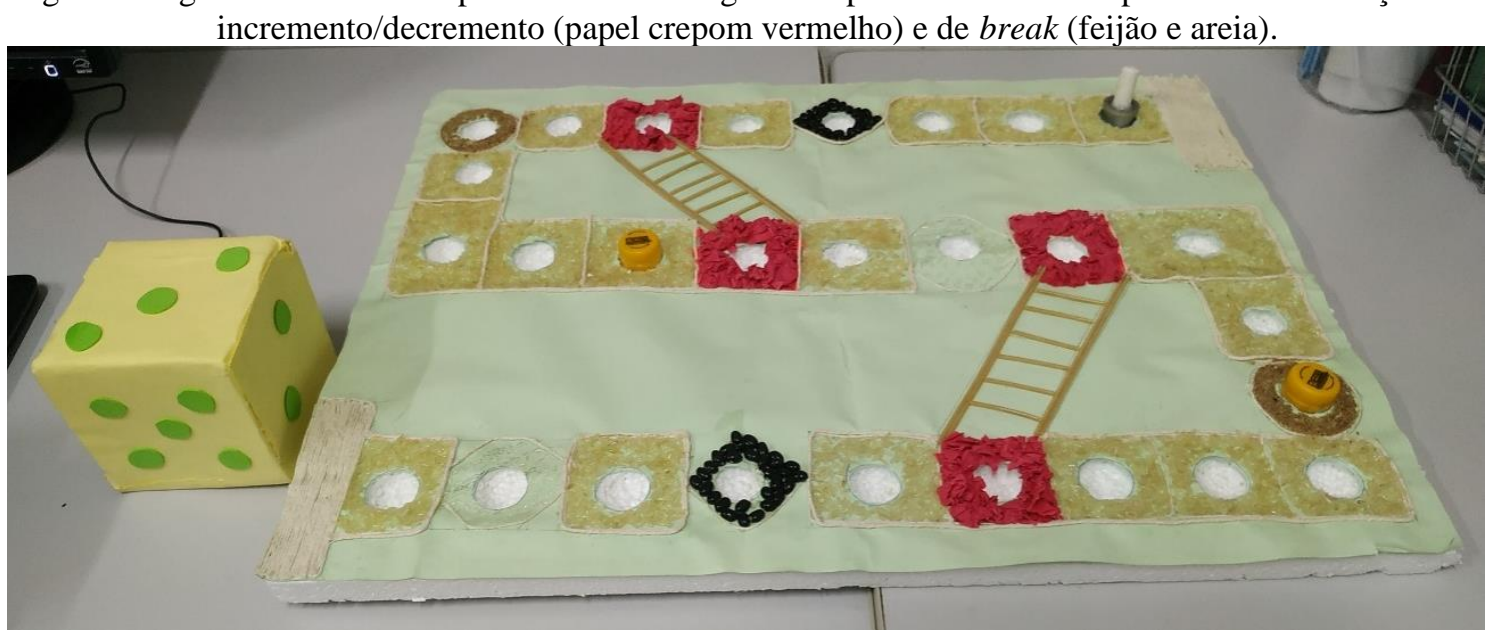

Fonte: Elaborado pelo pesquisador

Durante a apresentação do recurso tátil sobre soluções e misturas (Figura 3), os três alunos que foram vendados para testar o material conseguiram classificar satisfatoriamente se a mistura era homogênea ou heterogênea e, no caso da segunda, responderam corretamente a 
quantidade de fases. Nesse momento, os alunos verificaram a grande eficácia que esses instrumentos didáticos simples possuem, pois, segundo Sá e colaboradores (2007), estímulos táteis que apresentam clareza, qualidade e simplicidade ampliam a habilidade de compreender, interpretar e assimilar a informação na forma de imagens mentais por alunos sem referencial perceptivo visual.

Figura 3. Material tátil sobre soluções e misturas confeccionado a partir de materiais reutilizados. A: mistura homogênea; B: mistura heterogênea com duas fases; C: mistura heterogênea com três fases;

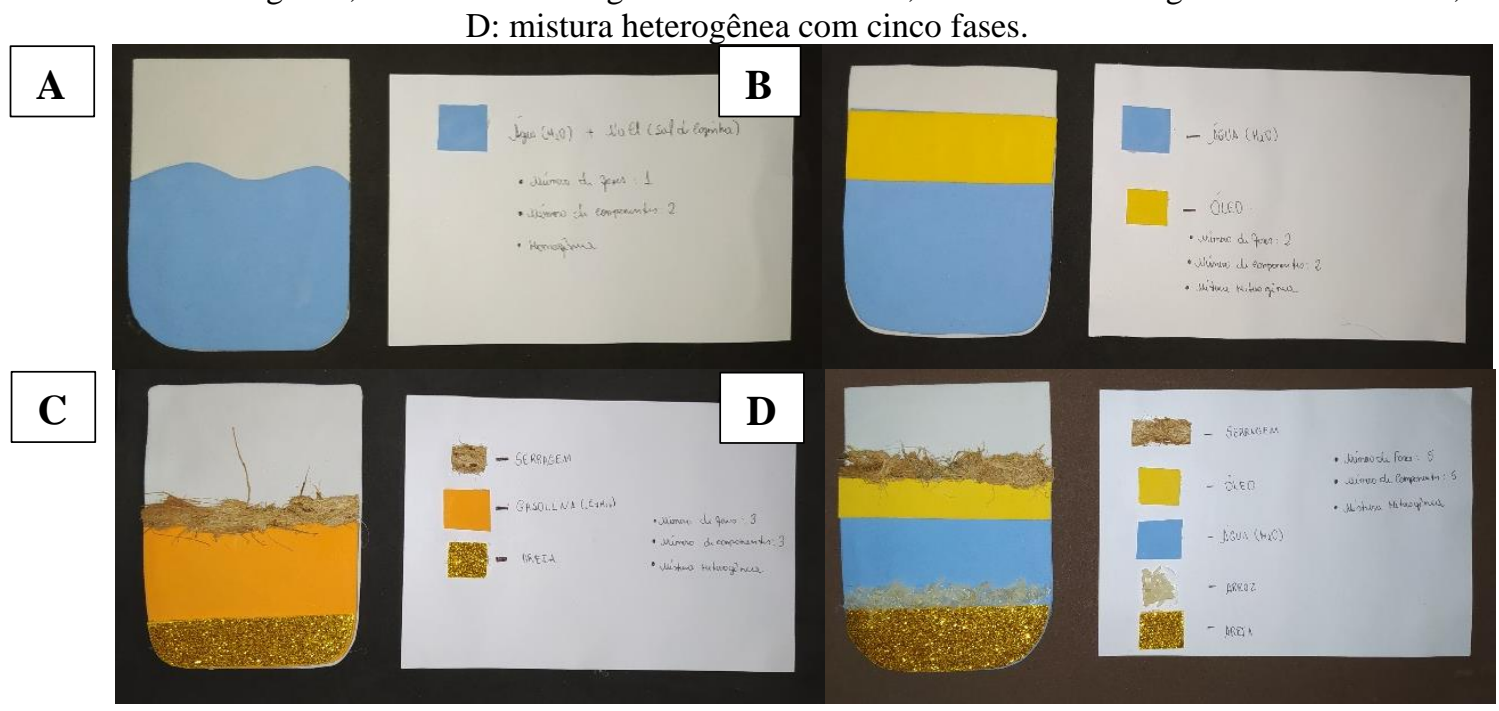

Fonte: Elaborado pelo pesquisador.

Os alunos pontuaram que a utilização de materiais reutilizados era uma excelente opção para as escolas em que a falta de recursos é uma realidade, aliado ao fato de ser uma alternativa sustentável. Além disso, foi discutido que a inclusão de alunos com deficiência visual é perfeitamente factível se existir, a priori, empatia por parte dos profissionais de educação, para, então, com comprometimento e proatividade, ser possível construir alternativas simples e eficientes, como os materiais táteis apresentados.

Em uma das falas, um aluno disse que essas experiências proporcionaram muitas reflexões e certamente "fizeram de mim uma pessoa melhor". Essa confissão certamente é uma forte evidência de que a ideia de ter contato com as diferenças e refletir sobre ações de ordem pessoal proporcionam transformações individuais profundas e enriquecimento profissional, sendo um importante passo para a sensibilização dos jovens futuros professores. Essa experiência está em consonância com os relatos de Stainback e Stainback (1999), que afirmam que a inclusão traz múltiplos benefícios, que envolvem desde os alunos com deficiência até os ditos "normais", como também os professores. 


\section{CONSIDERAÇÕES FINAIS}

O cenário atual das escolas brasileiras apresenta um grande paradoxo entre a relação inclusão e exclusão, tendo em vista que se difunde a ideia de se promover a inclusão de estudantes com necessidades educacionais especiais no âmbito escolar, porém não se oferece os subsídios necessários para que o processo de ensino-aprendizagem desses alunos seja efetivamente concretizado na prática. O presente estudo demonstrou que, apesar de muitos atribuírem a falta de recursos e incentivos como causa desse fracasso escolar, existem alternativas de baixo custo e sustentáveis para se promover a inclusão em sala de aula para estudantes com deficiência visual.

É notório que uma sensibilização é necessária durante o processo de formação de professores para que os futuros profissionais em educação sejam mais empáticos e abertos para a causa inclusiva. Ter conhecimento das diferenças e das limitações enfrentadas por alunos com deficiência é o primeiro passo para se promover reflexões que possam levar a grandes transformações de ordem interna por parte dos educadores. Essas mudanças são necessárias para que os futuros professores sejam mais sensíveis, proativos e propensos a reinventar constantemente sua prática docente, com o intuito de possibilitar a inclusão em sala de aula.

Este relato de experiência evidencia a grande importância de se desenvolver ações de conscientização com os profissionais de educação, a fim de que as diversas barreiras que cercam o cotidiano dos alunos com necessidades educacionais especiais sejam eliminadas. Uma escola mais aberta às diferenças é uma escola mais rica e transformadora, capaz de contribuir para uma educação mais cidadã e uma sociedade livre de preconceitos.

\section{REFERÊNCIAS}

AMORIM, É. G. Saúde mental de sujeitos com deficiência visual sob a ótica dos determinantes sociais de saúde. 2016. 110f. Dissertação (Mestrado) - Universidade Federal do Rio Grande do Norte, Natal, RN, 2016.

ASSAD, L. Lixo: uma ressignificação necessária. Ciência e Cultura, v. 68, n. 4, p. 22-24, 2016.

AUSUBEL, D. P. A. Aprendizagem significativa: a teoria de David Ausubel. São Paulo: Moraes, 1982.

BERSCH, R. Introdução à tecnologia assistiva. [S.1.: s.n.], 2017. Disponível em: http://www.assistiva.com.br/Introducao_Tecnologia_Assistiva.pdf. Acesso em: 12 mar. 2020. 
BRASIL. Lei Brasileira de Inclusão da Pessoa com Deficiência (Estatuto da Pessoa com Deficiência) - Lei 13.146.2015. Disponível em: https://goo.gl/YNFeXj. Acesso em:12 mar. 2020.

$2007 . \quad$ Disponível em:

Comitê de Ajudas Técnicas - ATA VII. Secretaria Especial dos Direitos Humanos. https://www.assistiva.com.br/Ata_VII_Reunião_do_Comite_de_Ajudas_Técnicas.pdf. Acesso em: 12 set. 2018.

CASTRO, S. F.; ALMEIDA, M. A. Ingresso e permanência de alunos com deficiência em universidades públicas brasileiras. Revista Brasileira de Educação Especial, v.20, n.2, p. 179194, 2014.

CERQUEIRA, J. B.; FERREIRA, M. A. Os recursos didáticos na educação especial. Rio de Janeiro: Revista Benjamin Constant, Rio de Janeiro, dez. 1996.

CINQUETTI, H. S. Lixo, resíduos sólidos e reciclagem: uma análise comparativa de recursos didáticos. Educar em Revista, n. 23, p. 307-333, 2004.

HONORA, M. Inclusão Educacional de Alunos com Surdez: concepção e alfabetização. São Paulo: Cortez, 2017. 200 p.

MANTOAN, M. T. Inclusão escolar: O que é? Por quê? Como se faz?. São Paulo: Ed. Moderna, 2003.

O desafio das diferenças nas escolas. Petrópolis: Vozes, 2011.

MARQUES, N. P. A deficiência visual e a aprendizagem da química: Reflexões durante o planejamento e a elaboração de materiais didáticos táteis. 2018. 120f. Dissertação (Mestrado Profissional) - Universidade Federal de Uberlândia, Uberlândia, MG, 2018.

MATOS, S. R. Educação, cidadania e exclusão à luz da Educação: retrato da teoria e da vivência. Revista Benjamin Constant, Rio de Janeiro, 2003.

POLLI, F. G.; SOUZA, A. A. Relação de consumo e meio ambiente: Proposta de responsabilização efetiva das fabricantes e comerciantes de bens e serviços pelo recolhimento dos resíduos sólidos dos produtos comercializados. In: CONGRESSO INTERNACIONAL DE DIREITO AMBIENTAL E ECOLOGIA POLÍTICA - UFSM, 1., Santa Maria, 2013. Anais [...] Santa Maria: [s.n.], 2013. v. 1 p 185-194.

PONTE, A. S.; SILVA, L. C. A acessibilidade atitudinal e a percepção das pessoas com e sem deficiência. Cadernos Brasileiros de Terapia Ocupacional, v. 23, n. 2, p. 261-271, 2015.

ROCHA, J. S.; VASCONCELOS, T. C. Dificuldades de aprendizagem no ensino de química: algumas reflexões. In: ENCONTRONACIONAL DE ENSINO DE QUÍMICA, 18. Florianópolis, 2016. Anais [...] Santa Catarina: [s.n.], 2003.

SÁ, E. D.; CAMPOS, I. M.; SILVA, M. B. C. Atendimento Educacional Especializado Deficiência Visual: Formação Continuada a Distância de Professores para o Atendimento 
Educacional Especializado. [S.1.: s. n.], 2007. Disponível em: http://portal.mec.gov.br/seesp/arquivos/pdf/aee_dv.pdf. Acesso em: 14 mar. 2020.

SAGRILO, L. C.; PAIM, M. C. C. Sentimentos que permeiam o processo de inclusão de alunos portadores de deficiência visual. Lecturas: Educación Física y Deportes - Revista Digital, v.14, n. 133, 2009.

SASSAKI, R. K. Inclusão: construindo uma sociedade para todos. Rio de Janeiro: WVA, 1997.

SASSAKI, R. K. Terminologia sobre deficiência na era da inclusão. Revista Nacional de Reabilitação, v. 5, n. 24, p.6-9, 2002.

STAINBACK, S.; STAINBACK, W. Inclusão: um guia para educadores. Porto Alegre: Artes Médicas, 1999. 456 p. 


\title{
O CANTO CORAL COMO CONTRIBUIÇÃO NA FORMAÇÃO HUMANA NO IFRN: UM RELATO DOS CAMPI IPANGUAÇU E NOVA CRUZ
}

\author{
Artur Fabiano Araujo de Albuquerque ${ }^{1}$ \\ Luciana Real Limeira ${ }^{2}$
}

\begin{abstract}
RESUMO
O presente capítulo discorre sobre práticas de Canto Coral enquanto instâncias educativas presentes em dois diferentes contextos, o qual contribui na formação humana dos seus participantes. É refletido a partir de arcabouço teórico que trata da Música dentro de sua perspectiva e prática social, na Musicalização, enquanto linguagem, e as formas e características dos coros nas suas formas de atuação. Apoiando-se principalmente como uma ação plenamente humana, o Canto Coral estabelece vínculos afetivos com a Música, formas de interação e aprendizado em grupo, bem como momentos de aprendizados musicais nos desdobramentos da Musicalização. Ao final, apontamos como a Educação Musical é um canal principal para o desenvolvimento das atividades descritas e como beneficia e colabora para o crescimento do conhecimento musical dos seus participantes, via atividade de grupo.
\end{abstract}

Palavras-chave: Canto Coral. Educação Musical. Musicalização. Prática Social. Formação Humana.

\section{INTRODUÇÃO}

Inicialmente, para a elaboração deste trabalho, focamos o olhar para as práticas de Canto Coral realizadas nos campi Ipanguaçu e Nova Cruz, ambos do Instituto Federal do Rio Grande do Norte - IFRN. Estas práticas estão inseridas nos Núcleos de Arte e Cultura dos referidos campi e trazem para o centro do debate, ações extensionistas, as quais são realizadas com alunos destes campi, servidores, terceirizados e pessoas das comunidades adjacentes a esses locais.

O estudo foi apoiado no referencial teórico que reflete sobre a prática coral dentro das perspectivas sociais (PEREIRA e VASCONCELOS, 2007; PENNA, 2010; QUEIROZ, 2005; SOUZA, 2007, 2014), a Música enquanto linguagem (PENNA, 2005, 2010), o canto coral enquanto forma de Musicalização (GAINZA, 1988; PENNA, 2005, 2010), formação e educação musical (MATHIAS, 1986); e os coros e seus gêneros formais de atuação (JUNKER, 1999).

A metodologia utilizada neste estudo contou com a revisão bibliográfica descrita acima, bem como os relatos dos regentes dos referidos Corais, discutindo os efeitos das

\footnotetext{
${ }^{1}$ Mestre em Educação Musical (UFPB). E-mail: artur.albuquerque@ifrn.edu.br

${ }^{2}$ Mestre em Educação Musical (UFPB). E-mail: luciana.real@ifrn.edu.br
} 
reflexões dos teóricos sobre as práticas de condução, de ensaio e os processos de musicalização e aprendizado da Música. Os sentidos, os vínculos estabelecidos com o fazer musical e os contextos serão apontados como instâncias plurais e efetivas para que o cantar em grupo seja um momento significativo para todos os envolvidos.

Nesse sentido, pensar uma prática coral que integre os participantes, fazendo com que os mesmos reconheçam o material sonoro como fator de musicalização, nos meandros socioculturais, multiculturais, percebendo também as características e atuação que cada tipo de coro pode e deve atuar, deve ser uma instância de reflexão para a Educação Musical na atualidade.

\section{CANTO CORAL, PRÁTICAS SOCIAIS E LINGUAGEM}

Notoriamente, diante dos vários estudos da Educação Musical, compreendemos a Música como linguagem, e esta, sendo socialmente construída diante dos contextos e realidades socioculturais e suas peculiaridades (PENNA, 2010; QUEIROZ, 2005). O Canto Coral encontra-se presente nesses contextos, permitindo com que seus participantes se tornem atores de um processo de aprendizagem no qual a interação, os processos de socialização e partilhas sejam elementos fundamentais (PEREIRA, VASCONCELOS, 2007; SOUZA, 2004). Sendo assim, é salutar a discussão, bem como as inquietações para nossa reflexão acerca da prática do Canto Coral e sua atuação no processo de socialização, partilhas e interação.

Todavia, devemos enfatizar o foco de verificação e compreensão da Música enquanto linguagem socialmente construída. Penna (2010) discorre que "A Arte de modo geral - e a Música aí compreendida - é uma atividade essencialmente humana, através do qual o homem constrói significações na sua relação com o mundo" (PENNA, 2010, p. 20), pressupondo assim a ação do Canto Coral como uma dessas atividades, que permite ao ser humano a construção de significações. Nesse sentido, a Música e sua rede de partilhas, enquanto linguagem e atividade humana, são construídas nessa rede de interação na qual a ação humana é primordial. Por isso, é construída socialmente, diante dessa necessidade de ter o homem como agente socializador que, uma vez, segundo a autora, é culturalmente construída, diferenciando-se de cultura para cultura.

As familiaridades das melodias presentes nos contextos, as formas como os jovens, crianças e adultos consomem estão situados numa rede de solidariedade em que a Música é o elemento que une, que por si só cria os laços de aprendizado e de interação. O Canto Coral, 
como prática que integraliza, permite que seus participantes sejam ativos numa rede de partilhas em que a Música seja socialmente compartilhada e construída por essas partilhas.

Portanto, neste ensejo em que a prática coral está configurada como uma ação humana, socialmente construída enquanto linguagem, bem como uma prática social na qual a interação e a rede de partilha são necessárias, compreendemos que esta prática se configura dentro da sociedade como instância importante para o aprendizado de seus participantes. Cabe aos regentes e educadores musicais debater possibilidades de incrementos e compreensão para que estes contextos tenham suas ações melhor direcionadas.

\section{CANTO CORAL E MUSICALIZAÇÃO}

Cantar é uma atividade feita exclusivamente pelo ser humano. O Canto Coral, como exposto acima, é uma prática social. Nesse sentido, enquanto prática social, esquemas de trocas são estabelecidas pelos participantes, o que faz com que estes aprendam Música, de forma peculiar, mesmo não sendo a forma tradicional ou formal.

Segundo Gainza (1988), a Música por si só faz o trabalho de musicalização, fazendo canais de comunicação e expressão. Nessa direção, a ação de cantar em conjunto, aliada às partilhas, realiza esses esquemas de construção de uma rede de comunicação. Um coralista é importante? Não, todos são! Um precisa do outro, um coral não é uma só pessoa, são todas! Dessa maneira, uma rede de comunicação e de trocas permite aos seus participantes se musicalizarem através do cantar em conjunto.

De acordo com Pereira e Vasconcelos (2007), no processo de socialização do Canto Coral, existe a necessidade de conscientização do EU (si mesmo) e depois do OUTRO (que não eu), mostrando que nessa ação ambos são necessários, pois, como haveria assim as partilhas, as formas de aprender com a pessoa próxima, incluindo-se o regente do coro? Salientamos que para que ocorra a musicalização dos participantes faz-se necessário que principalmente os regentes deem a devida atenção individual aos coralistas, para que o coletivo se fortaleça. Vínculos positivos com a própria Música são dispositivos necessários para que ocorra uma receptividade do material sonoro (GAINZA, 1988, p. 101). Assim, essa apropriação do material sonoro e o processo de socialização são elementos indispensáveis para que o processo de musicalização no canto coral ocorra de modo fluente e eficaz, pois ninguém aprende sem a provocação, sem dispositivos eloquentes de interação e sem elementos motivadores para a absorção da Música. 


\section{CANTAR PARA ENCANTAR}

A prática coral, por excelência, trata de atividade em conjunto, desenvolvida por pessoas de interesse em comum: cantar, principalmente. E por atividade em conjunto, não podemos negar que a união das pessoas envolvidas faz com que a natureza de qualquer conjunto, seja artístico, seja de estudos, por exemplo, obtenha sucesso a partir de dedicação e responsabilidade com a proposta de trabalho. Ainda de acordo com Junker (2010) quando nos referimos à Música, sabemos o quanto ela é primordial no processo de educação, seja formal ou não, pois a mesma contribui para o desenvolvimento do ser humano nos diversos meios de convivência. Para a realização deste trabalho temos como objetivo principal destacar as atividades de grupos corais distintos - Coral Vale Vocalis, Vozes do Agreste e Cantar't - observando a inclusão das práticas vocais e suas implicações nas comunidades acadêmicas e do entorno dos Institutos estudados. Tratamos aqui a Educação Musical como formação musical, contando com práticas musicais realizadas em diversos ambientes, formal ou não formal.

De acordo com Souza (2014, p. 92), “[...] ensinar e aprender música que são feitas no mundo cotidiano vivido". A partir dessa ideia, construímos as práticas musicais destes grupos corais, valorizando o conhecimento do aluno, trazendo para dentro da escola a experiência vivida fora dos muros escolares. Em contrapartida, as práticas de excelência do Canto Coral também são vivenciadas, pois acreditamos na construção do conhecimento de forma integral. São muitos estudiosos na área, são muitas músicas compostas para esta formação musical, o que acrescenta conhecimento à comunidade atendida. Privilegiando o diálogo cultural, favorecendo assim a construção de um conhecimento democrático, valorizando a comunidade local. Desta forma, reforçamos o que Souza (2014, p. 95) nos diz: "Entender a música como prática social significa compreender que as exigências técnico-musicais estão ligadas às práticas de sociabilidade nos grupos, na família, na escola, na igreja e na comunidade". 


\section{CORAL VOZES DO AGRESTE E CANTAR'T (NOVA CRUZ - RN)}

Imagem 1 - Coral Vozes do Agreste e Cantar't

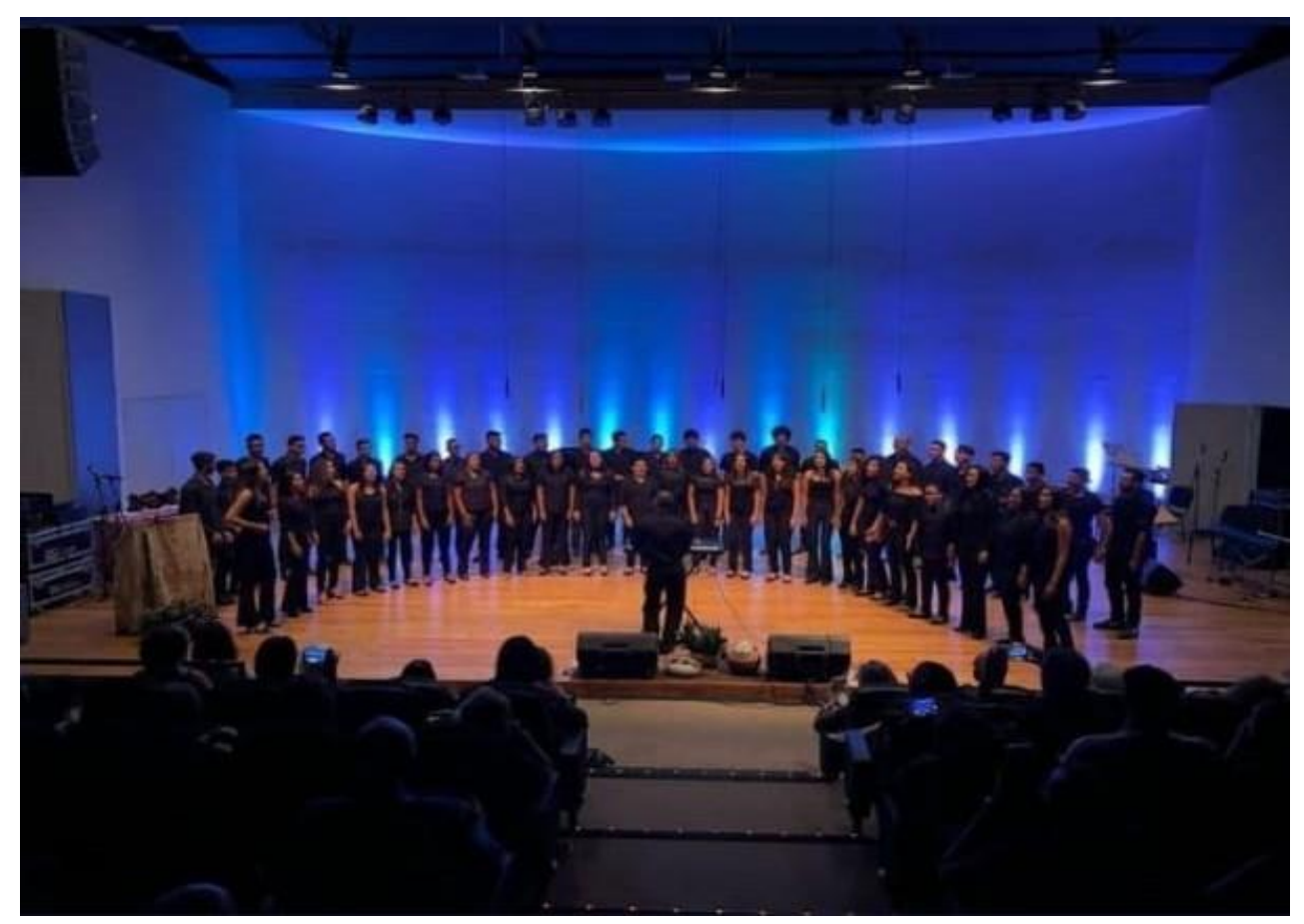

Fonte: arquivo pessoal

Os dois coros ilustrados acima, pertencem ao Núcleo de Arte e Cultura do Campus Nova Cruz. O primeiro, Vozes do Agreste, foi criado em julho de 2017; e o segundo, Cantar't, em janeiro de 2019. Em ambos, participam alunos do IFRN , pessoas da comunidade de Nova Cruz-RN e de algumas cidades circunvizinhas. Os ensaios ocorrem duas vezes por semana com cada coro e , quando há necessidade, ensaios extras com os naipes são realizados, para que aja fortalecimento e uma melhor compreensão do material sonoro, bem como, os coralistas tomem consciência do seu próprio material sonoro, diante do seu aparelho vocal, com seus limites e potencialidades.

Para a realização dos ensaios, organizamos da seguinte forma: 1) momento de relaxamento; 2) trabalho de respiração e aquecimento vocal; 3) revisão de repertório já aprendido e do gosto dos coristas; 4) repertório novo; 5) desaquecimento; 6) momento de avisos. Com essa organização, os ensaios não se tornam cansativos, e mais interativos. Acreditamos que os ensaios tendo essa organização e organograma, os participantes têm uma oportunidade de aprendizado e de montar um esquema metódico de apreensão e musicalização.

Diante disso, conforme aponta Penna (2005), uma das perspectivas da atualidade é a inter e multiculturalidade, diante da diversidade. O Canto Coral é uma instância que se encontra dentro dessa perspectiva, pois a multiplicidade e o fazer de forma ampla permitem que os 
sujeitos plurais se encontrem em contextos diversos e se compreendam dentro de espaços de ações heterogêneas. Os Coros Vozes do Agreste e Cantar't encontram-se dentro de espaços com essas características múltiplas e são multiculturais diante da diversidade do seu repertório e apresentações já realizadas. Festival de Coros da Paraíba e Festival de Coros de Pernambuco, assim como eventos sistêmicos do IFRN, a exemplo do SECITEX (Semana de Ciência, Tecnologia e Extensão), tornam-se espaços e momentos em que a diversidade de repertório e o aprendizado com outros grupos que se apresentam concomitantemente, sejam oportunidades de trocas significativas, diante desta multiculturalidade.

Outra questão, observada e trabalhada, é o próprio processo de transformação que os coralistas adquirem, através da experiência desenvolvida nos ensaios e apresentações. Conforme aponta Gainza (1988), estamos passando por momentos de intensas transformações científicas e, ainda, vários materiais e metodologias de ensino de Músicas estão sendo reinventadas, diante dos contextos sociais. A autora destaca também que o enfoque particular de um especialista da Música será substituído pelo "princípio pedagógico", pelo "objetivo" e pela "tendência" (GAINZA, 1988, p. 105). Nesse sentido, os objetivos e os princípios são instrumentos norteadores da prática do Canto Coral. Na realidade dos Coros Vozes do Agreste e Cantar't, na nossa observação, o repertório, a vontade de poder se apresentar publicamente e as apresentações com o repertório já decorado, dentre outras questões, são elementos que nos mostram o envolvimento dos participantes com a própria Música, diante dos vínculos afetivos que esta permite desenvolver.

Assim, compreendemos que os Coros Cantar't e Vozes do Agreste constituem-se como práticas significativas, diante da diversidade, das partilhas e das relações desenvolvidas pelos próprios participantes com o material sonoro, dos contextos e das particularidades multiculturais destes contextos. Para os educadores, o fazer musical plural e efetivo deve ser refletido de forma abrangente e responsável, para que ações como o Canto Coral possam se constituir como instâncias mais plausíveis para que a Música seja presente na vida dos seus participantes. 


\section{EXPERIÊNCIA IPANGUAÇU: CORAL VALE VOCALIS}

Imagem 2 - Coral Vale Vocalis

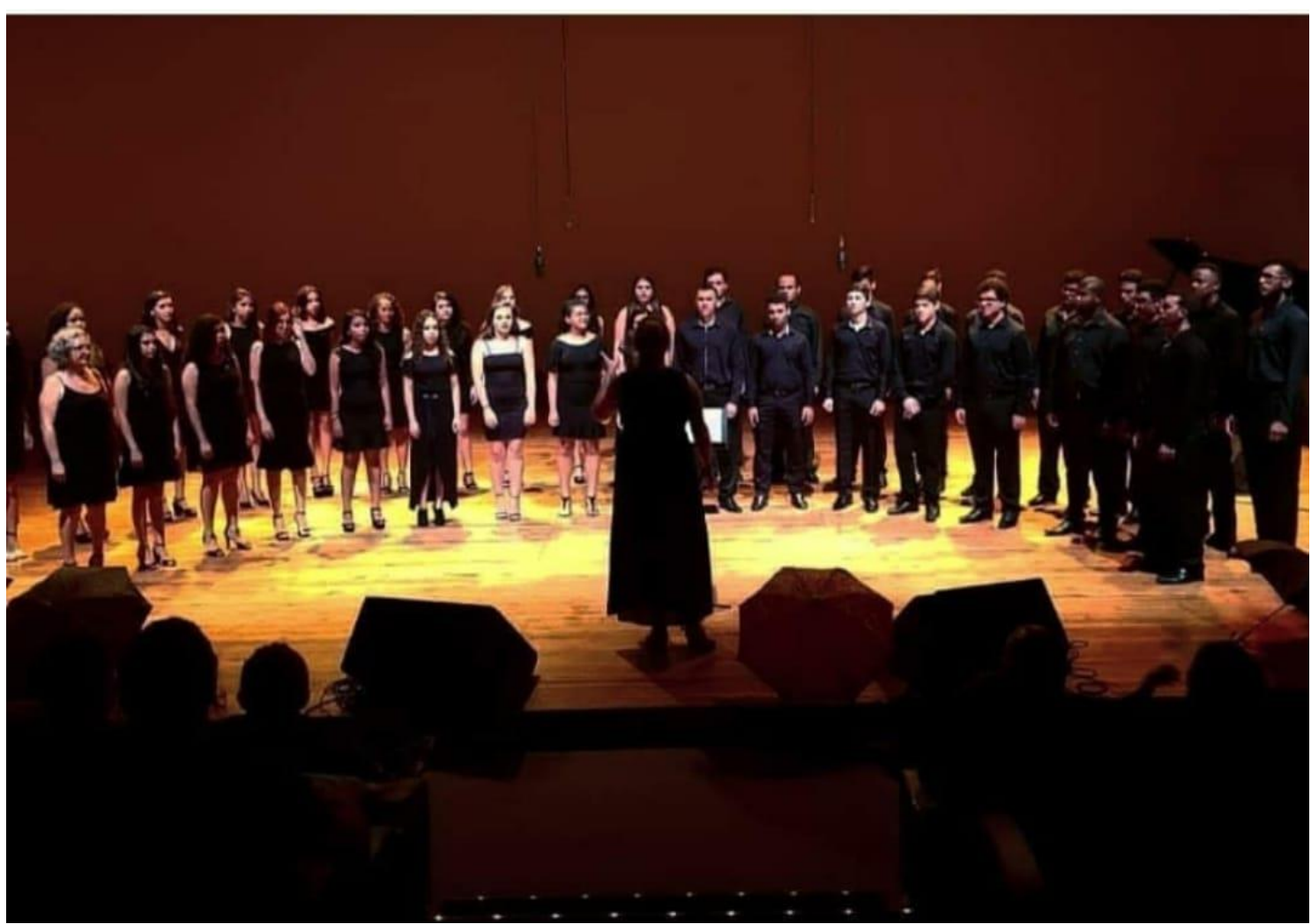

Fonte: arquivo pessoal

Ipanguaçu, cidade do Semiárido do Rio Grande do Norte, com aproximadamente 15.500 habitantes, encontra-se no centro do Estado e é uma cidade que conta como sua renda principal a fruticultura. Do ponto de vista cultural, Ipanguaçu conta com o Centro de Cultura José Coriolano Ribeiro, que oferece as seguintes atividades: Biblioteca Municipal Manoel Nunes Filho, salas para as práticas de artesanato, artes plásticas, música, dança, assim como promove concursos de fotografia. É um espaço de promoção cultural que busca valorizar a história do povo ipanguaçuense. Nesta cidade, encontramos o Instituto Federal de Educação, Ciência e Tecnologia do Rio Grande do Norte - IFRN, Campus Ipanguaçu, que além de atender Ipanguaçu, atende às demais cidades do Vale do Assu/RN. Neste ambiente educacional está à disposição da sociedade uma diversidade de estudos nas áreas de Agroecologia, Meio Ambiente, Informática e Química, nos mais variados níveis de aprendizado: Ensino Médio Integrado, Licenciatura, Tecnólogo, EJA e cursos Subsequentes, privilegiando as grandes áreas de Ensino, Extensão e Pesquisa.

Neste universo educacional está inserida a atividade musical do grupo Coral Vale Vocalis, que atende a todos os níveis de aprendizado do Instituto, bem como a comunidade 
local, pois constitui uma atividade de Extensão do campus. A experiência musical no Campus Ipanguaçu tem crescido a cada ano que passa. Bandas de rock, grupos de flauta doce, vivência de cultura popular pela prática percussiva de tambores, construção de repertórios junto aos alunos para ampla divulgação pelo campus, uma boa parcela de alunos que participam de filarmônicas mantidas pelas cidades do entorno do nosso campus. E é neste rico cenário musical que o grupo vocal Coral Vale Vocalis também marca sua presença. A atividade musical do coral surgiu em 2013 com a iniciativa do então professor de Arte/Música Gueidson Pessoa. Por motivos de remanejamento interno na Instituição, o professor Pessoa assumiu compromissos em Natal/RN. E desde 2015, eu assumi a direção do coral ${ }^{3}$.

O Coral Vale Vocalis é um espaço de aprendizado musical, visando a interação sociocultural das pessoas envolvidas, o enriquecimento do repertório do público participante, o aprendizado da linguagem coral com todas as suas sutilezas: reconhecimento e compreensão da linguagem musical, desenvolvimento do ato de ouvir o outro e ouvir-se e, principalmente, a execução de repertório adequado a esta formação musical. O grupo é uma atividade artística do Campus Ipanguaçu, do IFRN, e busca integrar alunos regularmente matriculados, servidores, terceirizados e comunidade externa ao campus. Os ensaios acontecem sempre uma vez por semana, considerando os seguintes momentos: ensaio geral (o grupo completo); e ensaios extras (manhã, tarde e/ou noite) para o estudo pormenorizado das partituras propostas, visando também o trabalho da técnica vocal dos participantes.

De acordo com Junker (1999), os grupos corais podem ser classificados nos seguintes gêneros: corais de empenho (que pertencem a instituições cujo fim não é a Música), corais religiosos (ligados às instituições religiosas), corais de escolas técnicas e superiores de Música, corais independentes (formados independentemente de instituições). O Vale Vocalis se encaixa no perfil dos corais de empenho, pois tem uma formação de pessoas com interesses em comum, com o foco na prática vocal em conjunto. Ressaltamos também que participações de eventos de cunho nacional e internacional fazem parte das atividades do Vale Vocalis, marcando presença em eventos nas cidades de Natal e João Pessoa, no Encontro Nacional de Coros em Natal/RN e Festival Paraibano de Corais em João Pessoa/PB, levando assim, para fora dos muros institucionais as atividades musicais desenvolvidas. Ademais, vale destacar que o grupo exerce suas atividades no Campus Ipanguaçu com foco nas atividades institucionais realizadas pelo IFRN, atendendo aos eventos internos, como também aos da comunidade do entorno.

\footnotetext{
${ }^{3}$ Luciana Real Limeira, uma das autoras deste capítulo.
} 


\section{CONSIDERAÇÕES FINAIS}

A prática musical por meio de coral corrobora para a aquisição de conhecimentos musicais de uma maneira ampla e democrática. Afinal, não exige maiores conhecimentos musicais, neste contexto específico, pois os coralistas têm a oportunidade de aprender Música, fazendo Música! A experiência musical destes dois campi é prova viva de que a prática, bem realizada, produz bons conhecimentos, proporcionando a todos os participantes, desde os regentes, coralistas e plateia, a oportunidade de fruição de uma atividade artística.

De acordo com Mathias (1986), podemos sim transformar uma sociedade pela Educação Musical: "Educação significa, pois, o processo de tirar de dentro de uma pessoa, ou levar para fora duma pessoa, alguma coisa que já está dentro, presente na pessoa" (MATHIAS, 1986, p. 21). Buscamos em nossas práticas trazer para fora a musicalidade de nosso coralista, visto que o resultado musical é fruto do trabalho de todos envolvidos nesse processo do Canto Coral.

A prática do Canto Coral vivenciada em espaços escolares propicia a toda comunidade acadêmica a experiência musical, além de que a oferta desta atividade artística assegura a todos a oportunidade de expressar-se com espontaneidade. Por intermédio das atividades musicais, pratica-se a desenvoltura e o cuidado com a autoestima, além de que os seus participantes têm a oportunidade de aprender e de se desenvolver via expressão artística.

As experiências acadêmicas relatadas aqui apontam para estudos futuros sobre a natureza das atividades realizadas em conjunto. Em se tratando da Música, a atenção se dirige às nuances das práticas vocais, do reconhecimento de si próprio como cantor/cantora, da habilidade de ouvir o outro e a si mesmo também. Do ponto de vista técnico, podemos pesquisar questões musicais específicas, como: a construção de repertório; a compreensão da linguagem musical para grupo; a técnica vocal adequada às idades que estão sendo trabalhadas, entre outros.

A nossa prática não se encerra aqui, registramos uma fatia de nossas experiências, que tal qual a Música, está sujeita a variações de tema, ou seja, cada grupo musical é único e cada construção de repertório é única também. Assim sendo, sempre poderão variar de acordo com a formação de cada grupo ao longo do tempo.

\section{REFERÊNCIAS}

GAINZA, Violeta Hemsy de. Estudos de psicopedagogia musical. Tradução de Beatriz A. Cannabrava. $3^{a}$ edição. São Paulo: Summus, 1998. 
IPANGUAÇU. Gestão para todos. Disponível em: http://ipanguacu.rn.gov.br/. Acesso em: 20 de fevereiro, 2020.

JUNKER, David. O movimento do canto coral no Brasil: breve perspectiva administrativa e histórica; In: Anais do Congresso da ANPPOM. XI Encontro da Associação Nacional de Pesquisa e Pós-Graduação em Música. Campinas: 1999. p. 2-8. Disponível em: antigo.anppom.com.br/anais. Acesso em: 13 de fevereiro, 2020.

JUNKER, David. Panoramas da regência coral: Coro sinfônico comunitário da UnB: uma história de vozes e vidas. Brasília: Escritório de Histórias, 2010.

MATHIAS, Nelson. Coral, um canto apaixonante. Brasília: Musimed, 1986.

PENNA, Maura. Poéticas musicais e práticas sociais: reflexões sobre a educação musical diante da diversidade. Revista da ABEM, n. 13, p. 7-16, 2005.

PENNA, Maura. DÓ, RÉ, MI, FÁ e muito mais: discutindo o que é Música. In: PENNA, Maura (Org.). Música(s) e seu ensino. $2^{\text {a }}$ ed. Porto Alegre: Sulina, 2010.

PEREIRA, Éliton; VASCONCELOS, Miriã. O Processo de Socialização no Canto Coral: um estudo sobre as dimensões pessoal, interpessoal e comunitária. Música Hodie, vol. 07, n. 01, 2007.

QUEIROZ, Luis Ricardo Silva. A Música como Fenômeno Sócio-Cultural: perspectivas para uma educação musical abrangente. In: Contexturas: o ensino das artes em diferentes espaços, cap. 2, p. 49-65. João Pessoa: Editora Universitária/UFPB, 2005.

SOUZA, Jusamara. Educação Musical e Práticas Sociais. Revista da ABEM, n. 10, p. 7-11, 2004

SOUZA, Jusamara. Música, educação e vida cotidiana: apontamento de uma sociografia musical. Educar em Revista, Curitiba, Editora UFPR, n. 53, p. 91-111, julho/setembro, 2014. 


\title{
https://doi.org/10.36470/famen.2020.14c5 \\ EDUCAÇÃO E SAÚDE: PRÁXIS DE APRENDIZAGEM NO AMBIENTE ESCOLAR
}

\author{
Francisco Marcos da Silva Figueiredo ${ }^{1}$ \\ Hellyegenes de Oliveira ${ }^{2}$
}

\section{RESUMO}

Para abordar a escola e as salas de aula como um espaço de saúde dentro dos processos de aprendizagem, partimos da concepção de que ser saudável é ter a possibilidade de avaliar a realidade, reconhecendo e dando visibilidade às suas potencialidades, partindo do que já se possui para construir um cenário melhor. Ser saudável não significa estar acima dos problemas cotidianos, mas conseguir problematizar uma situação percebendo como o entorno atua sobre ela. Nada está solto, descontextualizado, por isso o espaço escolar, entendido como saudável, é considerado dentro de um contexto maior: a comunidade na qual está inserido e a sociedade que o estrutura. Norteados por estas concepções, o presente capítulo, de cunho reflexivo e bibliográfico, objetiva destacar a importância da saúde e a da educação para o desenvolvimento do processo de compreensão entre o professor, o aluno e os diversos agentes que compõem o espaço educacional como um todo. Os resultados do estudo revelam que uma escola saudável e ativa considera todos os atores que a compõem e o cenário que a circunda, valorizando os recursos disponíveis, as ações criativas e os resultados positivos de ações pedagógicas interdisciplinares.

Palavras-chave: Escola. Saúde. Aprendizagem. Educação. Práxis.

\section{INTRODUÇÃO}

É necessário compreendermos e discutirmos as concepções que subsidiam as ações de saúde como práticas pedagógicas, tornando-as claras para todos os envolvidos. Para Saviani (2005), as concepções pedagógicas são as diferentes maneiras pelas quais a educação é compreendida, teorizada e praticada, denotando o modo de operar e de realizar o ato educativo. Apesar de as escolas não se sentirem responsáveis pela prática da saúde em seus ambientes, é inegável o seu papel em temas ligados à saúde por ser cenário propício para lidar com as questões que envolvem especialmente os alunos, inclusive em ambiente social e familiar.

Os programas de educação em saúde direcionados às crianças e adolescentes são, em geral, realizados nas escolas. Embora educar para a saúde seja responsabilidade de diferentes segmentos, a escola é a instituição privilegiada, já que pode se transformar num espaço genuíno de promoção da saúde. O sistema escolar deve ser respeitado em sua função e missão de desafiador de novos conhecimentos, para que os indivíduos sejam, efetivamente, mais sábios.

\footnotetext{
1 Especialista em Auditoria em Saúde e mestrando em Saúde Coletiva da Universidade Católica de Santos (UNISANTOS). E-mail: maarcos2811@gmail.com

2 Especialista em Psicopedagogia e EJA. Mestrando em Educação pela Universidade do Sul de Santa Catarina (UNISUL). E-mail: hellyegenes@ @otmail.com
} 
Entretanto, para que isso seja possível é necessário que as famílias disponham de tempo, vontade e dedicação à sua missão de promotoras da educação.

Para que ocorra essa conscientização dos alunos e das famílias, é preciso que, em um primeiro momento, a família eduque seus filhos, para que, posteriormente, a escola possa fortalecer um processo produtivo de educação, auxiliando na prevenção de enfermidades desnecessárias.

Existe um consenso sobre o importante papel das ações de promoção da saúde e de educação em saúde desenvolvidas dentro das escolas, com o intuito de garantir uma formação integral dos alunos. Comportamentos espontâneos não asseguram a saúde das pessoas, por isso existe a necessidade da instrução formal obrigatória que incorpore a saúde entre seus objetivos. O ensino de saúde na escola ainda é centrado nos aspectos biológicos e também ainda é, principalmente, trabalhado nos conteúdos de Ciências Naturais.

Os projetos de educação em saúde na escola, em sua maior parte, são realizados nas aulas de Ciências ou de Biologia, muito embora os assuntos estejam relacionados ao tema transversal Saúde, ou seja, tema a ser trabalhado em todas as disciplinas do currículo escolar. Destaca-se assim que o papel da escola vem se tornando cada vez mais importante na formação de hábitos saudáveis.

Nesse ambiente, deve haver espaço para educadores e alunos discutirem questões sobre saúde, mas para isso é fundamental que os educadores tenham formação e conhecimento suficiente. A educação para a saúde pode ser compreendida como um motivo para o progresso e tutela à saúde e tática para o triunfo dos direitos da cidadania.

Contudo, vale salientar que apenas a escola não poderá fazer com que os alunos adquiram saúde. O que pode ser feito pelo ambiente escolar é o fornecimento de mecanismos, tais como: a implementação de políticas escolares de promoção a uma vida saudável, bem como a constituição de ambientes benignos e produtivos para este processo; capacitações e orientações da comunidade escolar para o engrandecimento das habilidades individuais e coletivas para a reorientação dos serviços de saúde; e orientações aos alunos que propiciem uma vida saudável.

Não é de hoje que se reconhece o vínculo entre a saúde e a educação. Sob o argumento da ligação entre as duas áreas, existe algum consenso: bons níveis de educação estão relacionados a uma população mais saudável, assim como uma população saudável tem maiores possibilidades de adquirir conhecimento da educação formal e informal. A escola representa um importante local para o encontro entre a saúde e a educação abrigando amplas possibilidades e iniciativas, que têm sido identificadas como Saúde Escolar, cujo objetivo é proporcionar condições adequadas à realização do processo educacional. 
Nessa perspectiva, o presente capítulo promove uma reflexão acerca da construção dos processos de conscientização da saúde dentre o espaço educacional, visando sua aplicação não apenas na escola, mas também na família e por todos os agentes que atuam direta ou indiretamente com os processos de aprendizagem dos alunos. Por meio de uma pesquisa qualitativa, este trabalho busca diversas significações acerca do assunto elencado. Sobre isso, Minayo (2001, p.14) afirma:

[...] a pesquisa qualitativa trabalha com o universo de significados, motivos, aspirações, crenças, valores e atitudes, o que corresponde a um espaço mais profundo das relações, dos processos e dos fenômenos que não podem ser reduzidos à operacionalização de variáveis.

A pesquisa qualitativa responde a questões muito particulares, uma vez que se preocupa com um nível de realidade que não pode ser quantificado, ou seja, ela trabalha com o universo de significados e conceitos que pode ser assimilado a um processo mais aprofundado no mundo das relações e dos significados das ações humanas.

Em suma, acreditamos na relevância desta pesquisa por enfatizarmos que a sensibilização e a formação do corpo docente têm importância fundamental para que a Educação em Saúde exista de fato e que seja bem trabalhada dentro das escolas, como também por defendermos que a implementação de uma estratégia educativa no campo da saúde requer, primeiramente, que os docentes tenham conhecimento e interesse a respeito do tema que pretendem desenvolver.

\section{A IMPORTÂNCIA DA SAÚDE NOS CONTEXTOS EDUCACIONAIS}

Políticas e programas públicos de saúde e de educação são fundamentais para a formação cidadã e para a melhoria da qualidade de vida e saúde da população. Como posto anteriormente, melhores níveis de educação estão relacionados a uma população mais saudável, o que possibilita maiores chances na retenção de conhecimentos ao longo do processo de aprendizagem. Para que o trabalho pedagógico e social obtenha resultados satisfatórios no processo de aprendizagem, as ações dos professores devem estar vinculadas aos mais variados segmentos: do projeto pedagógico da unidade escolar à realidade educacional em que os alunos estão inseridos.

Vivenciamos um momento no qual o espaço escolar não pode mais restringir-se ao trabalho isolado da sala de aula, principalmente no que se diz respeito aos processos de conscientização dos processos de saúde. Os Parâmetros Curriculares Nacionais (PCN), que 
constituem o plano curricular oficial para o ensino fundamental brasileiro, abrangem, além das disciplinas tradicionais, a saúde como um dos seis temas transversais, somando-se a ética, pluralidade cultural, meio ambiente, orientação sexual e trabalho e consumo (BRASIL, 1997). Temas eleitos por envolverem problemáticas sociais atuais e urgentes, consideradas de abrangência nacional e, até mesmo, de caráter universal (BRASIL, 1997).

Essa transversalidade pressupõe um tratamento integrado das áreas e um compromisso das relações interpessoais e sociais escolares com as questões que estão envolvidas nos temas, a fim de que haja uma coerência entre os valores experimentados na vivência que a escola propicia aos alunos e o contato intelectual com tais valores (BRASIL, 1997).

Nesta concepção, a construção de práticas integradas envolvendo a educação e saúde tem incentivado a promoção da saúde no ambiente escolar. Para o sucesso da educação em saúde nas escolas, são necessárias mudanças significativas nos sistemas de saúde e de educação, através de novas estratégias e diversificadas formas de gestão em ambos os Ministérios. Assim, impõem-se formas atualizadas de operacionalizar a saúde escolar e de avaliar seu impacto na sociedade, tendo sempre em conta que a escola deve continuar a ser a grande promotora da saúde (PORTUGAL, 2006a).

Para o supracitado autor, uma escola que se propõe a promover a saúde deve mobilizar a participação direta da comunidade, desde as decisões sobre o projeto, ao envolvimento da própria escola, dos serviços de saúde, da comunidade de pais, dos voluntários, das empresas, dos parceiros diversos, até a sua execução e avaliação, conscientizando a comunidade quanto às principais ameaças à saúde e segurança das crianças no meio escolar (PORTUGAL, 2006b).

A escola, na procura permanente de um ambiente mais saudável para as crianças, deverá assegurar saneamento básico, água de qualidade, ambiente de suporte à atividade física e à mobilidade segura, ar interior e exterior livres de poluição, assim como reduzir a exposição das crianças aos riscos físicos, químicos e biológicos (WHO, 2003).

Ademais, a saúde e a educação devem ser tratadas como parte de uma formação ampla para a cidadania e o usufruto pleno dos direitos humanos. Para isso, é necessário, conforme tratam os PCN, que cada escola formule seu projeto educacional, compartilhado por toda a equipe, para que a melhoria da qualidade da educação resulte da corresponsabilidade entre todos os educadores (BRASIL, 1997).

A adoção do conceito de promoção da saúde como elemento redirecionador das políticas do Ministério da Saúde impõe a necessidade de sistematizar, em conformidade com os princípios do Sistema Único de Saúde (SUS), propostas intersetoriais que provoquem ou reforcem o desenvolvimento de ações com os mais diferentes setores. 
O setor educacional, dada sua capilaridade e abrangência, é um aliado importante para a concretização de ações de promoção da saúde voltadas para o fortalecimento das capacidades dos indivíduos, para a tomada de decisões favoráveis à sua saúde e à comunidade, para a criação de ambientes saudáveis e para a consolidação de uma política intersetorial voltada para a qualidade de vida, pautada no respeito ao indivíduo e tendo como foco a construção de uma nova cultura da saúde.

Assim, é relevante programar estratégias integradas de aproximação da saúde com o sistema educacional, suas unidades de ensino e suas representações políticas, sem deixar de considerar como essencial a formação e qualificação docentes, na expectativa de que essas estratégias fomentem a adoção de hábitos de vida mais saudáveis e promovam mudanças individuais e organizacionais significativas.

Diante disso, reconhecemos que, além da escola ter uma função pedagógica específica, tem uma função social e política voltada para a transformação da sociedade, relacionada ao exercício da cidadania e ao acesso às oportunidades de desenvolvimento e de aprendizagem, razões que justificam ações voltadas para a comunidade escolar para dar concretude às propostas de promoção da saúde.

\section{AÇÕES DE SAÚDE QUE CONTRIBUEM COM O ESPAÇO EDUCACIONAL}

Os espaços educacionais necessitam de ações que proponham uma nova perspectiva educacional principalmente no que se diz respeito aos processos da saúde, motivada por uma nova ordem para estabelecer um ambiente educacional que se caracterize pela divisão das responsabilidades entre sociedade e instituição escolar na formação de alunos-cidadãos.

A escola além de transmitir conhecimentos sobre a saúde, organizados em disciplinas, deve, também, educar e desenvolver valores e posturas críticas relacionadas à realidade social e aos estilos de vida, em processos de aquisição de competências que sustentem as aprendizagens ao longo da vida e que favoreçam a autonomia e o empoderamento para a promoção da saúde.

Para tanto, o que parecia ser única e exclusivamente responsabilidade das escolas deve ser dividido entre a escola, família e sociedade em um contexto mais amplo e justo, corrigindo as falhas desde a origem das causas dos problemas sociais que afetam o sistema educacional na formação dos alunos. Nesse viés, as escolas devem propiciar um espaço que contemple o ambiente familiar da criança, para uma educação de qualidade e consequentemente um espaço múltiplo de aprendizagem e afetividade. 
Sobre esses posicionamentos, Tiba (1996, p.140), nos afirma que "O ambiente escolar deve ser de uma instituição que complete o ambiente familiar do educando os quais devem ser agradáveis e geradores de afeto. Os pais e a escola devem ter princípio muito próximos para o benefício do filho/aluno".

Diante disso, observa-se a necessidade de constituir espaços que sirvam de base para a construção da proximidade entre família e escola, a fim de efetivar o processo de promoção à saúde e de promover ações, como: reuniões de pais/responsáveis em horários convenientes a maioria da comunidade escolar; acompanhamento dos pais/responsáveis no processo de aprendizagem de seus filhos; inserção de atividades que viabilizem a saúde, o bem estar e o desenvolvimento social da comunidade; e exposição das ações de saúde e das produções dos alunos.

Essas ações promoverão, além da aproximação família-escola, um trabalho integrado/globalizado. Acerca da necessidade de uma união entre a escola, sociedade e família para um desenvolvimento satisfatório do educando, Ikeda (2009, p.58) explica:

A escola ocorre tanto na escola como em casa. No entanto, quando as pessoas pensam em "educação" comumente visualizam o prédio escolar e as salas de aulas. Pouquíssima atenção é dada para cultivar o humanismo que também deveria proporcionar no lar.

Esta constitutiva não se apresenta como uma tarefa simples, mas sim como algo que exija responsabilidade, comprometimento e ações realmente efetivas que tenham qualidade, objetivos e métodos eficazes na busca pela formação e educação de crianças e jovens que constituem a sociedade brasileira, uma vez que a educação é imprescindível para conscientizar as pessoas de sua participação ativa, através de ações educativas. Assim sendo, acreditamos que a conscientização dos cidadãos em relação às ações educacionais vigentes seja um caminho viável para o pleno exercício da cidadania, a fim de formar cidadãos participantes e conscientes de seu papel na sociedade.

Ademais, ensinar é uma atividade complexa que pressupõe dedicação e entusiasmo, busca pelo conhecimento e desejo em transmiti-lo. Por isso, é imprescindível que haja maior compromisso com a formação dos docentes, através de investimentos financeiros, que propiciem: qualidade na formação iniciada e continuada ofertada aos professores; inserção de profissionais qualificados no mundo do trabalho; oportunidade de atuação interdisciplinar entre diferentes setores da saúde e educação.

Ao entenderem essa necessidade, os Ministérios da Educação e da Saúde publicaram, em 2007, o Decreto n 6.286, instituindo o Programa Saúde na Escola (PSE). Segundo o 
Decreto Interministerial, o PSE constitui estratégia para a integração e a articulação permanente entre as políticas e ações de educação e de saúde, com a participação da comunidade escolar, envolvendo as equipes de saúde da família e da educação básica. Além disso, as ações em saúde previstas no âmbito do PSE devem considerar a atenção, promoção, prevenção e assistência, e serem desenvolvidas articuladamente com a rede de educação pública básica e em conformidade com os princípios e diretrizes do Sistema Único de Saúde (BRASIL, 2007).

Desde então, surgiram ações em torno do desenvolvimento das ações de saúde no âmbito educacional, e o Programa Saúde na Escola é um dos que mais ganham espaço dentre os ambientes educacionais atualmente. Contribuiu para que a educação em saúde não estivesse somente vinculada à exposição e verificação da apreensão de conhecimentos em saúde, mas que ultrapassasse limites, alcançando a avaliação de práticas de saúde, a identificação de indicadores efetivos de doenças que pudessem comprometer o aprendizado do aluno.

A Escola, ao constituir-se como um espaço seguro e saudável, deve facilitar a adoção de comportamentos mais saudáveis, estabelecendo-se numa posição ideal para promover e manter a saúde da comunidade educativa e da comunidade envolvente (PORTUGAL, 2006a). Para tanto, professores e gestores devem ser preparados para apoiar o processo de promoção da saúde em meio escolar, para partilhar saberes, e para encontrar pontos de convergência, no desafio da viabilização da saúde positiva para todos os atores envolvidos.

\section{INTEGRAÇÃO ENTRE FAMÍLIA E SOCIEDADE NO ESPAÇO EDUCACIONAL}

Promover saúde é tocar nas diferentes dimensões humanas, é considerar a afetividade, a amorosidade, a capacidade criadora e a busca da felicidade como igualmente relevantes e indissociáveis das demais dimensões. Por isso, a promoção da saúde é vivencial e é associada ao sentido de viver e aos saberes acumulados pela ciência e pelas tradições culturais locais e universais.

Criar momentos de debates sobre fatores desfavoráveis à saúde presentes nas realidades dos alunos e da comunidade escolar, mobilizando projetos, ações, com relação à saúde individual e coletiva, considerando a saúde sob seus diferentes aspectos, é possível quando se favorece o desencadear do desejo de conhecer e utilizar os recursos da própria localidade voltados para a promoção da saúde e para a atenção à doença.

Redes de apoio, nas mais diferentes formas e instâncias, são fundamentais para essa promoção: conselhos de saúde, de direitos da mulher, de cidadania, de defesa da criança e do adolescente, tutelares, associações de moradores, de pescadores, de domésticas, de professores, 
grêmios estudantis, movimentos ligados a partidos políticos ou às igrejas, dentre outros. Mobilizar recursos significa envolver essas redes ou setores governamentais e não governamentais em ações institucionais no campo da saúde.

Tanto para o educando quanto para o educador, o exercício de troca, de diálogo, de embates, de compartilhamento de saberes e fazeres, da crítica da realidade possibilitará a construção da autonomia, da solidariedade e da cooperação cidadã e se manifestará na redefinição dos eixos temáticos para as diferentes áreas e na eleição das abordagens e dos conteúdos.

Essa mobilização de recursos, que, em um primeiro momento, tem o local como ponto de partida, vai sendo alargada e alcançando dimensões mais amplas e incorporando outras redes do município, do estado, da região, do País, do continente, tomando, na perspectiva mais global, uma dimensão planetária.

A família, sendo a base de uma formação completa do indivíduo, tem papel decisivo na formação de caráter, deve ter participação direta na educação das crianças. Portanto, é fundamental que aconteça essa parceria entre escola e família, e que juntos possam alcançar o objetivo em comum: formar cidadãos de bem para o mundo atual.

Conforme Jardim (2006), a relação escola e família vem sendo muito discutida nos últimos tempos. A grande dúvida é saber os limites entre os deveres da família e os da escola. Como se sabe, não é a escola e sim a família que proporciona as primeiras experiências educacionais à criança.

\footnotetext{
A família é o berço da formação de regras, princípios e valores, outras instituições assim como a escola, possuem também papel muito importante nesta formação moral, a escola se organizando de forma democrática, oportunizando uma vivência cidadã. Dessa forma, promovem o nascimento crescimento do respeito mútuo e o desenvolvimento da autonomia, ingrediente para formação moral (JARDIM, 2006, p. 34).
}

É de grande interesse das escolas que esta interação ocorra, pois se compreende que é seu papel promover tal interação, garantindo uma troca de informações e de ideias, orientando as famílias e mostrando o quanto é importante sua participação na educação das crianças. Contudo, para que ocorra o aprendizado é preciso uma parceria entre o educador, uma participação efetiva das famílias na vida escolar da criança, , respeitando os limites de cada um e sua privacidade.

Apesar de ambas as instituições terem papel importantíssimo no crescimento e desenvolvimento das crianças, é imprescindível que cada entenda e execute o seu papel nesse 
processo educacional. Conforme Parolin (2008), uma boa relação entre essas partes é relevante, uma vez que proporcionará, tanto à escola quanto à família, maiores chances de cumprir seus papéis:

Destaco que o papel da família na formação e nas aprendizagens das crianças e jovens é impar. Nenhuma escola por melhor que seja, consegue substituir a família. Por outro lado, destaco também que a função de escola na vida da criança é igualmente impar. Mesmo que as famílias se esmerem em serem educadoras, o aspecto socializador do conhecimento e das relações não é adequadamente contemplado em ambientes domésticos (PAROLIN, 2008, p.1)

Percebe-se assim que a ação educativa é de responsabilidade maior da família, e nem nenhuma outra instituição possui condições de substituir. No entanto, os métodos de ensino também precisam ser revistos constantemente, visto que as ações pedagógicas que parecem absolutas hoje, podem não ter mais o mesmo efeito positivo no ano seguinte, devido às constantes mudanças e diferentes formas de transmissão de conhecimento que as comunidades vivenciam diariamente. Portanto, o professor deve figurar como um mediador de conhecimento e, sempre que possível, motivar a interdisciplinaridade.

\section{CONSIDERAÇÕES FINAIS}

Refletir sobre educação em saúde implica na observação de inúmeros aspectos relevantes sobre suas origens, implicações e maneiras de se fazer com que se efetive, garantindo melhor assistência de saúde à população.

Nesse contexto, possui raízes em teorias distintas e se relaciona com temas relevados na Reforma Sanitária e nas conferências de saúde e encontros internacionais que também versaram sobre o assunto.

Dentro deste contexto, articulando-se a educação escolar à promoção da saúde percebese certo mecanismo de fortalecimento e implantação de política mais transversal, integrada e intersetorial, que propõe a articulação entre os serviços de saúde, a comunidade, às iniciativas pública e privada, além do próprio cidadão na proposição de ações que busquem bem-estar e qualidade de vida.

Uma das formas de se promover saúde é incentivar práticas de vida saudáveis, através do processo de educação em saúde, no qual se oportuniza o compartilhamento de saberes dos mais variados possíveis na busca de soluções para diversas problemáticas vivenciadas no cotidiano da comunidade escolar. 
Ações educativas podem visar à sensibilização e/ou a conscientização sobre algum problema de saúde, ou ações que possam evitar o surgimento de males à clientela. Nesse sentido, não se pode deixar de lembrar o quanto as ações preventivas são mais vantajosas do que as ações curativistas, tanto do ponto de vista econômico, quanto do ponto de vista assistencial, uma vez que podem diminuir a incidência de doenças e reduzir o número de pacientes que buscam serviços de maior complexidade, mais dispendiosos e, às vezes, menos efetivos.

De todo modo, a fusão escola- sociedade- saúde deve permanecer em sintonia ao longo do processo de ensino e aprendizagem, no intuito de assegurar uma formação integral do aluno. Para tanto, é necessário o acompanhamento da família, dando apoio às ações pedagógicas propostas pela escola, e suporte ao professor. Pais, mestres e gestores unidos em prol de uma educação significativa e transformadora. E o aluno, ao perceber o empenho dessas partes, se posicionará na direção do aprendizado.

Ademais, é necessário que as famílias criem o hábito de: participar da vida escolar das crianças; analisar os processos educativos que dizem respeito à melhoria da saúde dos alunos; valorizar toda a colaboração advinda do espaço escolar; perceber a importância de se relacionar com a escola, como também com o espaço social em que a criança está situada. No intuito de incentivar uma educação de qualidade voltada para os princípios sociais e educacionais, assim como promover a conscientização social, que parece ser a chave primordial para o processo de aprendizagem efetiva.

\section{REFERÊNCIAS}

BRASIL. Ministério da Educação e do Desporto, Secretaria de Educação Fundamental. Parâmetros Curriculares Nacionais. Brasília: MEC/SEF, 1997.

BRASIL. Decreto $n^{\circ} 6.286$ de 05 de dezembro de 2007. Institui o Programa Saúde na Escola - PSE. Diário Oficial [da] União. Brasília, DF. 06 de dez. 2007. Disponível em: <http://bvsms.saude.gov.br/bvs/publicacoes/dec_6286_05122007.pdf> Acesso em 28 de Abril de 2020.

FONSECA, J. J. S. Metodologia da pesquisa científica. Fortaleza: UEC, 2002.

GIL, A. C. Como elaborar projetos de pesquisa. 4. ed. São Paulo: Atlas, 2007.

IKEDA, Daisaku. Algumas considerações do século XXI. São Paulo: Editora Brasil Seikyo, 2006. 
JARDIM, A. P. Relação entre Família e Escola: Proposta de Ação no Processo Ensino Aprendizagem. Presidente Prudente: Unoeste, 2006.

LIBÂNEO, Jose Carlos. Democratização de escola pública: a pedagogia critica social dos conteúdos. São Paulo: Loyola, 1985.

Educação Escolar: Politicas, estrutura e Organização. [s.l.: s.n.]: 2009.

MARCONI, Marina de Andrade; LAKATOS, Eva Maria. Metodologia Cientifica. 5. ed. São Paulo: Atlas, 2003.

MINAYO, M. C. S. O desafio do conhecimento: pesquisa qualitativa em saúde. São Paulo: HUCITEC, 2001.

PAROLIN, Isabel. Relação Família e Escola. Revista atividades e experiências. Jul., 2008.

PORTUGAL. Ministério da Saúde. Direção Geral da Saúde. Divisão de Saúde Escolar. Programa Nacional de Saúde Escolar. Despacho no 12.045/2006 (2 $2^{\mathrm{a}}$ série). Publicado no Diário da República n ${ }^{\circ} 110$ de 7 de junho 2006 a.

Ministério da Saúde. Direção Geral da Saúde. Divisão de Saúde Escolar. Avaliação do Programa de Saúde Escolar Ano letivo 2004/05 - Relatório. Portugal: Ministério da Saúde, 2006 b.

SAVIANI, Dermeval. As concepções pedagógicas na história da educação brasileira. Texto elaborado no âmbito do projeto de pesquisa: "O espaço acadêmico da pedagogia no Brasil." Campinas, 2005.

Disponível em: http://www.histedlbr.fe.unicamp.br/navegando/artigos_pdf/Dermeval_Saviani_artigo.pdf. Acesso em: 27 de Abril de 2020.

TIBA, Içami. Disciplina, limite na medida certa. 1.ed. São Paulo: Editora Gente, 1996.

WHO. UNESCO. UNICEF. EDC. Promoting physical activity in schools: an important element of a health - promoting school. WHO information series on school health; document 12. 2003. 


\title{
A EDUCAÇÃO COMEÇA NO VENTRE E A DEMOCRACIA NO COLO DA MÃE
}

\author{
Maria José Rocha Lima ${ }^{1}$
}

\begin{abstract}
RESUMO
Este trabalho reúne as decisões mais recentes que ocorreram no Brasil para definir a legislação, políticas e programas em favor da primeira infância. Na introdução, foi feita uma revisão dos argumentos e evidências resultantes de diversas ciências, que sustentam a importância e reorientação das políticas para a Educação Infantil e na primeira infância. Na primeira parte, foi apresentada a evolução das medidas legislativas aprovadas no Brasil, para aplicação na política de Educação Infantil, na primeira infância, ressaltando os avanços e perspectivas. Na segunda parte, foram descritas as evidências científicas, fruto de estudos divulgados pelo Comitê Científico do Núcleo Ciência Pela Infância, da Universidade de Harvard (2015), sobre o Impacto do Desenvolvimento na Primeira Infância para a Aprendizagem. Além dos estudos do cientista James Heckman, vencedor do Prêmio Nobel de Economia no ano 2000, que realizou uma das experiências de maior repercussão mundial nessa temática. $\mathrm{Na}$ terceira parte, demos voz ao cientista Zeljko Loparic, maior especialista brasileiro nos estudos da obra do pediatra e psicanalista inglês Donald Woods Winnicott, na qual apresenta evidências de que as relações sociais começam na maternagem, na relação mãe-bebê. Conclui analisando os compromissos estabelecidos pelo governo brasileiro na aplicação das políticas pela primeira infância para a superação das desigualdades sociais.
\end{abstract}

Palavras-chave: Primeira Infância. Educação Infantil. Legislação. Políticas Públicas. Democracia.

\section{INTRODUÇÃO}

No Brasil, é absolutamente inédita e recente a política de educação infantil influenciada por evidências científicas resultantes das pesquisas sobre crianças pequenas em várias áreas das ciências humanas, sociais, médicas e, particularmente, nas mais recentes descobertas no campo da neurociência. Estas descobertas das ciências sobre o desenvolvimento infantil na Primeira Infância constituem uma das razões mais eloquentes para a defesa da educação infantil como direito fundamental. Nessa fase da Primeira Infância, observou-se que o desenvolvimento cerebral é intenso; é possível estabelecer até 700 novas conexões neuronais por segundo, praticamente o dobro de sinapses executadas aos dez anos de idade, de acordo com estudos feitos pela Academia Nacional de Ciências dos Estados Unidos (2015).

Estudo divulgado pelo Comitê Científico do Núcleo Ciência Pela Infância, da Universidade de Harvard (2015), sobre o Impacto do Desenvolvimento na Primeira Infância para a Aprendizagem, mostra que nesse período as funções cognitivas mais especializadas como atenção, memória, planejamento, raciocínio e juízo crítico começam a se desenvolver na

\footnotetext{
${ }^{1}$ Mestre em Educação pela Universidade Federal da Bahia (UFBA). E-mail: zezerochalima@ hotmail.com
} 
primeira infância por meio de habilidades, como controle de impulsos, a capacidade de redirecionar atenção e de lembrar regras. Os estudos apontam, ainda, impressionantes mudanças que ocorrem nos primeiros cinco a seis anos de vida dos seres humanos, que incapazes de falar, locomover-se e organizar-se, ao se relacionar com o mundo ao redor, de maneira construtiva, receptiva e positiva, passam a mover-se, comunicar-se através de várias linguagens, criando, transformando e afetando suas próprias circunstâncias de interação com pessoas, eventos e lugares.

Nunca deveríamos ter negligenciado a atenção e educação do bebê na Primeira Infância, uma vez que pelas próprias características biológicas, o bebê humano nasce inacabado e estruturado para aprender, portanto dependente do outro para a sua sobrevivência física e psíquica. A educação para o homo sapiens é uma imposição porque somos biologicamente sociais, dependentes do outro ao nascer e nos caracterizamos por possuir duas aptidões estupendas, que são a plasticidade do cérebro e a aptidão para aprender. Por tudo isto, a educação na Primeira Infância deve ser positivada como um Direito Fundamental, que não dependa da vontade de agentes públicos de plantão.

\section{PRIMEIRA INFÂNCIA NA LEI: AVANÇOS E PERSPECTIVAS}

$\mathrm{O}$ atendimento institucional à criança pequena apresentou, no decorrer da história, concepções bastante divergentes sobre a sua função social. A maioria dessas instituições de atendimento nasceu com a finalidade de atender exclusivamente às crianças pobres.

As creches e programas de pré-escolas sempre constituíram instituições estratégicas para enfrentamento da pobreza e resolver os problemas das crianças em contextos de vulnerabilidades, o que justificava em grande medida o baixo investimento, com a destinação de recursos orçamentários, quase sempre, irrisórios; em instalações precárias; sem exigência de profissionais qualificados e com um número muito desproporcional de crianças, sob a responsabilidade de poucos adultos.

Entre as estratégias para justificar a educação pré-escolar estava aquela de educação compensatória, para reduzir os altos índices de evasão e repetências das crianças pobres ao ingressarem no ensino fundamental.

O estabelecimento de uma política nacional para a infância ainda é bem recente no Brasil, como um investimento social que considera as crianças como sujeitos de direitos, cidadãs em processo de desenvolvimento. Uma política nacional, que se remete à indispensável integração do estado e da sociedade civil, como coparticipantes das famílias no cuidado e 
educação de seus filhos entre 0 a 6 anos. Embora os intelectuais que subscreveram o Manifesto dos Pioneiros da Educação Nova de 1932, dentre eles Anísio Teixeira, já defendessem claramente a educação infantil como uma etapa da educação, isto só se positivou na Constituição de 1988, que foi considerada um marco na conquista de vitórias importantes para a garantia de direitos para a população infanto-juvenil e, posteriormente, consolidadas no Estatuto da Criança e do Adolescente.

Em 1996, a Lei de Diretrizes Básicas da Educação (LDB) estabeleceu a educação infantil como a primeira etapa da educação básica² .

Em 2006, registra-se a maior das conquistas das últimas décadas, senão da história, da educação infantil, com a aprovação da Emenda Constitucional n ${ }^{\circ} 53$, que criou o Fundo de Manutenção e Desenvolvimento da Educação Básica e de Valorização dos Profissionais da Educação (FUNDEB) e, em seu art. $7^{\circ}$, inciso XXV, estabelece a assistência gratuita aos filhos e dependentes desde o nascimento até cinco anos de idade em creches e pré-escolas, e no Art. 208, inciso IV, assegurando a oferta da educação infantil, em creche e pré-escola, às crianças até 5 (cinco) anos de idade, oferta que se tornou obrigatória para crianças de 4 e 5 anos, desde 2016.

Em 2009, ocorreu mais uma importante conquista a aprovação da Emenda Constitucional $\mathrm{n}^{\circ} 59$, que tornou obrigatória a oferta da educação básica para todos os brasileiros. A Constituição Federal (CF) passou a vigorar com as seguintes alterações: "Art. 208. I - educação básica obrigatória e gratuita dos quatro (quatro) aos 17 (dezessete) anos de idade".

Em 2014, o Ministério da Educação (MEC) oficializou o novo Plano Nacional de Educação (PNE), que determina diretrizes, metas e estratégias para a política educacional brasileira nos próximos dez anos. E estabeleceu como meta $\mathrm{n}^{\circ} 1$ : universalizar, até 2016, a educação infantil na pré-escola para as crianças de 4 (quatro) a 5 (cinco) anos de idade e ampliar a oferta de educação infantil em creches, de forma a atender, no mínimo, $50 \%$ (cinquenta por cento) das crianças de até 3 (três) anos até o final da vigência deste PNE e, na meta 2: universalizar o ensino fundamental de 9 (nove) anos para toda a população de 6(seis) a 14 (quatorze) anos e garantir que pelo menos $95 \%$ (noventa e cinco por cento) dos alunos conclua essa etapa na idade recomendada, até o último ano de vigência deste PNE, outra vez assegurando o ingresso obrigatório da criança ainda na Primeira Infância no ensino fundamental.

2 E em 1998 foi homologado o Parecer do Conselho Nacional de Educação, que estabelecia as Diretrizes Curriculares para a Educação Infantil. 
Em 2014, a Rede Nacional Primeira Infância iniciou um forte movimento pela aprovação do Projeto de Lei $n^{\circ}$ 6.998/2013, de autoria do Deputado Osmar Terra e outros membros da Frente Parlamentar da Primeira Infância, que altera o art. $1^{\circ}$ e insere dispositivos sobre a Primeira Infância na Lei n ${ }^{\circ} 8.069$, de 13 de julho de 1990, que dispõe sobre o Estatuto da Criança e do Adolescente, sobre o Decreto Lei n 3.689, de 3 de outubro de 1941 - Código de Processo Penal; a Consolidação das Leis do Trabalho - CLT, aprovada pelo Decreto-Lei ${ }^{\circ}$ 5.452, de $1^{\circ}$ de maio de 1943; a Lei $n^{\circ} 11.770$, de 9 de setembro de 2008, que cria o Programa Empresa Cidadã, destinado à prorrogação da licença-maternidade mediante concessão de incentivo fiscal, e altera a Lei no 8.212, de 24 de julho de 1991 e a Lei ${ }^{\circ} 12.662$, de 5 de junho de 2012, que assegura validade nacional à Declaração de Nascido Vivo - DNV, regula sua expedição, altera a Lei no 6.015, de 31 de dezembro de 1973.

Em 2016, é sancionada a Lei n 13.257 , que criou o Marco Legal da Primeira Infância.

Em 2020, temos pela primeira vez na história uma proposta de plano orçamentário, que deixa absolutamente claro e inscrito o compromisso com a infância. A Comissão Mista de Planos, Orçamentos Públicos e Fiscalização do Congresso Nacional ofereceu um Parecer Preliminar ao Projeto de Lei do Plano Plurianual 2020-2023, destacando o Programa de Atenção Integral à Primeira Infância, apresentando meta ambiciosa, pois pretende ampliar o atendimento de crianças (da gestação até os 6 anos) dos atuais 357 mil beneficiários para 3 milhões até o final do ano de 2023.

Em que pesem todos os avanços, não se pode arrefecer a luta, para o atendimento educacional de aproximadamente vinte milhões de crianças de até seis anos, pois ainda somos uma sociedade profundamente desigual. Sem desmerecer todos os demais direitos sociais, inscritos na CF, como alimentação, moradia, transporte, saúde e assistência social, por exemplo, todos esses não se realizariam não fosse a educação, que cria as condições para que se possa usufruir plenamente de todos os direitos. Por tudo isto, insistimos na inclusão da educação entre os Direitos Fundamentais.

\section{O FUTURO EM 1000 DIAS}

Os primeiros anos, 1000 dias de vida de uma criança, são particularmente importantes. Os neurocientistas ressaltam que já durante a gestação há um movimento extraordinário de conexões neurais. Os mil dias são aqueles que vão da gestação humana, que dura cerca de 270 dias e somados aos dois primeiros anos de vida do bebê, cada ano com 365 dias, portanto, 730 
dias, constituem os primeiros 1000 dias de vida do bebê. Nesse período ocorrem trilhões de conexões no cérebro do bebê humano, atingindo o pico de sua atividade.

Os bebês aprendem nos primeiros anos como jamais aprenderão ao longo de toda a sua vida. Essa razão já seria suficiente para priorizar a Primeira Infância, se não tivéssemos outras tão importantes quanto esta.

$\mathrm{Na}$ fase de zero a dois anos, os estudiosos observaram um importantíssimo desenvolvimento cerebral. Cientistas informam que nos 1000 (mil) dias de vida o desenvolvimento cerebral é tão intenso que é possível estabelecer até 700 novas conexões neuronais por segundo, praticamente o dobro de sinapses executadas aos dez anos de idade, de acordo com estudos feitos pela Academia Nacional de Ciências dos Estados Unidos (2015).

O pediatra Jack P. Shonkoff ${ }^{3}$ (2016), do Centro de Desenvolvimento Infantil, da Universidade de Harvard, estudou um fenômeno chamado plasticidade cerebral, que ele descreveu como a capacidade do cérebro de ser flexível e adaptável e como ele pode reajustarse para assumir novos desafios. Jack Shonkoff (2016) afirma que o bebê ao nascer tem no cérebro todos esses neurônios, mas pouquíssimas conexões, pouquíssimos circuitos. Esses circuitos são rapidamente desenvolvidos nos primeiros anos de vida. "A plasticidade do cérebro está em níveis ótimos nos primeiros anos de vida da criança” (SHONKOFF, 2016, p. 98).

As causas para o desenvolvimento dessa plasticidade dependem da genética e do ambiente. Eles influenciam conjuntamente. Há uma série de predisposições e as experiências vividas por uma criança aproximam e potencializam essa extensão (SHONKOFF, 2016, p.97)

O cientista James Heckman, vencedor do Prêmio Nobel de Economia no ano 2000, realizou uma experiência de maior repercussão mundial para as políticas pela Primeira Infância. Foi o Projeto High Scope Perry Preschool que demonstrou com um estudo longitudinal, que acompanhou as crianças desde os 3 até os 41 anos de idade, que o investimento em programas de alta qualidade com respostas apropriadas às demandas das crianças resulta em um retorno de mais de 17 dólares por cada 1 dólar investido em programas sociais. Heckman expôs esse estudo em conferência realizada durante o I Seminário Internacional do Marco Legal da Primeira Infância, na Câmara dos Deputados, em 16 de abril de 2013.

James Heckman (2013), ao avaliar os dados sobre o desenvolvimento humano nos Estados Unidos, observou que a maneira mais eficiente de remediar problemas causados por ambientes familiares adversos é investir nas crianças em seus primeiros anos de vida. Para

\footnotetext{
${ }^{3}$ SHONKOFF, Jack. Professor de Pediatria na Faculdade de Medicina de Harvard e do Hospital Infantil de Boston Diretor do Centro da Criança em Desenvolvimento da Universidade de Harvard. Preside o Conselho Nacional Americano de Desenvolvimento Científico da Criança em Desenvolvimento.
} 
Heckman, os políticos devem ser sábios e levar em conta os resultados das ciências para fundamentá-las e devem ser bem planejadas para transferir capacidades. São incontestáveis os argumentos e evidências resultantes das pesquisas de diversas ciências que dão sustentação, bases fundamentais e diretrizes para a intervenção junto à primeira infância.

Ainda para o cientista, o investimento em políticas públicas para a primeira infância desde as idades mais precoces previne e melhora o estado de bem-estar e a abordagem das potencialidades do ser humano, tem impacto na redução das enfermidades crônicas das crianças pequenas, em suas habilidades sociais, cognitivas, emocionais e no rendimento e produtividade por toda sua vida (HECKMAN, 2013). ${ }^{4}$

Durante a conferência no I Seminário Internacional do Marco Legal da Primeira Infância, na Câmara dos Deputados, ele reiterou a relevância da participação dos pais no desenvolvimento pessoal das crianças, como de extrema importância dos mil primeiros dias de vida do ser humano, para desenvolver aprendizagens altamente significativas.

Em 21 de maio de 2019, James Heckman disse em uma entrevista à BBC que investir em educação para a primeira infância é a melhor 'estratégia anticrime'. A entrevista teve grande repercussão, uma vez que a BBC de Londres é uma emissora de TV e Rádio Pública, de muita credibilidade e alcance mundial. No Brasil, a entrevista ganhou repercussão no Jornal o Globo do dia 07/06/2019 e em outros órgãos de comunicação. O cientista destacou que o resultado anticrime é o principal do seu estudo. Para ele, o maior retorno para cada dólar investido em todos eles é a redução de crimes e a criação de um ambiente encorajador para as crianças.

\section{A DEMOCRACIA COMEÇA NO COLO DA MÃE}

Do momento em que uma nova vida é gerada até o momento em que a criança se incorpora ao convívio social, acontecem mudanças nas funções neurológicas, cognitivas e emocionais de relevância e intensidade impressionantes. É um período de crescimento intenso. Por isso, é fundamental entendermos como a biologia, a genética e a sociedade preparam essa nova vida, para viver e conviver no mundo.

Precisamos de um novo olhar sobre a primeira infância para entender, compreender, sentir e conviver com esse bebê humano. Certos cuidados com o novo ser são primordiais para o início da vida e determinantes do jeito dele ser e de existir no mundo.

\footnotetext{
${ }^{4}$ James Heckman em Conferência realizada durante o I Seminário Internacional do Marco Legal da Primeira Infância, na Câmara dos Deputados, em 16 de abril de 2013.
} 
Para o professor e filósofo Zejko Loparic (2020), um dos maiores estudiosos da obra de Donald Wood Winnicott ${ }^{5}$ (1896 a1971), o bebê humano nasce inacabado e precisa ser cuidado para integrar-se, temporalizar-se e personificar-se. Precisa sentir-se uno; aprender a mamar, falar e ter a ilusão de criação do seio da mãe; descobrir que ele existe independente da mãe; aprender a andar e a se relacionar com os outros, socializando-se, e ainda, precisa singularizarse. Por isto, o olho no olho; o abraço; o carinho e a conversa dos pais com o bebê, todas estas são atitudes simples que fortalecem todas as estruturas neurais da criança (LOPARIC, 2020).

Para o pediatra e psicanalista inglês Donald Winnicott $(1975$, p.96) tudo que uma criança precisa no início da vida é de uma "mãe suficientemente boa". E é nesse esforço de entender a psicologia do bebê, que Winnicott descobriu que o adoecimento do bebê era um fenômeno relacional, estava na relação mãe - bebê. Para ele, essas patologias são decorrentes das "falhas ambientais". Por exemplo, a mãe que não olha para o seu bebê ou que amamenta o bebê olhando para a televisão.

Para Winnicott (1975, p.96.), "as relações sociais começam no colo da mãe”. Essa relação mãe-bebê, se não for saudável, ou seja, se a mãe não for suficientemente boa, teremos crianças submissas que acatam os comandos da mãe, que não exercitam a sua criatividade, ou crianças que abstraem completamente o ambiente externo, se voltando para si, passando a se relacionar apenas com as suas fantasias interiores, podendo psicotizar.

Para Zeljko Loparic (2020), há casos de falhas ambientes muito mais graves que pode ter como consequência diferentes quadros psicopatológicos, dentre estes a psicose ${ }^{6}$. Ao falar de ambiente, nesta teoria, estaremos incluindo tanto o ambiente físico quanto os aspectos emocionais necessários ao desenvolvimento do bebê, representados por uma "mãe suficientemente boa" ou pessoa substituta, isto é, o começo da formação das relações pessoais.

O pediatra inglês buscava entender o adoecimento de bebês nos primeiros dias de vida: aquele bebê que não conseguia dormir; o bebê que ficava nervoso; que apresentava eczemas na pele; que chorava demais. E assim, começou a se dar conta de que a etiologia desses distúrbios pediátricos; distúrbios psicológicos; das patologias do bebê eram resultantes das relações entre bebês e suas mães. Mãe aqui, entendida como uma pessoa humana, não uma pessoa humana como objeto, segundo a psicanálise, mas a mãe/colo (LOPARIC, 2020).

\footnotetext{
${ }^{5}$ Donald Woods Winnicott foi um pediatra e psicanalista inglês. Para Winnicott, cada ser humano traz um potencial inato para amadurecer, para se integrar; porém, o fato de essa tendência ser inata não garante que ela vá ocorrer. Isto dependerá de um ambiente facilitador que forneça cuidados e esse ambiente é representado pela "mãe". Não necessariamente a própria mãe do bebê, mas aquela que efetua uma adaptação ativa às necessidades do bebê.

${ }^{6}$ Donald W. Winnicott, O brincar e a Realidade, 1975, P.96.
} 
O filósofo Luiz Felipe Pondé (2020) pergunta a Loparic ${ }^{7}$ : O que Winnicott ensina de novo em relação à tradição freudiana? E Loparic respondeu "Winnicott concebia que as relações sociais começam no colo da mãe".

No começo tudo que o bebê precisa é do colo da mãe (WINNICOTT, 1975). Ao falar de ambiente, nesta teoria, estaremos incluindo tanto o ambiente físico quanto os aspectos emocionais necessários ao desenvolvimento do bebê, representados por uma "mãe suficientemente boa". Depois dessa fase de integração, precisamos da mãe que cumpre a função de personificação, trocando a frauda, expondo o bebê à luz, fazendo-lhe experimentar a audição das vozes das pessoas, tocando em cada uma das partes do corpo da criança, permitindo a formação pelo bebê da sua imagem corporal etc. Todas essas experiências sensoriais são importantes para formação da personificação.

Também é fundamental que a mãe apresente os objetos ao bebê, sendo o seio o primeiro deles e objeto de satisfação que permite ao bebê o exercício da onipotência da ilusão de tê-lo criado. E, ainda, é o começo da formação das relações pessoais. Também chama-nos a atenção para uma aprendizagem muito necessária que o bebê realiza na relação com a mãe para as relações futuras, lidando com a ambivalência: amor e ódio (WINICOTT, 1975).

Para Loparic (2020), maturidade é sinônimo de saúde; uma pessoa saudável é matura, significa capacidade de tolerar o amor e ódio com outra pessoa ou com outro grupo social e ressalta que, embora Winnicott tenha tomado de Freud a abordagem das relações humanas, compreendia que o bebê está no colo da mãe para existir, não por uma questão sexual; ele precisa do ambiente para existir; para existir como uma unidade pessoal; como alguém que precisa se relacionar com o ambiente e com o mundo a sua volta; entrar no mundo familiar, escolar, na sociedade.

Desses cuidados iniciais dos bebês dependem as suas capacidades de se concentrarem e deslocarem a sua atenção, de administrarem os sentimentos, controlarem os impulsos, seguirem regras e orientações, de se adaptarem a uma série de demandas, mas principalmente confiarem no ambiente, em si, no outro, no ambiente.

Então, a democracia se assenta nas capacidades adquiridas no colo da mãe e na relação com a família. A democracia, no fundo, depende das aquisições do bebê humano no colo da mãe, na família e na escola.

\footnotetext{
${ }^{7}$ No canal Democracia na Teia, o filósofo Felipe Pondé (2020) entrevistou o filósofo Zeljko Loparic que é professor da Unicampi e destacado estudioso da obra de Donald Winnicott no Brasil, tendo relevantes contribuições em outros países, especialmente na China.
} 
Perguntado por Felipe Pondé se democracia para o winnicottiano é uma questão de saúde psíquica, Loparic (2020) responde que sim. Numa situação de conflito social, uma pessoa saudável vai se colocar de um lado ou do outro, sem que isso signifique a exclusão do outro lado; a satanização; o aniquilamento do outro ou do grupo social. Portanto, para os teóricos winnicotianos, "a democracia começa no colo da mãe".

\section{CONCLUSÕES}

O país começa a se beneficiar de conhecimentos científicos e a colher os seus frutos, com a criação de leis e aplicações nas políticas pela primeira infância. As recentes descobertas científicas sobre o desenvolvimento intenso do cérebro humano na Primeira Infância, associadas aos argumentos econômicos e sociais, tornam incontestáveis à necessidade de alçar a educação infantil como um direito fundamental, comparando-o ao direito à vida. Deve-se destacar que todas as razões sobre as quais discorremos guardam profunda relação com a necessidade de superação da desigualdade social, ou seja, promover a igualdade ao nascer.

Para além da diferença de classe, a raiz da desigualdade social se realiza na diferença de cuidados e educação ao nascer. As razões para investirmos nas políticas pela Primeira Infância são muitas e algumas mais disseminadas, como: as experiências nesta fase da vida são persistentes e duradouras, com impacto para toda a vida; há elevada capacidade e plasticidade do cérebro em formação das funções cognitivas e demais funções; há nessa fase ausência de conflitos entre meritocracia e igualdade de oportunidades, o que nivela os pontos de partida e dá igualdade de oportunidades; todas as crianças são similarmente talentosas na Primeira Infância; os investimentos iniciais são duradouros, influenciando o ciclo de vida total.

É preciso um esforço gigantesco para unir todas as forças dos governos, das instituições educacionais, pais e professores; especialistas da área da saúde; da assistência social e da psicologia; profissionais de arte, da cultura e esporte, com o objetivo de prevenir e buscar solução para a banalização da vida, dedicando tempo, energia, conhecimento e muito amor pela Primeira Infância.

\section{REFERÊNCIAS}

ACADEMIA NACIONAL DE CIÊNCIAS DOS ESTADOS UNIDOS. In: Bibiano, Bianca. Por que investir na Primeira Infância pode mudar o Brasil. Revista Veja, 2015. Disponível em: http://veja.abril.com.br/noticia/educacao/por-que-investir-na-primeira-infancia-pode-mudar-obrasil. Acesso em: mar. de 2010 
AZEVEDO, Fernando de et al. Manifesto dos Pioneiros da Educação Nova (1932) e dos Educadores (1959). Fundação Joaquim Nabuco, Recife: Editora Massangana, 2010.

BERNARDI, Iara; ROCHA, Maria José. Educação Infantil: um direito fundamental. In: Marco Legal da Primeira Infância. Centro de Estudos e Debates Estratégicos - Cedes. Câmara dos Deputados, Brasília, 2016.

BRASIL. PARECER CNE/CEB 22/1998 - Homologado em 22/3/1999, publicado no Diário Oficial da União de 23/3/1999, Seção 1, p. 8.

Resolução CNE/CEB 1/1999, publicada no Diário Oficial da União de 13/4/1999, Seção 1, p. 18.

SANTOS, Daniel D.; PORTO, Juliana A.; LERNER, Rogério. O Impacto do Desenvolvimento na Primeira Infância sobre a Aprendizagem. 2. ed. São Paulo: Fundação Maria Cecília Souto Vidigal, 2015.

WINNICOTT, Donald Woods. O Brincar e a Realidade. Imago Editora: Rio de Janeiro, 1975. 


\title{
O EXERCÍCIO DA CIDADANIA NA SOCIEDADE BRASILEIRA: REFLEXÃO A PARTIR DAS OCUPAÇÕES DAS ESCOLAS ESTADUAIS PAULISTAS EM 2015
}

\author{
Roseli Trevisan Marques de Souza ${ }^{1}$
}

\section{RESUMO}

O escrito intenta refletir sobre o exercício da cidadania na sociedade brasileira a partir de alguns fatos observados antes e durante as ocupações das Escolas Estaduais Paulistas em 2015. Cabe destacar que foi proposta a reorganização das unidades do Estado Paulista e no discurso governamental veiculado ressaltava que essa política pública traria benefícios aos estudantes da Educação Básica. Mas, quais? Essa questão permeou o pensamento dos jovens estudantes, movendo-os a uma reação de repúdio, condizente com a ideia de exercício da cidadania e pertinente às sociedades que têm como regime a democracia.

Palavras-chave: Democracia. Reorganização. Ocupações. Estudantes. Educação Básica.

\section{INTRODUÇÃO}

A sociedade contemporânea se demonstra pautada em um condensado de ideias que auxiliaram na formação humana e das sociedades. Um dos conceitos que permeia a realidade social há alguns séculos é o de democracia, o qual tem vínculo estreito com os termos cidadão e participação coletiva, que nada mais é do que o exercício da cidadania. Ocorre que, desde a era clássica, o termo cidadania é um conceito abstrato, pois sabe-se que nem todos podiam exercer um papel social de forma igualitária. Sabe-se também que nem todos eram beneficiados nas decisões desse grupo político, ou seja, havia uma divisão social. Independentemente dessa realidade, os representantes dessas sociedades debatiam e deliberavam.

Ainda hoje a ideia de cidadania ativa e de ser um cidadão participativo é um objetivo dos integrantes de muitas sociedades. No entanto, a aplicação do conceito de democracia também permanece como um grande desafio a ser transposto, pois há, como antes houve, membros excluídos das decisões do e para o todo e na atualidade essa exclusão se ampliou, principalmente nos países periféricos. O excluído é cidadão?

Fábio Konder Comparato, no título Educação, Estado e Poder (1987, p.30) considera que o poder pode ser caracterizado como um valor social supremo exercido pelo Estado.

\footnotetext{
${ }^{1}$ Doutora em Educação pela Universidade de São Paulo (USP). E-mail: rtms1962@gmail.com
} 
Segundo ele, este é o "grande organismo de poder político" (Ibidem, p.34), opondo-se ao poder pessoal, que envolve a ideia de exercício da cidadania.

Para Konder (1987), a cidadania vai além de ser um membro de uma dada sociedade com direitos a serem garantidos e deveres a serem executados. Implica em ter-se uma nação regida por uma Constituição aprovada no legislativo, mas também na participação, ou seja, na decisão e no acompanhamento conjunto dos processos de desenvolvimento; avaliando o processo; pensando nas mudanças, caso o andamento não esteja de acordo com o que se esperava para o coletivo.

É fato que somos parte de uma nação e por isso, já somos cidadãos, mas a partir da descrição de Konder, ser parte, de fato, está condicionado a uma postura de envolvimento. Para o autor, enfim, nós nos tornamos cidadãos se estivermos inseridos no contexto e interagindo com ele. Desta forma, numa sociedade como a brasileira, marcada pelo autoritarismo inerente ao patriarcado, é preciso aprender constantemente sobre tomada de decisão coletiva. Tal aprendizagem se dará em espaços de diálogo e a escola certamente é um deles.

Outro aspecto, no que consiste a ser visto como cidadão, está na obra $A$ Construção Social da Subcidadania: para uma sociologia política da modernidade periférica, de Jessé Souza (2012), em que afirma que a desigualdade social implica no ostracismo ${ }^{2}$ participativo. Ele diz que essa condição social se dá pela "hierarquia valorativa" existente nas sociedades de extrema desigualdade social originada do sistema econômico reinante, definindo "quem é ou não é "gente” (...) e por consequência quem é ou não cidadão." (2012, p. 181). Diz também que estamos em uma sociedade democrática aberta (2012, p. 180), ancorada na lógica da dominação simbólica que também separa/divide e exclui, quando desvaloriza as culturas populares, deflagrando a ideia de "subcultura" e consequentemente de "subpolítica". Ou seja, há uma divisão social que prioriza os valores e a participação de apenas uma parcela da sociedade.

Um dos aspectos que possibilitam essa divisão social é a educação escolar como direito, mas, é claro, uma educação para a participação. A educação formal é um direito à população e um dever do Estado. Essa fala está posta na Constituição Federal de 1988 e reafirmada na Lei de Diretrizes e Bases da Educação, nº 9394/96. Trata de uma educação pública e gratuita, garantindo também o acesso dos estudantes às unidades escolares de todas as classes sociais, da permanência deles, bem como da qualidade da aprendizagem desses alunos. Pelo menos na lei, são alvos a serem atingidos. Mas, na verdade, quando se verifica a prática quanto aos amplos direitos educacionais, deparamo-nos com as políticas públicas educacionais que são aplicadas

\footnotetext{
${ }^{2}$ Termo utilizado nesse artigo no sentido de participação política. Segundo o dicionário Houaiss, na antiga Grécia, o termo significava desterro político e atualmente envolve também exclusão política.
} 
sem o conhecimento da população. Em quais aspectos as lideranças governamentais contribuem para que haja um cenário social participativo?

Segundo Paes-Sousa; Hellmann (2013) ${ }^{3}$, as políticas públicas no Brasil não costumam ser elaboradas com a contribuição direta dos que por elas são afetados. Um movimento no sentido da participação coletiva requereria a descentralização das decisões, implicando na inserção dos mais pobres nos debates políticos. Se compreendermos desta forma, a decisão de reorganizar as escolas foi uma decisão arbitrária dos governantes de São Paulo e os jovens, ao refutá-la, exerceram seu direito posto em Constituição, de serem contrários à determinação legal e de se afirmarem nesse processo como cidadãos participativos.

\section{A REORGANIZAÇÃO DAS ESCOLAS}

Destaca-se que o procedimento da reorganização englobava duas ações iniciais: fechar 94 prédios escolares e remanejar um grande número de discentes e docentes. Tais decisões levaram os jovens à ocupação paulatina de 200 escolas no Estado de São Paulo. O Governo estadual promulgou o Decreto $\mathrm{n}^{\circ}$ 61.672, de 30-11-2015 e, por resistência dos jovens, em 0412-2015, foi publicado o Decreto $\mathrm{n}^{\mathrm{o}}$ 61.692, revogando o anterior. Isto é, não houve reorganização devido à ação cidadã dos discentes.

Antes mesmo da publicação no Diário Oficial do Estado da decisão governamental de reorganizar, os discentes se organizaram para compreender o que estava acontecendo e, após a interpretação dos fatos e aos debates sobre como reagir ao pleito, iniciaram as ocupações. No que se refere à ideia de reorganização, esse termo compõe o léxico das políticas públicas há algumas décadas. Inclusive em 1995, em São Paulo, houve uma similar, que vingou, não sofrendo a resistência que houve em 2015.

Ressalta-se que desde 1995 muitas escolas da Educação Básica, por todos os estados do Brasil, têm sido fechadas. Segundo Eliza Botolozzi Ferreira (2009, p.255) ${ }^{4}$, "as reformas empreendidas na década de 1990 tentaram redimensionar o Estado, revesti-lo de novas competências e funções, não mais promotor direto do crescimento econômico, mas somente catalizador e facilitador".

\footnotetext{
${ }^{3}$ PAES-SOUSA, R.; HELLMANN, A. Monitoring and evaluation systems: recent advances in Brazil's federal public administration. In: VAITSMAN, J.; RIBEIRO, J.M.; LOBATO, L. (Orgs.). Policy Analysis in Brazil. Bristol: Polity Press, 2013.

${ }^{4}$ FERREIRA, Eliza B. A contrarreforma do Ensino Médio no contexto da nova ordem e progresso. A produção deste texto está inserida nos estudos desenvolvidos na pesquisa "Programa ensino médio inovador: condições de trabalho e formação docente". Disponível em: http://www.scielo.br/pdf/es/v38n139/1678-4626-es38-139-00293.pdf acesso em: 24 mar.2019.
} 
Mas, independentemente desse cenário, uma nova forma de resistência dos alunos da educação básica foi iniciada a partir de 2012, em Goiás: uma escola seria fechada e os estudantes a ocuparam, revertendo o pleito. Em 2015, o mesmo movimento aconteceu, foi maior e ganhou espaço nas redes sociais, na mídia formal e informal. Os estudantes da educação básica, nesse segundo ato, contaram com o apoio de parcela da sociedade para reverter o autoritarismo governamental.

Foi um período curto de manifestações, mas crucial, pois o ano letivo estava por finalizar. Ressalta-se ainda que esse momento poderia ter passado despercebido se pesquisadores, em geral do campo da educação, não registrassem o histórico (SOUZA; CATANI, 2019). Os estudos têm trazido luz aos discentes como atores políticos e à realidade educacional que os envolvia. Compreendeu-se que a sociedade brasileira estava diante de cidadãos que cumpriam seu papel social, independente do poder exercido pelo estado sobre o todo. Trata-se de um fenômeno social, vinculado a um novo despertar do estudante brasileiro para a vivência da democracia, descontruindo a ideia de que o poder deve permanecer nas mãos de alguns privilegiados, esses sim poderão ter voz no todo. Jessé Souza (2012, p. 64) diz que:

Nas sociedades periféricas modernizadas de fora para dentro, como a brasileira, "gente" vai ser o "europeu". Embora em São Paulo, cidade analisada por Florestan Fernandes em seu estudo, o referente empírico da "europeidade" seja efetivamente em "europeu", no caso o imigrante italiano.

Diante desse discurso, observa-se que o preconceito grita alto em São Paulo e quem não é parte plena dessa elite jamais ganhará status de cidadão. No máximo, terá que batalhar muito para sobreviver, pois escola de qualidade nesse contexto é apenas um luxo.

\section{O PODER HEGEMÔNICO}

De Maquiavel, passando por Hobbes até a contemporaneidade, muitos pensadores têm relatado, sob várias perspectivas, o papel que este organismo estatal desempenha na sociedade. Em Sobre o Estado: cursos no Collège de France 1989-92 (2014, p.30), Pierre Bourdieu referese ao Estado como "campo de poder". Diz também que o Estado Moderno tem o poder simbólico como dimensão que o legitima.

Nos últimos 30 anos, comumente, esse exercício da cidadania por parte dos estudantes da educação básica ficou relegado, principalmente pelos membros dessa faixa etária na sociedade brasileira, pois a maioria dos jovens transferia esse papel para aqueles que estão nos congressos/assembleias. Van Dijk, em Discurso e Poder (2004), destaca que a linguagem da 
elite simbólica contribui para uma redução participativa, e que o discurso dos integrantes das arenas políticas precisa ser alvo de estudos, caso se objetive participação ampla nas decisões de dada sociedade. No segundo capítulo do livro desse autor, ele analisa como é exercido o poder social, apresenta as principais características dessa ação e, finalmente demonstra como a classe hegemônica produz e veicula falas, cuja intenção é o controle cognitivo e ideológico da população de dominados.

Segundo Gramsci (1962), a sociedade civil se constitui em organismo de resistência ao estado, mas no Brasil, a sociedade civil com representatividade é aquela que também participa das fatias do bolo da classe dominante. A partir de 1990, sindicatos e representantes de movimentos sociais, por exemplo, costumam ser excluídos das decisões que envolvem o todo, comprometendo a participação de alguns membros da sociedade civil e ampliando a ideia de domínio de uma classe sobre outra.

Os participantes das ocupações, naquele momento, reconheceram a necessidade da existência de uma nova concepção de estado, de educação, de política e de cidadania similar ao descrito na Constituição Federal de 1988. Para eles, o autoritarismo do governo era um aspecto que distorcia o papel estatal posto na Carta Magna e era necessário esse resgate por meio de um movimento estudantil. Boaventura de Souza Santos (2002, p. 26) diz que os ativistas e líderes de movimentos e organizações populares aprendem na luta contra os poderes hegemônicos o saber prático que faz mover o mundo, e mais do que qualquer outro, dá sentido ao mundo.

\section{ESTADO X SOCIEDADE}

Os movimentos estudantis não são novidades no mundo e no Brasil. Sabe-se, também, que as tensões entre estado e sociedade são recorrentemente a mola mestra dos movimentos sociais. Destacamos os movimentos da década de 1960. Entre 1964 e 1965 tem-se as manifestações no campus da Universidade da Califórnia em Berkeley. Nesse período, outros movimentos ocorreram ainda nos Estados Unidos da América, bem como na Europa e no Brasil a partir de 1968.

Na década de 1990, outras manifestações jovens. Ressaltamos os eventos em Seattle em 1999. No século XXI, em 2011, no Ocuppy Wall Street, jovens indignados pela falta de ética, de moral, de valores e de justiça social se manifestaram (GOHN, 1997) ${ }^{5}$. Em 2013, o 
Movimento do Passe Livre. No mesmo ano, na USP, houve também ocupação da reitoria para definir linha de trabalho no Campus.

Boaventura de Souza Santos, no livro Democratizar a Democracia: os caminhos da democracia participativa (2002), afirma que há olhares cuidadosos dos pesquisadores para a globalização, para a democratização e para o neoliberalismo. Estudam-se as formas que os ativistas e outros manifestantes refutam as práticas regulatórias dadas por políticas públicas. $\mathrm{Na}$ obra organizada por ele, há a preocupação em atribuir sentido à expressão "democracia participativa", tendo em vista que guarda estreita relação com o tipo de governo e de sociedade vigente em um país.

Geralmente, os movimentos decorrem de uma realidade mundial, na qual o Estado vem redefinindo seu papel, se propondo a minimizar os deveres a serem cumpridos com o todo social, com base nos pressupostos neoliberais. No Brasil, a partir de 1995, reformas educacionais foram empreendidas e escolas da educação básica foram fechadas. As práticas de descentralização administrativa foram aplicadas com a finalidade de privatização da gestão pública. Ferreira (Ibidem, p. 256) diz: “a reforma buscou consolidar a figura de um estado gerencial, com capacidade de regulação social mediante a transferência a outros setores/instituições da responsabilidade de prestação dos serviços sociais".

À administração gerencialista, agrega-se um Estado que usa instrumentos de violência para garantir o poder político e econômico nas mãos de poucos. O Estado existe, enfim, como instituição a serviço da classe hegemônica, inibindo a resistência de outros segmentos da sociedade com políticas públicas autoritárias e excludentes e com ações de contenção social.

Continuando a análise sobre o gerenciamento do Estado com base nos princípios neoliberais, no artigo intitulado Limitações da Participação e Gestão Democrática na Rede Estadual paulista, publicado na "Revista de Ciências da Educação", vol. 37, out-dez de 2016 (CEDES, $n^{\circ}$ 137. p. 1153), nota-se que essa medida governamental, na verdade, tinha como referência o mesmo gerenciamento aplicado em 1995. Segundo Dalila Oliveira (2009, p.25), no capítulo Política educativa, crise da escola e a promoção da justiça social, do livro "Crise da Escola e Políticas Educativas", a inabilidade estatal em atuar em face dos pressupostos que regulamentam a educação fundamental no Brasil é um fato recorrente em países pobres e populosos em todo o mundo. Trata-se de uma crise ainda carente de administração no século XXI, e isso ocorre, principalmente, devido à política neoliberal que tem postulado antagônica ao descrito no artigo 205 da Carta Magna e da LDB 9.394/96. 
Teóricos como Dalila (2009), Frigotto (2009) e Mészáros (2008) afirmam que o posicionamento estatal a favor dos pressupostos neoliberais fere o direito à educação, a formação para a cidadania e à qualidade de ensino. Em 2017, o Secretário da Educação de São Paulo, da época, escreveu um livro intitulado: A Educação Básica pública tem solução? (VOORWARD, 2017). Nele, o autor justificou que a reorganização tem como motivação "a diminuição no número de matrículas na Rede Pública da Educação Básica do Estado de São Paulo e a mobilidade populacional nos últimos anos" (VOORWARD, 2017, p. 108). Ademais, diz ter considerado mais algumas premissas: "modelos de escola; tamanho de escola; estrutura física; e logística" (Ibidem, p. 108). Ou seja, na ação, compreenderam a necessidade de realocar alunos, funcionários e professores das escolas que seriam fechadas em outros prédios, reduzindo assim o número de unidades escolares sob a responsabilidade do Estado.

Quando utilizada a expressão "modelos de escola" (grifo nosso) pensava-se na ampliação do ensino médio diurno com ensino integral, que é uma das metas do Plano Nacional de Educação (MEC, 2014-2024), mas e o que aconteceria com os estudantes do ensino médio noturno? O que se fariam com a evasão crescente dos estudantes desse segmento? As respostas para essas questões, na atualidade, são claras. A ideia era simplesmente reorganizar, adequando utilização dos recursos públicos (SOUZA; CATANI, 2019). Na leitura do livro de Voorward, não se observa a busca por compreensão dos reais motivos para a redução das matrículas, bem como uma reflexão sobre os desdobramentos dessa política, em especial, o aumento da evasão escolar.

Independentemente dessa realidade de exclusão política, uma parcela de jovens de alguns países da América Latina tem atuado contra os desmandos governamentais. No que se refere à educação, temos como exemplo, as ocupações das escolas no Chile em 2006, depois na Argentina em 2011; em seguida, no Brasil, em 2012, 2013, 2015 e em 2016, quando ocorreram ocupações nas escolas do Sul, do Centro-Oeste e do Nordeste Brasileiro, colocando em xeque a pretensa racionalidade política e a doutrina do Estado neoliberal. A prática desenvolvida tem sido destacada ao longo do texto, uma prática cidadã. Mas, quem são esses jovens e de onde nasceu essa disposição à participação tem sido nosso questionamento atual para futura publicação.

\section{A VEICULAÇÃO E O PLANEJAMENTO DA REORGANIZAÇÃO}

Retomando ao tema deste capítulo, o que denota o autoritarismo dessa política pública? Alguns aspectos já foram ditos, um deles é a necessidade da redução de gastos da máquina 
pública em detrimento da qualidade na aprendizagem. Gostaríamos de destacar, ainda, um caminho trilhado pela SEE/SP e os objetivos específicos para impor a política governamental.

Em São Paulo, foi veiculado um paper pela Secretaria da Educação de São Paulo (SEE/SP), apontando o decréscimo demográfico como motivo para o fechamento de escolas. Santos e Vieira (2017) dizem:

\begin{abstract}
Assumindo que o índice de envelhecimento teria pouca variação entre 2010 e 2016, observamos que 15, das 25 escolas da capital a serem fechadas, estão em áreas onde atualmente consta um baixo índice de envelhecimento populacional. No entanto, onze escolas estão em áreas em que nos próximos quinze anos há tendência de envelhecimento - isto é, a diminuição do número de crianças e o aumento do número de pessoas com mais de 60 anos. Apenas cinco escolas, situadas em regiões periféricas (quatro no extremo leste - Guaianases, Lajeado e São Miguel; e uma na zona sul - Capão Redondo) estão em áreas em que deverá persistir uma baixa razão de idosos (2017, p.13).
\end{abstract}

Ademais, no artigo intitulado A geografia da reorganização escolar: uma análise espacial a partir da cidade de São Paulo, há um mapa da reorganização das escolas elaborado por Eduardo Donizete Girotto, Felipe Garcia Passos, Larissa Campos e João Oliveira (2017), e nele se encontram outros motivos para reorganizar as escolas, como por exemplo, atendimento ao mercado imobiliário e a construção de linhas do Metrô na cidade de São Paulo.

Segundo se observa no texto de Emir Sader (2008, p.15), que prefacia o livro de Mészáros (2008), A educação para além do capital, a decisão de fechar escolas tem origem mercadológica e coloca a educação básica pública "como instrumento de poder capitalista" (2008, p.16). Ele completa: "No reino do capital, a educação é, ela mesma, uma mercadoria. Daí a crise do sistema público de ensino, pressionado pelas demandas do capital e pelo esmagamento dos cortes de recursos dos orçamentos públicos". Ou seja, a veiculação foi mínima e o planejamento estava pautado em captação de recursos para o Estado, disponibilizando terrenos das escolas centralizadas para a inciativa privada, aglomerando os alunos das unidades nas regiões periféricas, deflagrando a existência de espaços de exclusão e validando a condição de uma sociedade desigual.

\title{
A DESIGUALDADE SOCIAL
}

A desigualdade social é o resultado da grande exploração do trabalho, ação própria do sistema capitalista. Nessa concepção de mundo, como destaca Jessé Souza (2012, p. 181), fica evidente quem é ou não participe da dimensão sociopolítica, apenas uma elite. A grande parcela da sociedade está excluída das decisões, por isso, nesse modelo de sociedade não há, de fato, preocupação com formação para o exercício da cidadania. 
Para Boaventura de Souza Santos (2002, p.22), no plano organizacional, se a sociedade vive uma realidade contrária ao conceito de democracia, a proletarização social se instaura e poderá ser alterada quando a população excluída resistir à condição desigual e atuar contra hegemonicamente, inibindo a lógica do capitalismo global, ou seja, quando os membros dominados buscarem conjuntamente a emancipação social. Segundo o mesmo autor, a resistência comumente é protagonizada por ativistas e líderes de movimentos e organizações populares que confrontam as forças de poder, dando sentido às relações humanas no mundo. Essas articulações são aprendidas no cotidiano de uma formação cidadã e representam uma das formas de conquista da democracia participativa.

$\mathrm{Na}$ proposta de reorganização escolar em 2015, por exemplo, seria remanejado um número significativo de discentes e docentes. Os jovens não suportaram essa ideia e resistiram à decisão. Eles estavam sendo impulsionados a um novo convívio escolar, deixando para trás, subitamente, as amizades travadas ao longo da escolaridade, o espaço escolar e os professores que conheciam. O aluno seria alocado em uma escola vizinha. Mas as possibilidades de mudança, fossem quais fossem, os expunha à violência simbólica e deixava evidente a condição de dominados no cenário social. Os estudantes submetidos à realidade descrita apresentavam sinais de insatisfação, indignação diante da forma de como se deu o processo de reorganização, por isso ocuparam as escolas públicas do estado de São Paulo. Nota-se, nesse cenário, que a voz deles não importava à Secretaria Estadual de Educação/SP.

Conforme evidenciado, nota-se que a educação brasileira convive com leis pautadas no ideário democrático, porém, na prática, vivenciam políticas governamentais próprias do neoliberalismo que deixam evidentes a divisão social e a pouca responsabilidade do Estado com quem está no lado frágil dessa sociedade. Diante disso, infere-se que a ação governamental tinha como foco privilegiar os já privilegiados, foi simbolicamente violenta, pouco preocupada com a construção de uma sociedade verdadeiramente democrático-participativa. Com efeito, a população precisa estar em constante alerta para fazer valer seus direitos e foi justamente isso que fizeram os jovens que ocuparam as escolas de São Paulo em 2015.

Para Boaventura de Souza Santos (2002, p. 27), "a democracia participativa confronta privilegiadamente a dominação, o patriarcado e a diferenciação identitária desigual". Diz também que a ação de resistência confronta todas as formas de poder, resulta na emancipação social e conseguintemente no aprendizado da cidadania e no ato de se tornar cidadão. Apesar dessa realidade, observa-se que ainda existe uma grande barreira a ser derrubada para que os mais pobres possam, de fato, participar das decisões. São avanços e retrocessos que fazem da jornada democrática ser exaustiva e contar com poucos ajudadores. Estratégias dos governos 
autoritários contra a educação são recorrentemente utilizadas no intuito de que a sociedade não conte com a participação efetiva do todo.

\section{CONSIDERAÇÕES FINAIS}

Registrou-se nesse texto, portanto, pouca ou nenhuma sensibilidade do poder público com as necessidades reais de educação da população, resultado dessa insensibilidade se expressa pela realidade da evasão escolar/abandono e pelas escolas cada dia mais deterioradas e com um quadro insuficiente de professores e funcionários. Destaca-se nesse sentido, a ocorrência da lógica internalizada da política econômica neoliberal que está desconstruindo o conceito de educação escolarizada e que aposta no aumento da desigualdade social para se manter firme. Desta forma, a omissão do Estado em investir na melhoria da escola pública de educação básica, resulta no aumento da exclusão social.

Existe uma legislação que visa a garantir a educação formal. A Constituição Federal de 1988 é um repositório do direito alegadamente plurilateral, mas, na prática, nem todos são iguais perante a lei. Alguns têm mais privilégios que outros. Atuar contra hegemonicamente é a forma de garantir os direitos de todos. Nesse sentido, são os movimentos estudantis que tem feito esse papel, bem como o sindicato dos professores e os membros da academia diretamente vinculados à educação.

O que se tem, então, é um pacto entre o Estado e o Capital Financeiro com vistas ao controle da população e ao atendimento dos interesses de quem detém o capital, e nesse processo desqualificam e reprimem toda resistência social, fragilizando as ações desses grupos preocupados com esta realidade opressiva. $\mathrm{O}$ alvo mais atingido é a educação para o povo, pois sem essa educação a participação coletiva jamais se ampliará, ou seja, não teremos descentralização do poder.

No que concerne à Educação Básica pública do Estado de São Paulo, os líderes governamentais tem seguido uma linha condutora, culminando no esvaziamento escolar, no aumento da desigualdade social e na ampliação da exclusão social. Contra esse estado de coisas, em São Paulo, em 2015, alguns estudantes se manifestaram, mas, em 2020, não se observa uma atuação efetiva para inibir o avanço desse autoritarismo. Caberia compreender esse silêncio. Trata-se de um recuo aos ideais de cidadania e de democracia dos jovens ou de uma opressão/repressão velada por parte dos órgãos governamentais? Essa dúvida não será esclarecida, mas temos como fato, mediante ao observado nas ocupações e depois em outros eventos similares de jovens estudantes por todo o Brasil, que a formação cidadã está fragilizada 
em nosso país por interferência de um Estado que quer apenas dominar e não emancipar seu povo.

\section{REFERÊNCIAS}

BOURDIEU, P. Sobre o Estado: Cursos no Collège de France (1989-92). São Paulo: Companhia das Letras, 2012.

BRASIL. Constituição da República Federativa do Brasil: promulgada em 5 de outubro de 1988. Brasília, $1988 . \quad$ Disponível em: http://www.planalto.gov.br/ccivil_03/constituicao/constituicao.htm. Acesso em: 29 mar. 2020.

Lei $\mathbf{n}^{\circ}$ 13.415, de 2017. Altera as Leis $n^{\circ}$ 9.394, de 20 de dezembro de 1996, que estabelece as diretrizes e bases da educação nacional, e 11.494, de 20 de junho 2007, que regulamenta o Fundo de Manutenção e Desenvolvimento da Educação Básica e de Valorização dos Profissionais da Educação, a Consolidação das Leis do Trabalho - CLT, aprovada pelo Decreto-Lei $n^{\circ} 5.452$, de $1^{\circ}$ de maio de 1943, e o Decreto-Lei $n^{\circ} 236$, de 28 de fevereiro de 1967; revoga a Lei $\mathrm{n}^{\circ} 11.161$, de 5 de agosto de 2005; e institui a Política de Fomento à Implementação de Escolas de Ensino Médio em Tempo Integral. Disponível em: http://www.planalto.gov.br/ccivil_03/_Ato2015-2018/2017/Lei/L13415.htm. Acesso em: 25 de mar. 2020.

CASTELO BRANCO, G.; BAÊTA, L. F. N. (Orgs.) Michel Foucault: da arqueologia do saber à estética da existência. Rio de Janeiro: Nau, 1999.

FERREIRA E. B.; POCHMAN M. Escolarização de jovens e igualdade no exercício do direito à educação no Brasil: embates do início do Século XXI. Educação e Sociedade, Campinas, v. 37, n. 137, p. 1241-1270, jan./maio 2016.

FOUCAULT, M. Estratégia, poder-saber: ditos e escritos IV. Rio de Janeiro: Forense Universitária, 2006.

FOUCAULT, M. Aula de $1^{\circ}$ e de 8 de fevereiro de 1978. In: Segurança, Território, População: Curso dado no Collège de France (1977-1978). São Paulo: Martins Fontes, 2008a. p. 117-180. 293. Governamentalidade. In: Microfísica do Poder. Rio de Janeiro: Graal, 1979. p. 277 -

GIROTTO, E. D. A dimensão espacial da escola pública: leituras sobre a reorganização da rede estadual de São Paulo. Educação e Sociedade, Campinas, v. 37, n. 137, p. 1121-1141, out./dez. 2016.

GIROTTO, E. D et al. A geografia da reorganização escolar: uma análise espacial a partir da cidade de São Paulo. ETD - Educação Temática Digital, Campinas, v. 19, n. especial, p. 134158 , jan./mar. 2017. Disponível em: 
https://periodicos.sbu.unicamp.br/ojs/index.php/etd/article/view/8647805/15187. Acesso em: 25 nov. 2017.

GOHN, M. da G. Movimentos Sociais e educação. São Paulo: Cortez, 2013.

GOULART, D. C.; PINTO, J. M. R.; CAMARGO, R. B. de. Duas reorganizações (1995-2015): do esvaziamento da rede pública estadual paulista à ocupação das escolas. ETD - Educação Temática Digital, Campinas, v. 19, n. 1, p. 109-133, jan./mar. 2017. Disponível em: https://periodicos.sbu.unicamp.br/ojs/index.php/etd/article/view/8647797/15186. Acesso em: 20 mar. 2020.

GRABOIS, P. F. Resistência e revolução no pensamento de Michel Foucault: contracondutas, sublevações e lutas. Cadernos de Ética e Filosofia Política, v. 19, São Paulo. 2011. Disponível em: http://www.revistas.usp.br/cefp/article/view/55736.

GRAMSCI, A. Notas sobre Maquiavel, sobre política y sobre el Estado moderno. Buenos Aires: Lautaro, 1962.

LE GOFF, J. et.al. História e Memória. Campinas: Editora Unicamp, 1996.

LONGO, F. Demografia e Educação II: a reorganização escolar em São Paulo. São Paulo, 2017. Disponível em: https://demografiaunicamp.wordpress.com/2017/05/02/demografia-eeducacao-ii-a-reorganizacao-escolar-em-sao-paulo/. Acesso em: 14 jan. 2020.

MÉSZÁROS, I. A educação para além do capital. São Paulo: Boitempo, 2008.

NALINI, J. R. A reorganização escolar foi feita em gabinete, sem se abrir à discussão. Jornal El País, Brasil, 18 out. 2016. Disponível em: https://brasil.elpais.com/brasil/2016/09/22/politica/1474568354_586576.html. Acesso em: 18 nov. 2017.

NUNCA ME SONHARAM: documentário. Direção de Cacau Rhoden. 2017. Disponível em: https://www.youtube.com/watch?v=KB-GVV68U5s. Acesso em: 27 mar. 2020.

O MAL-EDUCADO. São Paulo, 2016. Disponível em: http://gremiolivre.wordpress.com. Acesso em: 14 jan. 2020.

PAPARELLI, R. Desgaste mental do professor da rede pública de ensino: trabalho sem sentido sob a política de regularização de fluxo escolar. 2009. 184 f. Tese (Doutorado) Instituto de Psicologia, Universidade de São Paulo, São Paulo, 2009.

SANTOS, B. S. Democratizar a democracia: os caminhos da democracia participativa. Porto: Afrontamento, 2003.

SANTOS, F. V. L. dos; VIEIRA, J. M. A reorganização escolar em São Paulo: uma reflexão sobre o uso de argumentos demográficos em políticas educacionais. [S.l.: s.n.]. Disponível em: http://abep.org.br/xxencontro/files/paper/175-321.pdf. Acesso em: 29 mar. 2020.

SÃO PAUlO. A Nova Estrutura Administrativa da Secretaria da Educação do Estado de São Paulo: Por uma Gestão de Resultado com Foco no Desempenho do Aluno. São Paulo: Secretaria da Educação, 2013.2 Disponível em: 
http://www.educacao.sp.gov.br/a2sitebox/arquivos/documentos/572.pdf. Acesso em: 20 jan. 2020.

Decreto n. ${ }^{\circ}$ 57.141, de 18 de julho de 2011: reorganiza a Secretaria da Educação e dá providências correlatas. São Paulo, 2011. Disponível em: https://www.al.sp.gov.br/repositorio/legislacao/decreto/2011/decreto-57141-18.07.2011.html. Acesso em: 20 jan. 2020.

Decreto n. ${ }^{\circ}$ 61.692, de 4 de dezembro de 2015. Revoga o Decreto n. ${ }^{\circ} 61.672$, de 30 de novembro de 2015. São Paulo, 2015a. Disponível em: http://www.al.sp.gov.br/repositorio/legislacao/decreto/2015/decreto-61692-04.12.2015.html. Acesso em: 18 nov. 2020.

SOUZA, R. T. M. de, \& CATANI, A. M. (2019). Movimento Estudantil: as ocupações nas escolas estaduais de São Paulo. Revista Inter Ação, 44(2), 475-498.

SOUZA, R. T. M. de. Escola pública do estado de São Paulo: inclusão ou exclusão social? In: MARIANO, Hélvio Alexandre. Infância e Seus Lugares. São Paulo: Paco Editorial, 2018.

TEDESCO, J. C. Qualidade na educação e políticas educacionais. Brasília, DF: Liber Livros, 2012.

VAN DIJK, T. A. Discurso e Poder. São Paulo: Contexto, 2008.

VOORWARD H. J. C. A educação Pública tem solução? São Paulo: editora Unesp, 2017. 


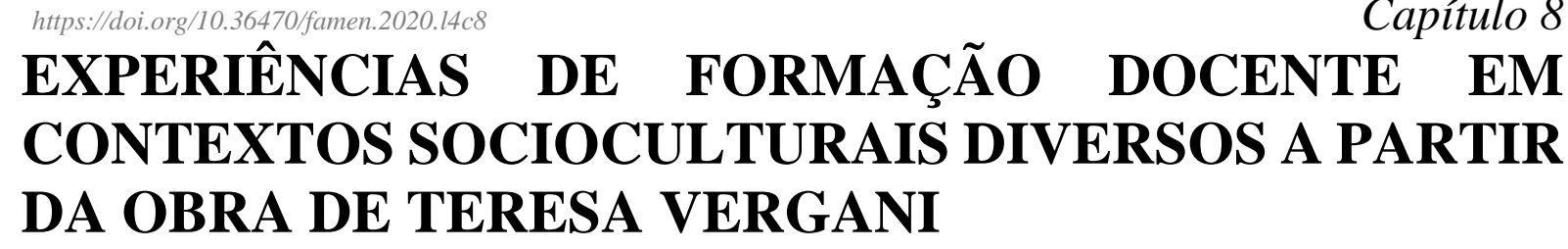

Capítulo 8

Louize Gabriela Silva de Souza ${ }^{1}$

\begin{abstract}
RESUMO
O texto apresenta as atividades de formação docente desenvolvidas pela matemática, professora e artista plástica Teresa Vergani. De natureza bibliográfica, tem como principais referências os livros de Vergani que expõem suas pesquisas e estudos em contextos socioculturais diversos e o registro de cursos ministrados em Universidades em que atuou como docente. Trata-se de um recorte da tese de doutorado produzida no Programa de Pós-Graduação em Educação da Universidade Federal do Rio Grande do Norte. Os estudos realizados por Teresa Vergani apresentam elementos importantes para a formação de professores, contribuindo para a concretização de uma formação mais contextualizada e transdisciplinar, problematizando de forma ampliada os preceitos de uma educação de base complexa, movida pela atenção às estruturas diversas e universais das culturas e pelo respeito à resistência dos saberes plurais.

Palavras-chave: Teresa Vergani. Formação de Professores. Diversidade Cultural.
\end{abstract}

\title{
INTRODUÇÃO
}

O capítulo é um recorte da tese de doutorado produzida no Programa Pós-Graduação em Educação da Universidade Federal do Rio Grande do Norte. Expõem-se neste texto os estudos e pesquisas da matemática, professora e artista plástica Teresa Vergani acerca da construção plural e inventiva das matemáticas não hegemônicas, apontando para a multiplicidade de saberes exercitados por diferentes estratégias do pensamento. Problematizamos também como as aprendizagens adquiridas em contextos socioculturais diversos servem de matriz para a construção de formações continuadas originais, reflexivas e atinentes com o fazer docente, que extrapolam uma didática instrumental e técnica. Os cursos ministrados por Vergani apresentam uma formação teórico-prática sólida que investem em horizontes mais abertos e transdisciplinares, permitindo esgarçar um pouco mais os limites do conhecimento e da educação.

Ao estudar com profundidade a obra de Vergani, percebemos a natureza cultural, social e transdisciplinar de seus cursos e pesquisas. Esta marca é resultado de sua experiência como consultora da UNESCO, de sua formação e interesse por diferentes áreas do conhecimento e de

\footnotetext{
1 Doutora em Educação pela Universidade Federal do Rio Grande do Norte (UFRN). E-mail: louizegaby@hotmail.com
} 
sua imersão nas culturas africanas e ciganas, o que lhes possibilitou compreender o fenômeno educativo por meio de outras lentes e domínios.

Neste capítulo, apresento brevemente aspectos biográficos da vida e obra de Vergani e algumas experiências profissionais que se constituem um terreno fértil que irradia novas formas de pensar o sujeito, a educação, a diversidade cultural. De natureza bibliográfica, o texto tem como referência principal os livros de Vergani resultantes de disciplinas oferecidas pela autora em cursos de mestrado e formação inicial e continuada de professores.

\section{EXPERIÊNCIAS CULTURAIS E PROPOSTAS DE FORMAÇÃO DOCENTE}

Identificamos cada vez mais cursos que enaltecem a prática em detrimento da teoria, conhecimentos disciplinares fragmentados e desintegrados, formações lineares, técnicas e distantes da realidade dos sujeitos. Nesse contexto, tem se expandido também as reflexões e estudos sobre formação docente com vistas a identificar o que é essencial e primordial no trabalho do professor. As pesquisas acerca dos saberes mobilizados nas práticas pedagógicas embasam estas discussões e apontam que os saberes dos professores estão relacionados com o contexto do seu trabalho, suas experiências de vida e sua história profissional.

Para Tardif (2014), esse saber é plural, heterogêneo e proveniente de fontes diversas, elaborado pelo professor a partir de sua própria atividade. Tais considerações precisam estar no cerne do debate das reformas educacionais, uma vez que,

expressa a vontade de encontrar, nos cursos de formação de professores, uma nova articulação e um novo equilíbrio entre os conhecimentos produzidos pelas universidades a respeito do ensino e os saberes desenvolvidos pelos professores em suas práticas cotidianas (TARDIF, 2014, p. 23).

A docência é uma ação complexa e envolve diversos condicionantes. Esse equilíbrio ao qual o autor se refere potencializa o trabalho do professor que se torna ator de sua prática, tendo consciência das suas escolhas e de sua ação. Teresa Vergani é um exemplo de uma profissional que no exercício de seu fazer docente integra saberes resultantes de fontes diversas: acadêmicas, pessoais, profissionais, pedagógicas.

Maria Teresa Vergani de Andrade nasceu em 1942, na cidade de Lisboa. Foi nesta capital que realizou parte de seus estudos acadêmicos. É licenciada em Ciências da Matemática pela Faculdade de Ciências da Universidade Clássica de Lisboa e em Teologia Pastoral, na cidade de Louvain na Bélgica. Cursou Especialização na Universidade de Genebra e, no ano de 
1983, concluiu seu doutorado na mesma instituição. Sua Tese é considerada interdisciplinar por envolver as áreas de Antropologia, Matemática e Ciências da Educação. No ano de 1990, realizou estudos de pós-doutorado na Universidade de Londres.

Foi consultora da UNESCO na República Democrática de São Tomé e Príncipe, de janeiro a julho de 1977 e, dois anos depois, em 1979, na República Popular de Angola. Nestes países, atuou na formação de professores e na elaboração de programas de cursos intensivos. Exerceu a função de docente nas Universidades de Genebra, Lausanne, Luanda e Lisboa.

Durante esse percurso de formação acadêmica e profissional se deslocou para diferentes lugares do mundo, o que lhe possibilitou recolher fragmentos e saberes de diferentes culturas. Essas experiências suscitaram reflexões sobre o exercício de uma matemática produzida socialmente, dentro de culturas que operam fora da domesticação do conhecimento científico.

Seus deslocamentos pelo mundo se desdobram em curiosidade, exploração, investigação, paixão pelo ato de conhecer. Vergani foi acessando a originalidade humana, manifestada nas crenças, nos costumes, nas raízes mitológicas, na estética e na arte de viver dos povos. Mesmo como uma exímia matemática, não se interessa em reproduzir o discurso que afirma ser esta área voltada mais especificamente ao campo da certeza, da lógica, da dedução. Apesar de reconhecer estas características, suas pesquisas apontam para uma área simultaneamente abstrata, racional, simbólica, pragmática, lúdica, onde o rigor lógico não está divorciado da imaginação criativa.

Exponho a seguir, alguns espaços, lugares, povos e culturas que permitiram Teresa Vergani identificar novas formas de viver, conhecer, ensinar e aprender. Tais vivências serviram de base para a construção de seus cursos de formação, já que suas pesquisas sempre embasaram e alimentaram seu trabalho em sala de aula. Parte dessas experiências foram registradas em seus livros.

Sabemos que o continente africano tem sido ao longo dos séculos palco de várias lutas e conflitos. Durante muito tempo e ainda hoje, o seu povo carrega o estigma de exótico, colonizado, atrasado, diferente. Teresa desconstrói esses estereótipos ao trazer em seus escritos as singularidades e riquezas das culturas, ao mesmo tempo em que vai apresentando as raízes históricas da matemática que abrangem desde sempre todas as identidades culturais, representando a universalidade humana desta área e pondo-a em comunicação com o mundo.

Na cultura Tshokwe de Angola, por exemplo, a complexidade do ato educativo é constituída por um sistema sofisticado de significação globalizante. Arte, mitologia, matemática, oralidade, se juntam para compor narrativas sobre ecologia, relações amorosas, ética, entre outros temas, pois os jovens desta cultura aprendem por meio das narrativas 
centradas em aspectos da vida. Porém, os contos não recorrem apenas à oralidade para serem propagados, mas também ao suporte gráfico e geométrico.

$\mathrm{Na}$ areia, são desenhados ideogramas que complementam a explicação propalada pelo universo da oralidade. Essa escrita na areia, uma espécie de coreografia da oralidade, é transmitida de geração a geração e representa uma memória coletiva ancestral. Os desenhos são feitos a partir da articulação estruturada de pontos e linhas. A singularidade do processo de codificação está alicerçada na abstração geométrica dos traçados e no desejo de duplicação do mundo por esses povos.

A rigorosa configuração do traçado linear confirma a força e a exatidão do sentido da mensagem transmitida, como se a "palavra dita" necessitasse ser reforçada pela "palavra geométrica". A linguagem geométrica confere assim um novo poder à expressão oral, que duplica através dessa nova força a densidade do "dizer", onde a voz se cristaliza em forma espacial construída em consonância com o ritmo profundamente sentido da palavra. Trata-se de uma "coreografia da oralidade". Assim o caráter efềmero da mensagem sonora (que se "perde" no espaço auditivo) ganha uma durabilidade que os olhos podem "ler" (porque gravadas no próprio espaço "físico" que acolhe as linhas do seu traçado). (VERGANI, 2003, p. 82).

Essa experiência foi registrada e tempos depois transformada no livro A palavra e a pedra. A obra traz um misto de imagens, grafismos, cores e poesia. Nele, Teresa ressignifica o desenho que foi gravado na areia, e transforma em telas e pinturas. Este livro apresenta um conteúdo filosófico, espiritual e denota uma ciência como obra de arte.

Estas imagens não são meras reproduções de desenhos rupestres nem simples cópias de expressões ideogrâmicas. Nasceram, sim, de uma ternura interrogativa face à diversidade dos grafismos dos Povos de Angola, palavra rugosa ancestralmente inscrita na gravidade da rocha ou na fluidez da areia. (VERGANI, 1993, p.26).

A expressão ternura interrogativa utilizada por ela para se referir a sua pesquisa com os povos angolanos nos revela a face exuberante, criativa e curiosa de um pensamento que deseja aprender com o diverso e no diálogo com outras vozes e saberes. No livro, imagens e poesias se complementam para dar sentido a narrativa. Ao transformar as imagens em palavras, a autora nos faz enxergar como a arte pode expressar a relação do homem com o mundo. A composição de imagens e poemas explicita uma forma de falar dos fenômenos e representa uma visão de mundo mais arcaica e artística, que expressa uma estética universal do pensamento destes povos. 
A estética, a poesia e o deslumbramento são características que, infelizmente, aparecem de forma tímida nas escolas. Cada vez mais as instituições de ensino visam resultados, eficiência e quantidade. É nosso papel, enquanto educadores, restaurar os elos de um saber escolar que dialoga com a arte. É preciso recuperar esses estados de ser para fazer da vida a própria arte. Isso é resistência, é insubordinação, é ousadia. Para Morin,

O estado estético é um transe de felicidade, de graça, de emoção, de gozo e de felicidade. A estética é concebida aqui não somente como uma característica própria das obras de arte, mas a partir do sentido original do termo, aisthétikos, de aisthanesthai, 'sentir'. Trata-se de uma emoção, uma sensação de beleza, de admiração, de verdade e, no paroxismo, de sublime; aparece não somente nos espetáculos ou nas artes, entre os quais, evidentemente, a música, o canto, a dança, mas também nos odores, perfumes, gostos dos alimentos ou das bebidas; origina-se no espetáculo da natureza, no encantamento diante do oceano, da montanha, do nascer do sol. Pode vir mesmo de obras sem qualquer finalidade estética inicial, como os antigos moinhos de vento ou as antigas locomotivas a carvão. Também os objetos mais técnicos, como o automóvel e o avião, podem vir a ter carga estética (MORIN, 2012, p. 132).

Se reconhecermos que somos uma obra de arte inacabada, que vai sendo constantemente remodelada, precisamos assumir nossa responsabilidade de fazer surgir camadas escondidas em nossos alunos, realçando o que de mais belo eles guardam em potencial criativo. O sistema educacional deve investir no patrimônio cognitivo de cada estudante de modo a contribuir com o pleno emprego da inteligência geral (MORIN, 2003).

Outras experiências importantes de inserção de Teresa entre os povos africanos estão registradas no livro Excrementos do Sol: a propósito de diversidades culturais. Nesta obra, a autora traz reflexões profundas e instigantes sobre diversidades culturais, oralidade, linguagem, cultura Dogon, cigana, entre outras. Estes temas e as reflexões contidas no material são decorrentes de uma disciplina ministrada por ela no curso de Mestrado de Relações Interculturais oferecida pela Universidade Aberta de Lisboa, em 1993. No livro, é possível encontrar uma matriz importante do pensamento de Teresa, no qual arte, espiritualidade, cultura, poesias e autores de diferentes pertencimentos disciplinares fazem parte da composição do material.

Entre os povos Dogon, a linguagem transcende a função redutora e utilitária que a caracteriza como sendo responsável por nomear e indicar os objetos. Nesta cultura, as palavras apresentam um caráter híbrido e agregam múltiplos sentidos. Os vocábulos assumem conotações diferentes que se desmembram para responder em sua totalidade os sentidos que são atribuídos. Para os Dogon, as palavras são classificadas segundo valores morais, podem ser 
masculinas ou femininas e apresentam uma característica afetiva. Existem, por exemplo, as palavras mortas (que são as responsáveis por exalar mau cheiro); as sem semente (incompreensíveis); as brancas (que demonstram sinceridade e transparência); as frias; quentes; vivas, dentre outras.

Entre as culturas africanas, além de algumas palavras se dividirem por categorias, também são encontrados diversos vocábulos para designar um único fenômeno. Na língua africana cinyanja, por exemplo, a diversidade lexical leva a necessidade de detalhar seus sentidos gerando assim diferentes vocábulos para designar uma palavra. Quando se fala a palavra cova (abertura no terreno, escavação profunda) é necessário esmiuçar seu significado. Segundo Teresa Vergani, “dizer cova diz muito pouco. É preciso escolher a palavra que indica se é grande ou pequena, se é feita para capturar caça ou para sepultar alguém, se serve para plantar uma árvore ou desenterrar um tesouro" (VERGANI, 1995, p. 60).

De acordo com Vergani, conhecer o profundo significado sociocultural das expressões tradicionais a seduz e abre-lhe dimensões novas, não reveladas. Acessar a língua do outro é para ela como penetrar na intimidade de alguém.

As aprendizagens e vivências de Teresa Vergani com as culturas africanas ampliaram seu olhar mediante o conhecimento, potencializando sua curiosidade por conhecer lugares disciplinares até então desconhecidos. Como uma nômade das ideias, rompeu as barreiras e limites das especializações e exercitou o que Edgar Morin chama de migrações conceituais ${ }^{2}$. Por este e outros motivos, podemos afirmar que a autora tem uma grande contribuição a oferecer à educação. Mesmo interrogando e questionando a forma como se "transmite" o conhecimento e a cultura pelos espaços formais de aprendizagem, promoveu diversos cursos de formação de professores que, para ela, reverberam mais como uma experiência de terapia do que como um receituário descontextualizado que ensina como fazer.

Das várias formações que ministrou, uma merece destaque. Oferecida a alunos do $1^{\circ}$ ano do curso de professores do ensino básico, o curso foi transformado em uma disciplina da Escola Superior de Educação de Setubal e foi para Teresa "um contra-espaço de reflexão, na medida em que formulou um tempo para ter tempo e funcionou como uma experiência de terapia (no sentido de um oásis onde se apagam os medos)" (VERGANI, 1991, p. 14).

Esta experiência de formação foi relatada no livro $O$ zero e os infinitos. Já nas primeiras páginas, a autora vai lançando reflexões acerca da angústia vivenciada por muitos professores que, para cumprir os conteúdos julgados importantes, correm contra o tempo, acelerando a

\footnotetext{
${ }^{2}$ Para o autor, os conceitos devem sair de sua especialidade mais fechada e migrar para outras áreas do conhecimento.
} 
apresentação das informações e temas. Como consequência, esse modo de fazer contribui para uma formação de consumidores passivos de conteúdos. Como se estivessem em uma esteira de produção semelhante ao sistema toyotista, os alunos recebem inúmeras informações, mas nem sempre conseguem transformá-las em conhecimento. Um parêntese se faz aqui necessário para apresentar e problematizar as discussões de Almeida (2017) sobre informação, conhecimento e sabedoria e como estas concepções se apresentam em nossa sociedade, mais especificamente nas instituições educacionais.

Almeida faz um alerta acerca do uso recorrente das três palavras como se expressassem o mesmo sentido. Para ela, conhecimento é tratamento de informações, é "manipulação cognitiva, trabalho artesanal do pensamento" (2017, p. 69). A autora usa a imagem do oleiro para exemplificar o exercício feito pelo nosso pensamento quando dá forma e trata a informação que recebemos, ouvimos e apreciamos. Portanto, não basta ter acesso a uma quantidade excessiva de dados, se não for oferecido tempo para maturá-los e ruminá-los.

Diariamente recebemos uma avalanche de informações que nos chegam por meio da mídia, das redes sociais e por diferentes artefatos. Com o fenômeno da "democratização do acesso" à internet (ou imposição do acesso) temos em nossas mãos informações sobre os mais variados temas e assuntos. Essa facilidade tem também suas desvantagens, principalmente quando as reproduções e compartilhamentos desmedidos das fake news parecem se avolumar entre nós. Ao darmos um passo para trás com o intuito de avaliarmos nossas chances de mudanças desse cenário, percebemos que ele parece sem volta, sendo necessário assim criarmos rotas de fuga e pequenas ilhas de resistência. Como nossas escolas repetem o mesmo padrão da sociedade a qual está inserida, o desafio do educador parece ser ainda maior. É preciso oferecer uma experiência de formação para os estudantes digerirem paulatinamente a informação que lhes está sendo apresentada, ao mesmo tempo que lhes permitam ver além das telas. A escola não pode ser vista como um espaço de adestramento das aptidões humanas e da aprendizagem apenas das capacidades cognitivas. Em relação a sabedoria, Almeida concebe como,

Um jeito de viver e sentir do pensamento; uma maneira de falar do mundo que associa simplicidade e parentesco, coragem e afeto, vontade de verdade e consciência da incompletude e do erro. Sendo maior, mais plena, mais essencial e duradoura, a sabedoria não se reduz a um conjunto de conhecimentos. (ALMEIDA, 2017, p. 70).

Ora, em uma sociedade na qual as informações se multiplicam de modo excessivo, não dando chances para que os sujeitos as processem e transformem em conhecimento, como tornar 
o que tem sido da ordem do fugaz e do instantâneo em sabedoria? Eis mais um desafio para o educador. Para aprender, os estudantes precisam integrar e organizar, em sua estrutura cognitiva, os conteúdos que lhes são apresentados. Quando o professor associa os conceitos novos com o repertório que o aluno já possuía, a aprendizagem acontece de forma significativa, conforme defende David Ausubel. Se o aluno só recebe informações desconexas e em abundância, esse processo não acontece de forma efetiva, dando margem a uma aprendizagem mecânica, automática e memorística.

Parece ter sido essa a senha que fez Teresa escolher um outro modo de abordar os conteúdos de sua disciplina. O curso que ofereceu procurou ser um espaço de desafogo intelectual, tendo como principal função despertar os alunos para uma matemática entendida como fenômeno fundamentalmente humano. Vergani afirma no livro que o curso "pretendia ser um espaço de libertação de preconceitos acumulados e de desdramatização de conflitos por resolver nesta área disciplinar, num convite à confiança, ao sucesso e à funcionalidade" (1991, p. 16). Para dar conta destes objetivos, se lançou na exposição dos diferentes modelos lógicos e expressões matematizantes do pensamento tradicional de povos de várias partes do mundo.

Vários temas foram discutidos nas aulas: pensamento racional e simbólico; criatividade; as expressões matematizantes dos povos das diferentes civilizações; a concepção de zero e infinito, entre outros. Os primeiros 15 minutos de cada aula eram reservados para os alunos compartilharem conhecimentos daquilo que julgassem interessantes.

Outro aspecto importante que contribuiu para o bom desenvolvimento da disciplina foi a atenção da professora com os estudantes. Partindo sempre das perguntas formuladas por eles e de seus núcleos de interesse, Teresa oferecia apoio aos projetos de estudos individualizados e grupais. Ao longo das aulas, novas curiosidades iam surgindo, e para dar conta dessas novas demandas, a professora foi lançando mão de temas optativos.

Ao final da disciplina, foi aplicado com os alunos um questionário que versava sobre a pertinência dos temas de estudo, possíveis ajustes e sugestões de mudanças. Para o encerramento dos trabalhos, foi proposta uma exposição de obra de arte no fim do ano com o título "A imaginação do passado". O material foi produzido por Teresa e inspirado nos temas das aulas.

\section{CONSIDERAÇÕES FINAIS}

Conhecer e se aprofundar nos estudos e pesquisas de Vergani nos mostra o quanto ao aprendermos com o outro, alargamos a compreensão sobre nós mesmos. Infelizmente, o nosso 
sistema educacional opera o contrário. Procura uniformizar e padronizar as falas, experiências e ações dos estudantes de modo a apagar as diferenças e a riqueza entre eles.

Para a pesquisadora, surpreender-se com o mundo deveria ser uma das lições sine qua non ensinadas por professores e vivenciadas pelos estudantes no interior das escolas. Tal condição poderia fazer desabrochar as potencialidades do sujeito, fazendo-os não sucumbir diante das facilidades das respostas prontas e da rotina, por vezes tão monótona, do ensino. A escola deve cada vez mais oferecer uma formação que permita aos estudantes desenvolverem sua curiosidade e imaginação, ensinando-os a olhar o mundo como um espaço de descobertas e aventuras a ser experimentado por todos nós, com ética, zelo, respeito e cuidado. É necessário assegurar a aprendizagem autônoma e efetiva, de modo que todos possam julgar e pensar por si mesmos.

Para o filósofo John Dewey (1959), a escola deveria preparar os alunos para questionarem a realidade, para saber viver bem no mundo e para resolverem problemas reais da vida comum. Em sua concepção, a educação é uma constante reconstrução da experiência e para tanto é preciso oferecer condições para que os estudantes façam uso da experimentação, do intercâmbio, da troca de ideias e da reflexão crítica. Tais pontos eram para Dewey fundamentais para uma aprendizagem mais efetiva, real e significativa.

Teresa sabe bem disso e vai para África conhecer as culturas e aprender com elas. Mesmo quando foi convidada para trabalhar como consultora da UNESCO e colaboradora do Projeto Nómada, participando da construção de materiais para a formação de professores de crianças da etnia cigana, ela vai por outro caminho. Não estava preocupada em transmitir conhecimento, aliás, esse termo é inapropriado para pensar uma educação na qual os alunos são partícipes de todo o processo, se afinando muito mais com um modelo mecânico que admite ser o aluno um receptor passivo de informações, fruto de uma concepção de educação bancária, criticada tantas vezes por Paulo Freire. Como o conhecimento se compartilha e se constrói, Teresa vai na direção de apreciar, dar visibilidade, ampliar, compartilhar os saberes e experiências vividas.

Sabemos o quanto a aprendizagem é um processo complexo e que envolve múltiplos condicionantes. Cada ser humano é singular, aprende de uma forma e em um ritmo diferente, para isso necessita do outro para ajudar a se apropriar dos conhecimentos já sistematizados pela sociedade, atribuindo significado às coisas ao seu redor e inserindo-o no universo da cultura, não simplesmente para reproduzi-la, mas para transformá-la por meio de princípios que digam respeito às coisas da conjunção e não da competição. 
Aprender implica interação, participação ativa, respeito e abertura em relação ao que o outro tem a oferecer, requer aproximar o aluno de uma diversidade de estratégias didáticopedagógicas para fomentar uma aprendizagem mais eficaz. A aprendizagem se processa em diversos contextos, formais ou não, de forma sistemática ou espontânea. Vergani nos ensinou em vários momentos que estamos aprendendo o tempo todo, em situações tão plurais que nos tornam eternos aprendizes. Não existe idade certa para aprender, nem tão pouco faz sentido analisar os fracassos, os insucessos, as dificuldades, se tomamos como prisma um modelo de educação que privilegia uma única verdade, linguagem, narrativa.

Como uma das várias lições aos professores, Teresa Vergani mostrou que aprender não é um processo mecânico, passivo e descontextualizado, pois exige curiosidade, espírito investigativo, ousadia para escutar e olhar o mundo. Para que isso possa vir à tona, é preciso fomentar práticas propulsoras do desenvolvimento do sujeito que contribuam para o pleno emprego da inteligência geral, conforme deseja Edgar Morin.

A metáfora da arte utilizada por Ilya Prigogine para falar da ciência que o século XX inaugurou, pode servir também para pensar a educação. Ao ser entendida como uma obra de arte, como um espaço para fazer despertar os processos criativos dos sujeitos, a educação deveria captar a sensibilidade dos alunos, fazendo-os expressarem suas percepções e sensações por meio da escrita, da oratória, dos desenhos, dos trabalhos escolares, dos recursos que lhes são disponibilizados. Desse modo, as escolas estariam contribuindo para o desenvolvimento de uma formação integral e, ao mesmo tempo, propiciando lugares cognitivos mestiços para serem experimentados pelos estudantes. A diversidade de lugares cognitivos requer nessa perspectiva um recrutamento e revalorização dos saberes que nos precederam por algumas gerações. Tais saberes contêm princípios, éticas e horizontes imaginativos capazes de alertar para o perigo da negação contínua da história que passou.

As pesquisas desenvolvidas por Vergani apontam para o exercício de um diálogo entre as culturas. As práticas socioculturais dos povos demonstram a pluralidade e universalidade das culturas humanas, o que denota descortinar os discursos que explicitam a hegemonia de povos e saberes.

As reflexões apontam que é no campo da incerteza que podemos criar, dar novos saltos; reconhecer que as verdades são sempre parciais e que não podemos desconsiderar as verdades dos outros contextos e narrativas; valorizar as diversas versões dos fenômenos, pondo-as em diálogo, de modo que um saber não exclua o outro, nem se sobressai com a justificativa de ser entendido como o mais importante; exercitar formas de religar parte e todo, local e global, vida e ideias, ciência e tradição e os diferentes domínios do conhecimento; arriscar-se em sair fora, 
ir no contrafluxo do estabelecido; apreciar o diverso como uma de nossas maiores riquezas; e, por fim, despertar nos sujeitos o prazer pelo ato de conhecer.

\section{REFERÊNCIAS}

ALMEIDA, Maria da Conceição de. Complexidade, saberes científicos, saberes da tradição. 2. ed. São Paulo: Editora Livraria da Física, 2017.

DEWEY, John. Democracia e educação: introdução à filosofia da educação. 3. ed. São Paulo: Nacional, 1959.

MORIN, Edgar. O Método 5: a humanidade da humanidade, a identidade humana. 5. ed. Porto Alegre, 2012.

A cabeça bem feita: repensar a reforma, reformar o pensamento. Rio de Janeiro: Bertrand Brasil, 2003.

PRIGOGINE, Ilya. Do ser ao devir: nomes de deuses: entrevistas a Edmond Blattchen. São Paulo: Unesp; Belém: UEPA, 2002.

TARDIF, Maurice. Introdução. In: . Saberes docentes e formação profissional. Petrópolis: Vozes, 2014.

VERGANI, Teresa. A surpresa do mundo: ensaios sobre cognição, cultura e educação. Natal: Flecha do Tempo, 2003.

Excrementos do sol: a propósito de diversidades culturais. Lisboa: Pandora, 1995. (Olhos do Tempo).

A palavra e a pedra. Lisboa: Universidade Aberta e Teresa Vergani, 1993.

O zero e os infinitos: uma experiência de antropologia cognitiva e educação matemática intercultural. Lisboa: Minerva, 1991. 


\title{
https://doi.org/10.36470/famen.2020.14c9 \\ PEDAGOGIA SOCIAL: DA INCLUSÃO SOCIAL À ESCOLAR
}

\author{
Edna Oliveira da $\mathrm{Paz}^{1}$
}

\section{RESUMO}

Este trabalho se constitui de uma experiência em educação não formal no contexto de inclusão de educandos com dificuldades de aprendizagem e defasagem escolar. Aqui procuramos contextualizar a pedagogia social e refletir sobre os problemas de aprendizagem que a escola formal não tem conseguido resolver, gerando assim uma busca por espaços não formais que trabalham a aprendizagem com metodologias diferenciadas e devolvendo aos educandos a autoestima perdida e o retorno à escola no enfrentamento das dificuldades de aprendizagens e inclusão dos alunos não alfabetizados na idade certa. A pesquisa apresenta uma abordagem da historicidade da pedagogia social, da educação inclusiva e a defasagem escolar. Constitui-se numa pesquisa de caráter qualitativo, cujos sujeitos são alunos do ensino fundamental. Primeiro aplicou-se um questionário com perguntas abertas e fechadas e a interpretação dos dados foi realizada por meio de uma metodologia de abordagem qualitativa associada à quantitativa. Os resultados sinalizam às realidades encontradas pelos alunos com dificuldades de aprendizagens diante dos diversos desafios que vivenciam no dia a dia.

Palavras-chave: Pedagogia social. Inclusão. Aprendizagens. Educação.

\section{A PEDAGOGIA SOCIAL E EDUCAÇÃO}

Nos cursos de Pedagogia no Brasil, a discussão sobre Pedagogia Social ainda é pouco desenvolvida. Somente há poucas décadas os cursos de pedagogia e as universidades brasileiras começaram a se voltar para o estudo dos segmentos historicamente excluídos. Embora os documentos das Políticas Educacionais brasileiras contemplem a democratização da educação e a qualidade de ensino para todos os cidadãos, ainda existem contradições e distanciamentos significativos entre as leis e as práticas realizadas.

As demandas educacionais e sociais estão exigindo uma nova concepção de educação. Os estudos da Pedagogia apontam essas novas discussões sobre o papel da Educação na formação dos sujeitos historicamente excluídos. Essas discussões nos fazem pensar em uma análise da história do Curso de Pedagogia e das diretrizes, porém em outro momento, já que neste nos deteremos a falar sobre as ações de inserção da Pedagogia Social no curso de Pedagogia.

As Diretrizes Curriculares Nacionais (BRASIL, 2005) trouxeram avanços no que diz respeito às discussões e valorização das minorias excluídas e a defesa dos seus direitos básicos. Esse documento revela que a inclusão desta temática na formação do Pedagogo está propiciando

\footnotetext{
${ }^{1}$ Especialista em Atendimento Especializado Educacional pela Universidade Federal do Ceará - UFC e em Gestão Pública Municipal pela Universidade Federal da Paraíba - UFPB. E-mail: edinha.paz@outlook.com
} 
o respeito a diversidade dos educandos e valorização de suas identidades. Estas questões estão retratadas no próprio documento do Ministério da Educação.

Grande parte dos Cursos de Pedagogia hoje tem como objetivo central à formação de profissionais capazes de exercer a docência na Educação Infantil, nos anos iniciais do ensino Fundamental, nas disciplinas pedagógicas para a formação de professores, assim como para a participação no planejamento, gestão e avaliação de estabelecimentos de ensino, de sistemas educativos escolares, bem como organização e desenvolvimento de programas não-escolares. Os movimentos sociais também têm insistido em demonstrar a existência de uma demanda ainda pouco atendida, no sentido de que os estudantes de Pedagogia sejam também formados para garantir a educação, com vistas à inclusão plena dos segmentos historicamente excluídos dos direitos sociais, culturais, econômicos e políticos (BRASIL, 2005, p.5).

Graciani (2006) afirma que os estudantes de Pedagogia precisam ser formados para garantir a educação, com vistas à inclusão plena dos segmentos historicamente excluídos dos direitos sociais, culturais, econômicos e políticos. Esta concepção de formação do pedagogo voltada para o aspecto social, proporciona os meios necessários para que os sujeitos historicamente excluídos reflitam criticamente sobre o contexto no qual estão inseridos e reivindiquem seus direitos como cidadãos. Nesse sentido, a educação possui um papel fundamental na constituição da sociedade e a Pedagogia é um instrumento significativo na formação e constituição destes sujeitos.

O que observamos é um momento de criatividade pedagógica mais que de sistematização dos conteúdos e dos métodos. Em outras palavras, temos no Brasil educadores que colaboram com o nascimento e o desenvolvimento de uma metodologia com identidade própria, rica de intuição pedagógica e de conteúdo. Ao mesmo tempo nos damos conta de que é chegado o momento no qual precisamos sistematizar toda essa gama de conhecimentos pedagógicos para compreender melhor e interpretar a realidade e projetar intervenções educativas efetivas.

\section{CONTEXTUALIZANDO ALGUMAS DIFICULDADES DE APRENDIZAGEM ESCOLAR}

Segundo Moojen (1999), os problemas na aprendizagem podem ser divididos em duas categorias: os transtornos específicos de aprendizagem (decorrentes do processo de desenvolvimento neurológico) e as dificuldades escolares, que podem estar relacionadas a patologias clínicas, a problemas ambientais e de método de ensino.

A dificuldade específica de aprendizagem caracteriza-se por um funcionamento abaixo do esperado, considerando a idade cronológica e o quociente intelectual do educando, além de, 
interferirem-no rendimento escolar e na vida cotidiana. Para Russo (2015), explicar o mecanismo de aprendizagem é esclarecer a maneira pela qual o ser humano se desenvolve, conhece o mundo em que vive, se organiza e se ajusta ao meio físico e social.

Sobre os requisitos para o diagnóstico citamos dois que Moojen (1999) destaca: a dificuldade de diagnóstico dos transtornos específicos de aprendizagem depende das circunstancias familiares e da escolaridade, bem como das características individuais dos educandos; as dificuldades escolares podem ser decorrentes de problemas sociais, doenças crônicas, distúrbios psiquiátricos, problemas familiares, uso de medicamentos, professores desmotivados e despreparados entre outros.

No atendimento pedagógico, o educador deve ficar atento para os requisitos necessários para a aquisição das novas habilidades, por exemplo, nas dificuldades de aprendizagem de leitura e escrita tem-se que considerar a prontidão para a alfabetização, que significa ter o nível suficiente para iniciar o processo da função simbólica, que é a leitura, e sua transposição gráfica, que é a escrita (MORAIS, 1986). O preparo para iniciar a alfabetização depende da integração dos processos neurológicos e de uma harmoniosa evolução de habilidades como percepção, esquema corporal, lateralidade, entre outros. Para o desenvolvimento da escrita é necessário o desenvolvimento da linguagem oral, das habilidades de orientação espacial e temporal, coordenação visomotora, memória visual e auditiva e motivação para aprender.

Segundo Russo (2015), nas crianças que sofremde discalculia, a capacidade de adquirir as habilidades matemáticas está seriamente prejudicada. Elas não conseguem lidar com o conceito de número, e as situações que envolvem matemática tornam-se um problema na escola e nas atividades cotidianas, porém para compreender os conceitos matemáticos, além dos já citados para a escrita, a criança deve saber seriar, agrupar e representar, aspectos estes negligenciados por muitas escolas.

Para a intervenção dos problemas de aprendizagem, sejam neurológicos, relacionados a patologias, ou formação reativa à escola, faz-se necessário o desenvolvimento psicomotor, observando a evolução normal e os sintomas de distúrbios. Segundo Russo (2015), a educação psicomotora tem por finalidade assegurar o desenvolvimento funcional, observando as possibilidades da criança, e ajudar sua afetividade a se expandir e se equilibrar, por meio do intercâmbio com o meio ambiente. O brincar nesse processo de intervenção é utilizado como forma de explorar as funções cognitivas e de trabalhar aspectos do comportamento afetivo e social da criança. 


\title{
A PEDAgogia SOCIAL E SUA CONTRIBUIÇÃO NA FORMAÇÃO DO(A) PEDAGOGO(A)
}

No percurso de formação e constituição da identidade docente existem inúmeras possibilidades que se apresentam como potencializadoras do trabalho pedagógico, oportunidades que consistem em melhorar e humanizar os processos de ensino-aprendizagem, diante da diversidade de caminhos que existe. A experiência vivenciada, através da prática no âmbito da sala de aula, nos permitiu confrontar as teorias apreendidas na academia e compreender que a prática docente se constitui no âmago da sociedade, na necessidade de ensinar e aprender coletivamente, de fazer-fazendo, na possibilidade dialógica de compreender o outro como parte de nós.

Essa concepção formativa é concebida no processo de formação inicial quando a relação teoria e prática é entendida como oportunidade de aprender junto a sociedade, sendo a teoria a forma como o conhecimento se apresenta e a prática como a materialização dessa teoria em ações concretas, podendo a partir desse diálogo, modificar-se e modificar as teorias (PACHECO; BARBOSA; FERNANDES, 2017). Nesse sentido, a sala de aula proporciona não só uma relação de reflexão e prática, mas também uma atividade de reelaboração, de ressignificação e autoformação, como apontam Nunes e Silva (2011, p. 126),

\begin{abstract}
A relação entre o ensino e a extensão conduz a mudanças no processo pedagógico, pois alunos e professores constituem-se em sujeitos do ato de aprender. Ao mesmo tempo em que a extensão possibilita a democratização do saber acadêmico, através dela, esse saber retorna à universidade testado e reelaborado. A relação entre pesquisa e extensão ocorre quando a produção do conhecimento é capaz de contribuir para a transformação da sociedade. A extensão como via de interação entre universidade e sociedade constitui-se em elemento capaz de operacionalizar a relação entre teoria e prática.
\end{abstract}

A prática de sala de aula, nessa perspectiva, envolve relações sociais e humanas entre professores, estudantes e a comunidade, relações que não sendo neutras, têm objetivos específicos vinculados aos processos de aprendizagem, construindo-os com sentido e contribuindo, assim, para as transformações necessárias (ALMEIDA; SAMPAIO, 2010).

Nessa acepção, é oportuno dizer que as experiências vivenciadas no âmbito da sala de aula, constituíram-se enquanto referências experienciais que possibilita-nos repensar cotidianamente a potencialidade de uma mediação pedagógica comprometida com a transformação social do sujeito e do mundo que o cerca. É gratificante saber que cada minuto dedicado às atividades foi como sementes plantadas em terreno fértil. É por isso que "ensinar exige convicção de que a mudança é possível" (FREIRE, 2017, p. 74), porque de fato é possível, mas para que consigamos transformar 
o mundo do outro, antes é preciso que transformemos o nosso. Refletir metodologicamente e compreender sistematicamente a potencialidade docente nesse processo de intervenção corrobora não só para a constituição de uma identidade pedagógica humanizada, mas também para uma prática socioeducativa significativa.

Neste contexto, a Pedagogia Social aqui vivenciada está compromissada com o desenvolvimento integral tanto do educador quanto do educando, materializando isso diariamente nos encontros. Estar em contato com as crianças semanalmente fez-nos refletir criticamente sobre a qualidade da educação que oportunizamos, as metodologias que podemos praticar, as estratégias que podemos utilizar, tanto para estimular a atenção das crianças quanto para sensibilizá-las sobre a importância de participar das atividades propostas. É por esse aspecto que a extensão pode ser caracterizada como "um processo de aprendizagem vivencial, reflexivo e dialógico, de formação humana, social e profissional" (MENEZES, 2010, p. 14).

O aperfeiçoamento formativo do(a) pedagogo(a) é certamente uma das principais possibilidades que se vislumbra no âmbito da sua prática. Não se trata apenas de ministrar aulas, mas também, a possibilidade de vivenciar as experiências com dedicação, de sentir o abraço de acolhida, de sensibilizar-se a causas nobres, de responder um sorriso com outro sorriso e, acima de tudo, de compreender que sua presença naquele espaço traz alegria e transformação na vida daquelas pessoas. A Pedagogia Social é mais do que um dos espaços para a atuação do(a) pedagogo(a), é a oportunidade de reconhecer a fragilidade do sujeito humano e a possibilidade de abraçá-lo com afetividade.

Essa oportunidade só pode ser proporcionada quando a prática tem o objetivo de transformar, não apenas de investigar, de conhecer, de coletar dados que nem sempre tem retorno devendo ser essencialmente uma possibilidade de inserir-se na sociedade com o objetivo de estabelecer relações concretas, de contribuir para o desenvolvimento, aprimoramento e transformação do espaço no qual se insere os sujeitos (GARCIA, 2012).

Desse modo, a prática possibilita repensar diariamente estratégias de aprendizagens compartilhadas e dialógicas, metodologias que aprimoram sistematicamente a nossa formação enquanto pedagogos(as) e ressignificam os conhecimentos apreendidos no âmbito acadêmico, conduzindo-nos assim, a problematizações que se apresentam como reflexões e oportunidades singulares de qualificar o processo de constituição de uma identidade pedagógica autêntica.

Assim, a Pedagogia Social, aquela que se realiza noutros espaços educativos para além da escola, evidencia um novo caminho pedagógico, uma outra instância de formação e transformação, oportunizando assim, a possibilidade de uma prática humanizadora que se materializa no campo 
social. A atividade desenvolvida concebe em seu âmago o resultado de um trabalho sustentado na dedicação e no esforço coletivo, no sentimento dos sujeitos atendidos, nos depoimentos motivadores que nos direcionam a prosseguir nesse caminho que vai além de um espaço de atuação, que se caracteriza melhor como espaço de transformação.

Transformar é redimensionar uma prática técnica a uma ação humanizadora, é compreender que o pedagogo é um sujeito que necessita e dispõe de ferramenta potencialmente significativa para a formação cidadã.

Permitiram-nos enxergar vivencialmente o que Freire (2006, p. 25) afirma quando escreve "educar e educar-se na prática da liberdade, é tarefa daqueles que sabem que pouco sabem", ou seja, sabendo que pouco sabemos procuraremos saber mais, compreendendo os desafios encontrados como oportunidades autoformativas de crescimento profissional, humano, político e social.

Portanto, as experiências vivenciadas constituem-se como práticas pedagógicas sociais que contribuíram sistematicamente para a formação, profissionalização e progresso dos educandos envolvidos.

\section{CONSIDERAÇÕES FINAIS}

A Educação é um processo que ocorre nos mais diferentes âmbitos da sociedade em se tratando de espaços formais e não formais. Neste sentido, os cursos de Pedagogia e seus formadores precisam estar atentos para formar educadores para atuar nestes vários espaços. Acreditamos que todas as formas de Educação possuem um aspecto relevante, pois, agem perante sujeitos sociais e históricos e fazem parte da constituição dos mesmos. Por isso, faz-se necessário avaliarmos de que forma estas atuações vem ocorrendo nos cursos de Pedagogia e como os pedagogos estão sendo preparados para refletir e atuar na Educação nas suas múltiplas formas de acontecer.

A Pedagogia enquanto instrumento da Educação e a sua dimensão social, precisa ser discutida cotidianamente. O que observamos durante as atividades desenvolvidas é que os alunos que chegam vêm de meios educacionais excludentes, uma escola básica onde o trabalho educativo requer o conhecimento dos diversos aspectos relacionados aos componentes sociais, além dos aspectos cognitivos e aprendizagem escolar. Através das avaliações e intervenções realizadas, podemos localizar e compreender o comportamento dos educandos, interesses, preocupações, conflitos e necessidades. Aspectos estes da organização interna da criança, assim como de sua compreensão do mundo, da vida social e familiar, o que nos possibilitou o reconhecimento de 
problemas e sua possível intervenção. Restando a escola reconhecer esses aspectos e cumprir sua missão educativa e social para com esses educandos.

A intenção deste capítulo foi trazer breves considerações sobre os processos de defasagem ensino-aprendizagem e contextualizá-los à Pedagogia Social, posto que os educandos são de classe desfavorecidas, vivendo de programas sociais, de lares mantidos alguns somente pela mãe, outros pelos avós ou tios, alguns por dependentes químicos, entre outros problemas sociais que de alguma maneira podem ter agravado a situação educacional desses educandos.

Pela análise das atividades e resultados obtidos, vemos que é possível a realização de adequação das atividades escolares, refletindo no aumento da participação dos educandos na escola. Porém, ainda vemos um caminho a trilhar quando a procura por esses espaços cresce a cada dia e o discurso dos que estão na escola são de que estes educandos têm problemas. Na realidade, temos uma escola adoecida que não se reconhece doente, gerando um ciclo de exclusão. Acreditamos que este texto possa contribuir com o despertar de discussões futuras sobre o tema tanto no curso de Pedagogia como nas demais licenciaturas.

\section{REFERÊNCIAS}

ALMEIDA, Luciane Pinho de; SAMPAIO, Jorge Hamilton. Extensão Universitária: aprendizagem para transformações necessárias no mundo da vida. Revista Diálogos: construção conceitual de extensão e outras reflexões significativas. Brasília, n.1, v. 14, dez. 2010. p. 33-41.

BRASIL. Lei de Diretrizes e Bases da Educação Nacional. Lei n. 9.394, 20 de dezembro de 1996.

Parâmetros curriculares nacionais: introdução aos parâmetros curriculares nacionais / Secretaria de Educação Fundamental. - Brasília: MEC/SEF, 1997. 126p.

DAVIS, C.; OLIVEIRA, Z. M. T. Psicologia na Educação. São Paulo; Cortez 1994.

FAGALI, E; VALE, Z. Psicopedagogia Institucional Aplicada: aprendizagem escolar dinâmica e construção na sala de aula. 10. ed. Petrópolis, RJ: Vozes, 2009.

FREIRE, Paulo. Extensão ou comunicação? 13 ${ }^{a}$ ed. São Paulo: Paz e Terra S/A, 2006.

Pedagogia do Oprimido. 64ª ed. São Paulo: Paz e Terra, 2017.

Pedagogia da autonomia: saberes necessários à prática educativa. $55^{\mathrm{a}}$ ed. São Paulo:

Paz e Terra, 2017 
GARCIA, Berenice Rocha Zabbot. A contribuição da extensão universitária para a formação docente. 2012. 115f. Tese (Doutorado em Educação - Psicologia da Educação) - Pontifícia Universidade Católica de São Paulo, São Paulo, 2012.

GRACIANI, M.S.S. Pedagogia social: impasses, desafios e perspectivas em construção. In: I Congresso Internacional de Pedagogia Social, 1, 2006, Anais eletrônicos. Faculdade de Educação, Universidade de São Paulo, Disponível em: http://www.proceedings.scielo.br Acesso em: 10 fev. 2020 .

MENEZES. Ana Luisa Teixeira. Extensão: por uma percepção de um conhecimento biocêntrico. Revista Dialogos: construção conceitual de extensão e outras reflexões significativas, Brasília, n. 1. v. 14, dez. 2010. p. 8-15.

MOOJEN, Sonia. Dificuldades ou transtornos de Aprendizagem. In: RUBINSTEIN, Edith. Psicopedagogia: uma prática, diferentes estilos. São Paulo: Casa do Psicólogo. 2012.

MORAIS, A. M. E. Distúrbios de aprendizagem. São Paulo: Edicon, 1986.

NUNES, Ana Lucia de Paula Ferreira; SILVA, Maria Batista da Cruz. A extensão universitária no ensino superior e a sociedade. Mal-Estar e Sociedade, Barbacena, n. 7, v. 4, jul/dez. 2011. p. 119-133. Disponível em: <http://www.uemg.br/openjournal/index.php/malestar/article/view/60/89>. Acesso em: 06 mar. 2020.

PACHECO, Willyan Ramon de Souza.; BARBOSA, João Paulo da Silva.; FERNANDES, Dorgival Gonçalves. A relação teoria e prática no processo de formação docente. Revista de Pesquisa Interdisciplinar, Cajazeiras, n. 2, suplementar, set. 2017. p. 332-340. Disponível em: $<$ http://revistas.ufcg.edu.br/cfp/index.php/pesquisainterdisciplinar/article/view/380>. Acesso em: 06 mar. 2020.

PAIN, Sara. Diagnóstico e tratamento dos problemas de aprendizagem. Porto Alegre. Artmed, 1985.

RUBINSTEIN, Edith. Psicopedagogia: uma prática, diferentes estilos. São Paulo: Casa do Psicólogo. 2012.

RUSSO, Rita Margarida Toller. Neuropsicopedagogia clínica: introdução, conceitos, teoria e prática. Curitiba: Juruá, 2015. 


\section{PROFESSORAS INICIANTES E BEM-SUCEDIDAS: FORMAÇÃO, DIDÁTICA E HABITUS}

Fernanda Oliveira Costa Gomes ${ }^{1}$

\section{RESUMO}

O presente capítulo aborda a temática "a didática de professores iniciantes bem-sucedidos". Os resultados aqui apresentados são parte de uma pesquisa em nível de doutorado, no qual o objetivo foi identificar, junto aos professores iniciantes bem-sucedidos, as disposições presentes nas estratégias e características das ações didáticas para alcançar os objetivos de sua função. Os dados foram analisados a partir de conceitos da área da Sociologia e da Didática. Os referencias teóricos que embasaram a pesquisa foram Bourdieu (1994), Huberman (1992) e Marin (2005, 2014). A discussão realizada traz um aprofundamento acerca das práticas de professoras iniciantes, seus conhecimentos didáticos, assim como a importância de uma formação consistente e a influência do habitus no desenvolvimento do trabalho pedagógico.

Palavras-chave: Formação. Professoras-iniciantes. Didática. Habitus.

\section{INTRODUÇÃO}

O presente capítulo apresenta parte dos resultados de uma pesquisa de doutorado, abordando a temática "a didática de professores iniciantes considerados bem-sucedidos". É importante salientar que o termo bem-sucedido se refere ao sucesso pedagógico e não um sucesso ligado a questões econômicas ou de status. Portanto, destaca-se que obter sucesso na docência não significa a ausência de dificuldades no percurso, mas sim, ter a disposição de criar estratégias para superar os dilemas próprios da profissão.

A pesquisa teve como objetivo identificar, junto aos professores iniciantes bemsucedidos, as disposições presentes nas estratégias e características das ações didáticas para alcançar os objetivos de sua função, e ainda, analisar de maneira detalhada os recursos e ações didáticas utilizadas pelos professores na fase inicial da carreira.

Participaram da pesquisa três professoras iniciantes consideradas bem-sucedidas. As professoras foram indicadas por profissionais da área da Educação atuantes na supervisão, direção e formação de professores. Sendo que duas delas atuavam em salas de recuperação paralela, em uma escola pública da rede municipal da cidade de São Paulo.

Ambas estavam no sexto semestre do curso de Pedagogia, foram contratadas pela rede para atuar nas salas de recuperação, auxiliando alunos do ciclo de alfabetização que apresentavam dificuldades de aprendizagem. Já a outra professora, era concursada na rede municipal da cidade

\footnotetext{
${ }^{1}$ Doutora em Educação: História, Política, Sociedade - PUC-SP. E- mail: proffernanda.sumare@ gmail.com
} 
de São Paulo, e atuava na função de módulo, que consistia em substituir professores ausentes. No entanto, no decorrer da pesquisa, assumiu uma turma de $4^{\circ}$ ano de Ensino Fundamental, já que a regente da turma se afastou do cargo por problemas de cunho familiar.

Os procedimentos metodológicos utilizados para a coleta de dados foram: entrevistas e observações em salas de aulas; e os relatos das professoras, que obtidos por meio das entrevistas, possibilitaram a identificação do habitus. Já as observações foram cruciais para as análises das práticas e didática das professoras. Os dados foram analisados com base em três eixos de análise, sendo eles: as dificuldades, as estratégias didáticas e resultados do trabalho realizado por elas.

A pesquisa foi embasada teoricamente pelos estudos de Huberman (1992), Bourdieu (1994, 2013, 2014), e Marin (2005, 2014). Dos estudos de Huberman foram utilizados os conceitos de Exploração e Estabilização. Este autor realizou um estudo sobre o ciclo de vida dos professores, destacando as fases do início de carreira, a fase intermediária e a fase final da carreira. Já dos estudos de Bourdieu foi utilizado o conceito de habitus, e por fim, foram utilizados os estudos sobre didática de Marin, para realizar as análises das práticas das professoras.

A tese confirmou a hipótese de que a formação no Ensino Superior é essencial para o sucesso no desenvolvimento do trabalho docente, aliado às facetas do habitus desenvolvido pelo indivíduo em outras circunstâncias na composição de disposição da área didática, a partir de saberes contribuindo para o desempenho profissional do professor. Portanto, para se alcançar o objetivo da profissão, que consiste em garantir a aprendizagem dos alunos, se faz necessária uma formação que possibilite os conhecimentos para a autoanálise do trabalho e da prática, a criação de estratégias didáticas e a constante busca pelo conhecimento.

Em tempos em que se ouve falar em "professor com notório saber", e que não é necessário uma formação específica para exercer a profissão, a confirmação desta hipótese é também uma forma de resistência. A função de ensinar não se resume em transmitir conhecimento, portanto, ter um "notório saber" sem conhecimento didático, social, psicológico e político não garante o acesso dos alunos ao conhecimento. $\mathrm{O}$ ato de ensinar é processo formativo, transformador e emancipatório e, portanto, é preciso que um professor tenha a formação didática, social e política para que seus objetivos sejam alcançados.

\section{O INÍCIO NA CARREIRA DOCENTE: UMA DISCUSSÃO NECESSÁRIA}

As pesquisas que abordam o início de carreira têm crescimento modestamente nos últimos anos, no entanto, ainda existem diversas perguntas sobre a temática e muito a se explorar. $\mathrm{O}$ estudo de Mariano (2006) nos confirma o fato de que ainda são incipientes os estudos sobre professores iniciantes. Em sua dissertação, a pesquisadora analisou a produção do conhecimento sobre o 
referido tema, buscando junto às produções da ANPED (Associação Nacional de Pós-Graduação e Pesquisa em Educação) e do ENDIPE (Encontro Nacional de Didática e Práticas de Ensino) trabalhos que abordassem o processo de aprendizagem profissional da docência. $O$ pesquisador traçou um recorte temporal, entre os anos de 1995 até o ano de 2004, e sua análise revelou o modesto crescimento do interesse sobre o tema. Mariano (2006) afirma que foram apresentados um total de 145 trabalhos na ANPED no ano de 1995, sendo que nenhum deles abordava a iniciação à docência. Em 1996, foram apresentados 174 trabalhos e, novamente, nenhum trabalho sobre iniciação docente. Já em 1997, foram apresentados 152 trabalhos, mas apenas um trabalho tratava o tema da iniciação à profissão docente. A pesquisa indica que de 1995 a 2004 foram apresentados um total de 2.314 trabalhos, e destes, apenas quatro discutiam sobre professor em início de carreira.

A análise realizada por Mariano (2006) concluiu que os trabalhos sobre professores iniciantes enfatizavam características como a socialização profissional, os saberes docentes e os sentimentos de sobrevivência e descoberta que marcam fortemente o início da carreira.

Considerando que até o ano de 2004 eram poucos os trabalhos sobre o início da profissão docente, como estaria a produção nos anos seguintes?

Toda pesquisa é considerada relevante por trazer aspectos inéditos, algo novo. Por esse motivo, fora realizada uma busca por trabalhos de mestrado e de doutorado sobre a temática "professores iniciantes". O mapeamento destes trabalhos aconteceu em sites de universidades e no site do Scielo.

No mapeamento foi perceptível que as pesquisas acerca do início da profissão docente referem-se aos seguintes temas: socialização entre pares e alunos; aspectos didáticos na profissão docente; sentimento de sobrevivência na profissão docente; superação de dificuldades na profissão e formação docente; e o curso de Pedagogia. Entretanto, são inexistentes trabalhos que tratam de forma empírica à didática e as práticas de ensino de professores iniciantes, percebendo, portanto, a relevância sobre um estudo que se propõem a realizar uma emersão em sala de aula, buscando compreender quais são as práticas e conhecimentos didáticos que caracterizam um professor bemsucedido em sua função.

Parte das pesquisas sobre iniciantes apresentam as dificuldades, esgotamento, sentimentos de solidão e de sobrevivência. A pesquisa de Gomes (2014) abordou justamente estes fatores, identificando que a professora iniciante desconhecia: o como manejar a sala, sobre o nível de aprendizagem de seus alunos, sobre a Didática, a organização dos conteúdos, o como fazer o planejamento de tempo de aula, como realizar o planejamento das ações durante as aulas, o como 
utilizar a autonomia, o como trabalhar com os métodos propostos pelas escolas, e as noções de psicologia infantil.

Os desafios da profissão docente são de diferentes naturezas e o início de carreira é, geralmente, um momento de descobertas, de erros e acertos, de testar possibilidades, mas algo despertou a curiosidade: alguns professores, mesmo no início de carreira, conseguem desenvolver um trabalho de boa qualidade, e, portanto, podem ser considerados bem-sucedidos. O que eles têm de diferente? Como eles realizam seu trabalho?

Partindo desta curiosidade, a seguinte problemática foi levantada: diante das dificuldades próprias da profissão docente já bastante estudadas, quais são os procedimentos ou estratégias de ensino que professores iniciantes considerados bem-sucedidos utilizam para alcançar os objetivos de sua profissão?

A fim de responder a esta questão, foram realizadas entrevistas e observações em sala de aula de três professoras do Ensino Fundamental I, em escolas municipais da cidade de São PauloSP. As professoras foram chamadas de Júlia, Alice e Sofhia. Estes nomes são fictícios para garantir o sigilo e proteger a identidade das professoras. Esse foi também o procedimento com os nomes dos alunos e escolas apresentadas na tese.

As entrevistas aconteceram durante os momentos de hora atividade das professoras e permitiram apresentar os relatos, experiências de vida, sentimentos, possibilitando identificar o habitus de cada uma delas. Já as observações foram transcritas, respeitando os acontecimentos em sala de aula e interações entre as professoras e seus alunos.

O referencial teórico da pesquisa utilizou os estudos de Huberman (1992) para compreender a fase inicial da carreira. Este autor desenvolveu um estudo sobre o ciclo de vida dos professores, do início ao fim de carreira. A leitura e estudo deste autor foram importantes não só para o desenvolvimento da tese, mas fora uma leitura esclarecedora sobre os dilemas do início de carreira, pois Huberman conseguiu identificar aspectos da carreira docente que grande parte dos professores ainda hoje vivem, e que muitas vezes se sentem sozinhos no percurso, e ao realizar essa leitura foi perceptível que sentimentos como solidão, choque da realidade, sentimento de sobrevivência, exploração e estabilização são fases próprias da carreira.

Dos estudos de Huberman (1992), foram utilizados os conceitos de exploração e estabilização, pois atendem aos objetivos da pesquisa sobre professores iniciantes bem-sucedidos. Segundo Huberman, a fase de exploração,

[...] consiste em fazer uma opção provisória, em proceder a uma investigação dos contornos da profissão, experimentando um ou mais papéis. Se esta fase for positiva passe-se a uma fase de estabilização, ou de compromisso (HUBERMAN, 1992, p. 37). 
Já a fase de estabilização pode ser compreendida como o momento em que,

As pessoas centram a sua atenção no domínio das diversas características do trabalho, na procura de um setor de focalização ou de especialização, na aquisição de um caderno de encargos e de condições de trabalho satisfatórias e, em vários casos, na tentativa de desempenhar papéis e responsabilidades de maior importância ou prestígio, ou mais lucrativas (HUBERMAN, 1992, p. 37).

Ou seja, o momento da exploração é aquele em que os professores se colocam num esforço de testar possibilidades, metodologias, posturas, formas de interação, portanto este momento consiste em "explorar o desconhecido", perceber quais são os melhores caminhos ou os melhores procedimentos. E, portanto, quando os resultados são positivos eles tendem a ser estabilizados, e do contrário poderão ser descartados.

Tais conceitos foram utilizados para identificar como as professoras exploravam este "mundo desconhecido" da escola, do processo de ensino, dos embates que existem na relação com alunos e que de algum modo interfere nos resultados do trabalho, e ainda, tais conceitos permitem identificar quais ações são testadas pelas professoras e consequentemente se tornam permanentes ou descartáveis.

Dos estudos de Bourdieu (1994, 2013, 2014), foi utilizado o conceito de habitus. O autor explicou que "a noção de habitus é uma noção muito antiga, visto que remota a Aristóteles, passando por São Tomás" (BOURDIEU; CHARTIER, 2012, p. 57).

De acordo com o sociólogo francês, o habitus pode ser definido como:

[...] sistemas de disposições duráveis, estruturas estruturadas predispostas a funcionar como estruturas estruturantes, isto é, como princípio gerador e estruturados das práticas e das representações que podem ser objetivamente "reguladas" e "regulares" sem ser o produto da obediência a regras, objetivamente adaptadas a seu fim sem supor a intenção consciente dos fins e o domínio expresso das operações necessárias para atingi-los e coletivamente orquestradas, sem ser o produto da ação organizadora de um regente (BOURDIEU, 1983, p. 61).

E ainda, o habitus pode ser considerado

[...] como um sistema de disposições duráveis e transponíveis que, integrando todas as experiências passadas, funciona a cada momento como uma matriz de percepções, de apreciações e de ações - e torna possível a realização de tarefas infinitamente diferenciadas, graças às transferências analógicas de esquemas, que permitem resolver os problemas da mesma forma, e às correções incessantes dos resultados obtidos, dialeticamente produzidas por esses resultados (BOURDIEU, 1983, p. 65).

O conceito de habitus foi importante para a análise dos dados, pois os agentes têm uma história individual, mas também uma história coletiva; e nesta história, acontece uma incorporação 
de estruturas sociais de categorização de pensamentos e juízos, esquemas de percepção e sistemas de valores. E tal incorporação faz com que o sujeito tenha reações de acordo com o habitus por ele incorporado. Tal fator possibilita a compreensão do como as experiências de vida das professoras poderão influenciar nas suas práticas em sala de aula, no exercício de suas funções. Bourdieu explica que "o habitus trata-se de um sistema aberto de disposições que estará submetido constantemente à experiência e, desse modo, transformando para essas experiências" (BOURDIEU, 2012, p. 62).

Dos estudos de Marin (2005, 2014), foram utilizados as pesquisas sobre didática e, em especial, o conceito de feições da didática, possibilitando identificar quais características e conhecimentos sobre didática, presentes nas ações das professoras.

De acordo com Marin, a Didática apresenta algumas feições que completam o conceito. A feição inacabada consiste em um permanente processo de construção dado que seu objeto constitui um desafio constante na elaboração de um corpo de conhecimentos próprios. As feições operativas, interventiva, orientadora das práticas diárias da Didática são conceituadas como áreas promissoras, capazes de contribuir para a sistematização de conhecimento sobre as ações e operações do complexo processo de ensinar e da forma pela qual elas revelam transformações de conhecimentos para servir a certas funções e condições pessoais e materiais necessários para compreensão das regras ou normas regentes de tais processos, na investigação e no ensino. Feição crítica, reflexiva caracteriza a Didática nos estudos contra dogmatismos e ideias superadas dos saberes puramente intuitivos ou míticos ou, ainda, quando os estudos partem de diferentes pontos problemáticos para o processo de ensinar e aprender sobre o trabalho do professor. Afeição criativa se apresenta quando a Didática se propõe à construção de projetos, objetos e formas de atuar sobre a realidade, desdobrando ou convertendo conhecimentos (sobre a sala de aula, o professor e os alunos) em elementos fundamentais do knowhow necessário ao professor. A feição de eficiência é esperada da Didática, seja para interferir no trabalho do professor em serviço transformando-o, seja para melhor preparo daqueles que pretendem se dirigir ao magistério. Em suma: é preciso "saber fazer bem". Já a feição dialética das perspectivas investigadora e formadora é pressuposta a partir da forma como são concebidas (MARIN, 2005 apud GOMES 2020, p. 57).

Apresentadas as bases teórica, metodológica e de revisão bibliográfica, serão apresentados a seguir os dados e análises resultantes da pesquisa sobre didática de professores iniciantes bemsucedidos.

\section{É POSSÍVEL OBTER SUCESSO NO INÍCIO DE CARREIRA?}

Como fora dito anteriormente, participaram da pesquisa três professoras iniciantes atuantes na rede municipal da cidade de São Paulo, às quais atribuímos os seguintes nomes: Júlia, Alice e Sofhia. Reiteramos que são nomes fictícios a fim de preservar os sujeitos. 
A partir deste momento serão apresentados os resultados da pesquisa. Os dados foram organizados sob três eixos de análise, sendo eles: as dificuldades encontradas no âmbito da sala de aula, as estratégias de superação das dificuldades, e por fim, os resultados do trabalho realizado pelas professoras iniciantes.

\section{AS DIFICULDADES E DILEMAS DO INÍCIO DE CARREIRA}

As professoras Alice e Sofhia trabalhavam na mesma escola e também estudavam na mesma turma do curso de Pedagogia, em uma Universidade particular da cidade de São Paulo. Quando ocorreu a pesquisa, ambas estavam no sexto semestre do curso de Pedagogia. Elas eram responsáveis por turmas de recuperação paralela, em que o objetivo era auxiliar os alunos com dificuldades de aprendizagem, provenientes dos $1^{\circ}, 2^{\circ}$ e $3^{\circ}$ anos do primeiro ciclo do Ensino Fundamental.

Durante as entrevistas ambas relataram que as dificuldades encontradas no início de carreira foram aspectos como: o número elevado de alunos com dificuldade de aprendizagem numa mesma turma, a indisciplina, baixa autoestima dos alunos e falta de auxílio dos colegas docentes.

As salas de aula das professoras de recuperação paralela eram constituídas por um grupo de aproximadamente 20 alunos com dificuldades de aprendizagem. Considerando que o objetivo deste trabalho seria o auxílio dos alunos com dificuldades, o número de 20 alunos por sala dificultou o trabalho das professoras, pois era necessário um acompanhamento minucioso a estes alunos e, muitas vezes particular, para que o objetivo do trabalho se efetivasse.

Outro fator que dificultou o trabalho das professoras foi a indisciplina dos alunos, que também engloba a questão da agressividade e violência entre os discentes. As professoras relataram que a indisciplina prejudica o desenvolvimento das aulas e consequentemente implica na defasagem no desenvolvimento das crianças. Conforme relata uma das professoras:

\footnotetext{
Não era nada fácil. Muitos professores falam que a indisciplina é o não aprendizado, ou seja, o aluno que precisa do reforço são os indisciplinados. E eu percebi que não era bem assim. Nem todo aluno indisciplinado tem dificuldade de aprendizagem. E o que acontecia era que nos mandavam os alunos mais indisciplinados, apenas por serem indisciplinados. (Professora Alice).
}

A baixa autoestima dos alunos que frequentavam as salas de recuperação paralela foi citada como fator preponderante, que influenciou no desenvolvimento do trabalho das professoras. Seus relatos revelaram que uma considerável parcela dos alunos encaminhados para a recuperação se consideravam incapazes de aprender. 
Tivemos que fazer um trabalho de desconstruir alguns preconceitos. Porque o que as crianças nos revelavam era que elas tinham vergonha de ir para o reforço, porque ali eram enviadas as crianças "burras", que não conseguiam aprender. Fizemos um trabalho de desconstruir. E havia professoras titulares que reforçavam esse estereótipo, de que vão para a sala de recuperação os alunos fracos. E haviam crianças que por causa da vergonha, se escondiam para não ir. Eles sofriam bullying por estarem no reforço (Professora Sofhia).

Outra característica que dificultou o trabalho das professoras foi a difícil socialização com seus pares. Em entrevista, a professora Sofhia relatou:

Quando comecei o trabalho com a turma de recuperação a turma era minha. Eu não era mais uma auxiliar. Era uma turma de reforço, mas a responsabilidade era toda minha. Eu e minha colega que trabalhávamos juntas sofremos exclusão, pois as demais professoras da escola não se aproximavam. Teve uma situação em que uma professora chegou a fechar a porta para que nós não escutássemos o que iria ser falado numa reunião pedagógica. Mas, depois as coisas mudaram a ponto de algumas professoras nos pedirem ajuda, com determinados alunos. Aos poucos fomos conquistando nosso espaço e o respeito do grupo (Professora Sofhia).

Já a professora Júlia era concursada e atuava na rede pública na cidade de São Paulo. No momento em que aconteceu a pesquisa, ela cumpria a função de professora de módulo, isto é, ela substituía professores ausentes. Entretanto, após alguns meses, a professora Júlia assumiu uma turma do quarto ano do Ensino Fundamental, pois a professora da turma se afastou temporariamente por motivos familiares. A professora se formou em uma Universidade Pública Federal, e há três anos trabalhava em redes públicas de educação. Logo após terminar o curso de Pedagogia, foi aprovada em dois concursos públicos, um deles na cidade de Guarulhos e o outro na cidade de São Paulo.

Tal fator possibilitou a Júlia experiências de naturezas diferentes, pois iniciou sua carreira na rede educacional da cidade de Guarulhos e, em seguida, assumiu um cargo na prefeitura de São Paulo. E uma das dificuldades iniciais da professora Júlia foi proveniente, justamente, deste processo.

Eu tenho dificuldade com indisciplina. Porque eu venho de um contexto de salas muito calmas, em Guarulhos-SP. Eu tive a experiência com indisciplina de alunos, na prefeitura de São Paulo. Eu fiz combinados, conversei, mas aqui num contexto em que diante da indisciplina você tem professores que berram, pegam uma régua e batem na mesa. Eu lido com a indisciplina com uma perspectiva piagetiana. Na minha formação eu estudei muito Vigotsky e Marx, mas eu gosto do Piaget. Porque ele mudou a minha visão sobre indisciplina. Eu fui testando. Em situação de conflito quando os alunos brigam por causa de um lápis. Eu faço eles se colocarem no lugar do outro e tentarem resolver seus próprios conflitos, porque do contrário eles sempre vão depender do adulto e consequentemente não desenvolve a autonomia. E isso é importante (Professora Júlia). 


\section{AS ESTRATÉgIAS PARA A SUPERAÇÃO DAS DIFICULDADES: COM BASE NA FORMAÇÃO E NO HABITUS}

Diante dos desafios e dificuldades na profissão cada professor busca explorar diferentes formas de trabalho, alternativas, procedimentos que possibilitem o sucesso almejado. No caso das professoras Alice e Sofhia essa fase da exploração resultou na identificação de metodologias que pudessem auxiliar os alunos das salas de recuperação, levando-os a superarem suas dificuldades, e, portanto, desenvolvendo suas potencialidades.

Alice e Sofhia identificaram que métodos como jogos, brincadeiras, escrita de cartas, análises de contas de água e luz, e a correção coletiva realizada na lousa, resultavam positivamente. Estas ações se estabilizaram nas práticas do cotidiano de suas aulas, e, portanto, eram constantemente utilizadas pelas professoras para planejar e desenvolver suas aulas.

Nós fazíamos atividades utilizando a escrita de cartas. Vestíamos de carteiro para entregar as cartas, e as demais professoras nos olhavam com ar de reprovação, alegando que as crianças não iriam aprender nada com isso. E destacavam: "Tinha que ser iniciante". Teve professor que chegou a dizer: 'segura tua onda'. Então eu tive que entender que eu não poderia querer ser aceita pelo professor do lado. Mas, no final de tudo, elas viram que crianças que não sabiam ler e escrever, agora escreviam cartas para alguns professores. Então, quando eu comecei a trabalhar como professora eu pensei vou fazer tudo o que eu puder para ajudar esses alunos, em tudo, o que não me ajudaram eu vou fazer diferente. (Professora Sofhia).

Uma característica importante nas ações das professoras foi a ênfase em afirmar que o erro é um fator a ser superado, e não, fator limitante na aprendizagem. Tanto a professora Sofhia quanto a professora Alice identificaram a necessidade de trabalhar a autoestima dos alunos, pois se estes alunos continuassem a acreditar na sua incapacidade de aprender pouco seria possível de avançar no desenvolvimento dos mesmos.

Quando eu era aluna (ensino básico) eu fui muito excluída na escola. E quando eu via a situação daqueles alunos eu me colocava no lugar deles. Minha família era muito pobre. Viemos do Paraná. Com 4 ou 5 anos já trabalhávamos na roça. E quando viemos para São Paulo fomos morar na favela. E quando íamos para a escola sofríamos bullying porque éramos chamados de favelados. Meus irmãos desistiram da escola por isso. Tinham vergonha de morar na favela. Meu pai achava desperdício de tempo ir para escola. Ir para escola era despesa. Sendo negra, favelada, então tinha... eu tenho muito cabelo, (risos) então quando alguém pegava piolho, era meu. Mesmo eu fazendo umas traças que me deixava parecendo uma japonesa, as meninas alegavam que era de mim que elas pegavam piolho. Já tinha toda essa identidade. Quase não se tinha negros na escola em 1977. [...] Eu achava que a escola não era para mim, porque não encontrava os meus lá. Eu tinha apelido de Pelé, Kuntakinte. Eu ia apontar meu lápis e a professora falava: De novo Kuntakinte? Eu não sabia quem era. E ela falava que ia cortar meu pé. Por isso que eu me surpreendi quando me decidi por ser professora. Porque voltar para escola não seria fácil. Mas, foi bom voltar para superar isso. Eu conclui a escola por persistência, não por incentivo. A escola foi muito violenta. A minha dificuldade nunca era culpa da escola ou dos professores, a culpa era minha, da minha pobreza. Eu sempre tive que correr 
mais, me esforçar mais. Então terminar a escola foi uma vitória (Professora Sofhia).

As experiências vividas pela professora Sofhia, no que se refere à escola, foram negativas e retornar ao ambiente escolar, como professora, foi uma maneira de superar os traumas: "Eu quando aluna eu fui muito excluída na escola. E quando eu via a situação daqueles alunos eu me colocava no lugar deles. Então eu decidi que eu iria fazer por eles o que nunca fizeram por mim”.

Ambas as professoras desenvolveram um habitus de resistir a uma dinâmica de exclusão que se reproduz no âmbito escolar, e também transformaram suas experiências negativas, vividas no período em que eram alunas da escola básica, em estratégias para não permitir que seus alunos vivessem os mesmos dilemas que elas viveram.

O Aluno Caio (Nome fictício) sempre fez as atividades comigo. E a professora dele se irrita porque ele faz as atividades comigo, mas não faz com ela. Uma vez ela me falou na frente dele: '- Esse menino não faz nada comigo, só dá trabalho!' E por causa disso, ele ficou muito chateado e eu conversei com ele. Um dia eu o chamei e perguntei: 'Porque você não faz a lição com sua professora?' E ele me falou assim: 'Ah, Professora! Ela fala que eu não sei fazer, então eu não faço'. E eu respondi para ele assim: 'Caio, então vamos mostrar para ela que você pode, que você consegue fazer, para que ela tenha orgulho de você, como eu tenho?' E agora, ele faz tudo (Professora Alice).

Já a estratégia da professora Júlia foi utilizar conhecimentos construídos no PIBID (Programa Institucional de Bolsa de Iniciação à Docência) para elaborar suas metodologias e dinâmicas de aula.

Então, eu fui meio que descobrindo como fazer num percurso solitário. Eu pegava algumas experiências que tinha feito na faculdade e no PIBID e montava as atividades. Então, eu fiz PIBID de matemática, então eu tenho muito mais facilidade em matemática por isso. No PIBID eu descobri algumas coisas de rotina, de planejamento (Professora Júlia).

Nas manifestações e ações da professora Júlia fica visível a 'perspectiva formadora', ou seja, a formação obtida na graduação fez com que a professora Júlia superasse uma dificuldade com relação à disciplina de Matemática, redefinindo características da identidade da professora que passou a ter a Matemática como sua disciplina preferida a ser ensinada. Isso interferiu diretamente e positivamente nas aulas da professora, pois ao ensinar a construção de gráficos para os alunos do quarto ano a professora demonstrou total domínio do conteúdo e da metodologia no ensino da matemática.

Parte do habitus da professora Júlia sempre esteve relacionado aos estudos, à pesquisa e a uma busca constante pelo saber: "A minha relação é com o saber. Obviamente que a criança faz parte deste processo, mas a minha relação principal é com o conhecimento". 


\section{CONSIDERAÇÕES FINAIS}

Eu acho importante estudar porque se não você se encaixa no sistema e começa a pensar como todo mundo. E a tendência é começar a reproduzir falas e posturas de colegas. Então é necessário continuar estudando (Professora Júlia).

O resultado do trabalho realizado pelas professoras culminou nos seguintes aspectos: motivação dos alunos no processo de aprendizagem; interação e participação nas aulas; frequência e permanência dos alunos nas aulas; e reconhecimento por parte da gestão com relação ao trabalho realizado pelas professoras.

Programas de formação como o PIBID e residências pedagógicas foram apontados como recursos importantes na formação das professoras. Um fator importante que indica sucesso no trabalho de um professor é a própria manifestação do aluno. Durante as aulas, houve em diferentes momentos manifestações dos alunos, que afirmavam que tinham vergonha de frequentar as aulas de reforço, mas no decorrer do percurso perceberam que estava aprendendo, e a partir de então, sentiam prazer em estar nas aulas. Também nas aulas da professora Júlia, os alunos manifestaram o desejo de continuar a ter aulas com a professora, alegando gostar dela e de suas aulas.

Os resultados da pesquisa confirmaram a hipótese de que a formação no Ensino Superior é essencial para o sucesso no desenvolvimento do trabalho docente, aliado às facetas do habitus, desenvolvido pelo indivíduo em outras circunstâncias na composição de disposição da área didática a partir de saberes, contribuindo para o desempenho profissional do professor.

A Escola é uma instituição complexa, de relações sociais complexas, com problemas e dilemas provenientes da sociedade. E para trabalhar e cumprir a função de professor nesta instituição é extremamente importante uma formação que proporcione aos profissionais que ali atuam as condições de análise social, política, psicológica e didática.

O sucesso no início de carreira das professoras pesquisadas foi o resultado de uma formação consistente e de um habitus que resiste a toda e qualquer forma de exclusão e preconceitos. As professoras apresentaram a consciência de que sua função e seu trabalho são a garantia do acesso democrático ao conhecimento, o que fará toda a diferença na vida de seus alunos.

\section{REFERÊNCIAS}

BOURDIEU, Pierre. Esboço de uma Teoria da Prática. In: ORTIZ, Renato (Org.). A sociologia de Pierre Bourdieu, São Paulo: Editora Ática, 1994, n. 39, p. 46-86.

. Espaço social e espaço simbólico. In: Razões práticas: sobre a teoria da ação. Campinas, SP: Papirus, 1996. 
. É possível um ato desinteressado? In:

Razões práticas: sobre a teoria da ação. Campinas, Papirus, 1996, p.137-156.

BOURDIEU, P.; CHARTIER, R. Habitus e campo. In: O sociólogo e o historiador. Belo Horizonte: Autêntica Editora, 2012 , p. 57-68.

BOURDIEU. P. A Distinção: crítica social do julgamento. 2 ed. Porto Alegre, RS: Zouk, 2013.

GOMES, Fernanda Oliveira Costa. 2020. Professoras iniciantes e bem-sucedidas: Análise das estratégias didáticas de professores bem-sucedidas no início de carreira. Tese (Doutorado em Educação: História, Política, Sociedade). São Paulo. Pontifícia Universidade Católica de São Paulo / Programa de Estudos Pós Graduados em Educação: História, Política, Sociedade.

HUBERMAN, M. O ciclo de vida profissional dos professores. In: NÓVOA, António (Org.). Vidas de professores. Portugal: Porto Editora, 1992.

MARIANO, A. L. S. A construção do início da docência: um olhar a partir das produções da ANPED e do ENDIPE. São Paulo. Universidade Federal de São Carlos, São Carlos, 2006. (Dissertação de Mestrado).

MARIN, A.J. Redimensionamento da Didática a partir da prática de ensino. In: MARIN, A.J. (Coord.). Didática e trabalho docente. Araraquara: Junqueira \& Marin, 2005, p.57-65.

. A busca de fundamentos e do objeto da Didática - algumas anotações a respeito de estudos e pesquisas sobre o trabalho docente. In: MARIN, A.J. (Coord.). Didática e trabalho docente. Araraquara: Junqueira \& Marin,2005, p. 150- 158.

. O curso de Pedagogia em foco: fragilidades constantes e urgências da formação. In: CAVAlCANTE, M. M. D. et al. (Org.). Didática e Prática de Ensino: diálogos sobre a escola, a formação de professores e a sociedade. 1ed. Fortaleza: ENDIPE, 2014, v. 1, p. 1141- 1154. 


\section{Cristina Régia Barreto Moreira ${ }^{1}$}

\section{RESUMO}

A Psicometria é o conjunto de técnicas capaz de medir processos mentais e promover a interpretação destes. Suas principais ferramentas são a Teoria Clássica dos Testes (TCT) e a Teoria de Resposta ao Item (TRI). A avaliação educacional é um tema polêmico na ação docente, mas também nos sistemas de ensino. Assim, é evidente a importância de realização de estudos nessa área e a utilização de testes psicométricos na Educação, uma vez que a aprendizagem é um traço latente. A TCT, amplamente incorporada à avaliação educacional, apresenta várias limitações. Os avanços oriundos da TRI são uma resposta às restrições da TCT, uma vez que com a TRI torna-se possível comparar desempenho de populações que respondem a testes distintos, desde que se preservem alguns itens comuns; é também possível comparar indivíduos da mesma população que respondem a testes completamente diferentes. Consequentemente, muitas são as aplicações exequíveis com uso da TRI, inclusive em Educação.

Palavras-chave: Psicometria. TRI. Avaliação Educacional.

\section{INTRODUÇÃO}

A Psicometria é uma área da Psicologia que trata de atribuir significados às respostas de um indivíduo a uma série de tarefas ou testes, através de processos mentais. Há duas vertentes para a Psicometria: a Teoria Clássica dos Testes (TCT) e a Teoria de Resposta ao Item (TRI). Nesta última, os testes recebem tratamento criterioso, uma vez que os traços latentes são características não observáveis diretamente, tais como inteligência e ansiedade.

De fato, a TRI se apresenta como um avanço da Psicometria em relação à TCT. As vantagens da TRI sobre a TC T são importantes, por isso a TRI tem sido largamente utilizada nas avaliações educacionais em seus diferentes contextos, assim como em outros campos da atividade humana e demais ciências.

Alguns exemplos de uso dos modelos unidimensionais da TRI são os utilizados pelo Programme for International Student Assessment (PISA) e pelo exame de proficiência em língua inglesa (TOEFL). No Brasil, a partir da aplicação da TRI no Exame Nacional do Ensino Médio (ENEM), tem crescido o interesse de diversos pesquisadores e instituições no uso dessa ferramenta, principalmente em avaliações de larga escala, para averiguar com eficiência as proficiências dos respondentes.

Segundo Rabelo (2013), as limitações da TCT estão relacionadas a:

\footnotetext{
${ }^{1}$ Mestre em Matemática (UFERSA/SBM). E-mail: cristina.moreira@ifrn.edu.br
} 
[...] discriminação dos itens, fidedignidade dos testes e comparabilidade de desempenho de indivíduos que se submeteram a testes diferentes. As estatísticas clássicas são restritas a determinado momento, a determinado teste e ao grupo que respondeu à prova, dificultando o acompanhamento pedagógico ao longo dos anos. Além disso, na TCT, os parâmetros dos itens de um teste dependem diretamente da amostra de indivíduos para os quais eles foram calculados. Desse modo, a dificuldade de um item vai variar de pesquisa para pesquisa, em função da amostra de respondentes, isto é, o parâmetro é dependente dos sujeitos (RABELO, 2013, p. 45).

No entanto, apesar dessas restrições, a TRI não busca substituir a TCT, mas complementar e aprofundar os métodos de análise das respostas a testes aplicados a um número grande de respondentes. No momento, a TRI utiliza medidas da TCT para considerar os resultados do grupo de modo a qualificar os itens do teste e melhor interpretar o resultado de cada indivíduo avaliado.

Diante da importância das inúmeras aplicações da Psicometria, esta pesquisa objetiva introduzir os principais conceitos, limitações e avanços da TCT e da TRI, enfatizando as premissas dos modelos matemáticos que as sustentam e algumas aplicações na avaliação educacional.

No cenário contemporâneo, a pesquisa bibliográfica realiza-se sob a perspectiva dos trabalhos publicados por Rabelo (2013), Andrade et al.(2000), Ferreira (2009), Pasquali e Primi (2003), dentre outros.

As hipóteses são de que a Psicometria oferece um campo produtivo, ainda em pleno desenvolvimento, capaz de ampliar efetivamente o conhecimento sobre a aprendizagem educacional, assim como de outros construtos. A cada dia, com o avanço tecnológico e matemático, novos algoritmos e softwares vão resolvendo problemas de restrições dessas teorias e permitindo melhorar as estimativas de traços latentes.

\section{PSICOMETRIA: MODELOS MATEMÁTICOS}

Com o objetivo de medir traços latentes $(\theta)$, ou seja, características de indivíduos não mensuráveis diretamente, a Psicometria propõe dois modelos matemáticos: a TCT e a TRI. As referências para as medidas mudam em cada teoria: a TCT utiliza o escore do teste como um todo; e a TRI concentra-se no item, como bem diz seu nome. No entanto, ambas realizam a análise através de parâmetros estimados e apresentam uma avaliação do instrumento de medida.

\section{Teoria Clássica dos Testes}

Durante muitos anos, a TCT foi a principal ferramenta de análise estatística nas avaliações de traços latentes e, desde então até os dias atuais, é a teoria dominante em se tratando de aplicação 
na avaliação educativa. Por conseguinte, a TCT não foi suplantada pela TRI e nem deve ser abolida. Como será visto, ela é bastante útil. Além disso, ampara as teorias recentes na obtenção de análises mais qualitativas.

Ora, todo modelo matemático necessita de pressupostos que delimitam sua aplicação. Segundo Ferreira (2009) as premissas para a TCT são as abaixo descritas.

[...] No modelo clássico, dois construtos são introduzidos: o escore verdadeiro e o erro de medida. $\mathrm{O}$ escore verdadeiro para um indivíduo pode ser definido como um valor esperado dos seus escores obtidos em vários testes. $\mathrm{O}$ erro de medida pode ser definido como a diferença entre o escore verdadeiro e o observado. $\mathrm{O}$ modelo clássico supõe que: (1) os erros de medida são aleatórios com média zero e não correlacionados entre si e com os escores verdadeiros e (2) os escores verdadeiros, os observados e os erros de medida são linearmente relacionados. (FERREIRA, 2009, p. 8).

Disso resulta que o modelo matemático da TCT pode ser assim expresso (FERREIRA, 2009, p. 8):

$$
x=t+\epsilon,
$$

em que $x, t$ e $\epsilon$ são, respectivamente, o escore observado, o escore verdadeiro e o erro de medida. Ou seja, os pressupostos acima nos levam a:

1. $E(\epsilon)=0$;

2. $\rho(t, \epsilon)=0$;

3. $\rho\left(\epsilon_{1}, \epsilon_{2}\right)=0$,

em que $\epsilon_{1} e \epsilon_{2}$ são os erros de medida em duas aplicações de um teste.

\section{Limitações da TCT}

Ferreira (2009) resume as limitações teóricas graves da Psicometria Clássica em quatro pontos principais.

a) Os parâmetros clássicos dos itens (dificuldade e discriminação) dependem diretamente da amostra de sujeitos utilizada para estabelecê-los. É o que Pasquali e Primi (2003) chamam de subject-dependent, isto é, o parâmetro varia de pesquisa para pesquisa em função da amostra de sujeitos.

b) A avaliação das aptidões dos respondentes depende do teste utilizado. Nesse caso temse test-dependent, ou seja, a resposta fica ligada ao instrumento utilizado, de tal forma que o objeto medido afeta diretamente o instrumento utilizado (PASQUALI; PRIMI, 2003). 
c) A definição do conceito de fidedignidade na TCT apresenta dificuldades, uma vez que se baseia na correlação entre escores obtidos de um teste como oposto do erro de medida. O erro de medida é considerado o mesmo para todos os itens e examinados. Isso é muito improvável, pois seria admitir que indivíduos com baixa proficiência mobilizam erros iguais aos de proficiências mais altas.

d) A informação gerada do item é resultado das análises globais do teste. Não se sabe o que cada item individualmente provoca no respondente. Nota-se uma incongruência: por que analisar itens que presumidamente são assumidos como adequados? Se são ou não adequados, como saber, já que a análise é feita em função do escore total, o qual cada item influencia? O problema é avaliar a adequação de um item utilizando-o na análise e considerando que os demais estejam adequados, quando, na verdade, nada se sabe sobre isso.

Por tudo isso é que se tornou pungente o surgimento de uma nova ferramenta de avaliação psicométrica para a superação dos fatos levantados. Mas apesar desses problemas serem conhecidos desde os anos 1930, a sua solução só ocorreu de forma efetiva nos anos 1980. A demora está relacionada à complexidade dos algoritmos matemáticos propostos pela TRI para obter a independência do instrumento de medida em relação ao objeto de medida.

A aplicação de tais algoritmos foi viabilizada somente após o avanço computacional e a disponibilidade de softwares específicos, sendo o primeiro deles o BICAL em 1979, seguidos pelo LOGIST e pelo BILOG em 1984 (PASQUALI; PRIMI, 2003).

\section{Avanços com a Teoria de Resposta ao Item}

Também conhecida como Teoria do Traço Latente, a TRI fundamenta-se na relação entre variáveis observáveis e variáveis hipotéticas para, fixando as aptidões, estimar os parâmetros dos itens respondidos pelos indivíduos.

Desse modo, são introduzidos dois postulados na nova teoria: (1) o traço latente $\theta$ é a causa e o desempenho do sujeito no item do teste. É o efeito, ou seja, comportamento é função de $\theta$; (2) a relação entre desempenho e traço latente ou aptidão de um indivíduo pode ser descrita por uma equação matemática monotônica crescente, isto é, à medida que $\theta$ aumenta, também aumenta a probabilidade de acerto ao item (PASQUALI; PRIMI, 2003).

Deve-se enfatizar que a TRI substitui a TCT em parte, principalmente a que se refere à análise dos itens do teste. Os avanços oriundos da TRI são uma resposta às restrições da Teoria Clássica. Pasquali e Primi (2003) dividem estas vantagens em cinco avanços. 
[...] a) o cálculo do nível de aptidão do sujeito independe da amostra de itens utilizados: diz-se que a habilidade do sujeito é independente do teste (not testdependent). [...];

b) o cálculo dos parâmetros dos itens (dificuldade e discriminação) independe da amostra de sujeitos utilizada: diz-se que os parâmetros são independentes dos sujeitos (not group-dependent). [...];

c) a TRI permite emparelhar itens com a aptidão do sujeito. Isto quer dizer que se avalia a aptidão de um sujeito, utilizando itens com dificuldade tal que se situam em torno do tamanho da aptidão do sujeito, sendo, assim, possível utilizar itens mais fáceis para sujeitos com habilidades inferiores e itens mais difíceis para sujeitos mais aptos, produzindo escores comparáveis em ambos os casos. [...];

d) a TRI constitui um modelo que não precisa fazer suposições que aparentam ser improváveis, tais como os erros de medida serem iguais para todos os testandos; e) a TRI não necessita trabalhar com testes estritamente paralelos como exige a psicometria clássica (PASQUALI; PRIMI, 2003, p.102-103).

Assim, torna-se possível comparar desempenho de populações que respondem a testes distintos, desde que se preservem alguns itens comuns ou, ainda, comparar indivíduos da mesma população que respondem a testes completamente diferentes. Isso amplia as aplicações da TRI porque possibilita a comparação longitudinal de populações.

Por outro lado, existem dois pré-requisitos postulados para a TRI: a unidimensionalidade e a independência local. Sobre a unidimensionalidade sabe-se, desde os anos 1930, que todo desempenho humano na execução de determinadas tarefas exige um conjunto de traços latentes, chamados de $n$ dimensões (PASQUALI; PRIMI, 2003). Assim, o comportamento pode ser expresso como vetor de vários tetas. Isso ocorre simplesmente porque é evidente que todo comportamento humano é multideterminado, ou seja, as motivações são sempre variadas e simultâneas. No entanto, para a TRI a suposição é de que há uma única aptidão dominante responsável pelo desempenho no teste.

Agora, sobre a independência local supõe-se que mantidas constantes as aptidões que afetam o teste, menos o teta dominante, as respostas dos sujeitos a quaisquer dois itens são estatisticamente independentes (PASQUALI; PRIMI, 2003). A importância desse postulado é assumir que o desempenho no teste como o todo é o produto das probabilidades de acerto a cada item individualmente. Não significa que os itens não possam estar correlacionados, mas que um não interfere na probabilidade de acerto ao outro.

O que se deseja com essas suposições é apresentar um modelo matemático capaz de estimar a aptidão de um indivíduo realizando análises das respostas dadas por ele a uma série de itens. Isto é, a TRI fornece a probabilidade que um determinado sujeito tem de acertar a um item específico, conhecidos seus parâmetros e a proficiência dos respondentes.

Assim, quando um indivíduo responde um conjunto de itens, este produz um padrão de respostas com uma sequência de 1 (quando acerta) e 0 (quando erra). A partir dessas respostas é 
gerada uma matriz formada pelo número de linhas igual ao número de respondentes e pelo número de colunas igual à quantidade de itens no teste. Essa tabela é conhecida como matriz de padrão de resposta dos indivíduos. Em avaliações de larga escala, como, por exemplo, o ENEM, essas matrizes são gigantescas, com milhões de linhas e muitas colunas. Esse é mais um motivo, além da complexidade dos algoritmos dos modelos da TRI, para a necessidade de recursos computacionais poderosos na manipulação desses dados.

\section{TRI: breve retrospectiva histórica}

A TRI teve início na década de 50 com modelos que consideravam somente uma aptidão em um único grupo e com respostas dicotômicas sim ou não, zero ou um. Mais precisamente foi a partir dos trabalhos de Lord, em 1952, que a TRI toma corpo através do primeiro modelo unidimensional de dois parâmetros. Concomitante e independentemente, em 1960, Rasch apresenta o modelo unidimensional de um parâmetro, descrito, em seguida, como modelo logístico por Wright. Após algumas aplicações, Lord responde a necessidade de incluir um terceiro parâmetro que considerasse o problema do acerto casual, surgindo o modelo de três parâmetros (ANDRADE et al, 2000).

Em 1968, Birnbaum propõe a substituição da função ogiva normal pela função logística, matematicamente mais adequada por não envolver integração e explicitar os parâmetros do item e a habilidade. O modelo de resposta gradual foi introduzido por Samejima em 1969. No entanto, os modelos de mais de duas categorias de respostas só foram implementados em 1972 por Bock, em 1978 por Andrich, em 1982 por Masters e em 1992 por Muraki (ANDRADE et al, 2000).

A partir de 1997, Bock e Zimowski introduziram os modelos logísticos de 1, 2 e 3 parâmetros para duas populações de respondentes, portanto, bem recentemente. O método da máxima verossimilhança marginal foi proposto por Bock e Zimowski, em 1970, para solucionar problemas de estimação simultânea de parâmetros e aptidões. Em 1981, Bock e Aitkin modificam esse método introduzindo o algoritmo EM de Dempster, Laird e Rubin (ANDRADE et al, 2000).

Já os métodos Bayesianos foram pensados para resolver problemas relacionados à estimação dos parâmetros dos itens respondidos corretamente ou incorretamente por todos os indivíduos e, ainda, os relacionados com a estimação das proficiências de indivíduos que acertaram ou que erraram todos os itens do teste.

\section{MODELO LOGÍSTICO DE TRÊS PARÂMETROS}

A função logística tem substituído o modelo da ogiva normal, em parte devido à simplificação do algoritmo, dado que não se usam integrais, além de apresentar melhor ajuste dos 
dados. A preferência também se explica por que o método da máxima verossimilhança é matematicamente mais fácil de produzir do que as dos mínimos quadrados (PASQUALI; PRIMI, 2003).

A função logística aplicada a TRI é expressa da seguinte forma (PASQUALI; PRIMI, 2003, p. 106):

$$
p(\theta)=\frac{1}{1+e^{-a(\theta-b)}}
$$

em que

- $e$ é a constante de Euler, equivalente a 2,7182818...;

- $b$ é o parâmetro de dificuldade do item;

- $a$ é a discriminação do item;

- $\theta$ é a aptidão, traço latente, do indivíduo;

- $a(\theta-b)$ é o desvio logístico também chamado de logit.

Por outro lado, um modelo muito utilizado na TRI, inclusive pelo SAEB e o ENEM, é o logístico de três parâmetros (ML3 ou 3LP) que considera a dificuldade $(b)$, a discriminação $(a)$ e a probabilidade de acerto ao acaso $(c)$ do item. O favoritismo do modelo ML3 está relacionado ao melhor ajuste desse modelo a itens politômicos com uma única opção correta que, em vista disso, podem ser dicotomizados nas categorias certo (1) ou errado (0).

Ora, o ML3 modela a probabilidade de um sujeito $j$ de aptidão $\theta$ acertar um item $i$, cujas características são os parâmetros $a, b$ e $c$, ou seja, discriminação, dificuldade e acerto casual, respectivamente.

Veja essa função expressa conforme Andrade et al. (2000, p. 9):

$$
P\left(U_{i j}=1 \mid \theta_{j}\right)=c_{i}+\left(1-c_{i}\right) \frac{1}{1+e^{-D a_{i}\left(\theta_{j}-b_{i}\right)}}
$$

com $i=1,2, \ldots, I$ e $j=1,2, \ldots, n$, em que:

$U_{i j}$ é uma variável dicotômica que assume os valores 1 , quando o indivíduo $j$ responde corretamente o item $i$, ou 0 quando o indivíduo $j$ não responde corretamente ao item $i$;

$\theta_{j}$ representa a habilidade (traço latente) do j-ésimo indivíduo;

$P\left(U_{i j}=1 \mid \theta_{j}\right)$ é a probabilidade de um indivíduo $j$ com habilidade $\theta_{j}$ responder corretamente o item $i$ e é chamada de Função de Resposta do Item - FRI; 
$b_{i}$ é o parâmetro de dificuldade (ou de posição) do item $i$, medido na mesma escala da habilidade;

$a_{i}$ é o parâmetro de discriminação (ou de inclinação) do item $i$, com valor proporcional à inclinação da Curva Característica do Item - CCI no ponto $b_{i}$

$c_{i}$ é o parâmetro do item que representa a probabilidade de indivíduos com baixa habilidade responderem corretamente o item $i$ (muitas vezes referido como a probabilidade de acerto casual);

$D$ é um fator de escala, constante e igual a 1. Utiliza-se o valor 1,7 quando se deseja que a função logística forneça resultados semelhantes ao da função ogiva normal (ANDRADE et al, 2000, p. 9-10).

Esse modelo prevê que sujeitos com maior habilidade têm maior probabilidade de acertar o item e que esta não é uma relação linear. Para melhor compreensão dos elementos envolvidos nesse algoritmo e sua interpretação sugere-se a leitura de Rabelo (2013).

\title{
APLICAÇÕES NA EDUCAÇÃo
}

Pode-se dizer que a TRI está "em moda", visto beneficiar pesquisas em todos os campos do conhecimento, incluindo no desenvolvimento de modelos próprios para testar desempenhos e reduzir a complexidade de seus métodos.

Na educação, a TRI tem sido frequentemente utilizada.

\begin{abstract}
Alguns exemplos de avaliações em larga escala que utilizam a TRI são o teste TOEFL (Test of English as a Foreign Language) e o teste GRE (Graduate Record Examination), aplicados via testagem adaptativa por computador (computerized adaptative testing - CAT) pelo Educational Testing Service - ETS (ANDRADE et al., 2010, p. 423).
\end{abstract}

Nesse contexto, influenciado por pesquisas em Psicometria e sistemas de avaliação em larga escala internacionais, o Instituto Nacional de Estudos e Pesquisas Educacionais Anísio Teixeira (INEP) implanta, a partir de 1995, as técnicas da Teoria de Resposta ao Item reestruturando o Sistema de Avaliação da Educação Básica (SAEB) que, desde 1990, levantava dados sobre o ensino brasileiro, mas que não permitia a comparabilidade desses dados ao longo dos anos.

O pioneirismo do SAEB e a implementação da Prova Brasil, com o uso da TRI, possibilitou a construção de uma série histórica do desempenho dos estudantes em todas as regiões do país. A partir de então, outras avaliações nacionais, tais como o Exame Nacional para Certificação de Competência de Jovens e Adultos (ENCCEJA) e o Exame Nacional do Ensino Médio (ENEM) passaram a utilizar a TRI. 
Em se tratando de ENEM, sua adesão a TRI ocorre em 2009, depois de decorridos 11 anos de sua implementação. Segundo Rabelo (2013),

[...] isso permitirá o acompanhamento longitudinal do desempenho nas quatro áreas avaliadas, constituindo excelente indicador para a implantação de políticas públicas de melhoria da qualidade de ensino na educação básica (RABELO, 2013, p. 50).

Portanto, é possível, a partir dessas estimativas, realizar a interpretação da escala de proficiência, gerando relatórios para as escolas com intuito de orientar a ação pedagógica das mesmas e a implantação de políticas públicas pertinentes.

No entanto, deve-se lembrar de que dados educacionais dificilmente podem ser considerados unidimensionais. Por isso, espera-se que nos próximos anos modelos como os de Hambleton e McDonald sejam aplicados fortemente, uma vez que dados politômicos e multidimensionais têm maior ocorrência no âmbito educacional (ANDRIOLA, 2009).

\section{LIMITAÇÕES DA TRI}

Apesar de pouco tempo, o desenvolvimento da TRI é notável. No entanto, ainda será necessário superar algumas limitações dessa teoria. Para isso, o principal cuidado diz respeito ao ajuste dos modelos para a obtenção de itens e habilidades invariantes, ou seja, a escolha de modelos e pressupostos adequados que garantam a validade e comparabilidade dos resultados. (ANDRADE et al., 2010).

Além disso, como o objetivo é descobrir um teste que seja a representação legítima do construto, isso exige uma estreita relação entre a Psicometria e a Psicologia Cognitiva, ou seja, a confiabilidade do construto de um teste pode ser vista de diferentes ângulos: análise da representação comportamental do construto, análise por hipótese, a curva de informação do item. (PASQUALI, 2009).

Andrade et al. (2000) traz um resumo das vantagens e desvantagens dos métodos da máxima verossimilhança marginal (MVM) e Bayesiano, tanto para a estimação dos parâmetros dos itens, quanto à estimação das habilidades. Segundo esse autor, as limitações da MVM relacionadas à estimação dos parâmetros dos itens são:

(1) não está definido para itens com acerto total ou erro total;

(2) é bastante trabalhoso computacionalmente;

(3) necessidade do estabelecimento de uma distribuição para a média populacional; 
(4) apresenta problemas na estimação do parâmetro de acerto casual em alguns casos;

(5) deve ser usado somente com um número suficientemente grande de respondentes. (ANDRADE et al., 2000, p. 76).

Para a estimação das habilidades, o MVM não está definido para alguns padrões de respostas.

Já o método Bayesiano para estimação dos parâmetros dos itens apresenta as seguintes restrições: dar mais trabalho computacionalmente que o MVM e necessita de distribuições a priori para os parâmetros dos itens (ANDRADE et al., 2000).

Por fim, o método Bayesiano para a estimação das habilidades tem a desvantagem de: produzir estimadores viciados; exigir cálculos mais complexos que o MVM e necessitar de uma distribuição a priori para $\theta$.

\section{CONSIDERAÇÕES FINAIS}

A Psicometria Clássica na abordagem de avaliações psicológicas e educacionais apresenta como principais limitações: a dependência entre os parâmetros dos itens do teste e a amostra de respondentes; a dependência entre o teste como um todo e a aptidão dos sujeitos examinados; a fidedignidade da teoria, uma vez que assume a premissa de que o erro de medida é o mesmo para todos os respondentes.

Nesse contexto, surge a Psicometria Moderna para suplantar as limitações da TCT. Atualmente, existem vários modelos matemáticos para a TRI que se diferenciam quanto à função e à quantidade de parâmetros, o número de dimensões estudadas (unidimensionais ou multidimensionais), para traço latente cumulativo ou não cumulativo, quanto ao tipo de item (dicotômico ou politômico) e quanto ao número de populações envolvidas.

Os modelos de estimação de parâmetros dos itens e de estimação das habilidades propostos dessa nova teoria trouxeram os seguintes avanços: a medida da proficiência do sujeito independe do teste; os parâmetros dos itens são independentes dos respondentes; possibilita emparelhar itens em torno da aptidão dos examinados; supõe que a probabilidade de acerto não é a mesma para todos os sujeitos, portanto, indivíduos com maior proficiência têm maiores chances de acerto. Assim, a TRI fornece a probabilidade que um determinado sujeito tem de acertar a um item específico, conhecidos seus parâmetros e a proficiência dos respondentes.

Em vista disso, torna-se possível comparar avaliações de populações ao longo do tempo e aplicar testes distintos para os examinados, uma vez que os itens são invariantes e não interferem 
na aptidão medida. Como a aprendizagem ou cognição é um traço latente, muitos são os exemplos de uso da TRI na educação no Brasil e no mundo.

Apesar desses avanços, os modelos da TRI precisam superar algumas restrições. As principais delas são: a complexidade computacional; estimação de acertos totais e erros totais no teste; estabelecimento de distribuição a priori para média, parâmetros dos itens ou para o traço latente; problemas de estimação de alguns acertos casuais; e aplicação apenas a um grande número de respondentes.

Como recomendação para pesquisas futuras, a partir dos estudos aqui revelados, sugerimos investigar: os modelos matemáticos de estimação dos parâmetros dos itens e das habilidades pela TRI; os recursos computacionais e sua evolução; a aplicação da TRI na educação; a engenharia de elaboração de itens; e a construção e interpretação das escalas de proficiência.

\section{REFERÊNCIAS}

ANDRADE, D. F.; TAVARES, H. R; VALLE, R. C. Introdução à teoria da resposta ao ítem: conceitos e aplicações. In: SIMPÓSIO NACIONAL DE PROBABILIDADE E ESTATÍSTICA, 14, Caxambu, MG, 2000. Disponível em: http://www.ufpa.br/heliton/arquivos/LivroTRI.pdf. Acesso em: 16/02/2020.

ANDRADE, J. M.; LAROS, J. A; GOUVEIA, V. V. O uso da Teoria de Resposta ao Item em avaliações educacionais: diretrizes para pesquisadores. Avaliação Psicológica [online]. Revista da Universidade São Francisco, São Paulo, v. 9, n. 3, p. 421-435. 2010. Disponível em: http://pepsic.bvsalud.org/scielo.php?script=sci_arttext\&pid=S1677-04712010000300009.

Acesso em: 10/02/2020.

ANDRIOLA, W. B. Psicometria Moderna: características e tendências. Estudos em Avaliação Educacional. Periódico da Fundação Carlos Chagas - FCC, São Paulo, v.20, n. 43, maio/ago., p. 319-340. 2009. Disponível em: www.fcc.org.br/pesquisa/publicacoes/eae/arquivos/1496/1496.pdf. Acesso em: 10/01/2020.

FERREIRA, F. F. G. Escala de Proficiência para o ENEM: utilizando teoria da resposta ao item.105 p. 2009. Dissertação (Mestrado Programa de Pós-graduação em Matemática e Estatística) - UFPA, Belém, PA, 2009. Disponível em: http://www.ppgme.ufpa.br/doc/diss/fialhoguedes.pdf. Acesso em: 04/03/2019.

PASQUALI, L. Psicometria. Revista da Escola de Enfermagem da USP, n. 43, p. 992-999, 2009. Disponível em: http://www.scielo.br/scielo.php?pid=S008062342009000500002\&script=sci_arttext. Acesso em: 17/02/2020.

PASQUALI, L.; PRIMI, R. Fundamentos da teoria da resposta ao item: TRI. Avaliação Psicológica, v. 2, n. 2, p. $99 \quad$ - 110 , 2003. Disponível em: http://pepsic.bvsalud.org/scielo.php?script=sci_arttext\&pid=S1677-

04712003000200002\&lng=pt\&nrm=iso. Acesso em: 06/04/2019. 
RABELO, Mauro. Avaliação educacional: fundamentos, metodologia e aplicações no contexto brasileiro. Rio de Janeiro: SBM, 2013. 258 p. 


\title{
RECURSOS DIDÁTICOS: CONCEITO E IMPLICAÇÕES PEDAGÓGICAS NO PROCESSO DE ENSINO- APRENDIZAGEM
}

\author{
Tuesla Bezerra Santos ${ }^{1}$ \\ Karina de Oliveira Lima ${ }^{2}$ \\ Kleber Kroll de Azevedo Silva ${ }^{3}$
}

\begin{abstract}
RESUMO
O presente tem como objetivo averiguar, numa perspectiva comparativa, o uso de diferentes recursos didáticos e os impactos no processo de ensino-aprendizagem em uma turma do ensino médio integrado do Instituto Federal de Educação, Ciência e Tecnologia-IFRN, Campus Ipanguaçu, na disciplina de Matemática. A pesquisa se caracteriza como um estudo exploratório de natureza qualitativa, no qual a construção dos dados ocorreu por meio da aplicação de questionários direcionados aos alunos, de entrevistas semiestruturadas junto à professora titular e de observações in loco. Desse modo, observa-se que as aplicações dos diferentes recursos didáticos, tanto os convencionais quanto os que adotam as novas tecnologias, tiveram avaliações similares, possuem benefícios e dificuldades característicos e permitem múltiplas possibilidades no processo de ensino-aprendizagem. Assim, pode-se concluir que a utilização de diferentes recursos de forma adequada pelo professor pode trazer melhorias do ensino e da aprendizagem.
\end{abstract}

Palavras-chave: Metodologia de Ensino. Recursos Didáticos. Ensino Híbrido.

\section{INTRODUÇÃO}

Tratar sobre metodologias e recursos didáticos requer uma contextualização desses elementos, que constituem a prática educativa escolar, articulada às concepções de conhecimento, desenvolvimento e aprendizagem que as engendram, pois, abordar a técnica desarticulada das dimensões do ensino, é assumir o risco de cair em mero formalismo, repetição e reprodução acrítica do fazer docente (VEIGA, 2012). Assim, antes de adentramos, especificamente, no tema desse capítulo, apresentaremos nossas concepções sobre conhecimento, desenvolvimento e ensino-aprendizagem escolar.

Adotamos as concepções de conhecimento, desenvolvimento e aprendizagem escolar ancoradas na abordagem sócio-histórica, a qual tem como precursores um grupo de estudiosos russos liderados por Lev Semyonovich Vygotsky.

\footnotetext{
${ }^{1}$ Licenciada em Informática pelo Instituto Federal de Educação, Ciência e Tecnologia do Rio Grande do Norte. Email: tuesla.santos12@gmail.com

2 Mestra e Doutoranda em Educação pela Universidade Federal do Rio Grande do Norte. E-mail: karina.lima@ifrn.edu.br

3 Mestre em Ciência da Computação pela Universidade do Estado do Rio Grande do Norte. E-mail: kleber.kroll@ifrn.edu.br
} 
Originariamente, a palavra "aprender" vem do latim aprehendere e significa agarrar, pegar, apoderar-se de algo. Ao longo do tempo, esse conceito foi ampliado, ora dando enfoque ao papel do professor, entendido como transmissor do conhecimento, ora como facilitador do processo de ensino-aprendizagem e o aluno seria o sujeito ativo desse processo. Com os estudos de Vygotsky e colaboradores (1994), compreende-se que o aluno não é apenas passivo nem ativo; ele é interativo. Essa mudança epistemológica sobre o aprender, ensinar e o conhecimento traz implicações para a educação escolar. Nisso, a condução do processo, a definição e operacionalização das situações de ensino-aprendizagens são variáveis determinantes para os processos de ensinar e aprender.

Vygotsky atribui às situações de aprendizagem, principalmente, as situações de mediação, que promovem a aprendizagem, elemento fundamental para o desenvolvimento humano e adverte que nem toda situação de ensino promove a aprendizagem. Nesse sentido, acrescentamos que a utilização de determinados recursos, por si só, não garante a aprendizagem. Refletir sobre as variáveis que constituem a adequação dos usos dos recursos é necessário, principalmente, no atual contexto educacional permeado por uma multiplicidade de recursos disponibilizados aos professores.

Assim, é de suma importância que o professor mobilize saberes da ciência da educação e que as tomadas de decisões acerca das escolhas metodológicas tenham como elementos basilares os conhecimentos subjacentes ao métier docente.

De acordo com Libâneo (2015), fazem parte da metodologia a articulação com os objetivos e conteúdo de ensino e a utilização de instrumentos e materiais didáticos. Assim, esses elementos são determinantes na metodologia a ser adotada pelo docente.

Para Veiga (2012, p.8):

As técnicas de ensino têm um caráter instrumental e intermedeiam as relações entre professor e aluno, e entre aluno e aluno. Isso significa afirmar que as são mediações, ou condições necessárias e favoráveis, mas não suficientes do processo didático.

$\mathrm{Na}$ atualidade, as transformações e evoluções dos materiais e instrumentos tecnológicos têm mudado as perspectivas metodológicas convencionais, tanto o ensino presencial quanto o ensino a distância $(\mathrm{EaD})$.

Nesta perspectiva, privilegiamos como objeto de estudo o uso de recursos didáticos e definimos como objetivo da pesquisa averiguar, numa perspectiva comparativa, o uso de 
diferentes recursos de ensino e análise comparativa das perspectivas dos alunos de uma turma do ensino médio integrado do IFRN, Campus Ipanguaçu, na disciplina de Matemática.

Para a construção deste trabalho foi realizado um estudo experimental como estratégia de investigação, no qual foram utilizadas como técnicas metodológicas: aplicação de questionários para a construção dos dados da pesquisa, por meio do público participante (professora e alunos), e observações e estudo, que construíram os elementos primordiais na elaboração dos pressupostos que deram rumo à construção da metodologia da pesquisa.

\section{CAMINHOS PERCORRIDOS: CONSTRUINDO A METODOLOGIA DE PESQUISA}

A pesquisa foi realizada junto a uma professora titular da disciplina de Matemática e os seus alunos das turmas dos $2^{\circ}$ anos, vespertino, do Curso Técnico Integrado em Informática do Instituto Federal de Educação, Ciência e Tecnologia do Rio Grande do Norte (IFRN) - Campus Ipanguaçu, Rio Grande do Norte, Brasil, no segundo semestre de 2017.

Para a elaboração deste estudo foi utilizado como método de pesquisa o estudo exploratório baseado na abordagem qualitativa em educação. Sobre esse tipo de pesquisa, Gil apud Gerhardt e Silveira (2009, p. 35) afirmam: "Este tipo de pesquisa tem como objetivo proporcionar maior familiaridade com o problema, com vistas a torná-lo mais explícito ou a construir hipóteses".

Como instrumento para a construção dos dados da pesquisa, aplicou-se um questionário com questões abertas e fechadas junto a 52 alunos matriculados nas turmas mencionadas, e estes foram perguntados sobre a percepção que tiveram diante dos diferentes recursos didáticos (quadro/lousa, apresentação eletrônica, videoaulas e software educativo) no processo de ensinoaprendizagem de Matemática em um curso do ensino médio. Os questionários foram aplicados ao final das aulas em que o docente havia adotado um dos recursos didáticos citados. O questionário, segundo Gil (1999, p.128), pode ser definido:

[...] como a técnica de investigação composta por um número mais ou menos elevado de questões apresentadas por escrito às pessoas, tendo por objetivo o conhecimento de opiniões, crenças, sentimentos, interesses, expectativas, situações vivenciadas etc.

Adotou-se também o método de entrevistas semiestruturadas realizadas com a docente titular da disciplina de Matemática da turma observada, que tiveram como foco central a obtenção de informações que compuseram a construção dos dados referentes à utilização, vantagens e desvantagens sobre o uso de cada recurso didático utilizado pela docente. Essas entrevistas foram realizadas de duas em duas, sendo a primeira sobre quadro/lousa e videoaula, e a segunda sobre 
apresentação eletrônica e software educativo. Segundo Ketele e Roegies (1996 apud Morgado 2012, p.72), a entrevista é um:

[...] método de recolha de informação que consiste em conversas orais, individuais ou em grupo, com várias pessoas selecionadas cuidadosamente, a fim de obter informações sobre factos ou representações, cujo grau de pertinência, validade e fiabilidade é analisado na perspectiva dos objetivos de recolha de informação.

$\mathrm{Na}$ pesquisa, a técnica de observação traz ao pesquisador elementos próprios de determinado conjunto de pessoas, objetivando identificar o modo de se relacionar entre si de acordo com certa circunstância. Partindo dessa ideia, Gerhardt e Silveira (2009, p. 74) definem a observação como:

Uma técnica que faz uso dos sentidos para a apreensão de determinados aspectos da realidade. Ela consiste em ver, ouvir e examinar os fatos, os fenômenos que se pretende investigar. A técnica da observação desempenha importante papel no contexto da descoberta e obriga o investigador a ter um contato mais próximo com o objeto de estudo.

Os dados construídos por meio das observações compuseram, juntamente aos dados referentes aos questionários que foram aplicados aos alunos e as entrevistas com a docente, os resultados dessa pesquisa.

\section{OS RECURSOS DIDÁTICOS UTILIZADOS NO PROCESSO DE ENSINO- APRENDIZAGEM}

O que usualmente denominamos como recursos didáticos são os materiais mobilizados pelo fazer docente para mediar e garantir as melhores condições para operacionalizar a prática docente, ou seja, constituem tecnologias educacionais. O conceito de tecnologia educacional possui duas dimensões distintas em relação à função que possui na construção dos conhecimentos, podendo assim, ser definida por Fidalgo \& Machado (2000, p. 20) como:

[...] aplicação sistemática de conhecimentos científicos e tecnológicos à solução de problemas educacionais ou como teorias e estudos específicos sobre o desenvolvimento e emprego de ferramentas, máquinas e procedimentos técnicos, em geral, em educação.

A união entre métodos, técnicas e recursos didáticos compõem as tecnologias educativas. Isso traz para a tecnologia educacional a perspectiva de ser fundamentada como parte de um corpo de conhecimentos tecnológicos e científicos, com foco no processo de ensino-aprendizagem. 
A origem da tecnologia educacional estaria, segundo Pfromm Neto (1976), nas ciências do comportamento, principalmente na Psicologia, e nas ciências físicas e nas tecnologias associadas (física, química, engenharia elétrica etc.). Outro ponto de vista apresentado por Pfromm Neto (1976) é que a origem da tecnologia da educação está ligada aos recursos tecnológicos dedicados ao campo educativo, como também à instrução programada e as máquinas de ensinar. Para isso, o autor diz que:

\begin{abstract}
A essas duas facetas originais da tecnologia da educação devem ser acrescentadas outras [...]. Referimo-nos à análise de sistemas, à cibernética, à teoria e pesquisa em comunicação e a teoria e pesquisa em psicologia da aprendizagem (PFROMM NETO, 1976, p. 5).
\end{abstract}

Os instrumentos tecno-educativos estão na posição de auxiliares e complementadores, devotados ao bom andamento dos processos que envolvem a construção dos conhecimentos, como meios pelos quais alunos e professores se comunicam e/ou por meio do que se é adequado utilizarem-vos como ferramenta mediadora na ação didática.

Os tópicos a seguir apresentam as tecnologias utilizadas no estudo exploratório deste trabalho.

\title{
O QUADRO
}

Diante de tantas tecnologias voltadas ao ensino, a que foi mais utilizada e ainda é utilizada até hoje (em menor número) é o quadro-negro, quadro-de-giz ou simplesmente quadro que possui o significado de quadrado. Essa definição possui datação em língua portuguesa registrada a partir do ano de 1612.

\footnotetext{
Superfície lisa, plana ou ligeiramente côncava, feita de madeira ou ardósia, geralmente pintada de negro ou verde, muito usado nas escolas para sobre ela escrever-se a giz; quadro-de-giz, quadro-negro[...] (HOUAISS, 2001, 2344).
}

O quadro-negro e/ou o quadro-branco representam o objeto central em sala de aula, para o qual todos os alunos devem manter suas atenções voltadas, paralelo ao lado onde o professor se encontra e propõe aos alunos os ensinamentos. Essa distribuição ou organização, embora possa aparentar certa superioridade do professor e dos conteúdos em relação aos alunos, por outro lado, como apontado por Araújo (2006), promove a interação entre o professor e os alunos e triunfa com a generalização do ensino simultâneo. 
Essas tecnologias convencionais que privilegiam o uso da escrita manual são ainda muito utilizadas, tanto que é difícil pensar em uma sala de aula que não possua uma delas, tornaram-se, assim, uma tecnologia característica do ambiente de ensino.

\section{APRESENTAÇÃO ELETRÔNICA}

Uma apresentação eletrônica é um recurso de sociabilização para exposição de temas diversos e mediação de informações em contextos diversos, com múltiplas finalidades, tais como: reuniões, seminários, palestras, aulas, entre outros. Nesse contexto, Ramos, Arriada e Fiorentini (2009) escrevem que:

\footnotetext{
As apresentações de slides ocupam lugar de destaque no contexto das escolas, em geral. Uma nova textualidade muito peculiar está associada a este tipo de documento digital. Além do uso de integrado de textos, voz, música e imagens, temos também a possibilidade da animação e da leitura não linear. Todas estas características de uma produção hipermidiática são conseguidas através de uma ferramenta de edição bastante amigável (RAMOS; ARRIADA; FIORENTINI, 2009, p. 90).
}

A estrutura de uma apresentação eletrônica é composta por várias telas em formato de ficha (slides), que são exibidas sequencialmente com o auxílio de um computador. A exibição das apresentações eletrônicas, comumente, é realizada por meio de dispositivos de projeção (datashow, retroprojetor, epidiascópio, entre outros), em que a imagem real de um objeto é ampliada e projetada sobre uma tela.

Essas outras tecnologias possuem usualidade, interatividade e diversidade quanto à exibição de por meio de recursos multimídia (de imagem, som, vídeos etc.), simulação de imagem (gráficos 3D, emuladores de processos etc.) e acesso livre à navegação na Web.

\section{A VIDEOAULA}

As primeiras câmeras surgiram no mercado no ano de 1965, mas, somente a partir da década de 1980, essa mídia explodiu em quesitos de popularidade com o surgimento dos aparelhos de videocassete (VHS), e, na década de 1990, com os aparelhos com tecnologia de discos ópticos (DVD), até os anos 2000 com a popularização da internet as multimídias, principalmente o vídeo, o que vem se tornando cada vez mais presente no ensino e na aprendizagem. 
Todo o percurso histórico das videoaulas está diretamente ligado ao desenvolvimento dos recursos e metodologias adotadas no ensino a distância. Os autores Candeias e Carvalho (2016, p. 8) indicam que:

O uso dessas aulas em vídeo contempla os alunos com diferentes percepções do conteúdo, onde estas aulas são apresentadas de forma multissensorial, pois utiliza-se de vídeo, áudio e imagens, fazendo com que o aluno tenha um interesse maior pelo conteúdo, incentivando-o a pesquisar mais sobre o assunto. Dessa forma, o aluno irá sentir-se mais estimulado em aprender, diferente das aulas tradicionais que se norteiam apenas pela linguagem escrita e falada.

A videoaula possui uma estruturação peculiar divergente dos demais recursos: a possibilidade de acessar essas videoaulas e complementar, resgatar ou até construir os conhecimentos necessários a partir de aulas gravadas.

\section{SOFTWARE EDUCATIVO}

No âmbito educacional, o software se tornou o mais importante elemento para que o computador fosse inserido no processo de ensino-aprendizagem como tecnologia educativa (JUCÁ, 2006, p. 23).

Com a utilização desse recurso, os alunos têm a autonomia quanto à manipulação do meio de acesso, que, no caso do software, é o computador. Outras alternativas para inserir os softwares educativos nas salas de aula têm sido utilizadas, como a citada por Gouvêa e Pereira (2015, p. 42), quando dizem que:

Precisamos buscar meios que proporcionem o seu acesso a todas as pessoas, inclusive o celular entre os alunos de forma educativa, já que este é um meio de comunicação de mais fácil acesso e que seus aplicativos podem contribuir para aprimorar os conhecimentos já existentes.

Nesse contexto, a aprendizagem móvel se mostra promissora, já que de acordo com dados divulgados pela Agência Nacional de Telecomunicações (Anatel), a telefonia móvel registrou 240.850.681 linhas em operação em outubro de 2017. O uso do celular, principalmente pelos jovens, é uma realidade muito atual no meio educacional e também pelo motivo de que este é um dos avanços que faz parte da vida da maioria da população e dos jovens alunos. 


\section{ENSINO HÍBRIDO}

O blended learning, em livre tradução "aprendizado mesclado", ou como ficou definido em língua portuguesa pelo termo “Ensino Híbrido”. Segundo Christesen, Horn e Staker (2015), “[...] é uma combinação da nova tecnologia disruptiva com a antiga tecnologia, e representa uma inovação sustentada em relação à tecnologia anterior". Esse modelo de ensino é denominado assim por integrar o ensino presencial ao ensino virtual, na escola e fora dela.

No ensino híbrido, o objetivo é estimular a autonomia dos alunos para que eles consigam desenvolver uma consciência de trabalho grupal e compartilharem seus novos conhecimentos adquiridos. De acordo com Bacich e Tanzi Neto (2015, p. 3):

[...]esses espaços se tornam complexos sistemas de interações entre alunoconhecimento, aluno-professor, aluno-aluno, no qual a distribuição do conhecimento não se dá apenas pelo professor, mas por todos os seus participantes com a ajuda de diferentes ferramentas digitais. Sendo assim, o Ensino Híbrido parte de uma proposta metodológica que impacta na ação no professor em situações de ensino e na ação dos estudantes em situações de aprendizagem, pois a troca entre os pares com diferentes habilidades e conhecimento se torna mais fluida e participativa.

Há integração dos acrescimentos como interação, relações interpessoais, troca de experiências e vivência em grupo presentes no ensino presencial; juntamente com as múltiplas possibilidades como autonomia e livre acesso à informação trazidas pelo ensino virtual. Tudo isso integrado pode vir a se tornar a força motriz da mudança nas formas de ensinar e aprender.

\section{DIÁLOGOS ENTRE O DESEMPENHO DOS RECURSOS DIDÁTICOS NA PERSPECTIVA DO DOCENTE E DOS ALUNOS}

Considerando os objetivos mencionados anteriormente, privilegiamos como objeto averiguar numa perspectiva comparativa o uso desses diferentes recursos de ensino (quadro/lousa, videoaula, apresentação eletrônica e software educativo) e os seus impactos no processo de ensinoaprendizagem em uma turma do ensino médio integrado.

O Quadro 1 apresenta as percepções dos discentes e da docente em relação aos maiores benefícios/vantagens da utilização dos recursos didáticos nas aulas observadas: 
Quadro1 - Benefícios/vantagens da utilização dos recursos didáticos

\begin{tabular}{|c|c|c|}
\hline RECURSOS & $\begin{array}{l}\text { TRECHOS DA FALA DA } \\
\text { PROFESSORA }\end{array}$ & FALA DOS ALUNOS \\
\hline Quadro/ lousa & $\begin{array}{l}\text { "A vantagem é talvez a questão do registro, } \\
\text { do acompanhamento do registro, com o } \\
\text { quadro você pode dar ênfase ao processo } \\
\text { passo-a-passo, fazer isso de forma cautelosa } \\
\text { com o aluno e esse tempo que muitas vezes } \\
\text { a Matemática precisa de maturidade para o } \\
\text { aluno, a compreensão do conteúdo, então o } \\
\text { quadro ajuda nesse aspecto..." }\end{array}$ & $\begin{array}{l}\text { Aluno 8: "Gostei de como foi prática, } \\
\text { enquanto a professora explicava, ela } \\
\text { escrevia e eu analisava o que ela escrevia e } \\
\text { podia, assim, tirar minhas dúvidas" } \\
\text { Aluno 9: "Acredito que em Matemática é } \\
\text { importante a utilização do quadro para } \\
\text { exemplos, resolução de contas, e utilização } \\
\text { de todo o espaço" }\end{array}$ \\
\hline Videoaula & $\begin{array}{l}\text { "[...] Eu já veja mais a videoaula como } \\
\text { contextualizar, aproveitar o vídeo para } \\
\text { trazer uma aplicação do conteúdo, pelo } \\
\text { menos é assim que eu enxergo o uso da } \\
\text { videoaula. Também trazer o ensino a } \\
\text { distância, a videoaula pode ser muito } \\
\text { importante pra questão do ensino à } \\
\text { distância, para o acompanhamento do aluno } \\
\text { a distância..." }\end{array}$ & $\begin{array}{l}\text { Aluno 2: "Traz uma diversidade no ensino, } \\
\text { saindo do "comum'. Os recursos utilizados } \\
\text { na produção do vídeo, cores, enredo, efeitos } \\
\text { e etc., chamam atenção e prendem o aluno" } \\
\text { Aluno 9: "O jeito é ótimo, porque podemos } \\
\text { aplicar o conteúdo em uma história ou } \\
\text { podemos ver por outra perspectiva" }\end{array}$ \\
\hline $\begin{array}{l}\text { Apresentação } \\
\text { eletrônica }\end{array}$ & $\begin{array}{l}\text { "Projeção de slides tem vários atributos } \\
\text { importantes no processo de ensino além da } \\
\text { ideia de fazer resumo de orientação, da aula, } \\
\text { o uso de imagens. De fato, o slide ele pode } \\
\text { trazer um aspecto bem mais atrativo do que } \\
\text { o quadro branco/lousa, porque você pode } \\
\text { utilizar um recurso que venha aliar } \\
\text { diferentes percepções: a visual, a } \\
\text { audiovisual, então o slide tem essa } \\
\text { possibilidade" }\end{array}$ & $\begin{array}{l}\text { Aluno } 02 \text { aponta que "As cores e os } \\
\text { recursos visuais que têm no slide e a } \\
\text { dinâmica de poder utilizar o quadro como se } \\
\text { fosse uma lousa digital" } \\
\text { Aluno 23: "A rapidez e a simplicidade na } \\
\text { hora da transmissão do conteúdo, sendo um } \\
\text { recurso mais dinâmico" }\end{array}$ \\
\hline $\begin{array}{l}\text { Software } \\
\text { educativo }\end{array}$ & $\begin{array}{l}\text { "[...] Com o software educativo nós nos } \\
\text { aproximamos mais da metodologia de } \\
\text { resolução de problemas na Matemática, } \\
\text { você propõe uma situação que ela vai } \\
\text { vivenciar no software e ele vai resolver com } \\
\text { o uso do software e depois retoma para que } \\
\text { nós possamos generalizar e discutir o } \\
\text { conteúdo a partir daquilo que foi vivenciado } \\
\text { pelo aluno no uso do aplicativo..." }\end{array}$ & $\begin{array}{l}\text { Aluno 36: "Achei muito interessante o uso } \\
\text { do app, pois foi prático o uso do celular para } \\
\text { uso educativo" } \\
\text { Aluno 19: "Gostei de tudo, mas em especial } \\
\text { a "liberdade" que tivemos (nos deixou } \\
\text { empolgados, pelo menos eu fiquei!)" }\end{array}$ \\
\hline
\end{tabular}

Fonte: Produzido pelos autores (2020).

Em relação às vantagens da utilização do quadro/lousa, o Aluno 8 entra em concordância com a professora quando elege o registro e ênfase dos processos, e exercitação contínua em que os registros, apontada pelo Aluno 9, como maiores benefícios da utilização do quadro/lousa, fato esse observado na aula em que no primeiro momento, a docente escreve no quadro a definição do conteúdo tratado na aula que foi "Progressão Geométrica (PG)". Pede que os alunos leiam e, em seguida, os questiona se entenderam, a partir dessa descrição escrita do termo, com o auxílio dos discentes, é construída uma fórmula Matemática (Expressão geral da PG). 
Em relação às vantagens da utilização da videoaula, a professora elege a exteriorização dos conhecimentos, que está intimamente em consonância com a análise dos alunos, como o Aluno 2, que respondeu que vê o conteúdo por uma perspectiva diferente, com outros recursos chama mais a atenção dos alunos. Já o Aluno 9 elegeu como maior vantagem do uso da videoaula a contextualização na qual os alunos puderam enxergar os conteúdos sendo aplicados, como também ver o assunto sendo explicado por outras pessoas.

A professora trouxe um jogo de xadrez para ajudar a entender o conteúdo "Soma dos termos de uma PG" e ensinou as principais características e regras desse jogo de tabuleiro, fazendo paralelo com as estratégias de guerra.

Em relação à maior vantagem da utilização da apresentação eletrônica, a docente afirma que são as inúmeras possibilidades de uso das multimídias que fazem esse recurso tão atrativo e usual. Já boa parte dos alunos, como maiores vantagens ser prático e eficiente, de acordo com o que disse o Aluno 23 que apresentação eletrônica é um dos recursos mais dinâmicos devido a sua rapidez e a simplicidade. Com uma perspectiva multissensorial do recurso similar à da professora, o Aluno 02 aponta as cores e os recursos visuais e a dinâmica dos slides podem ser comparados com as lousas digitais.

Como observado, a docente convidou os alunos a responderem na lousa, sobre a projeção que continha uma tabela a ser preenchida, algumas porcentagens de acordo com as frações, como também, outras figuras fracionadas que os discentes completaram com os valores correspondentes. Os alunos que não foram até a lousa ajudaram aos que o fizeram, ditando os resultados corretos para cada componente.

Em relação à maior vantagem da utilização do software educativo, a docente aponta a possibilidade de inovar metodologicamente, saindo das aulas expositivas e focar na resolução de problemas, possibilitando promover a interação dos alunos com os conteúdos e interagir com os alunos por meio disto, que entra em concordância com o Aluno 36 que apontou o aplicativo na aula como prático e interativo devido ao uso do celular pelos alunos. Já o Aluno 19 elegeu a liberdade que os alunos tiveram, isso pode ser motivado pelo fato de que, na sala de aula, o acesso ao sinal wi-fi é muito comprometido e os alunos tivessem que sair para acessar o site e usar o software em outros pontos da instituição com melhor sinal de internet.

Os alunos usaram o celular para acessar o app online. O projetor foi usado para mostrar aos alunos as etapas de acesso ao software educativo, no Portal da Matemática do site da OBMEP, como também, as instruções de uso da aplicação. 
É possível também que uma escolha não adequada de um desses instrumentos possa prejudicar ou dificultar o movimento de construção de determinado conhecimento.

O Quadro 2 apresenta as percepções dos discentes e da docente em relação aos maiores problemas/dificuldades da utilização dos recursos didáticos nas aulas observadas.

Quadro2 - Problemas/dificuldades da utilização dos recursos didáticos

\begin{tabular}{|c|c|c|}
\hline RECURSOS & FALA DA PROFESSORA & FALA DOS ALUNOS \\
\hline Quadro/lousa & $\begin{array}{l}\text { "O quadro quando ele tá desconectado com a turma, } \\
\text { o professor interage com o quadro, o quadro com o } \\
\text { professor e ele não tem nenhum contato com a } \\
\text { turma, esse é o maior problema..." }\end{array}$ & $\begin{array}{l}\text { Aluno 18: "O fato de ter que } \\
\text { escrever muito, e ter que prestar } \\
\text { atenção ao mesmo tempo em que } \\
\text { escrevo". } \\
\text { Aluno 16:"Só não gosta do reflexo } \\
\text { da luz na lousa, me dificulta a } \\
\text { enxergar as letras" }\end{array}$ \\
\hline Videoaula & $\begin{array}{l}\text { "Eu acho que isso até aconteceu na nossa aula, todo } \\
\text { recurso que é utilizado talvez deslocado de um } \\
\text { objetivo que é o retorno dele, a sistematização do } \\
\text { que foi assistido, fica parecendo que preencheu } \\
\text { apenas o espaço das aulas..." }\end{array}$ & $\begin{array}{l}\text { Aluno 34: "pouco dinamismo, por } \\
\text { já ser uma aula definida que não } \\
\text { permite interação" } \\
\text { Aluno } 42 \text { "A imagem do vídeo, por } \\
\text { o cabo estar quebrado, e o } \\
\text { dinamismo da aula" }\end{array}$ \\
\hline $\begin{array}{l}\text { Apresentação } \\
\text { eletrônica }\end{array}$ & $\begin{array}{l}\text { "[...] O slide, como ele está muito repetitivo em sala } \\
\text { de aula, se for apenas no sentido de palestra ele pode } \\
\text { causar o problema do desinteresse dos alunos pelo } \\
\text { slide, o que a um tempo era novidade hoje não é } \\
\text { mais, muito pelo contrário está sendo bastante } \\
\text { utilizado" }\end{array}$ & $\begin{array}{l}\text { Aluno } 39 \text { "O slide poderia ser mais } \\
\text { bem preparado" } \\
\text { Aluno } 02 \text { "O slide não era muito } \\
\text { bonito, então não me chamou muita } \\
\text { atenção" }\end{array}$ \\
\hline $\begin{array}{l}\text { Software } \\
\text { educativo }\end{array}$ & $\begin{array}{l}\text { "[...] As dificuldades sempre acontecem quando se } \\
\text { trabalha com qualquer tecnologia e as dificuldades } \\
\text { são praticamente as mesmas de acesso, algum } \\
\text { equipamento que dá algum problema. Sempre é } \\
\text { natural que no planejamento o professor tenha que } \\
\text { pensar em diversas soluções caso esses problemas } \\
\text { apareçam, isso faz parte do planejamento da aula" }\end{array}$ & $\begin{array}{l}\text { Aluno } 16 \text { "A internet estava muito } \\
\text { ruim, isso dificulta o uso do } \\
\text { aplicativo online" } \\
\text { Aluno } \mathbf{3 3} \text { "alunos dispersos pelo } \\
\text { campus" }\end{array}$ \\
\hline
\end{tabular}

Fonte: Produzido pelos autores (2020).

Quanto aos possíveis problemas/dificuldades da aula com quadro/lousa, a professora aponta que, com o uso do quadro, pode acontecer uma perda de interesse dos alunos devido à falta de interação entre docente, conteúdo e o alunado. Em consonância com a professora, o Aluno 18 aponta que a falta de interação e a dinâmica acelerada da aula afeta negativamente seu aprendizado. Já o Aluno 16, representando boa parte de seus colegas, aponta a dificuldade de enxergar os conteúdos escritos no quadro. Essas duas dificuldades ficaram evidentes em todo o 
momento da aula, já que a aula foi pausada para que os alunos pudessem escrever, como também, alguns alunos perguntavam o que havia escrito nas expressões da Progressão Geométrica.

Em relação aos maiores problemas/dificuldades da utilização da videoaula, a docente, em concordância com o Aluno 34, elegeu o pouco dinamismo que gera falta de interação. Fato percebido quando, ao início da aula, a docente comunicou que o recurso utilizado na aula seria videoaula, alguns alunos sentaram-se no chão próximo à projeção para acompanharem de perto o vídeo sobre a história do xadrez e o seu contexto com o assunto tratado da soma dos termos de uma PG. Outra dificuldade/problema foi em relação à estrutura do equipamento de projeção, que estava um pouco amarelada, motivada pelo mau contato do cabo de vídeo, o que pode ter dificultado que alguns alunos conseguissem enxergar melhor, como enfatizou o Aluno 42.

Das maiores dificuldades/desvantagens na utilização da apresentação de slides, a professora diz que o uso repetitivo faz com que esse recurso se torne desinteressante e que seja pouco interativo se não houver a exercitação e discussão dos conteúdos.

A apresentação eletrônica utilizada pela docente foi um material sobre o assunto "Porcentagem", já pronto e confeccionado por outra professora e que está disponível no site de compartilhamento de apresentações, infográficos e documentos slideshare.net. Isso motivou que o Aluno 39 e o Aluno 02 indicassem problemas na preparação, na estética, na cor e estilo dos slides, sendo que a apresentação eletrônica escolhida tinha cores fortes de fundo, letras de cor branca e alguns erros ortográficos.

Das maiores dificuldades/desvantagens encontradas na utilização do software educativo, a professora enfatizou que trabalhar com a tecnologia exige do docente que possua planos extras, pois esses recursos têm problemas inerentes às ferramentas, como de acesso e/ou equipamento.

A maior dificuldade foi o acesso à internet, sendo que a maior parte dos alunos concordou com o Aluno 16 quanto à dificuldade de acesso à internet na sala de aula. Diante desta dificuldade, inicialmente como dito pelo Aluno 33, os alunos ficaram dispersos pelo campus, (devido a atividade demandar o uso do celular e pela liberdade de eles poderem sair da sala) e saíram muitos da sala de aula, mas a docente os direcionou para que formassem os grupos e consultassem o material da última aula, que serviu como base introdutória para a atividade utilizando o software.

O Gráfico 1 representa os dados obtidos a partir das sugestões para o melhoramento, em relação às aulas com utilização dos recursos didáticos. 
Gráfico 1 - Sugestões para utilização de outros recursos didáticos

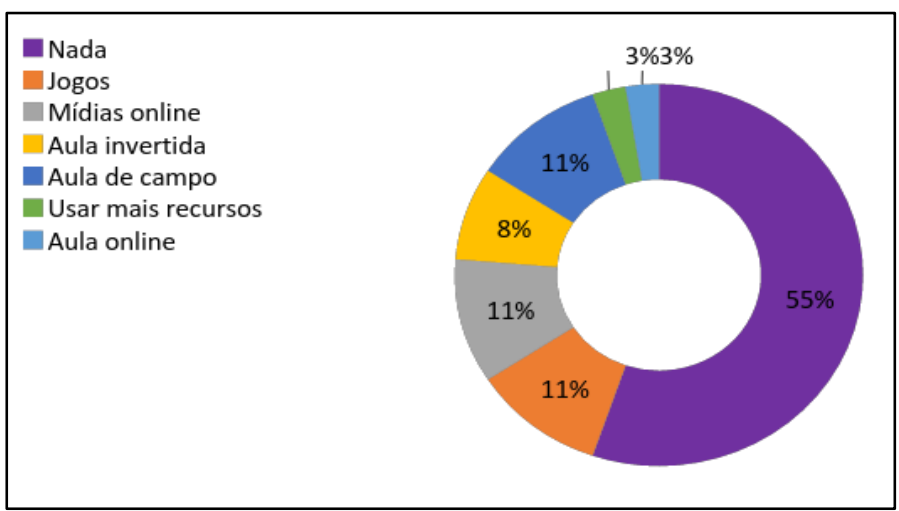

Fonte: Produzido pelos autores (2020).

Dentre as sugestões para o uso de outros/novos recursos didáticos, $10 \%$ sugeriram usar jogos; $10 \%$ propuseram fazer o uso de mídias online (redes sociais, aplicativos); $8 \%$ optaram por propor aula invertida (maior participação dos alunos); 11\% sugeriram aulas de campo; 3\% indicaram um maior uso dos recursos já utilizados; $3 \%$ aula online (em casa); e 55\% tiveram nada como sugestão para o melhoramento do uso do software educativo como recurso auxiliador do processo de ensino-aprendizagem.

\section{CONSIDERAÇÕES FINAIS: SEMPRE PROVISÓRIAS}

O desenvolvimento do presente estudo possibilitou uma análise comparativa das perspectivas dos alunos e da docente em relação à utilização de diferentes recursos didáticos. Além disso, também permitiu identificar os benefícios e dificuldades apontadas pelos discentes, pela professora e nas observações das aulas, que serviram para montar uma visão inicial que poderá contribuir para uma melhor adequação metodológica quanto ao uso desses recursos.

Com base nos dados advindos dos questionários com questões abertas aos alunos e das entrevistas com a docente, nos quais a utilização do quadro é apontada como prática em relação ao registro dos processos é visível por todos na construção das etapas de resolução dos cálculos. Além disso, a videoaula foi apontada como um recurso didático interessante pela contextualização com aspectos do cotidiano e pela disponibilidade de muitos desses materiais online (como na $\mathrm{EaD}$ ), bem como os slides, por serem uma apresentação eletrônica que engloba resumidamente conteúdos em tópicos e pelo uso de diferentes fatores (como o audiovisual), e o software educativo por usar uma metodologia de resolução de problemas (que é interessante na Matemática) e por integrar os alunos ao recurso que os faz participarem ativamente na construção dos conhecimentos. As dificuldades encontradas no uso desses recursos foram: o quadro em relação à dificuldade de 
enxergar; a escolha do material da videoaula e apresentação eletrônica; e o software educativo por problema de acesso à internet.

Considerando a importância do assunto, torna-se necessário o estudo e desenvolvimento de metodologias de ensino que possibilitem a utilização de múltiplos recursos didáticos, podendo aproveitar as potencialidades das ferramentas já utilizadas e das novas possibilidades dos novos recursos.

Nesse sentido, a utilização conjunta de diferentes recursos permite uma diversidade de métodos e técnicas que, se integrados, corroboram para uma maior eficiência em relação a alcançar os objetivos de ensino. Além disso, traz novas perspectivas do uso dos recursos didáticos para os licenciandos na formação inicial, potencializando o estudo sobre a perspectiva do ensino híbrido, além de fomentar uma reflexão sobre as múltiplas possibilidades que cada modalidade de ensino pode trazer para o aperfeiçoamento do ensino e da aprendizagem.

\section{REFERÊNCIAS}

ARAÚJO, J. C. S. Entre o quadro-negro e a lousa virtual: permanências e expectativas. In: Anais da Reunião Anual da Associação Nacional de Pós-Graduação e Pesquisa em Educação, p. 29-4, 2006.

BACICH, Lilian; TANZI NETO, Adolfo. A formação e a prática docente com o uso das tecnologias digitais: uma proposta de ensino híbrido. [S.l.:s.n]. Disponível em: https://www.researchgate.net/profile/Adolfo_Tanzi_Neto/publication/290597386_A_formacao_ e_a_pratica_docente_com_o_uso_das_tecnologias_digitais_uma_proposta_de_Ensino_Hibrido/l inks/5874a84008ae6eb871c96af7/A-formacao-e-a-pratica-docente-com-o-uso-das-tecnologiasdigitais-uma-proposta-de-Ensino-Hibrido $+\& \mathrm{~cd}=4 \& \mathrm{hl}=\mathrm{pt}-\mathrm{BR} \& \mathrm{ct}=\mathrm{clnk} \& \mathrm{gl}=\mathrm{br}$. Acesso em: 19 nov. 2019.

CANDEIAS, Cezar Nonato Bezerra; CARVALHO, Luis Henrique Pereira de. O uso de vídeoaulas como ferramenta no processo de ensino e aprendizagem em química. [S.1.:s.n], 2016. Disponível em: https://eventos.set.edu.br/index.php/simeduc/article/ download/3306/1234. Acesso em: 03 dez. 2019.

CHRISTESEN, Clayton; HORN, Michael; STAKER, Heather. Ensino híbrido: uma Inovação Disruptiva?. [S.1.]: Clayton Christensen Institute, 2015. 43 p.

FIDALGO, Fernando; MACHADO, Lucília (ed.). Dicionário da educação profissional. Belo Horizonte, MG: Núcleo de Estudos sobre Trabalho e Educação, FAE/UFMG, 2000.

GERHARDT, Tatiana Engel; SILVEIRA, Denise Tolfo. Métodos de pesquisa. Porto Alegre: Editora da UFRGS, 2009. 
GOUVÊA, Antônio Emilson Souza; PEREIRA, Elson de Menezes. O uso de tecnologia móvel: celular como apoio pedagógico na escola. In: II Colóquio de Letras da FALE/CUMB Formação de Professores: ensino, pesquisa, teoria, 2015. p. 41 - 55.

HOUAISS. Dicionário Eletrônico da Língua Portuguesa. Rio de Janeiro, RJ: Editora Objetiva, 2001.

JUCÁ, Sandro César Silveira. A relevância dos softwares educativos na educação profissional. Fortaleza, CE: Ciências \& Cognição, 2006.

LIBÂNEO, José Carlos. Didática. São Paulo: Cortez, 2015.

MORGADO, J. C. O estudo de caso na investigação em educação. Santo Tirso, Portugal: De Facto Editores, 2012.

PFROMM NETTO, Samuel. Tecnologia da educação e comunicação de massa. São Paulo: Pioneira, 1976.

RAMOS, Edla Maria Faust; ARRIADA, Mônica Carapeços; FIORENTINI, Leda Maria Rangearo. Introdução à educação digital: Guia do Cursista. 2. ed. Brasília, DF: Ministério da Educação, Secretaria de Educação à distância, 2009.

VEIGA, I. P. A. Apresentação. In: VEIGA, I. P. A. (Orgs.). Técnicas de ensino: novos tempos, novas configurações. Campinas: Papirus, 2016.

VYGOTSKY, L.S. A formação social da mente. São Paulo: Martins Fontes, 1994. 


\title{
O PROCESSO DA FORMAÇÃO DE PROFESSORES EM EDUCAÇÃO ESPECIAL E A PRÁXIS PEDAGÓGICA NO ATUAL CONTEXTO EDUCACIONAL BRASILEIRO
}

\author{
Hellyegenes de Oliveira ${ }^{1}$ \\ Francisco Marcos da Silva Figueiredo ${ }^{2}$
}

\begin{abstract}
RESUMO
O processo de formação de professores viabiliza diversos contextos desde o período colonial até a contemporaneidade nos mais diversos aspectos, sejam eles sociais, culturais ou políticos. Neste processo, destacam-se alguns tópicos a suscitar-se na referente pesquisa, dentre as quais se abordam a educação especial e a significação dos alunos, definindo o termo incluir dentro das escolas regulares e as abordagens pedagógicas para receber esse público. Em processo de finalização foram discutidas as ações e métodos de incentivos à construção das práticas de docentes, o que levaram a uma reflexão do atual cenário na qual a educação inclusiva está inserida, buscando soluções coerentes e possíveis dentro da reforma escolar, analisando quais são os aspectos e as propostas para efetivação da atuação do professor na área da educação especial. Trata-se de um estudo de natureza exploratória com abordagens qualitativas. O citado tema é polêmico, atual e transversal, tem sua base fundamentada na Constituição Federal de 1988, sendo um direito de todos a acessibilidade e igualdade a educação, porém, o cenário atual apresenta contradição no que diz respeito a estrutura física e curricular. Constata-se, ainda, que a formação dos docentes deixa a desejar e a raiz do pensamento social e cultural está imerso numa falsa ideologia inclusiva.
\end{abstract}

Palavras-chave: Formação de professores. Educação especial. Inclusão. Práxis.

\section{INTRODUÇÃO}

A formação de professores começou tardiamente em nosso país. As primeiras escolas com esse intuito passaram por um processo de abertura e fechamentos das instituições, por se tratar de um período ainda em que a maioria da população morava na zona rural e eram analfabetas. Só a partir da industrialização que se concretizou a implantação das escolas para formar docentes. Atualmente, enfatiza-se a formação de profissionais qualificados, reflexivos e críticos para atender o ensino centrado nos alunos. Para que isso ocorra é necessário treinar e formar professores dentro dos princípios discutidos nos âmbitos políticos, social e educacional.

Segundo Werneck (1993), evoluir é perceber que incluir não é tratar igual, pois todos somos diferentes e aprendizes com necessidades especiais terão oportunidades diferentes. A partir desse conceito, os resultados alcançados terão meios diferentes com os mesmos objetivos. Incluir é abandonar o estereótipo.

\footnotetext{
${ }^{1}$ Especialista em Psicopedagogia e EJA. Mestrando em Educação pela Universidade do Sul de Santa Catarina (UNISUL). E-mail: hellyegenes@ hotmail.com

${ }^{2}$ Especialista em Auditoria em Saúde e mestrando em Saúde Coletiva da Universidade Católica de Santos (UNISANTOS). E-mail: maarcos2811@gmail.com
} 
A educação inclusiva é, acima de tudo, um projeto em andamento que tem como base a igualdade de direitos e acessibilidade de todos, independente de condições socioeconômicas, religiosas, etnoculturais, e de deficiências físicas ou psicológicas. Trata-se de uma ordem moral intransferível da sociedade contemporânea. A educação inclusiva na nossa sociedade é relevante, pois garante os maiores bens da coletividade, que são o conhecimento e a cultura, e é por meio da educação que podemos mudar e inserir novos conceitos que ficarão para as gerações futuras.

A inclusão é um movimento no qual os familiares das pessoas com deficiência buscam seus direitos na sociedade e uma vida menos preconceituosa, sabendo que é compromisso de todos melhorarem a qualidade de vida dos alunos. As escolas devem estar preparadas para receber os educandos com necessidades especiais, certificando uma educação de qualidade para os mesmos, de acordo com a Resolução $n^{\circ}$ 2/2001 que instituiu as Diretrizes Nacionais para a Educação Especial.

Nos últimos anos, as políticas educacionais de formação voltadas para educação especial passaram por transformações. No entanto, há uma necessidade de melhorar a qualificação do professor, tendo como um dos indicadores a oferta de formação continuada de médio e longo prazo, pois em alguns casos a graduação deixa lacunas tornando necessária a revisão de conceitos.

Não há como incluir crianças com necessidades educativas especiais nas instituições sem antes haver um processo de qualificação de apoio aos docentes, assim como garante a Lei 7.853, de 24 de Outubro de 1989, que dispõe sobre o apoio às pessoas portadoras de deficiência e sua integração social, além de definir como crime recusar, suspender, adiar, cancelar ou extinguir a matrícula de um estudante por causa de sua deficiência, em qualquer curso ou nível de ensino, seja ele público ou privado. A pena para o infrator pode variar de um a quatro anos de prisão, mais multa.

É preciso refletir quando esse assunto é abordado. O educador tem que compreender os contextos social e histórico da exclusão e a proposta de inclusão. O mesmo tem que ter experiência e informações necessárias para se aproximar e atuar de forma correta, pedagogicamente falando, pois sabemos que os mesmos sentem-se inseguros ao receber estes alunos. Neste novo cenário em que as instituições tentam se moldar para ter um ambiente favorável à inclusão, é relevante indagar quais foram os avanços e as dificuldades que os professores viveram e ainda vivenciam para tornar possível a educação inclusiva. Em geral, os profissionais se encontram em condições desfavoráveis de trabalho, pois o ambiente esta superlotado, com escassez de materiais didáticos, ausência de recursos tecnológicos e professores com a capacitação inadequada para atender a necessidade dos alunos com deficiência. Apesar da rede de ensino público ter avançado no Brasil 
no quesito acesso, é necessário e preciso investir na capacitação de professores em educação inclusiva.

Para Kauark et al. (2010), as características da pesquisa exploratória são ainda superficiais sobre uma determinada temática, uma vez que a função é buscar um aprofundamento a fim de tornar o conhecimento do devido tema mais evidente. Segundo Zikmund (2000), os estudos exploratórios, frequentemente, são de utilidade, pois descrevem minuciosamente uma determinada situação, exploram alternativas e descobrem novas ideias.

Este estudo procura esclarecer e definir a origem de um problema e gerar mais informações para desenvolver pesquisas futuras conclusivas. $\mathrm{O}$ pesquisador pode ter algum conhecimento no tema, porém essa pesquisa será útil para o mesmo fato organizacional, isto porque pode haver inúmeras alternativas explicativas, dessa forma o pesquisador terá conhecimento, se não de todas, pelo menos de algumas delas. A pesquisa qualitativa foi escolhida por descrever a complexidade de um determinado tema, analisar a interação de certas inconstantes, entender e classificar os processos dinâmicos vivenciados por determinado grupo social.

Na pesquisa qualitativa, o objetivo e a subjetividade do sujeito são indissociáveis, dessa forma imensuráveis (PRODANOV; FREITAS, 2013). Para Gil (1999), o uso dessa abordagem evidencia o aperfeiçoamento da investigação dos quesitos relacionados a esses fenômenos e de suas relações mediante a máxima valorização da situação estudada, buscando o que era comum, mais permanece aberta para perceber a singularidades e os significados múltiplos.

\section{A EDUCAÇÃO ESPECIAL E A SIGNIFICAÇÃO DA APRENDIZAGEM DOS ALUNOS}

A educação inclusiva é um tema de debate atual, polêmico e transversal. Este tema tem sido pauta de várias conferências, simpósios e congressos no meio acadêmico, sendo um assunto de importância coletiva devido seu caráter de universalização, democratização e pluralidade; abarcando no cenário atual os diversos âmbitos executivo, legislativo e jurídico; e um grupo muito diverso da sociedade, como profissionais da saúde, educação, juristas, e a própria camada de pessoas com necessidades especiais, todas estão engajadas por uma luta e com único objetivo de fazer valer os direitos de todos.

Não há educação sem professor. O professor tem o papel primordial quando se fala em educação, pois juntamente com os alunos, são os protagonistas de um sistema que gera crescimento, cultura e desenvolvimento de toda a nação. No cenário atual da educação, existe uma base curricular para a formação de professores do ensino comum e seu alicerce tem lacunas vazias, principalmente quando se fala em educação inclusiva, uma vez que, na raiz da sociedade, tem 
grupos diferentes do "padrão" que sofrem com a exclusão, desde a educação até a inserção destes na vida profissional.

O inquietante problema vivido pelos profissionais da educação tem levado estes a se engajarem na luta pela defesa de ensino e com isso desenvolverem projetos tendo em vista a busca de alternativas para superação. Estes profissionais precisam compreender o conceito que está em transformação, para que este processo de mudança seja possível. Portanto, é preciso rever as velhas ideologias para então organizar, planejar a solução deste conflito e é dever desses profissionais buscar condições e qualificação para assumir o papel que se trata as Leis e Normas da educação inclusiva. E é dever do Estado proporcionar os instrumentos, recursos, propostas e ambiente adequado a essa nova ideologia. A formação dos profissionais deve ter caráter continuado, isto é, a busca constante por conhecimento, seja através de atualizações, pesquisas e criações de novos métodos de aprendizagem.

A educação inclusiva é um movimento de caráter universal, que envolve ações em diversas dimensões: cultural, social, política e pedagógica, que teve como estopim o reconhecimento do paradigma inclusão/exclusão, levando a discussão dos direitos já previstos na $\mathrm{CF} / 88$, a qual prevê que a educação é dever do Estado e para todos, isto é, a democratização da educação, pois concluíram que a totalidade dos educandos aprendem, participam e tem um melhor desempenho quando estes estão juntos sem nenhum tipo de preconceito. E para entender as complexidades do sistema de ensino, foi necessário colocar em debate as práticas de discriminação e criar soluções eficazes para erradicá-las.

A sociedade contemporânea e as escolas foram "forçadas" a assumir o papel de inclusão. Apesar de muito se ouvir falar em democratização, o sistema educacional permanece excluindo indivíduos e grupos considerados “anormais". Assim, o Ministério da Educação/Secretaria de Educação Especial, tendo uma visão moderna de acordo com os debates sociais apresentou um documento elaborado com caráter jurídico com as propostas da nova Política Nacional de Educação Especial na perspectiva da Educação Inclusiva.

A Educação Especial é uma modalidade que ultrapassa por todas as etapas, níveis e modalidades do ensino básico, não caracterizando como reforço ou substituição da escolarização, pois os alunos devem estar frequentando o ensino da escola regular e complementando a escolarização, em turnos contrários. E ainda segundo a LDBEN, os alunos com necessidades especiais devem ser escolarizados em conjunto com seus pares não deficientes sob supervisão de um professor capacitado nas escolas regulares. Nos Atendimentos Educacionais EspecializadosAEE. No âmbito escolar, trouxe mudanças significativas tanto no que diz respeito à organização quanto na qualidade dos resultados obtidos. 
A Lei Federal n. 9394/96 e a Resolução CNE/CBE n. 02/2001 apontam para um currículo diferenciado e flexível ao público alvo da educação especial, porém, foi com a Política Nacional de Educação Especial na Perspectiva da Educação Inclusiva (BRASIL, 2008), que ocorreram as verdadeiras mudanças: conceitual e estrutural. Podemos destacar algumas mudanças tais como: transversalidade da educação especial desde a base até a vida acadêmica; educação com atendimento especializado; formação de docentes com a visão inclusiva e com práticas na especificidade do aluno, para que este seja melhor integrado; interação da família, comunidade e escola; articulação intersetorial para implantar as políticas públicas e acessibilidade desde a estrutura física, equipamentos, transporte, comunicação e informação.

O AEE promove autonomia e independência aos alunos dentro e fora da escola. Utilizam instrumentos que possibilitam o acompanhamento, monitoramento e avaliação ao longo do processo de aprendizagem. Na Educação Infantil, o AEE encoraja o desenvolvimento precoce, que tem por função maximizar o desenvolvimento e aprendizagem dos estudantes. De maneira integral, engloba todas as modalidades da educação básica, sendo uma oferta obrigatória da instituição de ensino. $\mathrm{O}$ atendimento educacional especializado, em alguns casos específicos como alunos surdos-mudos, é ofertado tanto na categoria oral e escrita quanto na Língua de Sinais.

\section{AÇÕES E MÉTODOS DE INCENTIVO A CONSTRUÇÃO DAS PRÁTICAS DE FORMAÇÃO DE PROFESSORES EM EDUCAÇÃO ESPECIAL}

Por ser um tema atual e polêmico, a inclusão da pessoa deficiente no âmbito educacional exige uma organização no Projeto Político Pedagógico - PPP para que as peculiaridades inerentes a este público e as barreiras sejam trabalhadas no contexto escolar. Segundo Cavalcante et al (2012), ao pensar na inclusão deve-se ter uma reflexão do que é incluir na realidade do contexto educacional. Incluir significa inserir totalmente este aluno no cenário escolar; e a escola legaliza como instituição - as práticas pedagógicas e de formação dos seus aprendizes, rompendo assim, essa cadeia cultural do paradoxo inclusão/exclusão e adota meios para assegurar os direitos de aprendizagens de todos, tais meios variam da necessidade de cada aprendiz, da criatividade, observação e experiência do professor, e este profissional deve ser dotado de humanidade e perspicácia, sua formação inicial deverá ser continuada.

A inclusão é orientada pelas diferentes práticas pedagógicas num mesmo ambiente para que o aprendiz com alguma deficiência consiga acessar o objeto do seu desenvolvimento e crescimento. É necessário saber que o aluno deverá ter acesso a todos os instrumentos e por todas as vias, chegando às metas esperadas e banindo todos os obstáculos existentes. O docente deverá 
buscar os conhecimentos em vias alternativas tais como: jogos, brincadeiras e mais diversas estratégias para repassar e chegar ao objetivo proposto.

O currículo hoje é considerado a base estrutural do qual faz com que as ações sejam dinâmicas e sistematizadas de acordo com os esforços pedagógicos. É de relevância citar que estes currículos são planejados pelos próprios professores e elaborados do ponto de vista multicultural, isto porque o âmbito escolar abrange uma diversidade étnica, social e cultural. Ao centrar na educação inclusiva, os currículos tornam-se mais convergentes às práticas de inclusão daqueles antes excluídos desse cenário, que por conveniência as velhas práticas e hábitos, acabaram tendo a função de manter a escola sem as mudanças necessárias para essa nova visão de incluir, estagnando em um sistema antigo e inadequado as novas propostas do PNE e da LDBEN.

É importante entendermos que incluir não significa o empobrecimento dos conteúdos básicos da grade curricular e muito menos quando o aluno com deficiência é parte integrante de sistema educacional. Os currículos não devem ser entendidos como um documento alternativo ou um sistema paralelo de ensino, pois incluir significa fazer parte do todo. A escola inclusiva é uma pequena parte de um projeto maior, isto é, a sociedade precisa assumir seu papel na construção de cidadãos críticos e reflexivos, então deve ser uma preocupação não só dos profissionais e pesquisadores na área de educação.

Segundo Barbosa (2003), é de relevância a participação da sociedade nesse projeto de inclusão escolar porque a educação é a via mais segura para todos, principalmente para aquelas pessoas que convivem com a exclusão É através da educação que teremos a formação de uma nova geração de cidadãos, com um novo raciocínio e atitudes comportamentais inclusivas. A formação de docentes de ensino comum na perspectiva inclusiva é ponto chave de debate, pois estes profissionais são protagonistas que desempenham o papel importante para construir cidadãos com mentalidade inclusiva e sua contribuição é significativa nesse grande projeto.

Para Omete (1995), os docentes do ensino comum precisam ter trânsito livre para o sistema de ensino especial, portanto esses professores precisam receber, na sua formação inicial ou em especializações, conhecimentos básicos sobre alunos com deficiências, os métodos, instrumentos e recursos voltados para esse grupo, pois só assim esses profissionais serão qualificados para exercer em salas comuns com a presença de alunos especiais. Os professores precisam de uma formação sólida, científica, sistematizada e qualificada para ser considerado um bom profissional, assim a sua teoria, prática e experiência no campo são recursos a serem utilizados para atender alunos com necessidades educacionais especiais.

Para exercer a sua formação, o professor deve buscar conhecimentos no exercício profissional e conhecimentos específicos na área de sua atuação, pois sua formação permitirá o 
aprofundamento de caráter interativo e interdisciplinar nas escolas regulares (BRASIL, 2008). Para assegurar a implementação das políticas públicas valorizando intersetorialidade, no seu currículo deve contemplar conhecimento de gestão de sistema, visando o desenvolvimento do projeto com os demais profissionais das outras áreas e a acessibilidade à estrutura e ações de caráter social, trabalho e justiça. Pode-se notar a importância do trabalho multiprofissional, integrando diversos setores. A escola, como dita anteriormente, é parte de um projeto maior, que o público alvo deve ser o maior beneficiado dos seus programas e projetos, portanto, todo grupo profissional que exerce as intervenções deve cumprir os princípios constitucionais que preveem a igualdade de condições para manter o acesso e a permanência e a continuidade em todos os níveis de educação.

É relevante expressar que o professor tem um papel elementar na construção da educação inclusiva porque cabe a ele uma parcela expressiva nesse grande projeto. É bom destacar a tentativa de dissociação entre a formação de professor de ensino comum e do professor de ensino especial, pois, de acordo com Omete (1995), houve grandes debates na década de 80, nos Estados Unidos, pois alguns críticos apontavam a mesma responsabilidade de ambos os sistemas pela educação dos alunos especiais. Por isso, podemos afirmar que a formação do professor deve ter uma base sólida, no que diz respeito às questões e os recursos que podem ser aplicados na educação inclusiva. Em 11 de setembro de 2001, foi estabelecida a resolução CNE n.2, no artigo 18:

São considerados professores especializados em educação especial aqueles que desenvolveram competência para identificar as necessidades educacionais para definir, implementar, liderar e apoiar a implementação de estratégias de flexibilização, adaptação curricular, procedimentos de didáticos pedagógicos e práticas alternativas, adequados ao atendimento das mesmas, bem como trabalhar em equipe, assistindo professor de classe comum nas práticas que são necessárias para promover a inclusão dos alunos com necessidades educacionais especiais. (BRASIL, 2001).

Esta Resolução definiu a função e o perfil dos professores da educação especial e aponta como alternativa, a licenciatura em educação especial ou em uma de suas áreas. O problema ainda persiste na história em formar e organizar a atuação dos professores na área de comprometimento. Para Ferreira (1999), é necessário abandonar a formação de docentes em categorias ou comprometimentos, isto é, cegos, surdos, deficientes mentais e autistas, entre outros. No IV Congresso Estadual Paulista, em maio de 1996, a formação de educadores foi alvo de debates. Para uns, a ideia de que a tradição e a legislação determinavam a formação e atuação do professor especialista por categoria de deficiência, é considerada inadequada, porque desse ponto vista cada categoria tende a ser olhada peculiarmente pela sua necessidade, assim teria demanda de recursos humanos, metodológicos, materiais de uso exclusivo daquela categoria; sendo contrário ao que diz a Lei de Diretrizes e Bases da Educação Nacional e a própria Constituição Federal (1988). 
De acordo com Omete (1995), a organização dos currículos e de serviços centrada na deficiência especifica é facilitada, pois contribui para um planejamento curricular e de serviços voltados para um melhor planejamento e desempenho da categoria específica, porém seria um problema utilizar as categorias como rótulos, isso porque é necessário ter critérios e cuidados com essas padronizações. Ainda segundo a autora, para que não ocorra o pecado do exagero com método de categorização, as semelhanças e as diferenças entre os integrantes das categorias não venha somente destacar como qualidades centrais as deficiências das pessoas portadoras de necessidades especiais, criando uma falsa ideia de semelhança e igualdade entre o que de fato é uma realidade social e natural da categoria.

Na educação inclusiva é indicado o critério e cuidado em duas ocasiões. Na primeira, quando o paradigma da inclusão não interessar as características gerais, como física ou mental. Essas características não devem servir como definição e organização dessa categoria, podendo fazer uso quando tiver necessidade de um tratamento específico e diferenciado para um melhor desenvolvimento, então a organização do sistema de categoria é justificada. Na segunda ocasião, é na própria utilização dessas categorias. Para que sejam validadas, é necessário o seu embasamento em uma quantidade mínima de critérios, de maneira que evite a igualdade dentro da categoria, exceto quando se falar em adjetivos específicos.

Sabendo que a inclusão é uma questão política e didático-pedagógica, devemos pontuar que a tarefa das instituições de Ensino Superior não é apenas graduar docentes na perspectiva inclusiva, e achar que nas pesquisas encontraremos soluções didático-pedagógicas para alunos com necessidade educacional especial; isso porque a atividade de ensino e de pesquisa deve estar em sincronismo com elaboração de políticas públicas. Problemas de ordem política não podem ser resolvidos com pesquisas voltadas para área de Educação, apesar de que a nata intelectual do país é favorecida com ideias e planejamentos educacionais. Como exemplo, existe um intenso trabalho de programas de graduação e pós-graduação de pouca visualização da coletividade, a qual esses programas deverão alcançar. Somente com debate daqueles que vivem no contexto que o problema está inserido, sem utopias e uma margem de erro significativa, poderemos falar em inclusão definitiva.

\section{CONSIDERAÇÕES FINAIS}

A educação inclusiva está bem fundamentada, no arcabouço jurídico atual, tendo como fundamentos Decretos, Normas e Leis que legalizam que todas as escolas, desde 2016, tivessem em seus programas e projetos a inclusão de pessoas portadoras de necessidades especiais. Dessa forma, cumprindo o que está na Constituição Federal de 1988 e na LDBEN, para promover o 
acesso e igualdade de todos. Apesar de muitas teorias e debates, a inclusão não foi efetivada plenamente, pois é um desafio com a complexidade para além da área educacional, tendo o âmbito político, social, cultural que devem estar em sincronismo com todos os demais. O primeiro grande avanço para a educação especial é suprir todos os recursos para a concretização e implantação da educação inclusiva, desde os recursos humanos, métodos, materiais, aperfeiçoamento profissional continuado e práticas dentro da área da educação inclusiva.

Acima de tudo, é necessária uma modificação na raiz da sociedade, pois o professor tem um papel essencial, juntamente com a família e a sociedade, de agente transformador no que diz respeito à cultura e pensamento. Não podemos pensar em inclusão, sem antes sermos os protagonistas em incluir. É somente dessa forma que os objetivos propostos na Lei e Normas darão seus primeiros passos rumo ao sucesso da educação inclusiva. Apesar de muitos debates sobre inclusão, principalmente no âmbito educacional, esse tema ainda está obscuro, pois na leitura de alguns artigos percebemos a dificuldade de alguns profissionais para apontar ações que poderiam auxiliar na inclusão de alunos com necessidades especiais.

Para tanto, são necessárias atitudes imediatas - debates sinceros, coerentes e possíveis entre gestores, família, comunidade, escola - para que possam chegar a uma conscientização sobre as fragilidades e desafios que serão enfrentados pós-reforma, pois ainda há uma acomodação disfarçada socialmente, necessitando de uma reflexão profunda sobre o verdadeiro sentido de incluir.

A formação de professores, por ser de caráter continuado, precisa de uma base sólida, empírica e sistematizada, e os cursos superiores devem atentar que para formar profissionais capacitados e qualificados é necessário fornecer a prática aos discentes, que posteriormente chegam ao campo de trabalho sem uma experiência e qualificação adequada. A maioria dos profissionais que iniciam a sua vida profissional saindo direto do curso de graduação chega quase que zerados ao ambiente escolar, quando se fala em educação inclusiva, então é necessária uma especialização na área. Também, é necessário rever a grade curricular universitária, a qualificação dos docentes que saem do curso de Pedagogia para atuar num cenário complexo, que é o campo da Educação.

\section{REFERÊNCIAS}

BARRETO, K. C. C.; BARRETO, W. P. A formação dos professores e a inclusão escolar. Brasília: [s.l.]. Disponível em: https://ifgoiano.edu.br. Acesso em: 20 de fev. de 2020.

BRASIL, Conselho Nacional de Educação. Resolução CNE n.2, de 11 de setembro de 2001. Resolução que institui Diretrizes Nacionais para a Educação Especial na Educação Básica. Brasília. 
. Decreto Lei $n^{\circ}$ 8.530, de 2 de janeiro de 1946. Lei Orgânica do Ensino Normal. Disponível em: www.soleis.adv.br. Acesso em: 15 de março de 2020.

. Lei n 5.692/71, de 11 de agosto de 1971. Diário oficial da União, Brasília, 12 ago. 1971.

. Lei no 9394, 20 de dezembro de 1996. Lei de Diretrizes e Bases da Educação Nacional.
$\begin{aligned} & \text { Brasília: } \\ & \text { MEC, }\end{aligned} \quad 1996 . \quad$ Disponível
http://portal.mec.gov.br/seesp/arquivos/pdf/lei9394_ldbn2.pdf. Acesso em: 19 de fev. de 2020.

Parecer 349-72. Documento, n. 137, p. 155-173, abr. 1972.

. Marcos Politico-Legais da Educação Especial na Perspectiva da educação Inclusiva.

Secretaria de Educação Especial. Brasília: Secretaria de Educação Especial. 2010.

. Politica nacional de educação especial na perspectiva da educação inclusiva. Brasília: MEC/SEESP, 2008.

DUARTE, Sergio Guerra. Dicionário brasileiro de educação. Rio de Janeiro: Antares/Nobel, 1986.

FERNANDES, Cláudia, O.; FREITAS, Luiz Carlos. Indagação sobre currículo: currículo e avaliação. Brasília: MEC/SEB, 2007.

FERREIRA, M. C. C. Construindo um projeto politico-pedagógico para a formação de educadores no contexto da Educação Especial. In: BICUDO, M. A.V; SILVA JUNIOR, C. A. (Orgs.). Formação do educador e avaliação educacional. São Paulo: Ed. UNESP, 1999. v.2, p.139-148.

GIL, A. C. Métodos e técnicas de pesquisa social. 5. ed. São Paulo: Atlas, 1999.

GOTTI, M. O. Integração e inclusão: nova perspectiva sobre a prática da educação especial. In: MARQUESINE, M. C. et al. (Orgs.). Perspectivas multidisciplinares em Educação Especial. Londrina: editora UEL, 1998. p. 365-372.

KASSAR, M. C. M. Educação Especial na perspectiva da educação inclusiva: desafios da implantação de uma política nacional. Educar em Revista, Curitiba, n. 41, p. 61-79, jul./set. 2011.

KAUARK, F. S.; MANHÃES, F. C. \& MEDEIROS, C. H. Metodologia da pesquisa: um guia prático. Itabuna: Via Litterarum, 2010. Disponível em: http://www.pgcl.uenf.br/2013/download/livrodemetodologiapesquisa2010.pdf. Acesso em: 22 de fev. 2020.

PRODANOV, C. C.; FREITAS, E. C. de. Metodologia do trabalho científico: Métodos e Técnicas da Pesquisa e do Trabalho Acadêmico. 2. ed. Novo Hamburgo: Feevale, 2013. Disponível em: http://docente.ifrn.edu.br/valcinetemacedo/disciplinas/metodologia-do-trabalhocientifico/e-book-mtc. Acesso em: 10 de jan. 2020.

REIS FILHO, Casemiro. A educação e a ilusão liberal. 2. ed. Campinas: Autores Associados, 1998.

SÃO PAULO. Decreto 27, de 12/03/1890. In: Coleção da Leis e Decretos do estado de São Paulo. Tomo I- 1889-1891. São Paulo: Impressa oficial do Estado, 1909. 
TANURI, Leonor Maria. História da formação de professores. Revista Brasileira de Educação, n. 14, p. 61-88, maio/ago., 2000.

UNESCO. Declaração de Salamanca e Enquadramento na Área das Necessidades Educativas Especiais. Lisboa: Instituto de Inovação Educacional. 1994. Disponível em: http://portal.mec.gov.br/seesp/arquivos/pdf/salamanca.pdf. Acesso em: 05 de mar. de 2020.

WERNECK, Claudia. Ninguém mais vai ser bonzinho na sociedade inclusiva. Rio de janeiro: WVA, 1997.

ZIKMUND, W. G. Business research methods. 5.ed. Tx: Dryden 2000. 


\section{O PAPEL DA EDUCAÇÃO NA FORMAÇÃ̃O DO CIDADÃO: INCLUSÃO SOCIAL EM SÃO PAULO}

Francisco José Pires ${ }^{1}$

\section{RESUMO}

Ao longo desta pesquisa, compartilhei com educandos, homens e mulheres, trabalhadores paulistanos, suas alegrias diárias, seus sofrimentos, a luta pela sobrevivência, enfim suas vidas. Como seres históricos, eles dispunham de experiência e da capacidade de, intervindo no espaço, conhecer este espaço, cujo trabalho cotidiano consiste em procurar seu destino pelas trilhas da cidade de São Paulo. O presente trabalho tem como tema o papel da educação na formação do indivíduo para a Inclusão Social em São Paulo a partir de 1980. Procura-se analisar a questão das condições de trabalho em que vive a população de São Paulo e o papel da educação nesse contexto, uma vez que pode inevitavelmente definir o tipo de cidadão que ocupa os espaços dessa Metrópole Sul-Americana, na qual pobreza e riqueza andam de mãos dadas numa promiscuidade dificilmente vivenciada na história da humanidade. Esse paradoxo provém da constatação de que as questões das políticas educacionais e do desemprego generalizado se converteram, na década de 1990, em problemas emergentes carentes de soluções por parte do poder público. Nesse sentido, entender o papel da educação nesse contexto pode contribuir para o debate desta problemática, assim como para a avaliação e formulação de alternativas possíveis para o enfrentamento da educação em São Paulo, face às exigências da atualidade.

Palavras-chave: Educação. Formação do Cidadão. Inclusão Social.

\section{INTRODUÇÃO}

O presente trabalho tem como tema o papel da educação na formação do cidadão para a Inclusão Social em São Paulo a partir de 1980. Procura-se analisar a questão das condições de trabalho em que vive os atores sociais e o papel da educação nesse contexto, que vai inevitavelmente definir o tipo de cidadão que ocupa os espaços dessa Metrópole Sul-Americana.

As transformações estruturais do Estado, implementadas no Brasil, não deram conta de resolver o problema a curto e médio prazo. Nesse sentido, entender o papel da educação nesse contexto pode contribuir para o debate desta problemática, assim como para a avaliação e formulação de alternativas possíveis para o enfrentamento da crise da educação no Brasil, especialmente em São Paulo, objeto desse estudo, face às exigências atuais.

No bojo das discussões e reflexões que foram provocadas com a implantação da nova Lei de Diretrizes e Bases da Educação Nacional - Lei n. ${ }^{\circ}$ 9394/96, observa-se que já no Título II "Dos Princípios e Fins da Educação Nacional" em seu artigo 2. aqui reproduzido: "A educação, dever da família e do Estado, inspirada nos princípios de liberdade e nos ideais de solidariedade humana, tem por finalidade o pleno desenvolvimento do educando, seu preparo para o exercício

\footnotetext{
1 Doutor e Mestre em Integração da América Latina, Jornalista, Geógrafo e Pedagogo. E-mail: fco.pires@hotmail.com.
} 
da cidadania e sua qualificação para o trabalho", procura-se garantir uma educação voltada ao exercício pleno da cidadania e à preparação para o mundo do trabalho. No entanto, as pesquisas apontam que com um processo de globalização desigual, a incerteza global torna-se cada vez maior pela ausência de processos educativos consistentes que possam atender à demanda educacional e profissional do mundo atual.

Neste cenário, faz-se necessário o entendimento de que a produtividade do trabalhador não é mais avaliada pela sua mestria numa determinada tarefa, mas sim pela sua habilidade de aprender, transferir e aplicar o aprendido, num contexto de aprendizagem contínua. A competência do trabalhador, na chamada "sociedade Pós-industrial", passa a ser determinada pela sua capacidade de relacionar e de integrar conhecimento e trabalho. Este trabalho pretende ampliar o estudo nesta área, dada a importância e complexidade de que se reveste.

Naturalmente, as considerações colocadas ao longo do estudo terão seu conteúdo referenciado ao contexto latino-americano, especialmente a região metropolitana de São Paulo, no que se refere à formação do cidadão para inclusão social, porém, trata-se de um esforço de compreensão de uma temática posta para discussão e, em nenhum momento tem-se a pretensão de esgotar o assunto, dada a abrangência e complexidade da questão.

Procura-se, entretanto, apresentar alguns resultados da pesquisa realizada, cientes de que, estes, estão sujeitos a omissões ou até mesmo interpretações redundantes, tendo em vista a compreensão parcial das leituras que se fizeram necessárias durante o processo de investigação. Em consequência, avançar na pesquisa sobre a formação do cidadão para a inclusão social em São Paulo significa aprofundar a compreensão das transformações que perpassa o espaço da cidade, o que equivale a um melhor entendimento da organização da sociedade e de suas estruturas no passado e no presente.

Delimitou-se esse período porque foi a partir de 1980 do século XX, com o processo de reabertura política no Brasil e, principalmente nos anos 90, com a reestruturação econômica, que São Paulo passou a conviver mais intensamente com as dificuldades enfrentadas pelo cidadão no que diz respeito a sua formação e ao mercado de trabalho.

\section{ALGUMAS CONSIDERAÇÕES SOBRE O PROBLEMA}

O desemprego em massa que se faz presente no Brasil, na última década do século XX, torna-se um problema emergente, ou seja, o grande desafio enfrentado pelo país é preparar o cidadão para o mercado de trabalho, e, ao mesmo tempo, criar postos de trabalho para atender a demanda de mão-de-obra, tarefa que não tem sido fácil para os países de economia dependente. 
Nesse contexto, identifica-se na Região Metropolitana de São Paulo, por um lado, uma crise sem precedente na educação, face as políticas governamentais implementadas pelo Estado, atendendo às exigências das Agências Internacionais de Financiamento como, o Banco Mundial e o BIRD ${ }^{2}$. Por outro lado, uma crise do emprego caracterizada, basicamente, pela diminuição assustadora do emprego formal, aumento do emprego informal, precarização das relações de trabalho, perda do poder de compra dos trabalhadores e, consequentemente, aumento das desigualdades sociais.

A reflexão que nos ocupa constrói-se a partir de um trabalho de recopilação, revisão bibliográfica e análise de dados, que toma dimensão à medida que se considera as políticas públicas implementadas pelo governo brasileiro no sentido de atender às demandas de formação de mão-de-obra, possibilitando assim a inclusão social.

A realização desta pesquisa compreende a superação de algumas etapas no processo de investigação científica. Para análise das políticas públicas de formação do cidadão e o papel da educação no espaço estudado, foram elencadas algumas variáveis com o intuito de se obter o maior número de informações que demonstrem com fidedignidade a realidade estudada.

O crescimento acelerado das cidades propiciou sérios problemas sociais, como: educação, desemprego, transporte coletivo sucateado, moradia, saúde, lazer, entre outros. Visto que não ocorreram nestes setores alterações estruturais significativas que atendessem às demandas e pressões sociais.

Um ponto nevrálgico a ser pensado é o diagnóstico das causas de fracasso escolar e o papel da educação nesse processo, pois ao mesmo tempo em que se convive com um desemprego em massa e com novas exigências em relação ao perfil do trabalhador, não se tem dados significativos sobre uma formação permanente efetiva para atender a demanda de mão-de-obra nos moldes que o mercado exige.

Trata-se de uma questão crucial, pois é possível presumir que a maior parte das políticas de formação tem um diagnóstico das causas em suas bases, e isso é o que determina a direção e o objetivo dessas políticas.

\section{REFLEXÕES ACERCA DAS HIPÓTESES}

Ao se estudar as políticas públicas de formação do cidadão para a inclusão social implementadas em São Paulo, como aporte para viabilizar o processo de urbanização de seus

\footnotetext{
${ }^{2}$ Banco Internacional para Reconstrução e Desenvolvimento.
} 
espaços, vale discutir as questões emergentes que deram origem aos grandes movimentos sociais urbanos.

A reestruturação econômica implementada no Brasil sob a ótica do neoliberalismo com a diminuição do tamanho do Estado e consequentemente de sua intervenção, na economia, nos equipamentos públicos e na sociedade, suscita um novo entendimento da eficiência e eficácia do estado em relação às décadas anteriores.

Nesse sentido, busca-se discutir ao longo da pesquisa algumas questões, tais como:

- Que medidas poderiam desencadear um processo de recuperação da Educação Básica (gestão, professor, métodos, recursos financeiros, recursos físicos, etc.);

- Qual o papel do Estado e da educação na formação do cidadão para o mercado de trabalho?

- Qual a função social da escola?

- Como perceber no processo de modernização aspectos das relações sociais capitalistas e seu impacto no conjunto da sociedade?

Essas questões abrem uma perspectiva de análise capaz de se fazer uma leitura próxima da realidade, no sentido de contribuir na compreensão de como se deu a intervenção do Estado a partir dos anos 80 no Brasil, reelaborando aspectos de própria vida social. A relação políticas públicas de geração de empregos e educação é o paradigma com o qual se espera responder tais indagações.

\section{O PAPEL DA EDUCAÇÃO NA FORMAÇÃO DO CIDADÃO PARA INCLUSÃO SOCIAL EM SÃO PAULO A PÁRTIR DE 1980}

O início da década de 1990 representa o começo de um novo processo para o desenvolvimento socioeconômico brasileiro. Haver alcançado a Institucionalidade democrática significou a evolução política do País a partir de 1980. Acerca das transformações sofridas no final do século XX, Dourado (2001) afirma:

$\mathrm{O}$ mundo do trabalho e da produção expressa às significativas transformações, originadas pelo incremento das relações sociais capitalistas e traduzidas, nesta virada de século, pelo expressivo avanço tecnológico e pela globalização do capital e do trabalho. Essas transformações societárias redimensionam o papel da educação e da escola (DOURADO, 2001, p. 49).

$\mathrm{O}$ autor argumenta que as agências educacionais passam a ser vislumbradas como um dos elos de socialização dos conhecimentos técnico-científicos historicamente produzidos pelo desenvolvimento de habilidades, capacidades e competências sociais requeridas, predominantemente, em sintonia com o setor produtivo, no qual "educação formal e a qualificação 
formal são situados como elementos de competitividade, reestruturação produtiva e da “empregabilidade" (FRIGOTTO, 1998, p.15). Nesse sentido, o papel da educação tornou-se fundamental, como premissa para garantir o projeto oficial de desenvolvimento implementado pelo governo brasileiro.

Desta forma, a década de 1990 caracterizou-se pela introdução de reformas educacionais no Brasil, sobretudo no que se refere ao combate ao analfabetismo, assim como a democratização do acesso e permanência escolar. Nesta fase, a escola democratizou o acesso, porém não garantiu a permanência dos alunos, uma vez que as condições oferecidas para essa escolarização não foram alteradas/modificadas, refletindo diretamente na baixa qualidade de ensino. Parece aplicar-se, aqui, a afirmação de Oliveira (2001) com relação a essa questão:

\begin{abstract}
Assim, a década de 1990 será marcada pela tentativa de reformas educacionais que busquem, sobretudo, estender a educação a toda população e erradicar o analfabetismo, porém contaminadas de uma compreensão restritiva do termo educação básica. Ao lado das exigências de universalização do acesso à educação, procurava-se combinar medidas de racionalidade técnica para a gestão dos recursos públicos aplicados no setor. A combinação penosa desses dois fatores resultou na maior oferta de serviços educacionais pelo poder público, porém com o achatamento dos custos empregados, colocando em risco a tão propalada qualidade (OLIVEIRA, 2001, p.109).
\end{abstract}

A análise das tendências pedagógicas no Brasil, principalmente a partir das transformações introduzidas pela Lei Federal 9394/96 deixa evidente a influência dos grandes movimentos educacionais internacionais, da mesma forma que expressam as especificidades da história política, social e cultural desse país, a cada período em que são consideradas. Atualmente podem ser claramente identificadas, tanto em nível de políticas educacionais como em nível de estabelecimentos de ensino, manifestando-se com maior ou menor intensidade, dependendo das intenções educativas dos agentes envolvidos.

A partir de 1988, com a promulgação da atual Constituição Brasileira, a Educação Básica passou a compreender desde a Educação Infantil, o Ensino Fundamental e até o Ensino Médio. Nesse sentido, a Lei 9394/96, que regulamenta a matéria, tem a flexibilidade característica principal. No entanto, as transformações introduzidas pela referida Lei, não resolve o problema da educação no Brasil, pois ao mesmo tempo em que permite a flexibilidade, no que se refere à classificação e reclassificação de alunos em ano/série/ciclo - tendo como parâmetro a relação idade e série; explicitando o papel da família, da escola e do educador; e possibilitando a cada Unidade Escolar construir o seu projeto político pedagógico - não traz ações efetivas que garantam a qualidade, uma vez que as políticas públicas de formação permanente do profissional de educação e a melhoria das condições de aprendizagem dos alunos não saem do plano da Lei. 
Com a possibilidade da progressão continuada, com a formação de Ciclos, mascarou-se uma situação de descaso das administrações públicas, pois a comunidade escolar não foi preparada para atuar dentro dessa nova perspectiva, gerando um desconforto entre os educadores, pais e estudantes, assim como provocando um grande descompasso entre o ensino e a aprendizagem. Assim sendo, a escola não vem respondendo as reais demandas educacionais. Rodrigues (1999) chama a atenção para esta questão:

\begin{abstract}
A educação foi confinada ao espaço e tempo escolares e estes aos interesses privados do mercado. Na escola, como no mercado, tudo se torna provisório, sucessivo, fragmentado, útil ou inútil conforme os interesses que vão definindo o desdobrar de suas atividades. Prédios e pessoas, equipamentos e conteúdos, métodos e valores são dissolvidos e reificados segundo propósitos momentâneos. O passado se reduz a abandono, o futuro a incertezas e o presente erigido em única força motriz do mundo. A escola deixa de ser um espaço e tempo de formação humana para se converter em lugar e tempo de fixação de destinos individuais. A escola passa a ter missão, atribuída de fora. Se lhe anunciam princípios de autonomia, estes não trazem em si qualquer significado, pois não guardam relação com o seu fim, apenas com os seus meios (RODRIGUES, 1999, p. 29-30).
\end{abstract}

Nesse sentido, é preciso dar um real significado a escola para que efetivamente ela exerça sua função social, e esse equilíbrio será materializado a partir do momento em que o educador seja valorizado, principalmente no que se refere a sua formação. Por isso, cada educador, ao adentrar o espaço de sua ação educativa, deve lembrar que, acima de tudo, está ali para a formação da pessoa humana em sua totalidade.

Vale registrar que a valorização do magistério, quer seja em condições de trabalho, quer seja em termos de salário, ou mesmo em relação à formação permanente dos educadores, não aconteceu, refletindo diretamente na qualidade da educação. Hoje, o Brasil não precisa fazer festa pela inauguração da Escola, contudo é preciso refletir, analisar e repensar as condições em que o aluno se forma.

Nesse contexto é preciso refletir sobre a identidade do educador enquanto profissional, porém, acima de tudo como ser humano, pois não é possível separar a atividade laborativa do jeito de ser de cada um, com suas características individuais que, embora atue num coletivo possui suas especificidades. Acerca disso, Nóvoa (1992) afirma:

Não é possível separar o eu pessoal do eu profissional, sobretudo numa profissão fortemente impregnada de valores e ideais [...] Ser professor obriga a opções constantes, que cruzam a nossa maneira de ser com a nossa maneira de ensinar (NÓVOA, 1992, p. 7-9). 
Diante disso, não há dúvida de que o papel do educador é de fundamental importância na formação do cidadão. No entanto, há de se considerar que este, tem que refletir incessantemente sobre a sua prática, pois ela implica diretamente na formação do outro. Para tanto, faz-se necessário que o professor se aproprie de múltiplos saberes e compreenda as transformações aceleradas por que passa a sociedade contemporânea, no sentido de construir sua identidade. E mais uma vez Nóvoa (1992) que chama a atenção para esta questão ao reiterar: "A identidade não é um dado adquirido, não é uma propriedade, não é um produto. A identidade é um lugar de lutas e conflitos, é um espaço de construção de maneiras de ser e de estar na profissão" (NÓVOA, 1992, p.1).

Nesse sentido, é preciso que o professor em sua atividade profissional transcenda o ato de ensinar conteúdos conceituais, atitudinais e procedimentais e atue em outro patamar o de educador, que tem uma função eminentemente política.

Cabe aqui, o registro do legado de Gramsci (1978b) ao afirmar que a transformação da sociedade somente será possível de forma efetiva, se esta estiver articulada com uma "reforma intelectual e moral" (GRAMSCI, 1978b, p.8-9), capaz de promover a transformação da sociedade, democratizando as oportunidades de forma igualitária.

Isso significa que,

\begin{abstract}
$\mathrm{Na}$ escola a consciência crítica e transformadora dos educandos só pode dar-se a partir da apropriação de uma visão de mundo elaborada que esteja comprometida com a construção de uma nova ordem social, ou seja, a partir da apropriação de uma nova ideologia, no sentido em que esta é dada pelo próprio Gramsci, como 'uma concepção do mundo que se manifesta implicitamente na arte, no direito, na atividade econômica, em todas as manifestações de vida individuais e coletivas (GRAMSCI, 1978a apud PARO 2001, p.42).
\end{abstract}

É nesse universo, que a escola e todos os sujeitos envolvidos no processo ensino e aprendizagem precisam atuar, ou seja, garantir espaço para que o conjunto da comunidade educativa possa elaborar e reelaborar suas ideias a partir de uma leitura de mundo que propicie estreita relação entre o texto e o contexto.

\title{
A FUNÇÃO SOCIAL DA ESCOLA
}

A alta complexidade dos problemas que envolvem o cotidiano da escola e sua função social, as transformações de valores, culturas e saberes que se processam cada vez mais rapidamente, o grau de incerteza global por que passa a sociedade contemporânea, exigem esforço 
intelectual e mental de todos aqueles que estão direta ou indiretamente envolvidos com a questão da educação e do conhecimento. Nas palavras de Greco (1996):

[...] Hoje, tão importante quanto o resultado específico do conhecimento que se adquire é a percepção do seu alcance, das suas intercorrências e, sobretudo, das suas consequências. E isso transcende o limite restrito das ciências, encontrando interfaces óbvias com outros níveis de conhecimento. Sobretudo para aqueles que se empenham nas atividades em que é fundamental a produção de bens simbólicos, como os constituintes do processo de mediação social, faz-se mister a busca de um novo paradigma para a abordagem da realidade - "um conhecimento do conhecimento" como denominou Edgar Morin, onde a ciência tenha um papel integrado com os demais níveis do saber e não uma supremacia como queria Comte com sua "lei dos três Estados". Um papel de interação e não de superioridade (GRECO, 1996, p 56).

Portanto, faz-se necessário repensar a função social da escola, uma vez que ela enfrenta o desafio de atender as novas exigências educacionais, resultantes dos avanços tecnológicos e da necessidade de superar desigualdades educacionais decorrentes de um processo de exclusão de ordem econômica e social, resultante do modelo econômico adotado na América Latina, em especial o Brasil neste estudo.

Nesse contexto, apontamos na literatura especializada as ideias de Pimenta (1998) quando afirma que:

\begin{abstract}
A tarefa da escola é inserir as crianças e jovens tanto no avanço como na problemática do mundo de hoje, através da reflexão, do conhecimento, da análise, da compreensão, da contextualização, do desenvolvimento de habilidades e de atitudes. A identidade da escola nesse processo é garantir que as crianças e jovens sejam capazes de pensar e gestar soluções para que se apropriem da riqueza da civilização e dos problemas que essa mesma civilização produziu. É nessa contradição que se define a identidade da escola hoje (PIMENTA, 1998, p.50).
\end{abstract}

Ademais, comungamos com Pimenta (1998) ao escrever sobre o papel do conhecimento e como este é encarado pela sociedade nessa teia de relações:

Conhecimento não se reduz a informação. Esta é um primeiro estágio daquele. Conhecer implica, em um segundo estágio, de trabalhar com as informações classificando-as, analisando-as e contextualizando-as. O terceiro estágio tem a ver com a inteligência, a consciência ou sabedoria. Inteligência tem a ver com a arte de vincular conhecimento de maneira útil e pertinente, isto é, de produzir novas formas de progresso e desenvolvimento. Consciência e sabedoria envolvem reflexão, isto é, capacidade de produzir novas formas de existência, de humanização. Eé nessa trama que se pode entender as relações entre conhecimento e poder (op. cit. p. 52). 
Tal contribuição nos remete a reflexão sobre como a escola tem se colocado como prestadora de serviço ao cidadão. Esta exerce sua função verdadeiramente quando possibilita uma formação integral, atuando como lócus de construção do conhecimento, envolvendo os atores sociais num processo de ação-reflexão-ação, possibilitando através das múltiplas linguagens e dos diversos saberes, uma aprendizagem significativa na qual, através da dialética, seja possível estabelecer relações entre o texto e o contexto.

Nesse sentido, cabe destacar uma das ideias de Freire (1997, p.74): "Sabemos que não é a educação que modela a sociedade, mas, ao contrário, a sociedade é que modela a educação segundo os interesses dos que detêm o poder". Portanto, é necessário resgatar a função social da escola no sentido de redesenhar seu papel como polo de produção de cultura e espaço democrático, no qual o estudante possa verdadeiramente formar-se para a autonomia e para o exercício pleno da cidadania.

O espaço da escola como lócus de produção de cultura, significa construir conhecimento além dos conteúdos historicamente acumulados, formando o cidadão para a inclusão social e não apenas para o mercado de trabalho, exige um esforço de todos os envolvidos com a educação, no sentido de considerar os aspectos que envolvem o cotidiano da escola e do estudante, desde as questões sociais, políticas e econômicas, perpassando pelos aspectos culturais e principalmente pela trama das relações existentes no interior da escola e seu entorno.

Para a escola exercer sua função social, deve ser pensada pelo conjunto dos atores envolvidos no processo, garantindo uma estreita relação entre teoria e prática, no sentido de buscar no processo ensino e aprendizagem uma articulação entre o senso comum e o conhecimento historicamente acumulado, com um ensino contextualizado que represente ao aluno não somente um ambiente para receber informações, mas especialmente para exercer seu poder de criação, que reflita numa aprendizagem significativa capaz de desenvolver seu pensamento crítico e reflexivo.

Sobre o pensamento crítico, Arroyo (1999) atesta:

O pensamento crítico toma como seu objeto os elementos constantes das estruturas, das instituições se dos processos globais, sociais, ideológicos e políticos, o que é legítimo e necessário para a compreensão dos fenômenos sociais, educacionais e culturais. Porém, essa mesma ênfase pode levar, e por vezes tem levado, à marginalização da concretude da prática social e educativa". (ARROYO, 1999, p. 144).

Nesses termos, faz-se necessário compreender as relações sociais existentes no interior da escola para que se possa verdadeiramente formar cidadãos críticos e conscientes de seu papel na sociedade. Paro (2001) chama a atenção para esta questão ao afirmar:

Com respeito às relações sociais escolares, ou às características sociais e políticas que assumem as práticas no interior da escola é preciso não 
ignorar, ao se refletir sobre políticas educacionais, que, embora produtos de determinações sociais mais amplas, as práticas escolares não deixam de ser configuradas também por condicionantes mais próximos e imediatos que não podem ser apreendidos sem se considerar a realidade concreta onde elas se manifestam (PARO, 2001, p.33).

Diante do exposto, é possível compreender que a relação pedagógica no interior da escola é de fundamental importância, sem a qual, o processo de ensino e aprendizagem fica fragmentado. Afinal, não se aprende de qualquer forma, sem uma ação reflexiva e sem a relação dialética. Não se aprende na perspectiva de construção da autonomia, sem apropriação do caminho que está trilhando, e cada sujeito trilha o seu caminho em ritmo distinto. Portanto, é necessário compreender os ritmos e espaços escolares de cada um, para que a escola assuma verdadeiramente sua função social.

Sendo assim, o grande desafio da escola em sua função social é possibilitar que as oportunidades educacionais sejam democratizadas de forma a contemplar toda a clientela, no sentido de formar para a cidadania, para a vida e para a inclusão social.

\section{CONSIDERAÇÕES FINAIS}

Foi assinalado no início deste trabalho que a preocupação fundamental seria a de analisar e entender o papel da educação na formação do cidadão para inclusão social em São Paulo a partir de 1980. A pesquisa propiciou uma série de reflexões que serão sucintamente elencadas nestas considerações finais.

Atualmente, o Sistema Educacional Brasileiro convive com o drama do analfabetismo, pois alunos que concluem o Ensino Fundamental, em sua grande maioria, saem pouco escolarizados. Muitas vezes, terminam o Ensino Médio sem saber ler e escrever corretamente.

Ademais, estamos vivendo a sociedade tecnológica calcada no conhecimento, ou simplesmente a sociedade do conhecimento. Portanto, faz-se necessário equipar o cidadão dos conhecimentos necessários para ocupação na atividade laborativa.

É neste universo que o discente vivencia situações diversificadas, favorecendo o aprendizado, para que ele possa aprender a aprender. Por muito tempo, a pedagogia focou o processo de ensino no professor, supondo que, como decorrência, estaria valorizando o conhecimento. O ensino, então, ganhou autonomia em relação à aprendizagem, criou seus próprios métodos e o processo de aprendizagem ficou relegado em segundo plano. Hoje é sabido que é preciso ressignificar a unidade entre aprendizagem e ensino, uma vez que, em última instância, sem aprendizagem o ensino não se consuma. 
Nesse sentido, é preciso repensar a formação permanente dos educadores, para acabar com a dicotomia discurso e prática. Por fim, cabe ressaltar que a educação no Brasil sempre funcionou como aparelho ideológico do Estado e como instrumento de contenção e liberação das tensões sociais, expulsando as camadas mais pobres para fora do muro da escola.

Parece claro que a formação propiciada no contexto escolar tem um duplo enfoque. Primeiro, não se pode deixar de conhecer a realidade social da atualidade, dos atuais conteúdos trabalhados nas escolas, das exigências atuais em termos de avaliação do conhecimento construído. Tudo isso necessita continuar sendo trabalhado. Segundo, no entanto, mais do que ensinado, deve ser repensado, analisado, discutido e ressignificado. Com um olhar nas demandas atuais e em um futuro próximo, cabe então o enfoque no ensino voltado ao ensinar a pensar, à análise crítica e ao desenvolvimento das capacidades mentais.

Indiscutivelmente, os estudantes de hoje, profissionais de amanhã, encontrarão problemas, fatos, conceitos, que nem imaginamos. Assim, é viável prepará-los para as novas realidades que estão postas. Isso ocorrerá se a escola do presente trabalhar com uma visão de futuro. Propiciar aos estudantes a conquista da autonomia, que não pode ser apenas um discurso, mas a mola mestra que impulsiona sua ação pedagógica.

\section{REFERÊNCIAS}

ARROYO, Miguel Gonzales. Administração e qualidade da prática educativa: exigências e perspectivas. Revista Brasileira de Administração da Educação. Brasília, v. 12, n. 1, p. 9-22, jan./jun., 1996.

BRASIL. Constituição da República Federal do Brasil. 1988.

Ministério de Educação e do Desporto. Lei no 9.394/96 de 20/12/1996.

DOURADO, Luiz Fernandes. A Reforma do Estado e as Políticas de Formação de Professores nos anos 1990. In: Dourado, Luiz Fernandes; Paro, Vitor Henrique (Orgs.). Políticas Públicas \& Educação Básica. São Paulo: Xamã, 2001.

FREIRE, Paulo. Política e Educação. São Paulo: Cortez, 1997.

FRIGOTTO, Gaudêncio (Org.). Educação e Crise do Trabalho: perspectivas de final de século. Petrópolis: Vozes, 1998.

GRAMSCI, Antonio. Concepção Dialética da História. 2. ed. Rio de Janeiro: Civilização Brasileira, 1978a.

. Concepção Dialética da História. 3. ed. Rio de Janeiro: Civilização Brasileira, 1978b. 
GRECO, Milton. Caminhos para a construção de um Saber Plural. In: MEDINA, Cremilda; GRECO, M. (Orgs.). Agonia do Leviatã: a Crise do Estado Moderno. São Paulo: ECA/USP/CNPq, 1996.

NÓVOA, António (Org.). Vidas de Professores. Porto: Editora, 1992.

.(Coord.). As organizações escolares em análise. Lisboa: Dom Quixote, 1992.

OLIVEIRA, Dalila Andrade. Política Educacional nos Anos 1990: Educação Básica e Empregabilidade. In: Dourado, Luiz Fernandes; Paro, Vitor Henrique (Orgs.). Políticas Públicas \& Educação Básica. São Paulo: Xamã, 2001.

PARO, Vitor Henrique. Políticas Educacionais: Considerações sobre o discurso genérico e a abstração da realidade. In: Dourado, Luiz Fernandes; Paro, Vitor Henrique (Orgs.). Políticas Públicas \& Educação Básica. São Paulo: Xamã, 2001.

PIMENTA, Selma Garrido. Projeto Pedagógico e identidade da escola. Revista Educação e Formação, Taubaté, 1998. 


\author{
Rosana de Oliveira Sá ${ }^{1}$ \\ Linduarte Pereira Rodrigues ${ }^{2}$
}

\title{
RESUMO
}

O presente capítulo promove uma discussão teórica acerca do agir docente nas aulas de Língua Portuguesa, no que concerne ao ensino de produção textual, especificamente no contexto do PROEJA. Utilizou-se dos aportes teóricos da Linguística que se dedica ao ensino de língua materna (ANTUNES, 2009; MENDONÇA, 2006); dos estudos do letramento, baseados em Kleiman (2000; 2006); Rojo (2009); Oliveira, Tinoco e Santos (2014) e dos documentos oficiais que regulamentam o ensino de Língua Portuguesa no Ensino Médio. Metodologicamente, trata-se de uma pesquisa bibliográfica e documental, no intuito de disponibilizar orientações acerca da prática docente nessa modalidade de ensino. Os resultados revelam a relevância de projetos de letramento didáticos que valorizem práticas pedagógicas voltadas para a construção da cidadania e para as reais necessidades cotidianas e profissionais dos discentes da EJA.

Palavras-chave: Ensino de Língua Portuguesa. Produção Textual. PROEJA. Pedagogia de projetos.

\section{INTRODUÇÃO}

O presente capítulo tem como motivação inicial promover uma reflexão acerca do ensino de Língua Portuguesa na EJA Profissionalizante. Esta modalidade de ensino, inicialmente ofertada pela Rede Federal de Educação Profissional e Tecnológica, agrega três segmentos da educação: Educação Básica; Educação Profissional; e Educação de Jovens e Adultos. Os quais, individualmente, já são complexos campos de estudo por apresentarem seus próprios desafios e percalços, resultantes de constantes embates político-ideológicos.

Acerca das políticas da EJA, vale ressaltar que a EJA Profissionalizante foi estabelecida pelo Decreto $n^{\circ}$. 5.478, de 24 de junho de 2005. Sua criação foi uma decisão governamental proposta como alternativa para a formação de trabalhadores no Brasil. Tal medida promoveu a integração das modalidades de Educação de Jovens e Adultos (EJA) e Educação Profissional, visando, além da certificação técnica, à elevação da escolaridade. Em seguida, por meio do Decreto $n^{\circ} .5 .840$ de 13 de julho de 2006, foi ampliado em termos de abrangência e aprofundado em seus princípios pedagógicos, passando a se chamar oficialmente Programa Nacional de Integração da Educação Profissional com a Educação Básica na Modalidade de Educação de Jovens e Adultos (doravante PROEJA).

\footnotetext{
1 Mestra em Formação de Professores pela Universidade Estadual da Paraíba (PPGFP-UEPB). E-mail: rosana.sa@ifpb.edu.br

${ }^{2}$ Doutor em Linguística pela Universidade Federal da Paraíba (PROLING-UFPB). E-mail: linduartepr@gmail.com
} 
Na busca dessa integração entre o Ensino Fundamental e a formação inicial para o trabalho, como também na tentativa de implantação de uma nova concepção educacional, fez-se necessário definir alguns princípios ${ }^{3}$ para fundamentar o processo de ensino-aprendizagem do PROEJA: a) Princípio da aprendizagem e de conhecimentos significativos; b) Princípio de respeito ao ser e aos saberes dos educandos; c) Princípio de construção coletiva do conhecimento; d) Princípio da vinculação entre educação e trabalho: integração entre a Educação Básica e a Profissional e Tecnológica; e) Princípio da interdisciplinaridade; f) Princípio da avaliação como processo (BRASIL, 2007a, p. 29-30).

No tocante às mudanças nas leis que norteiam o ensino brasileiro, cabe destacar a Lei $n^{\circ}$ 13.632/2018 que alterou a Lei $\mathrm{n}^{\circ}$ 9.394/1996 (LDB), a fim de garantir, a todos, ensino formal e conhecimento por toda a vida. Na nova Lei, o Art.37 da Seção V - que trata da Educação de Jovens e Adultos - além de manter a determinação que essa modalidade "será destinada àqueles que não tiveram acesso ou continuidade de estudos nos ensinos fundamental e médio na idade própria", incluiu que "constituirá instrumento para a educação e a aprendizagem ao longo da vida". Alteração que assegura a Educação como um direito e uma necessidade fundamental humana; e que possibilita ao indivíduo adquirir saberes para se humanizar, emancipar, libertar (FREIRE, 2019).

Nesse contexto de políticas educacionais, é válido evidenciar as Conferências Internacionais de Educação de Adultos $^{4}$ e alguns documentos internacionais ${ }^{5}$, os quais promoveram mudanças nas políticas da Educação de Jovens e Adultos. Estas "apresentam como princípios norteadores a equidade, a diversidade, a inclusão e a qualidade social" (OLIVEIRA, 2015, p. 28). Além disso, a autora explica que a partir do momento em que a EJA tornou-se um direito do cidadão, "substituiu a ideia de suprimento e compensação da escolaridade perdida, pela reparação e equidade" (OLIVEIRA, 2015, p. 27). No entanto, percebemos que a efetivação dessas novas funções ainda desafia a EJA diariamente, uma vez que envolvem não apenas mudanças estruturais nos sistemas educacionais, mas também atitudinais, devido às constantes práticas discriminatórias que afetam jovens e adultos excluídos socialmente por motivos banais, como:

\footnotetext{
3 Para maiores esclarecimentos acerca das concepções e princípios que fundamentam a modalidade PROEJA, sugerimos a leitura, na íntegra, do capítulo 5 do Documento Base - Formação Inicial e Continuada / Ensino Fundamental (BRASIL, 2007a, p. 27-30).

${ }^{4}$ Entre muitas, ressaltamos as CONFINTEAS, realizadas em diferentes países a cada 12 anos: CONFINTEA I (Dinamarca- 1949); CONFINTEA II (Canadá-1963); CONFINTEA III (Japão, 1972); CONFINTEA IV (França 1985); CONFINTEA V (Alemanha -1997); CONFINTEA VI (Brasil, 2009). Encontros que objetivam debater e avaliar as políticas implementadas para a modalidade de educação de adultos, como também programar ações que viabilizem uma educação centrada no ser humano, baseada no respeito integral aos direitos humanos e ao ensino de qualidade.

${ }^{5}$ Destaque para a Declaração Universal dos Direitos Humanos (1948) e a Declaração Mundial sobre Educação para todos (1990), que objetivaram, principalmente, universalizar o direito à educação e mobilizar recursos para promover a equidade.
} 
condições financeiras; exclusão digital; religião; cultura; sexualidade; desvalorização das diversidades, dentre outros.

Diante disso, esta pesquisa é justificada pelo entendimento de que o processo de ensino e aprendizagem nas aulas de Língua Portuguesa do PROEJA, especificamente neste estudo, deve considerar as necessidades cotidianas do discente, oferecendo-lhe as condições de posicionamento diante do mundo, para exercer plenamente sua cidadania e entender o impacto social que um indivíduo pode causar através do bom uso da linguagem. Já que "é a prática social que viabiliza a exploração do gênero, e não o contrário" (KLEIMAN, 2006, p. 33). Ademais, esse ensino consciente deveria ser uma prática comum em ambientes escolares como o do PROEJA, com professores e alunos envolvidos no aprendizado e na produção de textos que realmente contribuam para o desenvolvimento social e intelectual de todos os atores envolvidos. Paradoxalmente, nos diversos contextos de ensino de língua materna vivenciados, enquanto docentes, essa não é uma prática corrente.

Sendo assim, este texto pretende figurar como uma discussão teórica acerca do agir docente nas aulas de produção textual do PROEJA, incentivando o ensino de produção textual a partir de gêneros textuais condizentes com os interesses profissionais e sociais dos discentes, como também ressaltando a pedagogia de projetos como uma possibilidade metodológica para essa modalidade de ensino.

Do ponto de vista teórico, ancoramos nosso estudo nos aportes da linguística contemporânea, com ênfase na linguística aplicada, nos estudos do letramento, assim como nos documentos oficiais que norteiam o ensino de Língua Portuguesa. Em relação à metodologia, desenhamos uma pesquisa de natureza bibliográfica e documental, visando disponibilizar orientações e motivar reflexões acerca de práticas docentes para essa modalidade específica.

Em suma, a relevância desta pesquisa se impõe pelo fato de: i) apresentar um panorama das regulamentações oficiais referentes ao processo de ensino de Língua Portuguesa no contexto do Ensino Médio, no qual a Educação de Jovens e Adultos Profissionalizante está inserida; ii) discutir as concepções de alguns estudiosos sobre o ensino da linguagem através de gêneros textuais em diferentes esferas de circulação; e iii) evidenciar concepções emergentes sobre projetos de letramento de inclusão social.

\section{DOCUMENTOS OFICIAIS E ENSINO DE LÍNGUA(GENS) NO PROEJA}

O ensino de Língua Portuguesa (doravante LP) no Brasil fundamentou-se, durante muito tempo, no ensino da gramática do português, baseado na concepção de que tão logo os alunos dominassem a classificação gramatical, estariam aptos a se inserir em práticas letradas. Ensinar a 
língua limitava-se quase que totalmente à perspectiva gramatical; e as poucas atividades de produção textual não eram contextualizadas - o que tornava tais práticas sem sentido e, muitas vezes, um fardo para alunos e professores.

Somente na década de 1980 é que se começa a pensar o ensino de LP não apenas como o ensino de sua estrutura, mas também como o ensino do uso dos diferentes gêneros textuais. Iniciou-se um movimento de crítica aos pressupostos de uma língua como instrumento comunicacional e centrada apenas na gramática. A proposta era priorizar o texto na sala de aula (GERALDI, 2011), isto é, um ensino voltado para a textualidade, tanto no eixo da leitura quanto no da produção. Essa nova perspectiva constituiu-se como um novo paradigma educacional. A partir de então, as concepções de discurso e enunciação passam a ser valorizadas no ensino de língua materna. A língua não é mais concebida apenas como instrumento de comunicação, mas como um espaço de interação.

A década de 90 foi marcada pela iniciativa governamental na implantação de um novo modelo de ensino no país, através da aprovação da Lei de Diretrizes e Bases e da criação dos Parâmetros Curriculares Nacionais. Os PCN de LP sofrem influência dos estudos críticos do letramento Kleiman (1995); Kleiman e Moraes (1999), bem como dos estudos sobre gêneros textuais, os quais enfocam a relação entre os textos e seu funcionamento em práticas sociais situadas.

Como a linguagem está presente nas mais variadas práticas sociais, seu domínio possibilita uma maior inserção social, visto que os indivíduos acessam informação, trocam conhecimentos e defendem seus pontos de vista por meio dela. Desta forma, ao ensinar LP, a escola assume para si a responsabilidade de contribuir para assegurar aos seus alunos o acesso aos saberes da fala e da escrita, necessários para que cada um seja capaz de interpretar e produzir textos em diversas situações cotidianas. Nessa perspectiva, os PCN de Linguagens, Códigos e suas Tecnologias constituem-se uma referência para contribuir com técnicas e sugestões para professores no processo de elaboração de seus planos de ensino. Sobre o ensino de língua materna, os PCN+ (BRASIL, 2002, p. 55) atestam:

[...] o ensino de língua portuguesa, hoje, busca desenvolver no aluno seu potencial crítico, sua percepção das múltiplas possibilidades de expressão linguística, sua capacitação como leitor efetivo dos mais diversos textos representativos de nossa cultura. Para além da memorização mecânica de regras gramaticais ou das características de determinado movimento literário, o aluno deve ter meios para ampliar e articular conhecimentos e competências que possam ser mobilizados nas inúmeras situações de uso da língua com que se depara, na família, entre amigos, na escola, no mundo do trabalho. 
Os PCN+ definem, pois, que o aluno egresso do Ensino Médio deverá ter garantido o conhecimento sobre as diversas manifestações da linguagem verbal, de modo a posicionar-se em relação a elas, compreendê-las, aplicá-las e/ou transformá-las. Visto que "a principal razão de qualquer ato de linguagem é a produção de sentido" (BRASIL, 2002, p. 25).

Ademais, é proposto nas Orientações Curriculares para o Ensino Médio (OCEM) que o Ensino Médio assegure aos discentes "a preparação básica para o prosseguimento dos estudos, para a inserção no mundo do trabalho e para o exercício cotidiano da cidadania, em sintonia com as necessidades político-sociais de seu tempo" (BRASIL, 2006, p. 18). Já as práticas realizadas nas aulas de LP “devem propiciar ao aluno o refinamento de habilidades de leitura e de escrita, de fala e de escuta" (op. cit., p.18). Atitudes que ampliam os saberes acerca da organização e funcionalidade dos textos, como também propiciam uma constante reflexão acerca da linguagem.

Nessa perspectiva, o ensino e aprendizagem de LP devem abordar a leitura, a produção de texto e a análise linguística, privilegiando diferentes gêneros textuais selecionados a partir da necessidade de uso nas nossas transações sociais cotidianas. A gramática da língua deve ser "uma gramática mais próxima das operações que as pessoas realizam quando usam a língua em situações concretas de comunicação" (ANTUNES, 2009, p. 214). Segundo Mendonça (2006, p. 208), o trabalho de análise linguística deve ser configurado a partir de:

[...] reflexão recorrente e organizada, voltada para a produção de sentidos e/ou para a compreensão mais ampla dos usos e do sistema linguístico, com o fim de contribuir para a formação de leitores-escritores de gêneros diversos, aptos a participarem de eventos de letramento com autonomia e eficiência.

Contudo, para que se alcancem os objetivos propostos nesses estudos/documentos, faz-se necessário que o processo de ensino e aprendizagem de leitura e produção textual seja previamente planejado por docentes aptos a articular esses conhecimentos e inseri-los em suas práticas pedagógicas.

No que tange à Educação de Jovens e Adultos, em especial ao PROEJA, o Documento Base (BRASIL, 2007b) atestou que essa modalidade de ensino caracteriza-se por atender a um grupo composto, basicamente, por trabalhadores com experiências escolares marcadas por períodos de afastamento e por reprovações. Portanto, os conhecimentos de leitura e de produção textual dos sujeitos do PROEJA não se constroem, exclusivamente, pela escolarização, mas também por saberes que vêm de outros contextos, das interações sociais e das diversificadas experiências pessoais e profissionais. Por isso, é viável a inserção de práticas de letramento no processo de ensino e aprendizagem desses educandos. 
As contribuições dos estudos do letramento têm grande relevância para dar suporte aos planejamentos e práticas linguísticas destinadas aos discentes do PROEJA, pois são alunos que representam um grupo que reingressa à escola para realizar uma formação profissional e, consequentemente, para ampliar os conhecimentos e circular com autonomia como cidadãos.

Nesse contexto, convém mencionar que, se pretendemos educar para o pleno exercício da cidadania, precisamos reconfigurar as práticas de letramento desenvolvidas na sala de aula, alinhando-as às necessidades cotidianas dos discentes e desenvolvendo-as na perspectiva das práticas sociais, visando romper definitivamente com o modo descontextualizado de ensinar, ainda vigente em muitas instituições de ensino. Acerca dessa necessidade, Kleiman e Moraes (1999, p. 191) atestam que "Para fazer frente a uma sociedade injusta e desigual é preciso formar indivíduos plenamente letrados, que possam seguir aprendendo pelo resto de suas vidas, capazes de utilizar a escrita para se fazerem ouvir, resistirem à propaganda, à mídia, atualizarem-se e serem críticos".

Isso implica dizer que o ensino voltado para práticas de letramento que incentivam a vivência da cidadania, minimiza os efeitos das desigualdades sociais. Acerca das concepções de linguagem e das práticas de ensino com letramentos múltiplos, as Orientações Curriculares para o Ensino Médio enfatizam:

A lógica de uma proposta de ensino e de aprendizagem que busque promover letramentos múltiplos pressupõe conceber a leitura e a escrita como ferramentas de empoderamento e inclusão social. Some-se a isso que as práticas de linguagem a serem tomadas no espaço da escola não se restringem à palavra escrita nem se filiam apenas aos padrões socioculturais hegemônicos (BRASIL, 2006, p. 28).

Entendemos que o professor tem a opção de ressignificar as práticas de linguagem dentro do contexto das comunidades em que a escola está incluída através de textos que melhor reproduzam a realidade dos educandos. Tal atitude possibilitará aos alunos uma conscientização não apenas da própria condição, mas também da comunidade na qual estão inseridos, auxiliandoos, assim, a atuarem como protagonistas (BRASIL, 2000; 2002; 2013) na ação coletiva e na realização de seus sonhos profissionais e pessoais.

\section{GÊNEROS TEXTUAIS NA AULA DE LÍNGUA PORTUGUESA}

Ao revisarmos a literatura acerca do estudo de gêneros, constatamos que a palavra "gênero", por muito tempo, esteve ligada à tradição ocidental, principalmente relacionada aos gêneros literários. "Tendo em Platão a tradição poética e em Aristóteles a tradição retórica" (MARCUSCHI, 2008, p. 152). Na atualidade, o estudo de gêneros textuais é visto de forma inter/pluridisciplinar e, constantemente, há novas investigações e posicionamentos para o 
tratamento dos gêneros. Mesmo entre os estudiosos e linguistas, há divergências relacionadas a conceitos terminológicos, sendo estes vinculados à perspectiva e à orientação teórica dos grupos de estudos. Alguns teóricos utilizam o termo "gêneros discursivos" a exemplo de Bakhtin/Medvedev (2006); outros utilizam "gêneros textuais", como Bronckart (1999), Dolz e Schneuwly (2004), Marcuschi (2003; 2008), dentre outros ${ }^{6}$.

Independente das diferentes denominações, a ideia de que toda comunicação verbal só é possível pela mediação de um gênero textual - cuja materialidade é o texto - é defendida por Bronckart (1999); Bakhtin/Medvedev (2006), e também pela maioria dos especialistas que tratam a língua em seus aspectos discursivos e enunciativos, privilegiando a natureza interativa da língua, conforme explica Marcuschi (2003).

Apesar de os estudos apresentarem diferentes perspectivas, eles têm um ponto em comum: o reconhecimento do aspecto social e o papel do contexto e sua funcionalidade para a compreensão e identificação do gênero textual. Essa noção, de compreender os gêneros textuais levando em consideração os aspectos sociais, rompe com as concepções de língua embasadas pela Gramática Tradicional e pelas abordagens estruturalistas.

Bathia (1997 apud MARCUSCHI, 2008) aponta que os gêneros textuais permitem responder o porquê das pessoas usarem a língua da maneira como o fazem, uma vez que eles têm uma forma e uma função, bem como um estilo e um conteúdo. Contudo, sua função deve predominar sobre a forma para sua identificação. Marcuschi (2008) destaca que os gêneros se definem/caracterizam principalmente por seus aspectos sociocomunicativos e funcionais. Para Marcuschi (2008, p. 155),

Os gêneros textuais são os textos que encontramos em nossa vida diária e que apresentam padrões sociocomunicativos característicos definidos por composições funcionais, objetivos enunciativos e estilos concretamente realizados na integração de forças históricas, sociais, institucionais e técnicas.

Dolz e Schneuwly (2004) compreendem que os gêneros textuais podem ser usados como instrumentos no ensino e aprendizagem. Para eles, a situação interacional é a responsável pela determinação de qual gênero será utilizado, o que leva os autores a comprovar sua tese de que o gênero é um instrumento que media a relação entre sujeito e linguagem.

Dentre as perspectivas teóricas desenvolvidas sobre os gêneros textuais, uma das teorias que se volta, primordialmente, para as questões do ensino de língua materna é a perspectiva

\footnotetext{
${ }^{6}$ Não cabe neste estudo discutirmos qual denominação "gênero textual" ou "gênero discursivo" é a mais apropriada. No entanto, para manter certa uniformidade de terminologia, optamos pela expressão gêneros textuais, conforme sugere Marcuschi $(2003 ; 2008)$.
} 
adotada pelos representantes da Escola de Genebra: Dolz, Schneuwly (2004); Jean-Paul Bronckart (1999; 2006). Esses teóricos se apoiam na teoria sociointeracionista da aprendizagem de origem vygotiskiana, de caráter psicológico e linguístico-filosófico, seguindo uma teoria metodológica definida por Bronckart $(1999 ; 2006)$ como interacionismo sociodiscursivo (ISD), que propõe um trabalho de investigação com as práticas de linguagens que são efetivadas a partir dos textos/gêneros presentes na sociedade. Já que "a apropriação dos gêneros é um mecanismo fundamental de socialização, de inserção prática nas atividades comunicativas humanas" (BRONCKART, 1999 apud MARCUSCHI 2008, p.154).

A partir dessas premissas, e considerando que na nossa vida sempre tentamos agir em relação ao outro, passamos a observar que tudo o que lemos e escrevemos pode ser usado em benefício de nossas práticas sociais cotidianas, com o propósito de atingir um determinado objetivo/objeto. Assim, todos os gêneros textuais que utilizamos no nosso dia a dia - como uma lista de compras, um convite, um panfleto etc. - passam a fazer parte de um conjunto de artefatos socio-históricos, dos quais lançamos mão quando necessitamos produzir uma determinada ação. Deles, podem se valer os docentes em suas práticas pedagógicas, a fim de produzirem situações semelhantes àquelas corriqueiras, no intuito de orientar o aluno a fazer uso da linguagem para alcançar determinados objetivos em sua vida, concedendo-lhe oportunidades de agir como sujeito consciente das relações das quais ele participa.

Vale ressaltar que existe uma recorrente preocupação sobre quais gêneros textuais incluir nas aulas de línguas. No entanto, o uso de gêneros textuais não deveria se restringir às aulas de língua materna no contexto escolar, mas ultrapassar as barreiras das disciplinas, para que os conteúdos curriculares pudessem dialogar mais uns com os outros. Sabendo que o gênero textual é um artefato que emoldura situações linguísticas da vida cotidiana dos sujeitos de uma comunidade, os docentes deveriam executar uma prática pedagógica na qual o uso de gêneros variados - como um instrumento de sociabilização - rendesse efeitos mais imediatos, do ponto de vista de uma produção textual centrada na relevância para a vida do aluno.

Ainda que os professores atestem a relevância do trabalho com gêneros em sala para o desenvolvimento da competência leitora e receptora, na prática, eles geralmente não conseguem fazer a movimentação de saberes necessários à formação de leitores e produtores de textos. Com isso, acabam trabalhando apenas "sobre" os aspectos estruturais dos gêneros, e não "com" eles como deveria ser. Segundo Rodrigues (2016), falta-lhes o desenvolvimento de uma práxis com foco no uso de gêneros textuais para o efetivo uso do texto como prática social. E acrescenta: 
prática social, o texto é sem dúvida meio e foco para a aula de língua portuguesa. Esta inclusão do texto, consequentemente do discurso e do sujeito que opera sentidos frente aos usos da linguagem põe por terra $o$ foco exclusivo na língua, considerada autossuficiente, como sustentava a Linguística Estrutural. Creio que situar o sujeito no centro das reflexões linguísticas significa hoje em dia voltar-se para o exterior da língua, para a produção sócio-histórico-cultural do texto e a atualização dos discursos que operam sentidos ideologicamente situados pela historicidade da palavra na sociedade e na cultura (RODRIGUES, 2016, p. 169-170).

Os instrumentos de políticas educacionais e linguísticas - como os PCNEM (BRASIL, 2000), PCN+ (BRASIL, 2002) - ressaltam que a atividade de escrever pode se tornar mais difícil se os textos escolhidos para o trabalho em sala de aula não forem genuínos, como também se os interlocutores com os quais esses textos dialogam forem mera ficção. Portanto, assumimos, neste estudo, que os documentos oficiais instituem uma boa prática pedagógica, uma vez que orientam o docente a fazer uso de textos autênticos, não apenas do ponto de vista de sua materialidade, mas, sobretudo, pela significação sociocultural e/ou profissional para o discente.

É justamente sobre o trabalho com práticas de ensino condizentes com a realidade alémmuro escolar dos discentes, construção coletiva do conhecimento e protagonismo do aluno, que falaremos na seção seguinte.

\section{PEDAGOGIA DE PROJETOS}

Ao refletirmos acerca das metodologias de ensino de LP, a partir da Linguística Aplicada, destacamos os projetos como instrumentos facilitadores da aprendizagem. Visto que tal prática, nas aulas de língua, ativa a dimensão sociocomunicativa da linguagem, como também se articula às noções de letramentos, gêneros e interdisciplinaridade, as quais vão direcionar uma metodologia de ensino voltada para práticas linguageiras (BRONCKART, 2006) que se desenvolvem em contextos situados, dinâmicos, em meio a trocas interativas nas quais os interlocutores, o tema, o propósito e a situação comunicativa desempenham um papel fundamental.

Letramento e gêneros textuais são conceitos relevantes para o entendimento do uso da linguagem como prática social, assim como sua relação com o desenvolvimento de projetos e com a noção de interdisciplinaridade. Rojo (2009, p. 11) enfatiza que um dos papéis da escola no mundo atual é possibilitar que os discentes "participem das várias práticas sociais que se utilizam da leitura e da escrita (letramentos) na vida da cidade, de maneira ética, crítica e democrática". Segundo a autora, para que isso aconteça, é necessário que a educação linguística trabalhe: i) os multiletramentos, valorizando não apenas os letramentos estimados universalmente, mas também 
os letramentos das culturas locais; ii) os letramentos multissemióticos, trabalhando a leitura e produção textual em diversas linguagens (verbal oral e escrita, musical, imagética etc.), isto é, outras semioses que não somente a escrita; iii) letramentos críticos, desvelando as reais intenções, finalidades e ideologias presentes nos textos (ROJO, 2009, p. 119-120).

Em seus estudos acerca do trabalho com projetos no campo da educação, Oliveira, Tinoco e Santos (2014, p. 12) levantaram o seguinte questionamento: "como trabalhar a linguagem, tendo por situação orientadora a relação exclusão/inclusão e os fundamentos de uma abordagem aberta de educação"? Em resposta à questão, indicaram os projetos de letramento ${ }^{7}$ como melhor saída para área de ensino de línguas, por entenderem a importância de trabalhar a leitura e a produção textual "como ferramentas para a agência social, garantindo a mudança, a emancipação e a autonomia, requisitos indispensáveis para o exercício da cidadania" (op. cit., p.13). Resposta que valida o conceito de projeto de letramento proposto por Kleiman (2000, p. 238):

[...] um conjunto de atividades que se origina de um interesse real na vida dos alunos e cuja realização envolve o uso da escrita, isto é, a leitura de textos que, de fato, circulam na sociedade e a produção de textos que serão realmente lidos, em um trabalho coletivo de alunos e professor, cada um segundo sua capacidade.

O elemento desencadeador de um projeto pode ser uma questão problema, que emerge do contexto em que os sujeitos que dele participam estão situados; do projeto político-pedagógico da escola e da disciplina (SUASSUNA; MELO; COELHO, 2006); ou pode ser guiado por temas geradores que sirvam como eixo orientador e estímulo para os sujeitos que dele participam. No entanto, é importante que a escolha desses temas parta de um consenso coletivo que propicie o entrosamento e engajamento de todo o grupo participante.

No tocante às vantagens de lecionar via projetos didáticos, destacamos o rompimento com o ensino pouco interativo e caracterizado pela prescrição, como também a possibilidade de tratar os conteúdos de modo articulado e contextualizado. Oliveira, Tinoco e Santos (2014, p.58) alertam que tal prática requer o rompimento com: i) a fragmentação dos conteúdos determinados nas grades curriculares; ii) o protagonismo do professor nas aulas de linguagem; iii) o ensino centrado em conteúdos gramaticais; e iv) as avaliações voltadas exclusivamente para o processo de assimilação da informação gramatical recebida na sala de aula.

Por outro lado, esse modo de ensinar demanda que o trabalho com a linguagem exerça variadas funções: i) didática, devido à necessidade de procurar recursos para atender a

\footnotetext{
${ }^{7}$ Oliveira, Tinoco e Santos (2014, p. 62) explicam que, ao longo do processo socio-histórico dos projetos, foram dadas diferentes adjetivações, reveladoras do viés pelo qual o pesquisador pretende investir: projeto temático, didático, educativo, pedagógico, projeto de letramento, de aula, de ensino, de conhecimento, de trabalho, de ação social, entre outras.
} 
necessidades comunicativas; ii) terapêutica, por motivar o aluno para a aprendizagem significativa da língua, cuidando de suas dificuldades e promovendo avanços; iii) social e de mediação, por compreender a linguagem como uma forma de abertura ao outro e como um recurso de mediação; iv) política, no sentido de utilizar a linguagem como forma de construir valores no cidadão (aluno) inerentes à cidadania; v) de produção, por entender a linguagem não apenas como um modo de expressão, mas também como forma de produção por meio da qual interferimos na realidade social (OLIVEIRA; TINOCO; SANTOS, 2014, p. 58).

Além disso, o desenvolvimento de projetos se configura como uma opção viável para abordar a linguagem de maneira colaborativa e interdisciplinar. Ações de ensino dessa natureza podem facilitar as atividades cotidianas dos discentes da EJA, uma vez que oportunizam o pleno exercício da cidadania.

Diante disso, entendemos que trabalhar considerando a realidade e as concepções de mundo desses alunos, mais do que uma escolha metodológica, é garantir aos alunos o que está prescrito no Documento Base do PROEJA:

Utilizando os conhecimentos dos alunos, construídos em suas vivências dentro e fora da escola e em diferentes situações de vida, pode-se desenvolver uma prática conectada com situações singulares, visando conduzi-los, progressivamente, a situações de aprendizagem que exigirão reflexões cada vez mais complexas e diferenciadas para identificação de respostas, re-elaboração de concepções e construção de conhecimentos (BRASIL, 2007a, p. 39).

Assim como valorizamos o conhecimento de mundo dos discentes de outras modalidades de ensino desde a Educação Infantil, os conhecimentos dos alunos do PROEJA também podem ser valorizados e desenvolvidos a partir de saberes que eles adquiriram fora da comunidade escolar em suas interações sociais e profissionais. Assim sendo, o professor da EJA pode fazer uso do conhecimento que esses educandos obtiveram naturalmente, a fim de utilizá-lo como diferencial facilitador do processo de ensino e aprendizagem.

\section{CONSIDERAÇÕES FINAIS}

Neste estudo, situamos o texto como elemento central no processo de ensino e aprendizagem de língua materna, evidenciamos o papel da linguagem como elemento facilitador de práticas sociais e trabalhamos na perspectiva do letramento como fenômeno plural, crítico, capaz de desencadear ações que beneficiem os discentes da EJA em suas atividades sociais e profissionais além dos muros escolares.

Além disso, ressaltamos que o processo de ensino de produção textual via projetos didáticos pode proporcionar uma maior interação entre docentes e discentes em sala, como 
também incentivar ao protagonismo por parte dos alunos. Uma vez que os projetos didáticos podem funcionar como uma maneira de organizar os conhecimentos escolares, de forma flexível e adaptável, de acordo com as especificidades dos discentes e /ou da turma como um todo.

Os estudos elencados neste capítulo também revelam que não há mais espaço para uma “escrita vazia, de palavras soltas, de frases soltas, de frases inventadas" (ANTUNES, 2003, p.115), já que esse tipo de prática não condiz com o mundo real dos discentes, principalmente os do PROEJA, por serem adultos que já participam de práticas sociais e/ou profissionais reais fora do ambiente educacional frequentemente.

Diante disso, é necessário que a prática do professor, as necessidades, os interesses dos alunos e o currículo escolar estejam em consonância, objetivando um processo de ensino e aprendizagem significativo. Contudo, para iniciar esse tipo de prática pedagógica é necessário, primeiramente, um (re)posicionamento identitário do docente e das escolhas teóricometodológicas feitas por ele, a fim de promover uma melhor articulação entre teoria e prática. Para tanto, a formação continuada de docentes parece ser um caminho para diminuir a discrepância entre teoria e prática que ainda permeia nosso cenário escolar, principalmente para aqueles que atuam nas Instituições de Ensino Médio Profissionalizante da EJA, uma vez que não há licenciatura que forme para essa modalidade de ensino específica.

Sendo assim, faz-se necessário que as políticas públicas e as instâncias educacionais invistam na formação inicial e continuada dos profissionais dessa modalidade peculiar de ensino, visto que é através do conhecimento das especificidades dessa comunidade escolar que docentes e gestores poderão contribuir para a formação social e profissional de Jovens e Adultos.

Por fim, a partir das orientações dos documentos oficiais sobre o trabalho com textos e das reflexões/sugestões aqui apresentadas, esperamos fomentar pesquisas que evidenciem ações pedagógicas para o ensino de Língua Portuguesa no contexto escolar do PROEJA, especialmente, uma vez que é uma modalidade ainda carente de recursos didáticos e de práticas escolares que promovam um aprendizado mais condizente com as demandas profissionais futuras desse alunado.

\section{REFERÊNCIAS}

ANTUNES, Irandé. Aula de português: encontro \& interação. São Paulo: Parábola, 2003.

Língua, texto e ensino: outra escola possível. São Paulo: Parábola, 2009.

BAKHTIN, Mikhail (MEDVEDEV). Os Gêneros do discurso. In: A Estética da Criação

Verbal. São Paulo: Martins Fontes, 2006. [1979] p. 261 - 421. 
BRASIL. Lei de Diretrizes e Bases da Educação Nacional - LDBEN (Lei no 9.394/96). Brasília, 20 de dezembro de 1996.

. Ministério da Educação. Secretaria da Educação Média e Tecnológica. Parâmetros Curriculares Nacionais Ensino Médio. Brasília: MEC, 2000.

. Ministério da Educação. Secretaria de Ensino Médio e Tecnológico. PCN+ Ensino Médio - Orientações Educacionais Complementares aos Parâmetros Curriculares Nacionais: linguagens, códigos e suas tecnologias. Brasília: MEC, 2002.

Ministério da Educação. Secretaria de Educação Básica. Conhecimentos de língua portuguesa. Orientações Curriculares para o Ensino Médio: linguagens, códigos e suas tecnologias. Brasília: MEC, 2006.

Ministério da Educação. PROEJA: Programa Nacional de Integração da Educação Profissional com a Educação Básica na Modalidade de Educação de Jovens e Adultos: Documento Base - Formação inicial e continuada/ Ensino Fundamental. Brasília, DF: MEC, 2007a.

Ministério da Educação. Educação Profissional Técnica de Nível Médio Integrada ao Ensino Médio. Documento Base. Brasília, DF: MEC, 2007b.

Ministério da Educação. Secretaria de Educação Básica. Diretoria de Currículos e Educação Integral. Diretrizes Curriculares Nacionais da Educação Básica. Brasília: MEC, SEB, DICEI, 2013.

BRONCKART, Jean-Paul. Atividade de linguagem, textos e discursos: por um interacionismo sócio-discursivo. São Paulo: Editora da PUC-SP EDUC, 1999.

DOLZ, Joaquim; SCHNEUWLY, Bernard. Gêneros orais e escritos na escola. Campinas, SP: Mercado de Letras, 2004.

FREIRE, Paulo. Pedagogia do oprimido. 67. ed. RJ/SP: Paz e Terra, 2019.

GERALDI, J. W. (Org.). O texto na sala de aula. 5. ed. São Paulo: Ática, 2011.

KLEIMAN, Angela B. Os significados do letramento: uma perspectiva sobre a prática social da escrita. Campinas, SP: Mercado de Letras. 1995.

; MORAES, S. E. Leitura e interdisciplinaridade: tecendo redes no projeto da escola. Campinas, SP: Mercado de Letras, 1999.

O processo de aculturação pela escrita: ensino da forma ou aprendizagem da função? In: KLEIMAN, Angela B.; SIGNIORINI, Inês (Orgs.). O ensino e a formação do professor: alfabetização de jovens e adultos. Porto Alegre: Artmed, 2000.

Leitura e prática social no desenvolvimento de competências no ensino médio. In: BUNZEN, Clécio; MENDONÇA, Márcia (Orgs). Português no Ensino Médio e formação de professor. São Paulo: Parábola, 2006, p.23-36. 
MARCUSCHI, L. A. Gêneros textuais: definições e funcionalidade. In: DIONÍSIO, A. P.; MACHADO, A. R.; BEZERRA, M. A. (Orgs.). Gêneros textuais \& ensino. 2. ed. Rio de Janeiro: Lucerna, 2003, p. 19-36.

MARCUSCHI, L. A. Produção textual, análise de gêneros e compreensão. São Paulo: Parábola Editorial, 2008.

MENDONÇA, Márcia. Análise linguística no ensino médio: um novo olhar, um novo objeto. In: BUNZEN, Clécio; MENDONÇA, Márcia (Orgs.). Português no Ensino Médio e formação de professor. São Paulo: Parábola, 2006, p. 199-226.

OLIVEIRA, Ivanilde Apoluceno de O. As políticas de Educação de Jovens e Adultos no século XXI: diretrizes dos documentos demarcatórios em curso. In: BARCELOS, Valdo; DANTAS, Tânia Regina (Orgs.). Políticas e Práticas na Educação de Jovens e Adultos. Petrópolis-RJ: Vozes, 2015.

OLIVEIRA, Maria do S.; TINOCO, Glícia A.; SANTOS, Ivoneide B. de A. Projetos de letramento e formAÇÃO de professores de língua materna. Natal: EDUFRN, 2014.

ROJO, R. Letramentos múltiplos, escola e inclusão social. São Paulo: Parábola, 2009.

RODRIGUES, Linduarte Pereira. Folhetos de cordel no ensino de língua materna: aspectos culturais e formação docente. Revista do Gelne. Natal, RN: 2016, p.140-167.

SUASSUNA, Lívia; MELO, Iran F. de; COELHO, Wanderley Elias. O projeto didático: forma de articulação entre leitura, literatura, produção de texto e análise linguística. In: BUNZEN, Clécio; MENDONÇA, Márcia (Orgs.). Português no Ensino Médio e formação de professor. São Paulo: Parábola, 2006, p. 227-244. 


\title{
https://doi.org/10.36470/famen.2020.14c16 \\ OS INSTITUTOS FEDERAIS E O DIREITO À EDUCAÇÃO ESPECIAL NO ENSINO SUPERIOR
}

\author{
Andrezza M. B. do N. Tavares ${ }^{1}$ \\ Breno Trajano de Almeida ${ }^{2}$
}

\section{RESUMO}

A configuração da educação especial no ensino superior é direcionada à perspectiva inclusiva. Este trabalho atentou para um estudo exploratório e descritivo dos Planos de Desenvolvimento Institucional dos Institutos Federais de Educação, Ciência e Tecnologia na perspectiva do direito à educação para pessoas com deficiência, incluindo análise das ações relativas à diferenciação curricular e condições de acessibilidade física, pedagógica, estrutural e de materiais/recursos, possibilitando agregar informações importantes e significativas sobre inclusão dos estudantes com deficiência. A partir das análises foi possível depreender que, apesar dos avanços na consignação da Educação Especial como direito e modalidade específica, muitas das suas indispensáveis adequações ainda configuram como intencionalidade, especialmente no ensino superior.

Palavras-chave: Educação Especial. Institutos Federais. Inclusão. Ensino Superior.

\section{INTRODUÇÃO}

É na Idade Moderna que começam os primeiros métodos de comunicação e educação para pessoas surdas, contrariando o senso comum da época de que essas pessoas não podiam ser escolarizadas. No século XIX, surge a escrita Braille, que permite a escolarização de cegos. É também o período em que as primeiras percepções sobre as necessidades das pessoas com deficiência passam a ser reconhecidas e analisadas no mundo todo.

No século XX, a humanidade assolada por diversas guerras, sendo duas mundiais, se viu impelida não apenas a reconstruir-se, como a tratar, reabilitar e incluir os milhares de feridos e mutilados, surgindo então, entidades voltadas às pessoas com deficiência. De acordo com Marcelino (2013), em 1962 inicia-se nos Estados Unidos o movimento pelos direitos das pessoas com deficiência, com a criação do $1^{\circ}$ Centro de Vida Independente no Mundo.

Para SASSAKI (1999, p.41), a inclusão é "um processo pelo qual a sociedade se adapta para poder incluir em seus sistemas sociais gerais", capacitando a pessoa com deficiência para assumir seus papéis na sociedade.

\section{A EDUCAÇÃO ESPECIAL NO BRASIL}

No Brasil, segundo Mazzotta (2005, p.28-29), o Imperador Dom Pedro II (1840-1889), criou o Imperial Instituto dos Meninos Cegos, atualmente Instituto Benjamin Constant, por meio

\footnotetext{
${ }^{1}$ Doutora em Educação pela Universidade Federal do Rio Grande do Norte. E-mail: andrezza.tavares@ifrn.edu.br ${ }^{2}$ Mestre em Educação pela Universidade de São Paulo (USP). E-mail: breno.almeida@ifrn.edu.br
} 
do Decreto Imperial n ${ }^{\circ}$ 1.428, de 12 de Setembro de 1854 e, em 26 de setembro de 1857, fundou o Imperial Instituto de Surdos Mudos, atualmente Instituto Nacional de Educação de Surdos INES. Mas, somente em 1890, no primeiro Censo da República, é que são incluídas informações sobre deficiência, ao pesquisar por: nome, sexo, idade, estado civil, cor, filiação, naturalidade, nacionalidade dos pais, defeitos físicos e residência (IBGE 2003).

A Lei Brasileira de Inclusão da Pessoa com Deficiência (Estatuto da Pessoa com Deficiência-PCD), Lei $\mathrm{n}^{\circ}$ 13.146, de 06 de julho de 2015, indicou quais direitos deveriam ser garantidos às pessoas com deficiência de modo geral e aos estudantes com deficiência e com altas habilidades. Cabe destacar que a Lei incluiu as instituições privadas de ensino nessa obrigatoriedade (art. 28, parágrafo $1^{\circ}$ ), encerrando de uma vez por todas as possibilidades de negar matrícula a pessoa com deficiência, sob o argumento de que a obrigatoriedade era só das escolas públicas.

Com a substituição da Política Nacional de Educação Especial pela Política Nacional de Educação Especial na Perspectiva da Educação Inclusiva (2008), o objetivo passou a ser a inclusão escolar de alunos com deficiência, transtornos globais do desenvolvimento e altas habilidades/superdotação da Educação Infantil ao ensino Superior.

O Censo INEP 2018 registra que 1.224.909 pessoas com deficiências estão matriculadas desde a Educação Infantil até o Ensino Superior, sendo que 1.181.276 estudantes em escolas de educação básica ${ }^{3}$ e, 43.633 na educação superior ${ }^{4}$. O Gráfico 1 mostra a evolução das matrículas especificamente neste último nível de ensino, foco dessa pesquisa:

Gráfico 1: Evolução das matrículas de alunos com deficiência no ensino superior.

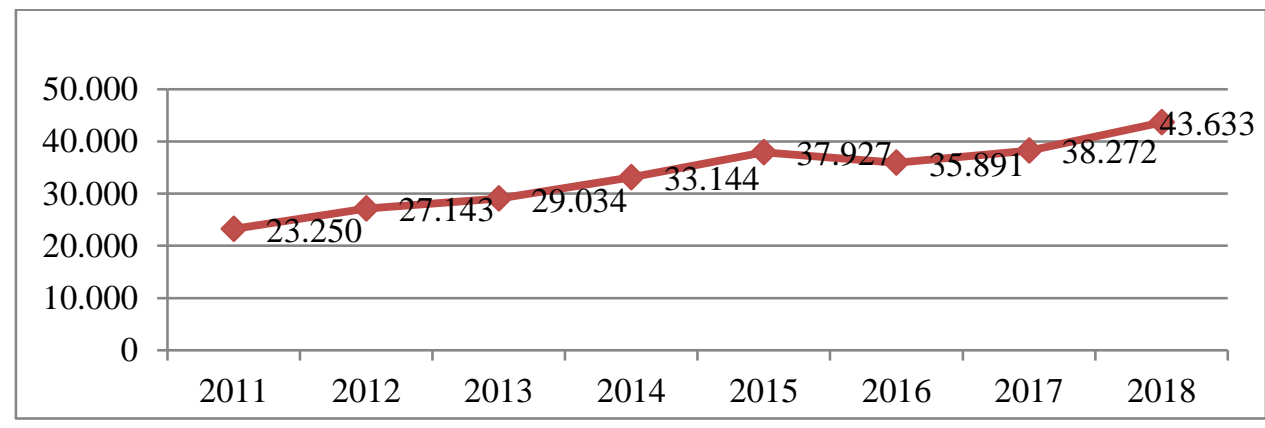

Fonte: INEP/2018

Na educação básica, o total das matrículas se dá, predominantemente, em escolas públicas: $992.084(83,9 \%)$ contra $188.192(16 \%)$ em escolas privadas. Essa distribuição é invertida no

\footnotetext{
${ }^{3}$ http://portal.inep.gov.br/web/guest/sinopses-estatisticas-da-educacao-basica

${ }^{4}$ http://portal.inep.gov.br/web/guest/sinopses-estatisticas-da-educacao-superior
} 
Ensino Superior, no qual predominam as matrículas em instituições privadas: 27.048 (61,9\%) para 16.585 (38\%) em instituições públicas.

É relevante, nesse contexto, destacar que a distinção de matrículas de pessoas com deficiência no ensino superior, só foi incluída, no Censo/Inep, a partir de 2011, sendo que, nesses 07 anos, o crescimento desse segmento, ultrapassou 40\% de matrículas, de 23.250 em 2011 para 43.633 em 2018, de acordo com o Censo da Educação Superior, MEC/INEP/2011 - 2018.

O Censo da Educação Superior não elenca a instituição ofertante, apenas a Rede de Ensino, então, é importante que haja uma contextualização que também pode ser um alerta para que o Censo do Ensino Superior discrimine as instituições ofertantes em cada Unidade de Federação. Merecem registros algumas situações sobre a distribuição das matrículas da Educação Especial no Ensino Superior, conforme o Censo/Inep/2018:

- Nas regiões Norte e Nordeste, nas matrículas totais, predominam as instituições públicas (61,7\%), embora Rondônia, Amazonas e Amapá, no Norte e Bahia, no Nordeste tenham números maiores nos estabelecimentos privados.

- Nas regiões Sudeste, Sul e Centro-Oeste, a grande maioria das matrículas está na esfera privada de ensino superior - 72,8\% ou, 21.797 das 29.915 matrículas registradas, somando-se as três regiões. Na região Sul, o Paraná tem o menor número de matrículas (176) em estabelecimentos federais de educação superior, ficando atrás apenas de Roraima (144) e Amapá (88) em âmbito nacional. O Mato Grosso do Sul é o único estado, fora do eixo Norte/Nordeste a ter maior número de matrículas públicas.

\section{OS INSTITUTOS FEDERAIS E A EDUCAÇÃO ESPECIAL}

Em 29 de dezembro de 2008, com a sanção da Lei $N^{\circ}$ 11.892/08, que instituiu a Rede Federal, 31 Centros Federais de Educação Tecnológica (CEFETs), 75 Unidades Descentralizadas de Ensino (UNEDs), 39 Escolas Agrotécnicas, 07 Escolas Técnicas Federais e 08 escolas vinculadas a universidades deixaram de existir para formar os Institutos Federais de Educação, Ciência e Tecnologia.

Atualmente, existem 38 Institutos Federais de Educação - IF, mais o Colégio Pedro II ${ }^{5}$, que juntos somam um total de 611 campi, distribuídos em todos os estados brasileiros.

Com essa expansão, os Institutos Federais tiveram que criar suas normas internas, apresentando o perfil da instituição, suas atividades de ensino, pesquisa e extensão, oferecendo

\footnotetext{
${ }^{5}$ Integrado à Rede Federal de Educação Profissional, Científica e Tecnológica nos termos da Lei no 11.892 , de 29 de dezembro de 2008, com a redação dada pela Lei n ${ }^{\circ} 12.677$, de 25 de junho de 2012. Para efeito de incidência das disposições normativas acerca da regulação, da avaliação e da supervisão da instituição e dos cursos de educação superior, o CPII é equiparado aos Institutos Federais (PDI, p.24)
} 
uma visão de presente e futuro (Muriel, 2006), incluídas as demandas relativas "às diferentes modalidades de ensino" (art. $2^{\circ}$ da Lei) exigindo, portanto, uma ressignificação do potencial formativo dos Institutos.

Essa ressignificação, minimamente, deverá estar configurada no Plano de Desenvolvimento Institucional - PDI, elaborado autonomamente por cada Instituto, de caráter plurianual e publicado por Resolução aprovada no respectivo Conselho Superior.

Para Rocha (2016), as iniciativas individualizadas de cada instituto deixam evidente a falta de uma institucionalidade nas ações voltadas à oferta de educação especial a ao atendimento das especificidades dos estudantes.

É, portanto, no PDI que se dá a continuidade da pesquisa sobre a Educação Especial nos IFs, iniciando pelo período de vigência, cujo resultado pode ser configurado em quatro situações: Sem Informação; Aprovado (pelo respectivo Conselho); Em Construção e em Consulta Pública, conforme Quadro 1:

Quadro 1: Levantamento da vigência/situação dos Planos de Desenvolvimento Institucional dos Institutos Federais de Educação.

\begin{tabular}{|c|c|c|c|}
\hline Região & Instituto Federal & Vigência Definida & Situação \\
\hline \multirow[t]{7}{*}{$\mathrm{NO}$} & IF do Acre - IFAC & $2014-2018$ & Sem Informação \\
\hline & IF do Amazonas - IFAM & $2019-2023$ & Consulta Pública \\
\hline & IF do Amapá - IFAP & $2019-2023$ & Aprovado \\
\hline & IF do Pará- IFPA & $2019-2023$ & Em Construção \\
\hline & IF de Rondônia - IFRO & $2018-2022$ & Aprovado \\
\hline & IF de Roraima - IFRR & $2019-2023$ & Aprovado \\
\hline & IF de Tocantins - IFTO & $2020-2024$ & Em Construção \\
\hline \multirow[t]{11}{*}{$\mathrm{NE}$} & IF de Alagoas - IFAL & $2019-2023$ & Aprovado \\
\hline & IF da Bahia - IFBA & $2015-2019$ & Sem Informação \\
\hline & IF Baiano - IF Baiano & $2020-2024$ & Em Construção \\
\hline & IF do Ceará - IFCE & $2019-2023$ & Em Construção \\
\hline & IF do Maranhão - IFMA & $2019-2023$ & Em Construção \\
\hline & IF da Paraíba - IFPB & $2020-2024$ & Em Construção \\
\hline & IF de Pernambuco - IFPE & $2014-2018$ & Sem Informação \\
\hline & IF do Sertão Pernambucano - IF Sertão & $2019-2023$ & Aprovado \\
\hline & IF do Piauí - IFPI & 2020-2024 & Em Construção \\
\hline & IF do Rio Grande do Norte - IFRN & $2019-2023$ & Em Construção \\
\hline & IF de Sergipe - IFSE & $2020-2024$ & Em Construção \\
\hline \multirow[t]{4}{*}{ SE } & IF do Espírito Santo - IFES & 2014-2019 & Sem Informação \\
\hline & IF de Minas Gerais - IFMG & $2019-2023$ & Aprovado \\
\hline & IF do Triângulo Mineiro - IFTM & $2019-2023$ & Aprovado \\
\hline & IF do Norte de Minas - IF Norte Minas & $2019-2023$ & Aprovado \\
\hline
\end{tabular}




\begin{tabular}{|c|c|c|c|}
\hline & IF do Sul de Minas - IF Sul Minas & $2019-2023$ & Aprovado \\
\hline & IF do Sudeste de Minas - IF Sudeste & $2020-2024$ & Em Construção \\
\hline & IF do Rio de Janeiro - IFRJ & $2014-2018$ & Sem Informação \\
\hline & IF Fluminense - IFF & $2018-2022$ & Aprovado \\
\hline & Colégio Pedro II - CPII & $2019-2023$ & Aprovado \\
\hline & IF de São Paulo & $2019-2023$ & Aprovado \\
\hline $\mathrm{S}$ & IF do Paraná & $2019-2023$ & Aprovado \\
\hline & IF do Rio Grande do Sul - IFRGS & $2019-2023$ & Aprovado \\
\hline & IF Sul Rio-grandense - IFSul & $2020-2024$ & Consulta Pública \\
\hline & IF Farroupilha - IFFar & $2019-2026$ & Aprovado \\
\hline & IF de Santa Catarina - IFSC & $2020-2024$ & Consulta Pública \\
\hline & IF Catarinense - IFC & $2019-2023$ & Aprovado \\
\hline $\mathrm{CO}$ & IF de Brasília - IFB & $2019-2023$ & Aprovado \\
\hline & IF de Goiás - IFG & $2019-2023$ & Aprovado \\
\hline & IF Goiano - IF Goiano & $2019-2023$ & Aprovado \\
\hline & IF do Mato Grosso do Sul - IFMS & $2019-2023$ & Aprovado \\
\hline & IF do Mato Grosso - IFMT & $2019-2023$ & Aprovado \\
\hline
\end{tabular}

Fonte: Site de cada Instituto Federal, consultado pelos autores entre fev./mar. 2020.

A sistematização do levantamento considerou a organização regional no intuito de facilitar a visualização, bem como para contextualizar as regiões em função das escolhas que serão feitas, para analisar a situação da Educação Especial nos Institutos Federais.

A primeira incursão se deu nos sumários dos Planos de Desenvolvimento Institucional, visando localizar onde foi inserida a Educação Especial, enquanto modalidade de ensino e, para nossa surpresa, em nenhum PDI há essa discriminação, embora a história da inclusão das pessoas com deficiência nos IFs tenha começado a ser escrita de forma efetiva com a criação do programa TECNEP (2000), que propunha o atendimento das pessoas com deficiência e outras necessidades educativas especiais, na Rede de Educação Tecnológica (SANTOS, 2011, p. 57).

Com esse contexto em mente, passamos à seleção de 05 Planos, entre os que já estão com aprovação do respectivo Conselho Superior, por região, levando em conta: a) o maior número de alunos com deficiência matriculados, no Estado $^{6}$, nas Instituições Federais ${ }^{7}$, conforme dados disponibilizados pelo INEP quanto ao Censo Escolar de 2018 e/ou, b) alguma especificidade que destaque aquele IF dos demais, quando o Estado tiver mais de um Instituto com PDI aprovado.

Dessa forma, na Região Norte, teríamos Amapá com 88 matrículas, Roraima com 144 e Rondônia com 201. No Nordeste, Alagoas com 745 e Pernambuco com 350 matrículas. Sudeste,

\footnotetext{
${ }^{6}$ O Censo não especifica a Instituição.

${ }^{7}$ Esse recorte se deve ao fato de que nem todos os Estados possuem Instituições estaduais e/ou municipais de Ensino Superior.
} 
Minas tem 1.231 matrículas, Rio de Janeiro com 443 e São Paulo, 530. Na Região Sul, Paraná tem 170, Rio Grande do Sul, 995 e Santa Catarina, 331 matriculados. No Centro-Oeste, o Distrito Federal soma 209 matrículas, Goiás, 394, Mato Grosso do Sul, 581 e Mato Grosso, 233.

Nas Regiões Norte, Nordeste e Centro-Oeste as escolhas foram simplificadas pelo número de matrículas em estados com um único Instituto, destacando, para análise, o IFRO, IFAL e IFMS, respectivamente. Na Região Sudeste, optamos por analisar o PDI do Colégio Pedro II por ser a única instituição federal que oferta desde a Educação Infantil (e que está construindo um NAPNE ${ }^{8}$ específico para esse segmento), até a pós-graduação. Na Região Sul, a escolha recaiu no Rio Grande do Sul, que tem o maior número de matrículas e, no IFFAR que, diferentemente dos demais Institutos, tem um PDI para 08 anos.

\section{ANÁLISE DOS PLANOS DE DESENVOLVIMENTO INSTITUCIONAL SELECIONADOS POR REGIÃO.}

\section{Norte: Instituto Federal de Rondônia - IFRO9}

O IFRO é resultado da integração, em 2008, da Escola Técnica Federal de Rondônia, à época em fase de implantação, e da Escola Agrotécnica Federal de Colorado do Oeste, originando uma Reitoria, e a previsão de 5 campi. Atualmente, o Instituto Federal de Rondônia possui 09 (nove) campi presenciais, em municípios estratégicos do estado, além de 199 polos de EaD, 23 em parceria com os 22 municípios do Estado e 176 em parceria com o Governo do Estado de Rondônia.

A primeira referência a pessoas com necessidades especiais no PDI do Instituto está na inclusão de "Fortalecimento dos Núcleos de Atendimento às Pessoas com Necessidades Específicas" (NAPNE), no portfólio de Projetos. Na parte em que traz a Organização Administrativa do IFRO, novamente há referência ao NAPNE, informando ser órgão de assessoramento e encontra-se ligado à Reitoria, à Pró-Reitoria de Ensino e, em cada campus, diretamente à Diretoria de Ensino.

Nas Políticas de Atendimento ao Discente, logo após a descrição da finalidade do NAPNE, informa que o NAPNE ainda está em implantação, no âmbito do Instituto Federal de Educação, Ciência e Tecnologia de Rondônia, e suas políticas, devidamente efetivadas por meio de planos, programas e projetos, ainda estão sendo desenvolvidas e deverão ser concretizadas até 2022, em

\footnotetext{
${ }^{8}$ NAPNE - Núcleo de Atendimento às Pessoas com Necessidades Específicas.

${ }^{9}$ PDI aprovado pela Resolução no 29/CONSUP/IFRO de 26/04/2018.
} 
parte ou no todo, quando do término das ações previstas no Plano de Desenvolvimento Institucional.

O IFRO também define, no item Estímulos à Permanência (Programa de Nivelamento, Atendimento Psicopedagógico), ações a serem desenvolvidas por setores específicos no âmbito do Plano Estratégico de Permanência e Êxito, que visa à diminuição dos níveis de evasão e de retenção aos índices minimamente aceitáveis. Ao NAPNE cabe, entre outras, a criação do Grupo de Estudo e Pesquisa em Inclusão - GEPI.

Por último, quanto à infraestrutura física, está o Plano de Promoção de Acessibilidade e de Atendimento Diferenciado a Pessoas com Necessidades Específicas, que inclui Acessibilidade Física (construção, adequação e reforma) e Acessibilidade Educacional, com a proposta de criar um manual padronizado dos ambientes do Instituto Federal de Rondônia, elaborando, a partir deste, um diagnóstico de acessibilidade física que forneça o suporte adequado na elaboração de novos projetos de infraestrutura de acesso aos campi.

\section{Nordeste: Instituto Federal de Alagoas - IFAL ${ }^{10}$.}

A criação do Instituto Federal de Alagoas, em 2008, integrou a Escola Agrotécnica Federal de Satuba, criado como Patronato Agrícola de Alagoas, em 1911, e o Centro Federal de Educação Tecnológica. Atualmente, o IFAL possui 16 campi distribuídos pelo Estado, além da Reitoria, localizada em Maceió.

Logo de início, o Projeto Político-Pedagógico (PPP) informa que as políticas de ensino se constituem em desafios teórico, conceitual e metodológico. As Diretrizes Gerais do Instituto enfatizam a necessidade de garantia de padrões de infraestrutura física e de equipamentos dos Campi e dos Polos do IFAL, inclusive, relativos à acessibilidade de pessoas com deficiências, ampliando, adequando e modernizando laboratórios, salas de aulas, bibliotecas e demais espaços físicos. Isso significa promover o acesso das minorias ao IFAL, contemplando as peculiaridades das pessoas com deficiência e com necessidades educacionais específicas.

Observa-se que as políticas estudantis devem ser direcionadas à permanência com qualidade dos estudantes, na perspectiva da inclusão social. Neste Instituto, existem diversos dispositivos que orientam a atuação de programas e apoio para a educação inclusiva, como: o Plano Estratégico Institucional de Permanência e Êxito (PEIPE); o Fórum Permanente de Assistência Estudantil (FORPAE); os núcleos de ações afirmativas (NAPNE e NEABI) e a Política de Assistência Estudantil (PAE), que compreende, ainda, a educação inclusiva e o protagonismo e organização estudantil. 
Nas políticas estudantis, especificamente com relação à educação inclusiva, o IFAL define como objetivo das políticas de inclusão e acessibilidade a garantia de processos educativos que possibilitem condições equânimes, que abarquem desde o ingresso até a conclusão do curso, tendo como princípio o compromisso com a inclusão e com a acessibilidade, e, entre as diretrizes, a acessibilidade na arquitetura, nos transportes, nos mobiliários, equipamentos, nas comunicações, nos recursos didáticos e pedagógicos. Entre os Programas Universais, o destaque vai para o PAENE - Programa de Assistência às/aos Estudantes com Necessidades Específicas, vinculado ao NAPNE de cada Campus.

Sobre as Políticas de Gestão, destaca-se a Promoção da acessibilidade, que significa atender a toda comunidade, usuários e servidores, incluindo o atendimento prioritário, imediato e diferenciado às pessoas portadoras de necessidades educacionais especiais ou com mobilidade reduzida, para utilização, com segurança e autonomia, total ou assistida, dos espaços, mobiliários e equipamentos urbanos, das edificações, dos serviços de transporte, dos dispositivos, sistemas e meios de comunicação e informação, permitindo a inclusão e o desenvolvimento das atividades fins da Instituição.

\section{Sudeste: Colégio Pedro II - CPII ${ }^{11}$.}

Fundado em 02 de dezembro de 1837, o Colégio Pedro II foi equiparado aos Institutos Federais de Educação, Ciência e Tecnologia com a sanção da lei 12.677/12 e conta, atualmente, com 13.119 alunos matriculados nos 14 campi, sendo 12 no município do Rio de Janeiro, 01 em Niterói e 01 em Duque de Caxias, e no Centro de Referência em Educação Infantil - CREIR, localizado em Realengo.

Na Pró-Reitoria de Ensino - PROEN, onde fica a Coordenação de Cursos de Educação Especial, um dos objetivos específicos prevê reforçar e universalizar a cultura da inclusão, tornando natural a presença de pessoas com necessidades específicas. No CPII, o NAPNE, que engloba os espaços-tempos da Sala de Recursos Multifuncionais e do Laboratório de Aprendizagem, está localizado nos espaços de extensão e complementação pedagógica.

Em duas, das três Diretrizes Estruturantes do Planejamento Institucional, há objetivos estratégicos relacionados à inclusão e acessibilidade, são elas: Acadêmica e Pedagógica, que visa proporcionar o acompanhamento adequado aos discentes com necessidades específicas; e a Gestão e Desenvolvimento, que visa adequar os ambientes pedagógicos e administrativos no sentido de promover o acesso, a circulação e permanência de pessoas com necessidades especiais

${ }^{11}$ PDI aprovado pela Resolução no 147 de 11/09/2019. 
ou mobilidade reduzida. Também, no Plano de Metas (2019-2023), estão previstas obras de acessibilidade em diversos espaços e campi, a depender de liberação de recursos e licitação.

\subsection{Educação Infantil no CPII.}

Em dezembro de 2013, foi criada a Unidade de Educação Infantil Realengo para cumprir, exclusivamente, essa etapa do ensino, iniciada um ano antes no Campus Realengo I. No ano de 2016, foi transformada em Centro de Referência em Educação Infantil Realengo (CREIR), com administração independente do Campus Realengo I, vinculada diretamente à Reitoria.

Para além da inclusão da educação infantil do Colégio, após sua integração à Rede Federal de Educação Profissional, Científica e Tecnológica, o que se destaca aqui é a criação de um NAPNE exclusivo para essa etapa de ensino. O Núcleo na Educação Infantil do Colégio Pedro II começou a ser criado em junho de 2017, sob a orientação da Coordenação Setorial do CREIR e NAPNE Geral/ Diretoria de Assuntos Estudantis - DAE. A Coordenadora do NAPNE/CREIR destaca que "o fato de que a EI ainda não tinha um núcleo voltado às crianças com necessidades educacionais específicas, não significou que estas não eram atendidas em suas singularidades" (FERREIRA e KELMER, p. 07, 2019).

No entanto, a criação de um NAPNE específico, considerando as especificidades da faixa etária atendida (3 a 6 anos), com todas as exigências de formação dos profissionais e as competências definidas pelo Atendimento Educacional Especializado (AEE), estaria inovando em respeito ao atendimento em educação especial desde a educação infantil, que no CPII, caracterizase também pela bidocência, que corresponde a ter dois professores por turma.

\section{Sul: Instituto Federal Farroupilha - IFFAR ${ }^{12}$.}

O Instituto Federal de Educação, Ciência e Tecnologia Farroupilha - IFFAR nasceu, em 2008, da integração entre 4 instituições: o Centro Federal de Educação Tecnológica de São Vicente do Sul, a unidade Descentralizada de Júlio de Castilhos, a Escola Agrotécnica Federal de Alegrete e a unidade Descentralizada de Ensino de Santo Augusto, que anteriormente pertencia ao Centro Federal de Educação Tecnológica de Bento Gonçalves.

As ações e propostas para atendimento de estudantes com necessidades específicas do PDI 2019-2026, do IFFAR, iniciam pela meta de tornar 100\% da estrutura física condizente com as questões de acessibilidade e inclusão. É importante destacar que o IFFAR conta, em todos os campi e na Reitoria, com a Coordenação de Ações Inclusivas ${ }^{13}$ (CAI), cujas ações e projetos

\footnotetext{
${ }^{12}$ PDI aprovado pela Resolução CONSUP n ${ }^{\circ} 009$ de 26/04/2019
}

${ }^{13}$ Resolução CONSUP no $15 / 2014$ 
buscam garantir condições e oportunidades educacionais igualitárias e correta execução da Política de Diversidade e Inclusão da entidade.

A institucionalização das ações do IFFAR ensejou uma série de documentos, entre os quais citamos Regimento da Coordenação de Ações Inclusivas; Política de Diversidade e Inclusão; Regulamento do Núcleo de Elaboração e Adaptação de Materiais Didático/Pedagógico; Regulamento de Atendimento Educacional Especializado; Política de Ações Afirmativas de Inclusão Socioeconômica, Étnico-Racial e para PcD; Manual de Procedimentos Acessíveis para Processos Seletivos; Regulamento de Terminalidade Específica e Plano de Acessibilidade Arquitetônica e Estrutural.

Entre os princípios da Política de Diversidade e Inclusão do IFFAR, presentes nos citados documentos, são mencionados o convívio e respeito às diversidades étnica, cultural, social, sexual, de gênero, de crença, de necessidades específicas ou outras características individuais, coletivas e sociais, e promoção à acessibilidade.

Destaque para dois dos Núcleos Inclusivos: Núcleo de Apoio às Pessoas com Necessidades Específicas (NAPNE), já implementado em cada um dos campi e o Núcleo de Elaboração e Adaptação de Materiais Didáticos/Pedagógicos do IFFAR (NEAMA), cuja função é dar suporte a todos os campi na elaboração de materiais didáticos/pedagógicos adaptados. $\mathrm{O}$ NEAMA está alocado na Reitoria, e inclui revisores de Texto Braille, tradutores intérpretes de Libras e demais profissionais necessários para produção e adaptação de materiais didáticopedagógicos.

Com relação à infraestrutura, o PDI do IFFAR destaca que a instituição prioriza a inclusão entre alunos, professores, funcionários e a comunidade em geral, melhorando constantemente a infraestrutura de acessibilidade com a inclusão de projetos de acessibilidade para todas as obras novas e reformas.

\section{Centro-Oeste: Instituto Federal de Mato Grosso do Sul - IFMS $^{14}$.}

A Lei $n^{\circ} 11.534$, de 25 de outubro de 2007, criou 02 escolas técnicas e agrotécnicas federais em Mato Grosso do Sul, nas cidades de Campo Grande e Nova Andradina. No ano seguinte, com a reestruturação da Rede Federal, foi criado o IFMS prevendo a instalação dos campi nos mesmos municípios. Com os projetos de expansão da Rede Federal, que se seguiram, o IFMS possui atualmente 10 Campi, que atendem todas as regiões do estado.

As questões relativas à inclusão, acessibilidade e de atendimento diferenciado a pessoas com deficiência, no PDI, são abordadas no item 'Políticas de Gestão', que cita o NAPNE como

${ }^{14}$ PDI aprovado pela Resolução n ${ }^{\circ}$ 067/CONSUP de 13/12/2018. 
uma prática de inclusão dentro da promoção dos direitos humanos, tendo como finalidades propor normas de inclusão a serem praticadas na instituição, promover a temática da acessibilidade em todas as suas acepções, bem como prestar atendimento aos estudantes com necessidades educacionais específicas.

Considerando a inclusão social de todos os grupos um desafio institucional, o IFMS planeja instituir, durante a vigência do atual PDI, a Política de Responsabilidade Social, que incluirá, entre outras ações, o Plano de Promoção da Acessibilidade e de Atendimento Diferenciado a Pessoas com Deficiência ou Mobilidade Reduzida. Entre as ações desenvolvidas pelo Instituto como parte da responsabilidade Social, incluem-se o NAPNE e a promoção de acessibilidade comunicacional, arquitetônica, atitudinal, metodológica, entre outras, para estudantes, servidores e comunidade externa, articulada pela Coordenação de Inclusão e Diversidade.

No Plano de Metas, o macro objetivo intenta promover a inclusão social, acessibilidade e respeito à diversidade, tendo entre as metas adequar a infraestrutura física e tecnológica para garantia da acessibilidade e promoção do esporte, elaborar e implementar o Plano de Promoção da Acessibilidade e de Atendimento Diferenciado a Pessoas com Deficiência ou Mobilidade Reduzida e implantar o uso de tecnologias em processos educacionais para facilitar a acessibilidade e o atendimento diferenciado a pessoas com deficiência ou mobilidade reduzida.

Entre as políticas de atendimento aos discentes, as ações de inclusão e diversidade, visam incluir os estudantes nas atividades institucionais, objetivando oportunidades iguais de acesso e permanência às pessoas com necessidades educacionais específicas e também contemplam diferenças de classe social, gênero, idade e origem étnica. O NAPNE é uma dessas ações. Na descrição da Infraestrutura do Instituto, o PDI /IFMS foi o único a incluir as vagas de Estacionamento para $\mathrm{PcD}$, disponíveis em cada campus.

\section{CONSIDERAÇÕES FINAIS}

Os resultados apresentados neste capítulo não permitem 'fechar' questão em torno dos itens destacados. Antes, pressupõem uma série de condicionalidades, propósitos e intencionalidades que indicam a busca por promover inclusão, autonomia, melhoria da qualidade de vida, inserção social e, sobretudo, o acesso à educação com permanência e sucesso na aprendizagem. Ou seja, tudo o que está garantido sob o ponto de vista do direito à educação, em termos legais, porém em estágios diferentes nas condições de oferta, conforme o PDI de cada um dos cinco Institutos. 
É preciso reconhecer que avançamos conceitualmente, como também é urgente reconhecer que a prática precisa incorporar essas discussões e avanços para além da acessibilidade arquitetônica, oferecendo condições para que os estudantes com deficiência e/ou com necessidades específicas, sintam-se não somente incluídos, como respeitados nas suas especificidades.

Se a inclusão é um processo ainda não consolidado em sua totalidade, a análise dos Planos de Desenvolvimento Institucional demonstra que os espaços têm sido ocupados e ampliados com políticas e ações que definem novos rumos para a educação especial, apesar do contingenciamento financeiro e da redução das políticas de educação especial no último ano.

\section{REFERÊNCIAS}

COLÉGIO PEDRO II- CPII. Plano de Desenvolvimento Institucional. Disponível em: https://www.cp2.g12.br/. Acesso: 10/02/2020.

FERREIRA, Cintia Tavares; KELMAN Celeste Azulay. A construção de um NAPNE na Educação Infantil do Colégio Pedro II. In: WESSELOVICZ, Glaucia; CAZINI Janaína (Orgs.) Diálogos sobre Inclusão. Atena Editora, 2019. Disponível em: https://pt.slideshare.net/Antonella0611/dilogos-sobre-incluso-2 Acesso: 06/02/2020

INSTITUTO NACIONAL DE ESTUDOS E PESQUISAS EDUCACIONAIS ANÍSIO TEIXEIRA/INEP - Sinopse Estatística da Educação Superior 2011 a 2018. Brasília: Inep, 2019. Disponível em: http://portal.inep.gov.br/basica-censo-escolar-sinopse-sinopse Acesso em: 02/02/2020.

Sinopse Estatística da Educação Básica 2018. Brasília: Inep, 2019. Disponível em: $\overline{\mathrm{http}} / / /$ portal.inep.gov.br/sinopses-estatisticas-da-ediucacao-basica Acesso: 02/02/2020.

IBGE. Metodologia do Centro Demográfico 2000. Rio de Janeiro: IBGE, 2003. (Série Relatórios Metodológicos 25). Disponível em: http://goo.gl/UvlwF. Acesso: 08/02/2020.

INSTITUTO FEDERAL DE ALAGOAS - IFAL. Plano de Desenvolvimento Institucional. Disponível em: https://www2.ifal.edu.br/. Acesso: 10/02/2020.

INSTITUTO FEDERAL FARROUPILHA - IFFAR. Plano de Desenvolvimento Institucional. 2019-2023. Disponível em: https://www.iffarroupilha.edu.br/. Acesso: 11/02/2020.

INSTITUTO FEDERAL DO MATO GROSSO DO SUL - IFMS. Plano de Desenvolvimento Institucional. Disponível em: https://www.ifms.edu.br/. Acesso: 11/02/2020.

INSTITUTO FEDERAL DE RONDÔNIA - IFRO. Plano de Desenvolvimento Institucional. Disponível em: https://portal.ifro.edu.br/. Acesso: 10/02/2020.

MARCELINO, M. A. Capacitação de multiplicadores. INSS, Brasília: 2013.

Disponível em: https://peritomed.files.wordpress.com/2013/12/1-a-evolue7e3o-do-conceito-dedeficieancia-capacitae7e3o-lei-compl-142-2013.pdf. Acesso: 08/02/2020. 
MAZZOTTA, M. J. S. Educação especial no Brasil: história e políticas públicas. 5 ed. São Paulo: Cortez, 2005.

MURIEL. R. Plano de Desenvolvimento Institucional - PDI - Análise do processo de implementação. Espírito Santo: Editora Hoper, 2006.

ROCHA, Vânia M. A educação especial nos institutos federais: o que dizem os Planos de Desenvolvimento Institucionais? 2016. Dissertação (Mestrado em Educação) - Universidade da Região de Joinville. Joinville, 2016.2 Disponível em: <https://www.univille.edu.br/account/mestradoedu/VirtualDisk.html/downloadDirect/1078176/ RO> Acesso: 12/02/2020.

SASSAKI, Romeu K. Inclusão: construindo uma sociedade para todos. Rio de janeiro: WVA editora, 1999.

SANTOS, Y. B. S. As políticas públicas de educação para a pessoa com deficiência: a proposta desenvolvida nos Institutos Federais de Educação, Ciência e Tecnologia. Dissertação (Mestrado em Educação) - Universidade Federal do Ceará, Fortaleza, 2011. Disponível em: http://www.repositorio.ufc.br/handle/riufc/3038 Acesso: 02/02/2020. 
Breno Trajano de Almeida é Mestre em Educação pela Universidade de São Paulo (USP). Foi Secretário de Educação da cidade de Aparecida-PB, Consultor Técnico no Ministério da Educação e do Programa das Nações Unidas para o Desenvolvimento (PNUD), Professor das redes estadual e municipal de São Paulo, e da Universidade Brasil. Atualmente, é Professor Efetivo do Instituto Federal do Rio Grande do Norte (IFRN). É pesquisador na área de Políticas Educacionais, com ênfase na Educação do Campo, Formação de Professores e Educação de Jovens e Adultos.

Currículo Lattes: http://lattes.cnpq.br/4028269006895230

Rosana de Oliveira Sá é Mestra em Formação de Professores pela Universidade Estadual da Paraíba (UEPB). Especialista em Língua Inglesa e Literatura Anglo-Americana e Graduada em Letras (habilitação em Português e Inglês) pela Universidade Federal da Paraíba (UFPB). Professora Efetiva do Instituto Federal de Educação, Ciência e Tecnologia da Paraíba (IFPB). Seus interesses de pesquisa incluem Português e Inglês para Fins Específicos na Formação Tecnológica em geral e no PROEJA; Formação Inicial e Continuada de Professores; Metodologias e Ensino de Línguas; Letramento e Educação Inclusiva.

Currículo Lattes: http://lattes.cnpq.br/5547683863411926 
Andrezza Maria Batista do Nascimento Tavares é Doutora e Mestra em Ciências da Educação pela UFRN. Graduada em Pedagogia e em Jornalismo. Pós-Graduada em Psicopedagogia Clínica. Professora do Instituto Federal de Educação, Ciência e Tecnologia do Rio Grande do Norte (IFRN), onde realiza atividades de ensino, pesquisa e extensão. No IFRN, atua como Professora do Programa de Pós-Graduação Acadêmica (PPGEP/IFRN), do Mestrado Profissional em Ensino de Física (MNPEF/IFRN) e dos Cursos Superiores de Graduação.

Currículo Lattes: http://lattes.cnpq.br/5187018279016366

Artur Fabiano Araújo de Albuquerque é Mestre em Música - ênfase em Educação Musical - pela Universidade Federal da Paraíba - UFPB. Licenciado em Música pela Universidade Federal de Pernambuco - UFPE. É Professor de Artes-Música do Instituto Federal do Rio Grande do Norte - IFRN. Coordenador de Pesquisa e Inovação do IFRN Campus Nova Cruz. Pesquisador do Grupo de Pesquisa "Formação e Atuação Profissional de Professores de Música" (UFPE).

Currículo Lattes: http://lattes.cnpq.br/2137863532516046

Cristina Régia Barreto Moreira é Mestra em Matemática pela Universidade Federal Rural do Semi-Árido e Sociedade Brasileira de Matemática. Foi Professora e Coordenadora Pedagógica da rede estadual do Ceará, Colaboradora do Banco Nacional de Itens/INEP. É pesquisadora na área de Avaliação Educacional, com ênfase no ensino de Matemática. Atualmente, é professora do Instituto Federal de Educação, Ciência e Tecnologia do Rio Grande do Norte (IFRN).

Currículo Lattes: http://lattes.cnpq.br/7499826582169336

Edna Oliveira da Paz é Graduada em Direito e em Pedagogia pela Universidade Federal de Campina Grande. Especialista em Psicopedagogia pela Faculdade Integrada de Patos; em Atendimento Educacional Especializado pela Universidade Federal do Ceará; e em Educação de Jovens e Adultos pela Faculdade Entre Rios. Atualmente, é professora do Município de Santa Cruz/PB e formadora da Sincroniza Educação. Tem experiência na área de Educação, como Dirigente Municipal de Educação (Aparecida/PB), bem como Consultora Técnica no Ministério da Educação.

Currículo Lattes: http://lattes.cnpq.br/7881416580042884

Fernanda Oliveira Costa Gomes é Doutora em Educação: História, Política, Sociedade pela PUC-SP. Mestra em Educação: História, Política, Sociedade pela PUC-SP. Especialista em Psicopedagogia e Graduada em Pedagogia. Professora atuante na rede pública municipal da cidade de São Paulo-SP. Professora em cursos de Pedagogia e outras licenciaturas em Universidades particulares na cidade de São Paulo-SP.

Currículo Lattes: http://lattes.cnpq.br/8044154037224066

Francisco José Pires é Doutor e Mestre em Integração da América Latina pela Universidade de São Paulo (USP). Possui as seguintes Especializações: Arte, Educação e Terapia; Mídias na Educação; Educação Multicultural, Estética e História da Arte; e Planejamento, Implementação e Gestão da Educação a Distância. É Jornalista, Pedagogo, Geógrafo e Arte Educador. É pesquisador nas áreas de Políticas Públicas em Educação e Trabalho, Políticas, Avaliação e Gestão no Ensino Superior.

Currículo Lattes: http://lattes.cnpq.br/5936955292373541

Francisco Marcos da Silva Figueiredo é Graduado em Enfermagem, Especialista em Auditoria em Saúde e mestrando em Saúde Coletiva da Universidade Católica de Santos (UNISANTOS). Atua como Supervisor Pedagógico e Professor em Enfermagem no Instituto Tecnológico da Paraíba - ITEC Mais. É docente do Programa de Extensão Universitária da 
Faculdade Kúrios, nas áreas correspondentes ao ensino e educação nas vertentes de saúde e psico humana.

Currículo Lattes: http://lattes.cnpq.br/5202446856364209

Hellyegenes de Oliveira é Pedagogo pelo Instituto Superior de Educação de Cajazeiras. Especialista em Psicopedagogia pelo Centro Universitário de Patos, e em Educação de Jovens e Adultos pela Universidade Federal de Campina Grande. Mestrando em Educação pela Universidade do Sul de Santa Catarina (Unisul). Atualmente, é Gestor Escolar na rede municipal de ensino de Sousa/PB, professor na EJA em Ipaumirim/CE e professor no Núcleo de Extensão da Faculdade Kúrios.

Currículo Lattes: http://lattes.cnpq.br/1060183252356084

Karina de Oliveira Lima possui graduação em Pedagogia pela Universidade Federal do Rio Grande do Norte. É Mestra em Educação pela Universidade Federal do Rio Grande do Norte e doutoranda em Educação pela mesma instituição. Tem experiência na área de Educação, com ênfase em Currículos Específicos para Níveis e Tipos de Educação. Foi coordenadora do Estágio Supervisionado e do Curso Superior de Licenciatura em Informática do IFRN. Atualmente, é docente EBTT do Instituto Federal de Educação, Ciência e Tecnologia do Rio Grande do Norte.

Currículo Lattes: http://lattes.cnpq.br/3109461311817694

Kleber Kroll de Azevedo Silva é Mestre em Ciência da Computação pela Universidade do Estado do Rio Grande do Norte (UERN). Atualmente, é professor do Instituto Federal de Educação, Ciência e Tecnologia do Rio Grande do Norte. Atua como coordenador do Programa Institucional de Bolsa de Iniciação à Docência (PIBID) no curso de Licenciatura em Informática. Desenvolve pesquisas em formação de professores e estudantes para a área de Computação. Currículo Lattes: http://lattes.cnpq.br/9431509714787669

Leonardo Rafael Medeiros é Biólogo e Mestre em Ecologia pela Universidade Federal do Rio Grande do Norte (UFRN). É pesquisador na área de Educação Inclusiva, Ensino de Ciências e Educação Ambiental. Já trabalhou no Instituto Federal do Ceará (IFCE) e, atualmente, é professor de biologia do Instituto Federal do Rio Grande do Norte (IFRN). Desde o início da carreira, atua no Núcleo de Atendimento às Pessoas com Necessidades Educacionais Específicas (NAPNE), no qual atualmente é coordenador. Currículo Lattes: http://lattes.cnpq.br/9979094205106340

Linduarte Pereira Rodrigues é Doutor em Linguística pela Universidade Federal da Paraíba (UFPB). Professor do Departamento de Letras e Artes e do Programa de Pós-Graduação em Formação de Professores da Universidade Estadual da Paraíba (UEPB - Campus I). Líder do grupo de pesquisa "Teorias do sentido: discursos e significação".

Currículo Lattes: http://lattes.cnpq.br/4347612151916121

Louize Gabriela Silva de Souza é Doutora e Mestra em Educação pela Universidade Federal do Rio Grande do Norte (UFRN). É pesquisadora do Grupo de Estudos da Complexidade (GRECOM/UFRN), com ênfase nos temas complexidade, educação e itinerários formativos. Foi professora da rede municipal de Natal e Coordenadora Pedagógica de uma escola estadual no Rio Grande do Norte. Atualmente, é docente do Instituto Federal de Educação, Ciência e Tecnologia do Rio Grande do Norte (IFRN). 
Currículo Lattes: http://lattes.cnpq.br/2335250717975703

Luciana Real Limeira é Mestra em Educação Musical pela Universidade Federal da Paraíba (UFPB). Especialista em Educação Musical e Licenciada em Música pela Escola de Música e Belas Artes do Paraná (EMBAP). Foi professora da Rede Municipal de Ensino de Olinda/PE e da Rede Estadual de Ensino do Estado da Paraíba. Atualmente, é professora do Instituto Federal do Rio Grande do Norte e regente do Coral Vale Vocalis da mesma instituição. Como cantora, participou de diversos encontros corais nacionais e internacionais.

Currículo Lattes: http://lattes.cnpq.br/7420749981245138

Maria José Rocha Lima é Mestre em Educação pela UFBA e doutoranda em Educação. Deputada Estadual da Bahia (1991-1999); professora do Ensino Superior; assessora para a área da Educação na Câmara dos Deputados (1999-2003), quando participou da elaboração da PEC112, que deu origem ao FUNDEB; assessora especial do Ministro da Educação (2003). Elaborou o Programa Angola Bem Alfabetizada, no continente africano (2006/2007). Agraciada com o Prêmio Darcy Ribeiro de Educação, na Câmara dos Deputados, e o Diploma Bertha Lutz, do Senado.

Currículo Lattes: http://lattes.cnpq.br/4151064080868357

Patrícia Lacerda de Carvalho é doutoranda e Mestra em Administração, pela Universidade Federal da Paraíba (UFPB). Especialista em Gestão de Pessoas e Coaching e em Gestão Financeira, pela Estratego. É pesquisadora com ênfase nas áreas de Gestão, Sustentabilidade e Finanças. Atuou no setor Administrativo da Secretaria da Educação do Estado da Paraíba. Atualmente, é professora Substituta da UFPB.

Currículo Lattes: http://lattes.cnpq.br/7723495864846018

Rebeca Sá do Nascimento Carrazzoni é doutoranda e Mestra pelo Programa de PósGraduação em Administração - PPGA UFPB na área de Marketing e Sociedade. É Professora de Administração Geral na Faculdade Três Marias - FTM. Atuou como Agente Local de Inovação do SEBRAE PE pelo Programa ALI. Pesquisa Marketing, Macromarketing, Gestão da Qualidade, Empreendedorismo e Gestão Organizacional.

Currículo Lattes: http://lattes.cnpq.br/1176671614574851

Roseli Trevisan Marques de Souza é Doutora em Educação pela Faculdade de Educação da Universidade de São Paulo (FE/USP). Mestra em Educação pela Universidade Nove de Julho. Especialista em Gestão Educacional pela Universidade de Campinas (UNICAMP). Produziu artigos sobre a relação escola e comunidade; educação escolar e educação social; e sobre a educação embasada nos ideais democráticos, envolvendo, nas produções, o conceito de formação cidadã.

Currículo Lattes: http://lattes.cnpq.br/4405070313693489

Tuesla Bezerra Santos é Graduada em Informática pelo Instituto Federal de Educação, Ciência e Tecnologia do Rio Grande do Norte. Participou da organização do I ENSOL - Encontro Nacional de Software Livre do Vale do Assú (2014), da III EXPOTEC - Exposição Científica, Tecnológica e Cultural (2016), além da criação e organização da I ENETEC - Encontro de Empreendedorismo e Tecnologia (2016).

Currículo Lattes: http://lattes.cnpq.br/6534038043306586 
A Faculdade Metropolitana Norte Riograndense (FAMEN) é credenciada pela Portaria $\mathbf{n}^{\mathbf{0}}$ 665/MEC, publicada no Diário Oficial da União em 22 de março de 2019. Entre as atividades vinculadas ao ensino superior, a Faculdade oferece serviços acadêmicos da EDITORA FAMEN que objetiva a difusão de conhecimento por meio de e-books, periódicos (revista científica e jornal eletrônico), anais de eventos e repositório institucional, sendo vinculada a Diretoria de Pesquisa da Faculdade.

A EDITORA FAMEN é especializada em publicar conhecimentos relacionados ao campo da educação e a áreas afins por meio de plataforma online. $\mathrm{O}$ endereço eletrônico para acessar as suas publicações e demais serviços acadêmicos é o www.editorafamen.com.br.

A EDITORA FAMEN realiza edição, difusão e distribuição de produções editoriais seguindo uma Política Editorial qualificada e baseada nas seguintes linhas: acadêmica, técnico-científica, produção didático-pedagógico, produção artístico-literária e cultura popular. 


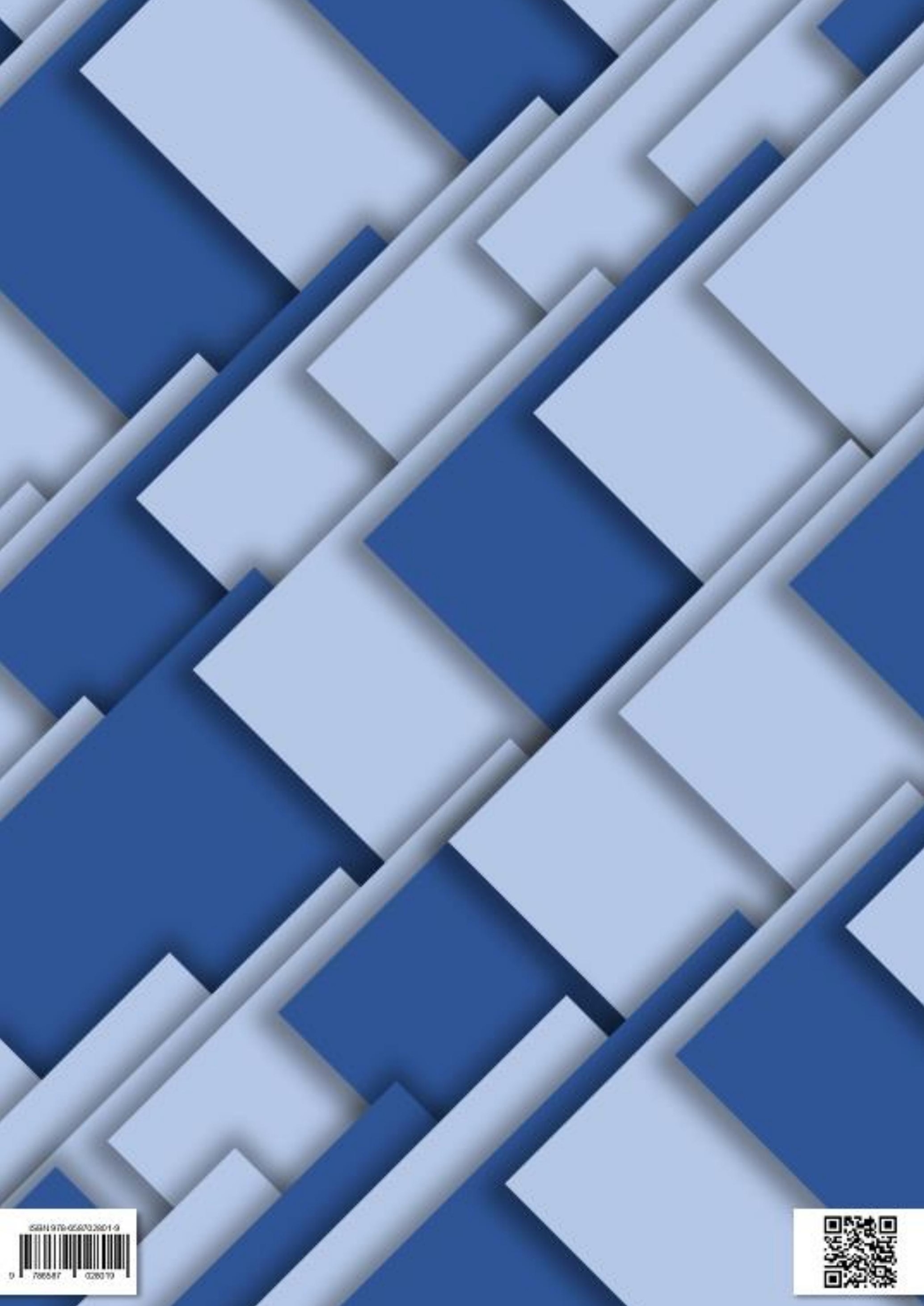

